Bot

Plora

C

Church, Arthur Henry

Introd.to the plant-life of the Oxford district.

Vol.1. 

BOTANICAL MEMOIRS. No. I3

\title{
INTRODUCTION TO THE PLANT-LIFE OF THE OXFORD DISTRICT
}

\author{
I. GENERAL REVIEW
}

$$
\text { By }
$$

A. H. CHURCH, M.A.

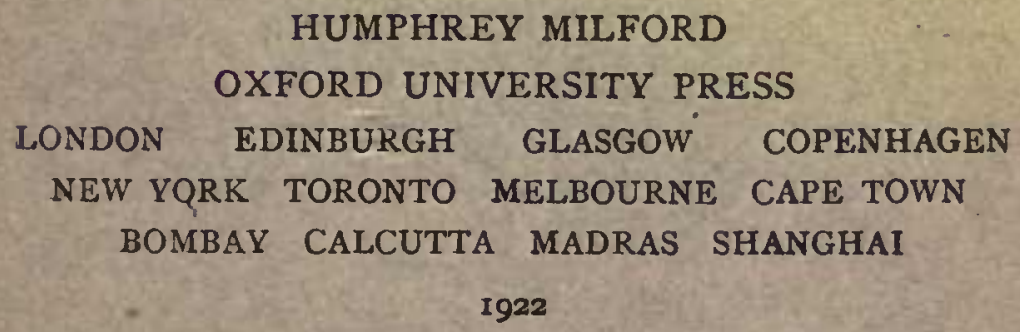






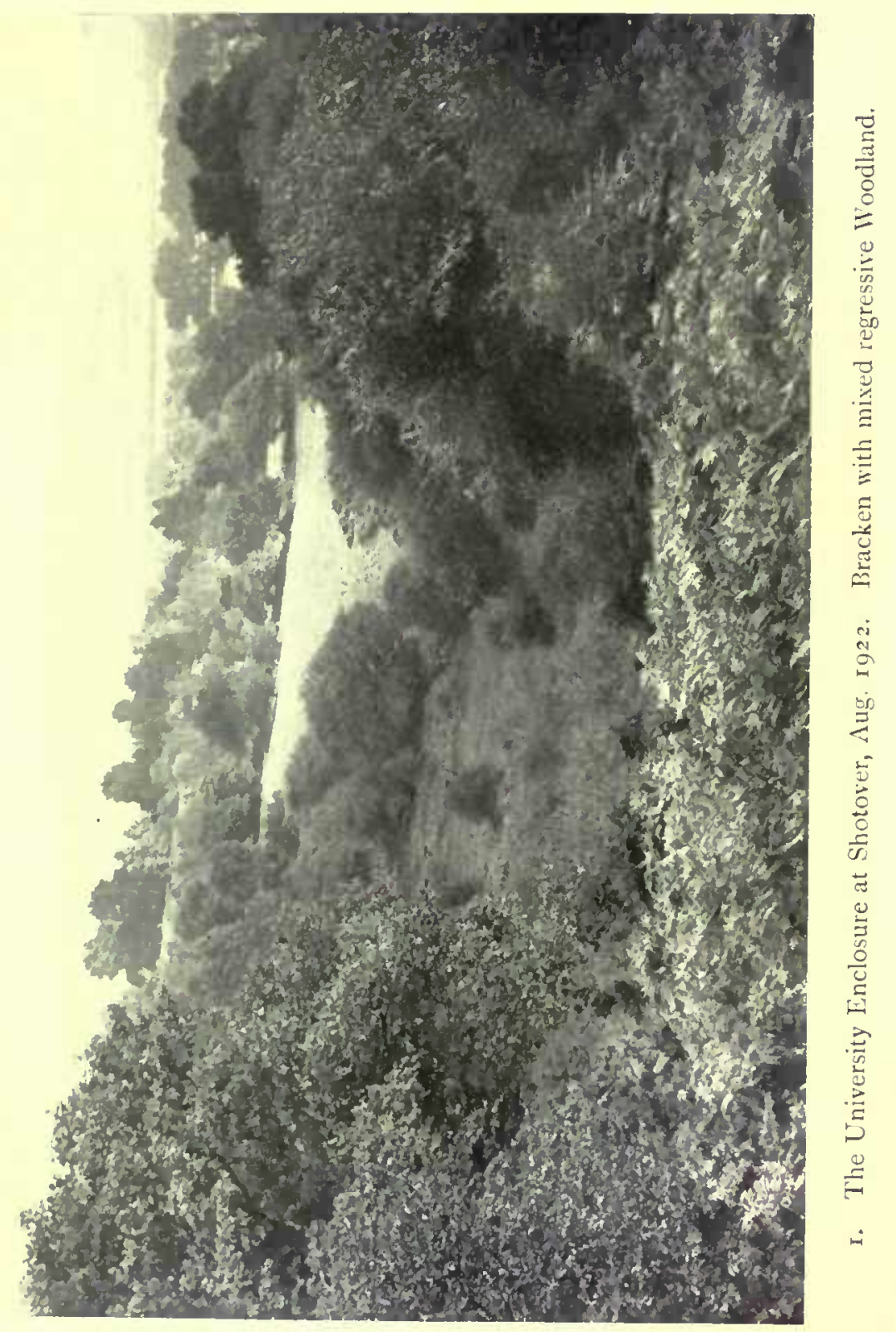




\title{
INTRODUCTION TO THE PLANT-LIFE OF THE OXFORD DISTRICT
}

\author{
I. GENERAL REVIEW
}

By

A. H. CHURCH, M.A.

$$
\frac{342642}{28.10 .37 .}
$$

HUMPHREY MILFORD OXFORD UNIVERSITY PRESS

LONDON EDINBURGH GLASGOW COPENHAGEN NEW YORK TORONTO MELBOURNE CAPE TOWN BOMBAY CALCUTTA MADRAS SHANGHAI 


\section{CONTENTS}

PAGE

I. INTRODUCTION $. \quad . \quad . \quad \cdot \quad \cdot \quad \cdot \quad \cdot \quad \cdot 3$

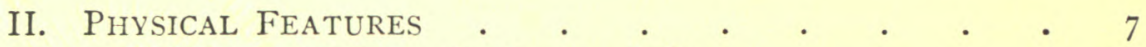

Climate, Geology, Surface-modelling . . . . $\quad$ Io

The Modern River-System . . . . . . 24

III. Primary WOODLAND AND its DERIVAtives • $\quad{ }_{2} 8$

IV. Subordinate and Herbaceous Flora . • • • 33

V. The Hand of Man . . . . . . . . . 46

Vi. Artificial Plant-formations . . . . . $\quad . \quad 53$

Woodland and Copse $\quad . \quad$. $\quad . \quad$ • $\quad . \quad 53$

Hedgerows and Hedgebanks $\quad . \quad$ • $\quad . \quad$ • $\quad . \quad 59$

Regressive Woodland . . . . . . . $\quad .63$

Grassland and the Evolution of Pasture . . . $\quad .65$

Roadsides . $\quad . \quad$. $\quad . \quad . \quad . \quad 73$

Crops and Weeds of Arable Land . . . . . . 77

Small Holdings and Allotments . . . . . $\quad .85$

The Regression of Cultivated Land . $\quad$ • $\quad$ • $\quad$. $9 \mathrm{I}$

VII. Aliens And Adventives • • • • • • • 93 


\section{INTRODUCTION TO THE PLANT-LIFE OF THE OXFORD DISTRICT}

ONCE free from streets and houses, considered as mere evidence of the gregarious habits of a modern population with the quite natural obsession that the world was specially designed for the welfare of the human race, it is only necessary to take an unbiased view of the condition of the surrounding country, to be inevitably inclined to the conclusion that, even in this part of the world, where half the year is spent in a struggle with the cold and storms of winter, Plant-life is enormously preponderant, and the vegetation of the countryside is the primary phase of life to be considered in dealing with all biological problems of the locality.

Trees or grass clothe the visible surface of the land, in close canopy or as thick undergrowth; animal life, beyond a few birds and the animals maintained by $\operatorname{man}_{,}{ }^{1}$ is conspicuously inconspicuous. Towns appear but as ant-heaps spaced far apart in the general green mantle of vegetation; and however much man may interfere with and attempt to dominate or even to replace the indigenous flora, his attempts are of doubtful permanence.

In point of time modern towns have a history of little over one thousand years $;^{2}$ that of the flora, even of this country, may be measured possibly in hundreds of thousands; and a modern city, with its fortuitous collection of human beings, may as readily dissolve again, and their rejectamenta be lost and buried under returning vegetation. An enthusiastic entomologist has claimed that the present age is pre-eminently that of insects; a medical writer might with equal acumen describe it as the age of bacteria. Omitting any considerations as to the relative importance of extreme lines of biological development, there can be no question that in all ages, as the base of the pyramid of life on this world, the autotroplic plant is the dominant factor for all time. That is to say, the living plant, on which we are still mainly dependent for our supplies of food and energy, is dominant in aggregate mass and volume of living material, as also in vitality and staying power, however much we may try to ignore the fact, and endeavour to extirpate the last persistent weed.

The flora of the British Islands, as a whole, is but the much deteriorated version of a European flora of the North Temperate zone; the latter again consisting mainly of successive migrants or survivals from a more subtropical environment, as vestiges of families, often represented by single genera, or by the last enduring species pushed farthest north. Of the British types of vegetation, that of the central plain of England is, again, the most inferior, in variety of forms, as of biological constituents. The local Oxford flora can show no heath-moors, alpine slopes, sand-dunes, shingle beaches or estuarine swamps, which have so attracted ecologists in other directions $;^{3}$ it remains characteristically commonplace, sylvestral, agrestal, paludal, with no special developments in any direction, and with

1 For stalistics cf. Orr (1916), Agriculture in Oxfordshire. Approximately I sheep for $2 \frac{1}{2}$ acres, a cow or bullock for 7 acres, a pig to 20 acres, and a horse used in field-work to 40 acres.

With intensive cultivation a cow may be kept on an acre of pasture, representing the photosynthetic output of some 5 million plants.

2 The Oxford Millenary celebrated 1912.

3 Carey and Oliver (1908), Tidal Lands.

Tansley (IgII), Types of British Vegetation. 
little to attract the visitor from other more favoured districts. Yet it is this very commonplace character which constitutes its greatest asset. With attention no longer distracted by special factors or extreme conditions of soil and water-supply, one may settle down to the examination of just what constitutes the ordinary flora of the river-valleys of the central plain of England, its limitations and its expression in common types which represent the response to a fairly average condition of environmental factors. Recognizing, again, the important fact that however commonplace such a flora may be in the present locality and conditions, it is not so very widely spread. The floras of other more emphasized biological districts are equally commonplace to the natives of those regions, and the plants of an English countryside may have a special scientific interest alike for the inhabitants of Greenland's icy mountains or those of India's coral strand, as conversely the English botanist is expected to be familiar with the ecology of these distant lands. ${ }^{1}$ To a floating population of students, the analysis of the local flora may serve as a guide to the methods of attacking the general problems of plant-life quite as well as that of any other. Though it may be characterized as 'homely' in its general features, ${ }^{2}$ it is nevertheless essentially British and English in its more fundamental factors. In spite of modern tendencies for admiring any country but one's own, it must be remembered that for all those who in this country are still privileged to trace an Anglo-Saxon origin, plant-life of this description has been intimately associated with the life of the essentially English race for a period of some $5^{\circ}$ generations ( $\mathrm{I}, 500$ years). To our mediaeval ancestors the ecological factors of the plant-life of such a countryside, with its woodland, pasture, arable land and streams, were the primary factors of their own lives also; as their continued existence and material comforts depended solely on the special plant-products of the land, whether in the form of timber, ${ }^{3}$ food-grains, fodder, vegetables, fruit, and even medicines, ${ }^{4}$ to an extent that is difficult to realize by a present town-bred population fed mainly from overseas; while 50 per cent. of the nation live in towns of 50,000 inhabitants or more, and even in the smaller towns comparatively few are brought into direct contact with the primary life of the district around them. While, again, in the past, the common plant-lore of the countryside has been naturally incorporated in older English literature, as typified by the Shakespearian drama, books are written for a modern urban generation to explain the 'plant-allusions' of Shakespeare, ${ }^{5}$ just as Bible-students require to be primed with references to an equally unfamiliar flora of Palestine and the ecological relations of the Syro-Arabian desert.

The present discussion is restricted to an account of the region more immediately surrounding Oxford, within reasonable distance for investiga-

1 Troup (1921), Silviculture of Indian Trees.

Schimper (1903), Plant Geography, Eng. Trans., p. 688; Holttum (I922), Journal of Ecology, $x, x$, The Vegelation of West Greenland.

2 P. B. Shelley, Univ. Coll. I8ro, "The Country near Oxford has no pretensions to peculiar beanty, but it is quiet and pleasant and rural, and pnrely agricultural after the good old fashion.'

3 In early timcs the success of English armies was based on the equipment of archers with a remarkable type of self-bow determined by the special properties of the wood of Taxus; as in later times the navy depended on the quality of English-grown Quercus. Oak-limber also gave efficiency to building construction.

4 British Botany begins officially with the essentially medical works of Turner, 1551 .

s Grindon ( $18 \mathrm{~S}_{3}$ ), The Shakespeare Flora : Ellacombe (1878), The Plant-lore and Gardencraft of Shakespeare. The Shakespeare-country, as more particularly the district around Stratiordon-Avon in Warwickshire, is but 27 miles NW. of Oxford. The character of the flora is identical; the same masses of woodland, alluvial pastures, and slow-moving streams are characteristic features; and the Avon at Stratford is closely similar to the Isis above Oxford. It is also interesting to note that neither of these exponents of Shakespeare's hotany, on general principles, appears to bave been very familiar with the ecology of the Stratford countryside. 
tion at all times of the year, covering an area represented by a 3 -mile radius from Carfax, or to the tops of the low hills surrounding the Oxford basin. A little commonplace flora, fairly known, and above all lived with all the year round, may prove quite as useful educationally as scrappy attempts at covering a wider area, or concentrating on the solution of the more spectacular problems of a few aberrant types. The text is thus designed, not so much to cover the story of plant-life in general, or the British flora in particular, as to suggest a simple method for beginning on any Flora which may be encountered, using local plants as the material provided. The older and time-honoured method pursued by past generations, of the isolated amateur who bought a local or British 'Flora', and tramped the country in order to find all the species recorded, and so complete his 'Herbarium', is not only time-consuming but unscientific, leading to species-hunting and the theory of the lost sheep, by which the ninety-nine common plants are neglected in the transports of finding some obscure or critical type 'new to the district'. '

It is sufficiently obvious that the first problem will be to find out the conventional names of the plants concerned, in order to check their specific descriptions and biological peculiarities, as already chronicled in a copious literature $;^{2}$ but it is recognized that the first duty of any University or teaching institution is to provide oral instruction, and not to leave the beginner to waste his time and break his energies in preliminary exercises which may be readily covered in class. Nor is there any need at this stage of the world's history for the individual student to recapitulate either the work or the ideas of his predecessors. It may be therefore clearly stated that the necessity for oral instruction and facilities for obtaining it in the Botanical Dcpartment are assumed.

The scope of the work falls naturally under separate headings :-

I. A preliminary review of the factors of the environment, and the general relations of local plant-life to these factors, as emphasized more particularly in seasonal change.

II. An account of the individual plant-forms included within the flora and isolated as conventional species, constituting the more strictly Floristic part of the subject.

III. The more intimate relation of the associated plants to their conditions and each other, as determined by continued observation and experiment, constituting what has become known as their Ecology.

For this last purpose, in addition to the general record of the flora, a number of stations may be isolated, as generally typical-about I2 being considered sufficient for the purpose. These again are restricted to sample tracts of small area (as stretches of 100-500 yards, or a few acres), providing a partial flora of about 100 species, as a set convenient to handle; capable of being checked within an afternoon of 2-3 hours, and of being followed throughout the year.

The point of immediate interest is to put down on paper the more obvious data; and with these at hand, it should be possible to pass on to more detailed examination. If the initial stage of record be omitted, the whole subject remains nebulous and vague; just as it is difficult for the ordinary person in winter to recall and visualize the summer conditions of hedge and woodland, or vice versa. Even to see what is obvious requires eyes, and the vision of the outdoor botanist must be stimulated by a

1 Watson (1849), compiling early ecological data for his Cybele Britannica, notes (vol. ii, p. 113) that the common Gronndsel was not recorded for 20 counties, and the common Daisy similarly passed unnoticed in 17 counties of Great Britain (loc. cit., p. I 25 ).

2 Babington (I922), Manual of British Bolany, Ioth edit. 
laboratory training in the methods of modern science. The epoch of the collector and systematist, as also of the amateur naturalist, whose elementary knowledge of the structure and organization of the plants with which he was dealing has been so conspicuously inadequate, has done its work. It remains for the ecologist to carry on the tale, more particularly from the standpoint of the life-problems of the plants themselves.

Such a record of the obvious presents an initial difficulty in the effects of rapid seasonal change throughout the year, to which plant-life responds by presenting short vegetative and even shorter reproductive periods. Large numbers of species come on, flower, fruit, and disappear within a few months, and many are only available at their optimum floristic range for a week or two in the year. Hence the efforts of many seasons may be required to determine the biological relations of a single type, and such investigations make slow progress. But it will be the more evident that collective work is essential, and control by a departmental organization, independent of the individual workers, who may also come and go as the flowers of the field themselves, can alone be effective.

Again, in dealing with the plant-life of such a district, the botanist is obviously primarily concerned with the plant-forms indigenous to the soil, as developed under a rigorous and long-continued process of natural selection. But as human activity sceks to dominate the flora, and to convert it to its own uses, certain plants are encouraged as being more valuable for food or other economic purposes, others are introduced, and these are further developed at the expense of the original vegetation which thus appears relegated to an inferior position, to be classed as 'weeds'. In a district where human agency has thus interfered with every province of the original flora, the botanist has at first to work largely in terms of such relegated weed-flora; whether as the residual forms of the forest underwood, the wild flowers of hedges and pastures, or the admitted weeds of arable land, allotments, and garden-ground.

But that is no reason why the field-botanist should therefore confine his attention to the primary flora and its vestigial representatives with admixture of aliens as weeds of cultivation-his province is to deal with all the phenomena of plant-life. Cultivated plants, their various sub-races, their artificial selection, and their relation to the special biological environment of the district, are equally a subject for scientific analysis and experiment. Hence no account of the indigenous flora can be complete without the adequate recognition of these aliens of modern cultivation; and the latter become the more interesting as they may be of exotic or even sub-tropical origin, modified by the skill of man, and still maintained in a state of wholly artificial existence by the care of the forester, agriculturalist, and horticulturalist.

Similarly, the extension of the indigenous flora to the cultivated flora is further enlarged by paying attention to the lower types of vegetation, as survivors of older phyla now relegated to inferior stations, filling the gaps between higher forms, as Pteridophyta, Bryophyta, Algae, Fungi, and even Bacteria, many of which appear as "pests" of cultivation, in their efforts to secure some sort of station and continuity of existence in the strain of competition with the more advanced and successful forms of the vegetable kingdom of to-day.

The business of the botanist is naturally to attempt to arrive at a clear understanding of whatever plant-life may be around him. In a tropical forest, where this phase of living organization is still dominant, he may study vegetation in its most aggressive form. In a northern climate where plant-life is struggling against the conditions of the environment, the 
varying features of the conflict afford the most interesting ecological outlook. In a civilized country, where vegetation wages an unequal conflict with both the environment and the aggression of human interference, he must be content to deal with these combined effects, as, in their way, equally likely to result in changes and possibly striking new departures in the plantstory. The consideration of the admittedly deteriorated flora of the Oxford district may thus serve as an introduction to the study of a more natural area with dominant types of vegetation. There is no need either to attempt to glorify it as being particularly unique, or to deprecate it as valueless. The point is to present it in its exact relation, as a training-ground in fieldwork for members of the Oxford Schools of Forestry and Botany, who may be called on to deal with wider problems of plant-life in any part of the world.

\section{PHYSICAL FEATURES}

Before dealing with the general physical factors of the environment it is necessary to explain how it is that the Oxford district becomes available for present investigation, and the part played by man in the establishment of what is termed civilization from the original wild; Oxford being now a large urban centre, as well as a University, to which the local flora appears at first sight as a mere trivial appendage, of aesthetic rather than of essential biological significance.

Oxford, ${ }^{1}$ a town of some 60,000 inhabitants, which has given its name to the University and also to the county of Oxfordshire, is situated on the Upper Thames (Isis), in longitude $I^{\circ} 16^{\prime} \mathrm{W}$. of Greenwich, and latitude $5^{1^{\circ}} 49^{\prime} \mathrm{N}$. The name suggestively indicates that the University and City have grown up in the vicinity of a ford practicable for cattle over the Thames (at Folly Bridge), marking the course of an old route running North and South to mcet the river road to Abingdon, and this is commemorated in the City arms. The centre of the town is still indicated by a Four Cross (Carfax), as the former main road cut another track running approximately $\mathrm{E}$. and $\mathrm{W}$., crossing the Cherwell by a ford near the Botanic Gardens (Magdalen Bridge), and extending now to cross the Thame at Sworford (E.), and the Isis at Swinford (W.). The fords were ultimately replaced by bridges ${ }^{2}$ still essential to the roads, but their original usage implies the neccssity for inter-communication in a district intersected by several streams, for which the present town marked a convenient centre. The ford-names still persisting may commemorate the ancient Saxon practice of taking stock to market; that is to say, the roads were tracks for herding cattle locally, while communication with the outside world was long maintained by the river. The fords were important as representing shallow stretches of gravel bottom, with a gravel approach affording secure foothold, in a clay district. A market at the best ford naturally followed.

Place-names of adjacent villages indicate that the early settlements and routes belong to Saxon times. The older Roman road from Bicester and Alchester to Dorchester, still remaining in part, avoided the low-lying floodareas as much as possible, and once across Otmoor, passed $2 \frac{1}{2}$ miles to the

1 The word is first written Oksnaforda in the time of King Alfred, but may be merely a corruption of an older pre-Celtic place-name; cf. local names as Oxey Mead and the River Ock at Abingdon.

The first bridge over the Thames (Grandpont), at Folly Bridge, was built by Robert d'Oili, the first Norman military governor; that over the Cherwell at Magdalen Bridge being Pettypont. The Grandpont was probably a drawbridge, and may have been associated with a canseway. 
east, almost due $\mathrm{N}$. and S. along the higher ground, through Beckley and Stow Wood, ultimately to cross the Thames at Wallingford. There is no special evidence of earlier cultivation or settlement in the valley, though ancient British, as also Roman colonists, may have occupied higher ground on the adjacent hills. ${ }^{1}$ Early West Saxons of the sixth century cleared the lower levels as meadow and pasture-land, replacing the original scrub of the valley swamp-area; and the names of villages and hamlets following the margin of the old flood-line sufficiently indicate the mode of settling in this river-valley; cf. Marston, Cassington, Yarnton, Kidlington, Kennington, Appleton, Eaton, and Botley, Bagley, Cowley, Iffley, Radley, Medley, suggesting meadow clearings," meadows, and minor islands in winter. Older river-names (Thame, Thames, Windrush, Ray, Evenlode) go back to prehistoric times, and the more upland villages apparently indicate remains of British and Celtic settlements on higher ground ( $300 \mathrm{ft}$. or more), Cumnor, Cuddesdon, Baldon, Foxcombe, and possibly Headingt(d)on, Garsingt(d)on. ${ }^{3}$

The Saxon town, as central for a wide meadow area, with unlimited pasturage for cattle and horses at all seasons of the year, became an important royal city of Mercia, at the limit of its junction with Wessex, commanding the approach from the West to the North in the angle of the river (seventh century). Taken by Wessex (752), and back again by Offa of Mercia (779), it again finally reverted to Wessex (912) under Edward the Elder. Burnt three times by the Danes (979-10ro), and occupied by them in the eleventh century, it had been again wrecked before the Norman Conqtiest, and half the houses were derelict at the time of the Domesday Book. The population at this time has been estimated at $r, 700$, and it is sufficiently obvious that it was self-supporting. The military significance and political importance of the town was probably due to its value for camping ground; a fact which lent it an increased significance as a convenient centre for meetings and conferences. ${ }^{4}$ The City and the beginnings of the University, said by University College to date to the time of King Alfred, grew up more definitely from the time of the Norman occupation, under the control of a Norman Castle commanding the river-approach (IO7I). In these early times much of the land had already passed into the control of the Church, as represented by Abingdon Abbey, which also collected river-tolls, and the original city was a walled area occupying gravel mounds emerging but a few feet above the winter floods, with Carfax as centre. The cultivated areas of the outlying townships passed under the Feudal System of Norman times, the Saxon small holders becoming villeins of the Norman manors. The city received a charter from Henry I about I I 30 , and the first University lectures (Theology) are recorded for $1 \mathrm{I} 33 .^{5}$

1 Remains of a Roman villa at Beckley, pottery on Hinksey Hill; pottery at Sandford, and a Roman horseshoe at $18 \mathrm{fl}$. deep in the gravel of New Hinksey (1922).

- Saxon place-names showed a general appreciation of ecological factors, owing to the fact that they were essentially a cattle-rearing people, dependent on the maintenance of borses, cattle, sheep and pigs, which also required to be fed. Woodland was wood, not forest; a ley indicates an artificial grazing ground as cleared land, as it is still nsed for artificial grassland (clover-ley). Open rough grazing in the field (feld, feldi) implied open grassy waste, which when dry became heathland, and when permanently wet and waterlogged, moor. These terms bave their equivalents in Low German; but for the upland pastures of rolling hill country, not a feature of the older German formations, they borrowed the British word dun, as down, as also coombe (cwm) for a deep valleyravine: cf. Otmoor, Northmoor, Littlemore, and Cumnor, Coombe Wood.

3 Cf. Alexander ( $19^{1} 3$ ), The Place-names of Oxfordshire, for the ohscurities of philology.

4 Plot (1 705), Natural History of Oxfordshire, p. 2 I.

The oldest building known is the church and convent associated with St. Frideswide, said to have been founded 727 , placed on the rising ground immediately above the flood-area north of the ford, now Christ Church (Cathedral, E. end). The castle-monnd is the remains of an ancient earthwork on the flood-margin, probably dating to the time of the Danes.

The oldest tree in the district is undoubtedly the Yew in Iffey Churchyard, possib!y as old as 
In early English times the main wooded mass of the country was dotted with hamlets, each with its own communal arable and grazing land, which in Norman times were affiliated as manors to large military landowners; Robert d'Oili, the first governor, collected some fifty manors by marriage with a Saxon lady. In the fourteenth century, following depopulation and the decay of the feudal system, land tended to go out of cultivation, cattle-rearing and the small holder again becoming dominant factors. In the sixteenth century the country was still predominantly wooded (Camden, $1586)$; on the west there was continuous forest over the Boar's Hill district from Wytham to Abingdon. Another great belt on the E. took in Shotover and ranged NW. to Stanton St. John. Open waste and heath-land extended over Bullingdon to Magdalen Bridge. Cutting of the woods went on in the seventeenth century, in the time of the civil war ; and during the eighteenth century, as the country began to settle down after the wars, agriculture tended to improve, enclosure set in on a large scale, hedges were multiplied, and the general aspect of the countryside began to approximate its present appearance. Old main roads rose to the tops of the hills above the clay as soon as possible, passing over open country without hedges; the London road over Shotover Plain, and the road to the west through Ferry Hinksey, Botley, over Wytham Hill to Eynsham. Much of the inter-communication of villages was by mere cross-country tracks, suitable for pack-horses rather than wheeled traffic. Many field-tracks between farms became public footpaths; others have been ploughed up, and the connexion lost, as has much of the Roman road. Enclosures in the eighteenth and early nineteenth centuries have completely changed the older order of the country, as the advent of the railway has that of the urban area. ${ }^{2}$

The modern city has spread largely northward along the most considerable gravel patch between the Isis and the Cherwell, extending some two miles along the Banbury and Woodstock Roads, and again about a mile eastward along the gravel patch of the Iffley and Cowley Roads. The levels of the water-meadows have remained largely unaffected, and the greater part of this area is probably much as it was when first cleared; but the higher ground has been progressively deforested and put under agricultural control, until little is left of the original woodland covering the undulating land beyond the alluvial swamp-area. The city area is 4,676 acres, or about 7 sq. miles.

In mediaeval times the City walls followed the flood-level on the river side, as still seen in Merton Meadows, and the river-gates were on the rise just above the Thames ford (Aldgate), and near the Botanic Garden (East Gate) where the Cherwell widened over shallows. The land outside the gates was utilized as the town-tip for refuse, which might be more or less washed away by winter floods, as a simple and effective method of sanitation ; or remained to raise the level of the ground (as it is still employed in Port Meadow), to be subsequently built over. A portion of this area was allotted to the Jews for a burial-ground; and such made-ground marks the original

the Norman Church itself ( 1160 ). The tree is now some $25 \mathrm{ft}$. high, with canopy $55 \mathrm{ft}$. diam.; it was probably once pollarded to give pole-shoots: the trunk 6-8 ft. diam. is a mere shell, and the head of foliage is formed by a mass of epicormic shoots which are continually produced.

t Plot (1705), Natural History of Oxfordshire; Murray (1912), The Making of Oxford; Enc. Brit., I th edition, Oxford; Gunther (1912), The Oxford Country; Orr (1922), A short history of British Agriculture : For general Oxford literatare the volumes of Anthony Wood, Parker, Boase, etc.

2 As a picturesque 'City of spires', Oxford is said to have looked its best at the beginning of the nineteenth century; Godley (1908), Oxford in the Eighteenth Century. At present the remains of the older City are buried in a mass of buildings, in which red-hrick villas and rows of small inferior houses are dominant, seen over a foreground in which railway, gas-works and allotment-areas are the most conspicuous features. The population in 1789 was 8,300 ; in a handred years it increased to 50,000 . 
tract on which the Botanic Garden was planted ( $\left.16_{32}\right)$. This land had been taken over by St. John's Hospital, which was later reconstructed as Magdalen College $\left(145^{8}\right)$. The area was still liable to total submergence by exceptional floods, until the 'New Cut' was formed after the last record rise of 1882 (as marked on the present bridge), and the level of much of the garden has been raised above the flood-line; though the Cherwell still occasionally tops the garden wall when in full flood (5 ft. above summer level). The present Departmental buildings have arisen as accretions based on greenhouses of different epochs. ${ }^{1}$

The nature of the environment, to which the plant-life of the district is subjected, may be conveniently considered from the standpoint of :-

(I) Climatic Factors, including sunlight, temperature, rainfall, etc., as meteorological conditions, and

(2) Edaphic Factors of soil and substratum, as essentially geological in their primary relations, including the drainage system of the rainfall in the form of springs and river-systems.

\section{Climate.}

Meteorological records for the Oxford district are readily available in the detailed reports of the Radcliffe Observatory, ${ }^{2}$ taken over a period of some seventy years, and few localities have been so thoroughly scheduled. ${ }^{3}$ On the other hand, meteorological data are often singularly ineffective in dealing with biological pinenomena, owing to the particularly complex nature of the problcms, and the difficulty in making the most essential records. Thus mere rainfall data are of little usc in themselves, without some knowledge of the amount of water freely drained off, the humidity of the atmosphere, and the deposition of dew on surface-vegetation. Probably hours of rainfall would be more illuminative than a record of the actual amount. Similarly the working valuc of sunlight in terms of intensity of photosynthesis bears very little relation to the recorded 'hours of bright sunshine'. Where such complex intcraction of factors is concerncd, the phenomena of plant-life, as exemplified in delicate organisms to whom such factors are a matter of life and death on a very narrow margin, probably afford a more reliable guide than the efforts of the human observer in his attempts at the discussion and tabulation of a few of the factors separately.

I. Temperature. The mean maximum temperature of the air, obtained by averaging the means for the 12 months, is $56.39^{\circ} \mathrm{F}$. (for 70 years, I $85^{I-I}-9_{20}$ ), and the monthly averages may be expressed by a curve from $43.46^{\circ}$ (January) to $70.67^{\circ}$ (July).

The corresponding minimum air-temperature is $42.45^{\circ} \mathrm{F}$.; from $34.37^{\circ}$ (January) to $53.28^{\circ}$ (July). This indicates on the whole a temperate climate, but does not present the effect of either summer heat or winter frost.

The highest air-temperature attained may be $94^{\circ} 7^{\circ} \mathrm{F}$. (Aug. 9, I 9 I I); and $8 c-90^{\circ}$ is commonly experienced on hot days in July, Aug., Sept. ( $91 \cdot 6^{\circ}$, Sept. I, I906), rarely in May $\left(83^{\circ} \mathrm{I}^{\circ}\right.$, May 30,$1895 ; 85.5^{\circ}$, May 22, I92I, B. G. O.). The winter months (Jan., Feb., Dec.) rarely rise above $60^{\circ}\left(61^{\circ}\right.$, Feb. Io, 1 899). Sun-temperatures may exceed I $50^{\circ}$ (rarely); I $53.7^{\circ}$, Aug. 9 , I gII.

Frosts may occur commonly in any month but June, July, and August ; but exceptionally in June $\left(28.6^{\circ}\right.$, June 25 , I 9 I 8$)$; while white frosts may occur

1 Gunther (1912), Oxford Gardens, p. 155 .

2 Rambaut, Results of Meteorological Observations made at the Radcliffe Observatory, Oxford, in 5 -yearly volumes; lii, $1916-21$.

Records of the Thames are taken in great detail by the Thames Conservancy : local data for the Cherwell at Magdalen College Laboratory. Rainfall and temperatures at the Botanic Garden: cf. Daubeay Reports, J. J. Manley, Magdalen College. 
in late August outside the town area. Records in the sheltered grounds of the Radcliffe Observatory, however, are often $2^{\circ}$ or more above those of outlying districts. No frost has been recorded in July for 60 years, but a drop to $33.5^{\circ}$ occurred in July I9 8 .

The lowest temperatures recorded on the grass are $-2.7^{\circ} \mathrm{F}$. on Feb. 5 , I9I 7 , and $-0 . \mathrm{I}^{\circ}, \mathrm{Feb} .8, \mathrm{I} 895$ (the coldest winter of modern times). A drop to zero, as a cold blizzard on the afternoon of Feb. 4, I9I7, and on the cold Christmas Eve of $\mathrm{x} 860$, is very exceptional. Frosts of more than ten degrees $\left(22^{\circ} \mathrm{F}\right.$.) may be considered less usual, and long spells of frost are rare. The severe frost of 1895 , over a period of practically 6 weeks, established a modern record. Snow-fall is inconsiderable; wholly wanting in some winters (I 920); the more usual case being one slight fall before Christmas, and another some time after, with little permanence of the snow-mantle beyond a week.

The full range of temperature thus affords occasional examples of Arctic cold, as well as Tropical heat; but temperate conditions are still the average experience.

II. Light. More remarkable is the low value of the sunshine record. Less than one-third of total daylight is included as bright sunshine; the average 'cloud' ranging very uniformly from $75 \%$ of the time in the winter months (Dec., Jan.) to $63-67 \%$ of the summer months (July, Aug., Sept.), leaving the average hours of bright sunshine as only $\mathrm{x} \cdot 38$ in December to 6.42 in June. Yet maximum sunshine may extend to over 15 hours (I 5.9, June 28,1921 ) in fine weather in May, June, and July; while in the darker months, maximum hours of sunshine may be occasionally $6-7$. But in the latter case it must be noted that with a low sun these are but equivalent to the morning and evening hours of the summer, and numbers of hours are by no means a fair measure of the photosynthetic value of the light. The year I 92 I was conspicuous for the brilliant and long-continued hours of sunshine throughout the dry summer into August, September, and the first half of October. In the two last months the cloud average fell below $50 \%$.

III. Rainfall. Data for net amount of rain are most readily collected, though the methods adopted are still open to minor errors. Wet weather is on the whole remarkable for its generally even distribution; a rough working average of one day fine and two days wet, more or less, obtains throughout the year. If no rain falls for a fortnight it begins to be regarded as a drought. The yearly average (70 years, $185 \mathrm{I}-1920)$ is just 26 inches $\left(26.022\right.$ ), ranging from $18.05^{6}$ (in I902), and the exceptionally dry season of I921 (I 4.95 in.) ${ }^{1}$ to wet years with 37.712 inches (I903).

Such records are open to the objection that exceptionally heavy rain for a few days may run up the total without any appreciable effect on the climate as a whole. A maximum of $\mathrm{I}-2$ inches may fall in one day (2.0IO in., June 14, I903), or $\frac{1}{2}$ inch in one thunder-shower. April 25, 1908, is registered as I.839 in. falling as continuous snow. A heavy rainfall which may rapidly drain away does not necessarily imply a wet year, the distinguishing feature of which will be a small but fairly continuous supply, or a heavier fall than usual in the summer months, associated with much cloud (1873). The monthly average throughout the year runs very uniformly at 2 inches a month (mean for 65 years) ; less in spring months, but more in the summer $(2.528$ July and 2.889 October). In extreme cases 6 inches a month may be exceeded (Oct. I903, 6.431 in.; Sept. I 896, 6.009 in.), usually with accompaniment of floods. Half the rainfall comes with a SW. wind.

1 In the exceptional drought of 1921 , beyond one or two severe thunder-showers (Ang. 17 ), and one wet day in September, there was continuous fine and dry weather from the beginuing of February to mid-October. In the meteorological records this appears as rain on 16 days in May and 16 in August; it being clear that dew is included in many cases as rainfall (even to $00 \mathrm{r}$ in. on some days). 
Owing to the damp state of broad alluvial tracts, a high day-temperature may result in fogs in the lower levels, especially in autumn and early spring ; while a sub-saturated atmosphere is often predominant for long periods in these districts, though the atmosphere on higher better-drained ground may be dry and clear. The scanty ancient population in British and Roman times kept to the hills, probably for military reasons. The Saxons cleared and cultivated the lower levels, and were largely restricted to the damp valleys by the necessity for a permanent summer water-supply for their cattle. The original urban area, as also adjacent villages (Marston, Cowley, Wolvercote, Binsey, Botley, S. Hinksey), follow the distribution of gravel-patches with better drainage than that afforded by the clay areas. More modern villa-residences again follow the hills where possible, as at Headington (now the second most densely populated area in the county), Boar's Hill, and Cumnor Hill, the further extension of which remains still limited by deficiency of suitable water-supply, restricted to scanty underground streams or deep borings, and with no reserves in case of fire.

River Temperatures average from $46.5^{\circ} \mathrm{F}$. as the minimum (March $\mathrm{I}$ ), to $55.2^{\circ}$ as the maximum (Sept. I), with a conspicuous lag beyond the air temperatures. In exceptional winters $(189 \mathrm{r}, 95)$ all streams freeze, including the Thames. In exceptionally dry summers all ponds and streams dry up, except the rivers bringing water from beyond the district, ${ }^{2}$ and a few minor hill-springs.

Soil Temperatures. The temperature is constant throughout the year possibly at $66 \mathrm{ft}$., a depth too remote for the purposes of plant-life. Records of the Radcliffe Observatory by Platinum Resistance Thermometers (I 898I 9I0) have been plotted for varying depths, showing that at the surface the mean air-temperature is fairly followed, with maximum in July, though $\mathrm{I}^{\circ}$ colder in winter, and $3^{\circ}$ warmer in summer. Lower levels show an increasing lag at $I_{\frac{1}{2}} \mathrm{ft}$., $3^{\frac{1}{2}} \mathrm{ft}$., $6 \mathrm{ft}$., to a deptl of $10 \mathrm{ft}$., at which the curve for riverwater is very closely approximated (or $46 \cdot 5^{\circ} \mathrm{min} ., 56^{\circ} \mathrm{max}$.), and the local occurrence of water in the gravel prevented deeper records being taken. ${ }^{3}$

Meteorological records have been also kept for the Botanic Garden since $186 \mathrm{I}$. (J. J. Manley, Magdalen College Lab.) These records show a wide range of variation from the official data of the Radcliffe Observatory, only half a mile away, probably owing to the fact that the garden is at a low level on the alluvium near the river, and even more sheltered than the grounds of the Observatory on terrace-gravel. 4

Thus the rainfall minimum of 1921 was registered as $13.96 \mathrm{in}$.

The record cold of Feb. 4/5, I9I7, is seen to have been due to local blasts of blizzard intensity; the minimum temperature on the grass that night being $20^{\circ}$, and a foot above the grass $4^{\circ}$.

The record hottest day, July $10,192 \mathrm{I}$, gave $85^{\circ}$ in the shade, and $\mathrm{I} 28.5^{\circ}$ in the sun. In July $192 \mathrm{I}$, the sun-temperature (absorption of radiant energy measured as heat) did not exceed a maximum of $130.5{ }^{\circ}$ and the hottest day ever registered at the gardens (Aug. 9, I $91 \mathrm{I}$ ) was $91.3^{\circ}$ in the shade, and $132.5^{\circ}$ in the sun, as opposed to $94.7^{\circ}$ and $153.7^{\circ}$ respectively, at the Radcliffe.

1 A coach and four was driven on the ice from Folly Bridge to Iffley, and the river was free for skating 10 miles below the City: Port Meadow flooded and frozen admitting skating to Wolvercote.

${ }^{2}$ In the drought of 1921 the Cherwell ceased to flow, the bed being dry at Islip in September, and the water only held up locally by the lock at Iffley.

3 It is clear that this water was a running stream (Timms).

1 Gunther (1916), Daubeny Laboratory Register, p. 172. 


\section{Geology.}

Oxford Clay: The beginnings of plant-life in the Oxford district, so far as available, may be said to go back to the horizon of the Oxford Clay, ${ }^{1}$ which forms a deep pan under the city and immediate neighbourhood, 200-400 ft. thick in places, apparently impervious to water, and covering Lower Oolitic strata, the outcrop of which comes to the surface away to the west on the Witney side, with the nearest outliers on the north, as the Cornbrash of Islip and Kidlington. ${ }^{2}$

This clay represents fine silty material laid down as subaerial denudation of the continental fringe, in shallow and warm sea-water, probably in broad, more or less land-locked lagoons of estuarine nature, as indicated by the massive oyster-like Gryphaea dilatata, which may lie in banks or as thickly distributed dead shells. ${ }^{3}$ The conditions of a warm sea are also illustrated by the presence of Ammonites and other Cephalopods (Belemnites). The clay is remarkably uniform in texture in the upper levels more commonly exposed, and the blue colour is due to ferrous sulphides which oxidize on exposure to yellow-browns of ferric oxides. This probably indicates the wastage of an adjacent volcanic land-area, as iron is practically negligible in the water of open seaboard.

At the base of the clay the material becomes more shaly (Kellaway beds), of hard sandstone with calcareous débris, occasionally bituminous with traces of lignite and iron, as the indication that the clay-deposit followed a depression of previous forest-land, with algal fringes, sinking and gradually covered with coral-reefs in shallower areas. Similar traces of lignite have been found in the deep boring (Brewery, I898) at depths of 375,396 , and $406 \mathrm{ft}$. beneath the City in similar shales and limestones of estuarine beds of the Lower Oolite.

This first vegetation of the Jurassic (Mesozoic) may have been of any tree-forms of the present world, Gymnosperm or Angiosperm; since at the time of the Upper Cretaceous plant-life of the world was to all Botanical purposes as good as it is at the present day. Angiosperm forest timbertrees, ${ }^{4}$ flowers with syncarpous ovaries, ${ }^{5}$ occur in Cretaceous deposits; winged land-insects in the Jurassic, even a butterfly. The time required for their evolutionary progression to this level is still beyond computation; but is probably to be estimated in hundreds of millions of years.

Though this great bed of blue clay constitutes so bold a feature in the local succession of strata, it represents but one of many long-continued periods of depression and elevation, following on from the older Lower Oolitic sea-floor, as the land on the fringing margin (Continental shelf, 100 fathoms) of one of the main surface-folds of the earth, rising from the 3 mile deep of the Atlantic Ocean, which may be visualized as expressing oscillatory effects with the rhythmic progression of the tide-periods of the ebb and flow of the ocean. ${ }^{6}$ Taking the Upper Cretaceous as representing

1 Pocock (1908), The Geology of the Country aronnd Oxford. Memoirs of the Geological Survey, with accompanying Map in colonrs, $I$ in. scale, and section E. and W. through tbe City area.

2 Cf. Islip Railway-cutting.

${ }^{3}$ In great quantity in lffley Road cuttings, 1922, to 8 in. : smaller forms 3 in. in the Wolvercote brick-pit; in other cuttings often wholly wanting : remains of timber in clay nodules, corroded and infiltrated with silica and iron pyrites, occur generally in apper Oxford Clay of the Wolvercote pit.

Stopes (1912), Phil. Trans., Petrifications of the Earliest European Angiosperms (Lower Greensand). All snch timber from the Oxford Clay, so far examined, was definitely Coniferous, showing uniform tracheides and medullary rays.

5topes (1910), Annals of Botany, p. 679, Crelovarium.

- Such oscillatory effects may be roughly indicated by noting that the present land-level of the Oxford valley is bot $200 \mathrm{ft}$. above the sea, and a drop of a foot in a loousand years would take it to the bottom of a 30-40 fathom sea (comparable with much of the present North Sea area) in about 500,000 years. Such a sea at sub-Iropical temperature would be foll of life, both plant and animal. 
a time-period of some 150 millions of years ago, there is ample time for a quite indefinite succession of such horizons, as depression to varying depths, and subsequent elevation and denudation, may involve successional strata of calcareous coralline deposits, clays and shales, sandstones and limestones, as the expression of rhythmic oscillations of even million-year periodicity. Successional strata of clays and calcareous sands and limestones in alternating series are the characteristic feature of the district, and such successive strata do not lie conformably on one another; as these main earth-movements have been associated with minor local oscillations, the effect of volcanic disturbances, and the possibility of repeated exposure as a land-surface, subject to subaerial denudation which may cut through several older beds.

Such periods may have been repeated over and over again for indefinite hundreds of millions of years before. Rocks of Liassic age thin out below the district, implying that there was more land exposed at that time; and these in turn rest unconformably on the far older deposits of the Carboniferous, below which are indications of deposits of Silurian seas. Taking the Carboniferous as some 400 million years ago, and the Silurian as 600 , even these horizons are probably but a short way to the time of the first elevation of land with the sea-weed vegetation of the sea.

The entire history implies indefinitely continued oscillatory exchanges of an old continental seaboard, with occasional variants, as larger denudations introduce estuarine conditions at the outflow of great continental rivers.

Omitting the higher beds of sands (Greensand) and clay (Gault) which are left as mere relics on the tops of surrounding hills, the Oxford district is built on three main systems :-

(I) Oxford Clay, giving clay soils at lower levels.

(2) Calcareous Grit and Coral Rag (Corallian Series), on rising ground.

(3) Kimeridge Clay, giving clay soils at higher elevations, and also on low ground to the SE.

In further detail, the Oxford Clay, though normally following an indefinite sequence of marine deposits of Coralline limestone of the Lower Oolite (Jurassic), to the Lias touched at a depth of $430 \mathrm{ft}$. below the City, as :-

\section{(A) Inferior Oolite (Limestone), Chipping Norton.}

Great Oolite (White Limestone, 'oolite', and marl) with estuarine beds.

Forest Oolite (Clay and Limestone), Hanborough, Islip, Witney.

Cornbrash (Limestone), Witney Bridge.

is in turn covered locally by :-

(B) Lower Corallian of Calcareous Grit and Sands, Headington, Cowley, Littlemore. Upper Corallian of Coral Rag and Coralline Oolite, Headington Quarry, Cumnor Hill.

A deposit of a foot of silt in 1,000 years while moving would give $300 \mathrm{ft}$. of deposit in 300,000 ; and at the same rate of re-elevation $200 \mathrm{ft}$. to the sea-surface, a million years becomes a small unit in accounting for the depression, deposition, and elevation of such a geological horizon. On a globe 1 metre diameter the total range of soch oscillation would be represented by a distance of 10 $\mu$.

These speculations are warranted from the estimates given by chemists for the disintegration of radio-active minerals found in older rocks. Such data are accepted, in absence of any other means of calculation, because they suggest agreement with the enormous distances of time required 10 explain the slow evolution of plant-life, as itself the most delicate response to the changing conditions of geological time (Holmes, 1920, Discovery, p. 112 ).

It is hardly realized yet that the enormons times suggested by these chemical deductions supply the one factor needed to make the biological machine work throughout the ages, at a rate no greater than things are changing at the present time; and that it was for want of these remarkable data that previous generations of biologists have failed to grasp the full significance of 'natural selection' over spaces of time, which to our senses are inconceivable, and what the history of life on this world really implies. At the Brit. Assoc. Meeting, 1921, Lord Rayleigh snggested some 8,000 million years as the possible age of the earth, and geological 'time' begios to bear a reasonable relation to astronomical 'space'. 
Kimeridge Clay, Boar's Hill, Horspath, Bagley.

Portland Beds (Sands and Clay), Shotover, Garsington.

Purbeck Beds (Limestone and Sand).

Wealden, Shotover Sands with Clay and Ironstone, Garsington Hill.

Lower Greensand, Boar's Hill, Cumnor Hurst.

Gaull, Clay, Cumnor Hurst, traces only.

To a much more recent age belong:-

(C) Plateau Gravel, Boar's Hill, Bagley.

Valley Gravel, Oxford City.

Brick Earth and Alluvium.

as the expression of the débris of the 'Glacial Epoch', and the enormous denudation following it, in the cutting of the present river-beds with their gravel 'terraces' and present alluvial and winter-flood area.

In the restricted Oxford district, series (C) remain only as casual deposits, with little reference to the subjacent primary construction; though significant from the local standpoint of surface-soils. Series (B) are left residual on the surrounding hills, and are denuded to the clay over a greater portion of the plain-area. Series (A) are not exposed within local range, nearer than Islip, but may be found by boring; just as Palaeozoic rocks of the Coal Measures are indicated at a depth of possibly I,000 ft. (said to be $\mathrm{I}, 200 \mathrm{ft}$. at Burford); though no coal or plant-remains have been so far recorded.

Plant-remains of higher beds may occur in estuarine deposits, as the sites may have been connected with great continental river out-flow; but, also, have not been recorded. The outstanding feature of the whole story is the prevalence in all older times of a warm climate, warm seas with coralreefs, gigantic estuarine formations implying forest-land, with the ground rising or falling over long periods of elevation and depression, or wholly changed locally with the lateral deflection of the estuarine deposits, following presumably alterations in the formation of adjacent predominant landmasses.

The Corallian Series: Of the surface of the Oxford Clay beneath the later deposits little is known; the soft material shows little bedding, and it is not clear whether it was elevated and in part denuded before again sinking in the Coral Sea of the Middle Oolite. Probably it was thoroughly denuded, hummocked, pitted, and dried, as tundra-like formation, giving shrinkage cracks to be filled later with sand-débris, which may become utilized as channels for subterranean streams.

The next beds show mixtures of sands and stone, as Calcareous Grit of Lower Corallian, ranging 20-6o ft. thick, with characteristic Corals, large Ammonites, and Mollusca. These again express a sinking coast, with inshore deposits as sand-bank formations in clean water. In places the beds become shelly, and at Headington a layer of pebbles ( 8 in. thick), with rolled material and shells, indicates an ancient beach; so that land was exposed close at hand. In other parts there is no appreciable break in the seadeposits. The most characteristic exposure is the deep bed of sand in the railway-cutting near Littlemore Station, $8 \mathrm{ft}$. thick, with massive septaria concretions, excavated for nests by sand-martins, and utilized for foundrycastings by the railway company. Sandy soils, cultivated as arable land, are characteristic of higher ground at $300 \mathrm{ft}$. at Hill Top, Headington, and also at Cowley, Littlemore; but in these the lime is commonly deficient, having been leached out. The woodland area of Tubney is on soil of the same nature.

Later deposits of Coral Rag (Upper Corallian) do not rest conformably on the preceding, nor necessarily conformably among themselves; the boundary between the two series may be ill-defined. Corals were particu- 
larly fine at this period, expressing massive reef-formation (cf. Honey-comb Coral Isastraea of Cumnor and Headington). Limestones may be so hard as to be utilized for building-stone in numerous local quarries (Headington Quarry), as the inferior building-material of the district. Such beds extend to a thickness of $12-40 \mathrm{ft}$., and are characteristic for Headington. Limestone rocks, cut down to Calcareous Grit sands, are still worked at Headington, and Coral Rag land, with abundance of broken corals, is seen in the large arable ficlds of Cumnor, N. Hinksey, Wytham Hill, Headington, EIsficld, Beckleyand Kennington, as also on the western slopes of Boar's Hill.

The upper limit of the Coral Rag gives, again, sands of more inshore deposits, and the upper surface of the stone may be water-worn, indicating exposure as land before it sank again to repeat a clay deposit of the Kimeridge horizon. Estuarine conditions were probably never far away; clays with nodules appear in the Upper Corallian of Littlemore, and the Ampthill clay which comes to the surface 7-8 miles to the east, at Waterperry and Worminghall, belongs to the same period. The most characteristic exposure is that of the railway-cutting at Littlemore, showing successive strata from clay with nodules above to a basal layer of hard rock covering the sandy mass of Calcareous Grit. ${ }^{1}$

The following Kimeridge Clay expresses again the silty estuarine deposit of a denuded area of volcanic activity; iron and sulphur in quantity being mixed with the lime débris of the sea. The dark clay is coloured with ferrous sulphide and carbonaceous matter which may indicate vegetable débris and algae drifted with the slow current. As in the case of the Oxford Clay, the deposit is that of a shallow sea full of life, including great saurians (Pleisosaurus, Ichthyosaurus) and common shells (Cardium, Pecten, Pinna) of recent seas, as well as large Ammonites (Chawley cutting) and oyster shells (Ostraea deltoidea, Headington), but no longer Gryphaeas. At Chawley Brickworks strata indicate masses of mud with débris of empty light Ammonite shells, as if floated to the limit of the tide-mark, suggesting estuarine beach-levels. At Shotover this clay is estimated at $100 \mathrm{ft}$. thick, with again traces of lignite. The most characteristic exposure is that of the cutting at Chawley, which is encroaching on Cumnor Hurst. This clay forms the greater part of the soil of Bagley Wood, as well as broad areas under Shotover, and to the south of Garsington Hill.

Above the Kimeridge Clay the conditions again conspicuously change to sandbank formation with clean water, giving 'Greensand' with glauconite (but now red with iron), and white coral limestone. The lower beds, about $60 \mathrm{ft}$. thick, are again separated from the upper 40-50 ft. by narrow clay bands. At Shotover the whole may be $100 \mathrm{ft}$. thick. These imply a long period of clean sea-water and coral-reef; though some may have been since metamorphosed by permeation of silica and iron.

Together with these, other traces of Cretaceous deposits also occur as Portland Beds, capping the morc hilly districts to the SE. (Baldon, Milton); and though these may be insignificant in floristic value, they remain the only guide to the progression of the formations and the condition of the land throughout the rest of the Cretaceous epoch well into the Tertiary. Traces of Purbeck beds, following on after the Portland beds at Shotover, are seen at Wheatley and Garsington; the special interest of which centres in the fact that they are more distinctly estuarine, grading into definitely freshwater deposits with fresh-water shells (Planorbis). In these Garsington deposits fragments of Coniferous wood occur, indicating the débris of forestland; while traces of an actual land-surface soil of this period have been noted Io miles away to the NE. at Brill.

1 Pocock (1908), loc. cit., p. 35, for detailed description. 


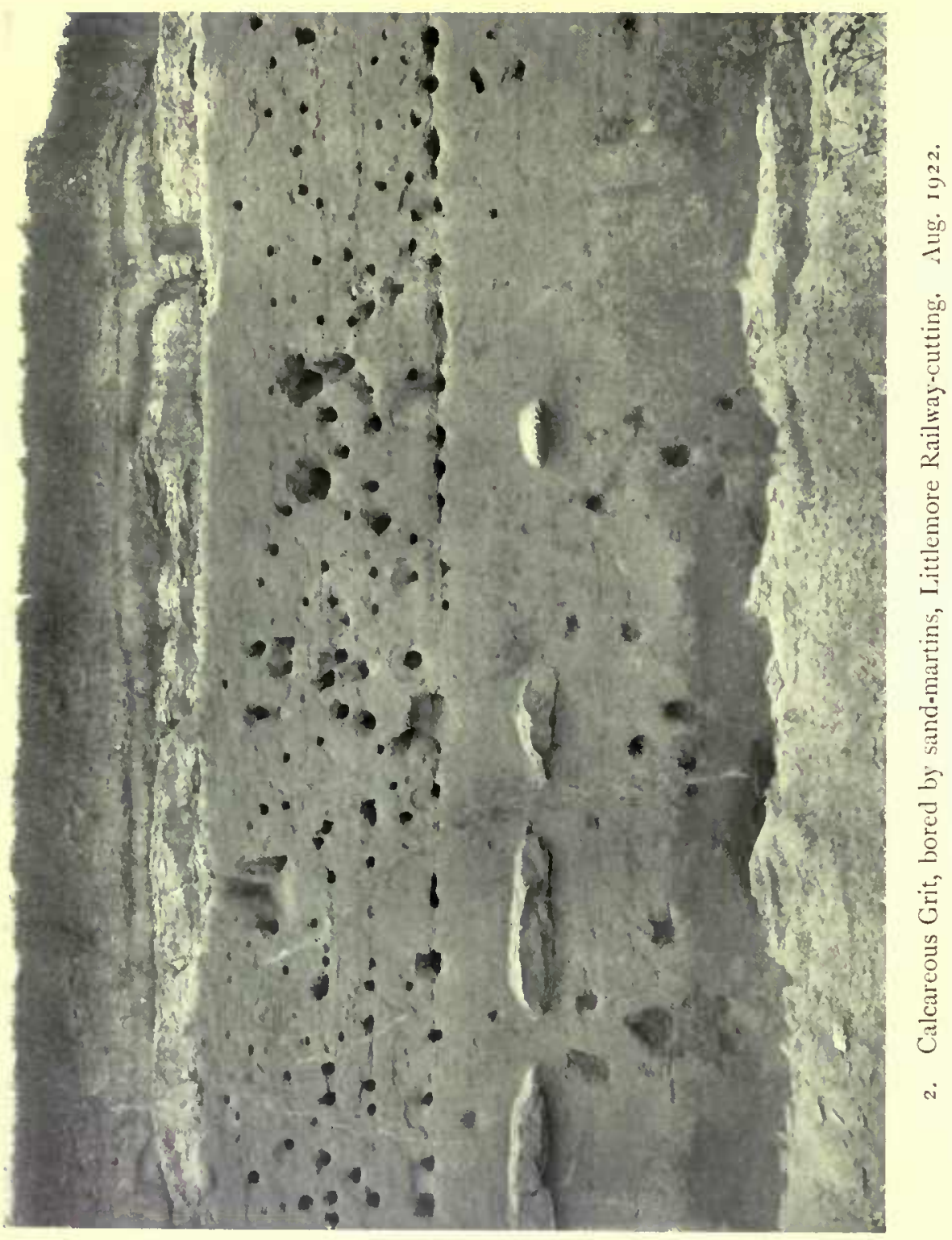




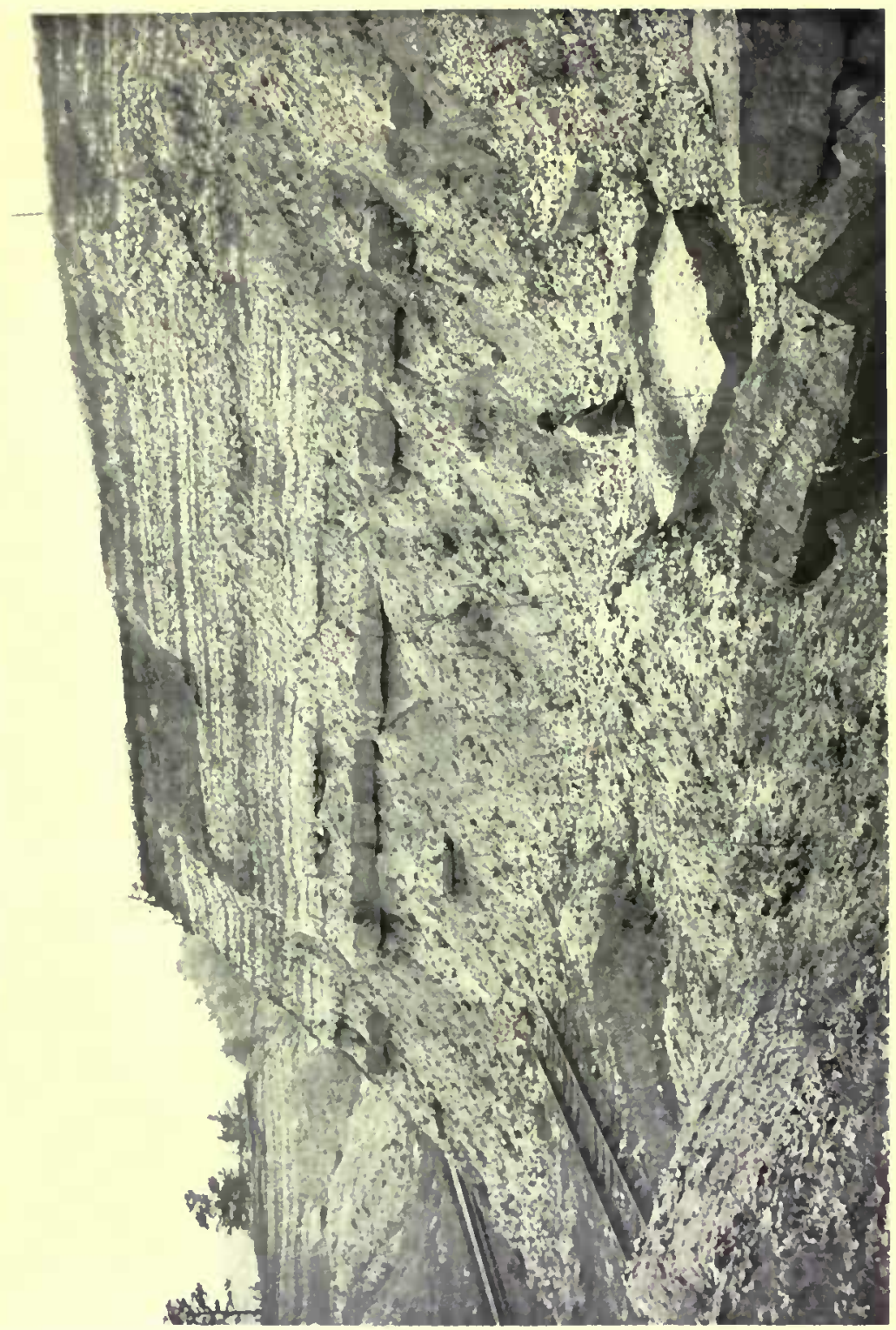

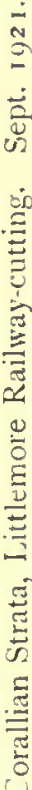

is 
Isolated patches of sands on Shotover, and at Brill, indicate apparently river-deposits of fresh water of the Wealden horizon; the sands being mixed with clays, and showing patchy deposits of river-sediments. Sandy deposits of similar character, also mixed with clays, are also left in isolated pockets on higher ground, more particularly on Boar's Hill and Cumnor Hurst, where they yield no fossils and rest directly on Kimeridge Clay. These appear to be of marine origin, and the intervening Portland beds must have been denuded before their deposition as Lower Greensand.

Small traces of a still higher clay at Boar's Hill, Toot Baldon, and Cumnor have been identified with Gault, which is predominant away to the SE., as the third great succession of an estuarine clay.

No trace remains of the Upper Greensand which represents the next clear-water deposit, nearer than Chalgrove, ro miles to the SE.; nor does the Chalk come any nearer than 12 miles at Wantage and Wallingford, with an outlier as Wittenham Clumps; though it is probable that the whole district was once covered with a great depth of Chalk-formation of warm and shallow sea.

Since this time, it would appear that the land has been wholly out of the water, and subaerial denudation has wiped off these later deposits, leaving only ridges and patches of the Middlc Cretaceous beds as the caps of the low hills of the district. Even before the exposure of the vestiges of Gault and Greensand on the adjacent hills, possibly $800 \mathrm{ft}^{\mathrm{I}}$ of a general Gault clay bed, with superimposed Chalk hills, had been cut away by erosion over a period of possibly 100 million years. This marks a wide gap in the geological story; but the record, continued with warm seas, coralreef, estuarine beds and the mighty rivers of the older continental area, over Mesozoic times, implies a land-surface of continental connexion with a vegetation far surpassing that of present times for the same locality, of which no trace remains. Of the land-conditions extending into the Early Tertiary Period (Eocene, Miocene), again, nothing is known; only in the late Pleistocene is the tale picked up again with the changes effected at the last 'Glacial Epoch' which is responsible for the surface-modelling of the district, as the Jurassic period has afforded the main material.

\section{Surface.Modelling.}

Post.Glacial Erosion : Only in the latest deposits of the Pliocene period is there any definite indication of the Pre-glacial flora of Great Britain, as presented more particularly in the Cromer Forest-bed, ${ }^{2}$ as a formation of estuarine swamp and lakes, with a temperate climate, to all botanical intent, identical with that of the present age. Large mammals still remained, and the Oak was a dominant tree, ${ }^{3}$ just as at the present day. This fact, as also the way in which the Oak is replaced in a slightly colder climate by Pinus sylvestris, and in a slightly warmer one by the Beech, ${ }^{4}$ very exactly defines the general nature of the flora, as essentially 'English' in aspect. With such a climate, and continental land-connexion, there can be little doubt that man of low-grade types, at the limit of the northern dispersal of the human race, had followed the plants and animals on which he subsisted.

These pre-glacial plants of the latest Pliocene, found on the coasts of Norfolk and Suffolk, are still characteristic of the British flora, with only a few additions suggestive of a more continental range (Picea excelsa, Trapa natans). Recognized examples include:-Coniferous trees, as Juniperus, Taxus, Pinus, Picea ; Angiospermous forest-trees, Oak, Beech, Alnus, Betula,

1 Pocock (1908), loc. cit., p. 107.

2 Clement Reid (1899), Origin of the British Flora, p. 35.

2 C. Reid (1913), Submerged Forests (Post Glacial), p. I06.

4 Warming (1909), Ecology of Plants, Eng. Trans., p. 203. 
Carpinus, Corylus, Acer campestre, Crataegus, Pyrus Aria; minor woodland-forms, as Cornus sanguinea, Rubus fruticosus; familiar herbaceous types, as Ranunculus repens, Heracleum, Lapsana communis, Solanum Dulcamara; aquatics, as Caltha, Hippuris, Hydrocotyle, Bidens tripartita, Menyanthes trifoliata, Mentha aquatica, Lycopus, Sparganium, Potamogeton, Phragmites communis and Osmunda. ${ }^{1}$

The advancing waves of cold of the Pleistocene, commonly foreshortened to our perception as a 'Glacial Epoch', culminated in an icesheet over practically the entire country; and the British Isles, together with Northern and Central Europe, passed into a condition which has been compared with that of Greenland and Spitzbergen at the present day. $A$ vast ice-sheet covered the mountains of Scandinavia; the North Sea was frozen, and glaciation extended as far south as the Thames Valley, entirely blotting out the flora of the northern parts of Great Britain, except for the possibility of the survival of a few residual Arctic types on isolated hills, and attempts at a residual vegetation in the non-glaciated strip, south of the Thames, over a short summer-season, much in the manner of the flora of Spitzbergen at the present day. The subtropical vegetation of the Tertiary Epoch ivholly disappeared, and the mean temperature must have been near the freezing-point most of the year. Arctic Willows have been traced in Devonshire; while the extension of winter ice-sheets is shown by the erratic boulders floated as far as the Isle of Wight, and even across to France. As the Oxford district is just beyond the southern limit of known glaciation, it is evident that the whole of the modern fora must have been immigrant since the time of maximum cold, however mild and temperate may have been any long-continued 'Interglacial Periods '.2

The revival of the temperature similarly inplies long-continued oscillation phases, just as does the advance of a modern spring on a smaller scale, and the so-called Palacolithic epoch commences with the first traces of man and his stone-implements. The country was gradually re-afforested; the flora as we know it was introduced from the adjacent continent; large mammals as the Mammoth and Woolly Rhinoceros followed; and with them came primaeval hunters living on fish, wild fowl, and anything available. ${ }^{3}$

No trace is left in the Oxford district of such times; the older strata are worn down to the level of the Oxford Clay, and superjacent strata are only left in patches, constituting the hills around the City. Much of these may have been denuded before the deposition of the Upper Cretaceous. The present modelling of the country is largely Post-Glacial, and has been effected by water-erosion; though to a certain extent the direction of the

1 C. Reid (1899), loc. cit., for complete schedule, p. I 7 . The flora was at this time dominant; and man, if actually existing in this land at that time, bad no effect on the vegetation: "He was only one more carnivorous animal added to a fauna which already possessed several quite as dangerous, and apparently occurring in greater numbers', loc. cil., p. 38.

${ }^{2}$ C. Reid (1899), loc. cit., p. 171 , for schedole of Interglacial plants.

As vestiges of permanent glacial ice still remain at $3,600 \mathrm{ft}$. on the Cairngorm Mits., at a distance of 400 miles from the Thames Valley, it might be supposed that the extension of the icesheet this distance farther south was really only a minor climatic phenomenon in the history of N. Europe. Much of the difficulty of the Glacial Epoch appears exaggerated when seen foreshortened, and changes in proportions of sea and land with diversion of oceanic currents, as the Gulf Stream, might bring on a similar condition of things. Spitzbergen enjoyed a subtropical climate with fanna and fora to correspond in the Miocene.

Cf. Brooks (1921), Nature, Sept., p. 90.

3 The heroic primal hunter chasing the Mammoth with a fint axe is probably a myth. The first immigrants were undoubledly a squalid race, the outcasts of the old world, with little knowledge beyond that of fire, fint, and sticks. At any rate man ir N. Enrope was already indefinitely old, and his tropical origin forgollen, Confusing decadent races, since apparently 'simple', wilh the actual stages of up-grade evolution, is sufficiently familiar in Botany, and is common to other biological
sciences. 
main streams indicates an older drainage-system of pre-glacial denudation, leaving channels to which the water returned after the melting of the ice. ${ }^{1}$

In the excessive denudation of this epoch, the whole land-surface was mobile, and torrential streams have sivept out broad river-valleys, leaving gravel deposits on their sides to mark the strength of the current, and giving rise to a residual system of water-courses, which at the present time dominate the surrounding country and its recovered flora.

The primary river-beds are of Pre-glacial and Tertiary origin, following the direction of the dip of the strata to the SE., and mark furrows between ridges 6-7 miles apart, of which traces are left in the Wytham-Boar's Hill and Baldon series, and the Shotover-Garsington-Milton line bounding the lower valley of the Cherwell, and again NE. in the hills at Brill.

The Thames itself is of later origin, as cutting across the line of the Oxford Clay from its source to Yarnton, at right angles to the preceding lines of flow, and hence ultimately reaching these streams; the great loop of the Upper Thames (Isis), north of the district, being formed by the river cutting into the course of the older Evenlode at Eynsham, and then into the Cherwell valley at Kidlington, to spread out over a broad area, 2-3 miles in width, and leaving gravel deposits dropped in successive steps to mark its ancient course, as also the periodicity of its torrent-flow, with alternating periods of less active action and deposition of alluvial mud only, as characteristic of modern times. The older the stages and the broader the valleys, the more vestigial are the traces remaining, and the deeper hollows of the valleys are now spread over by alluvial mud in which run the present diminutive streams. ${ }^{2}$

Plateau Gravel. Special interest attaches to the highest deposit of gravel at elevations of $100-350 \mathrm{ft}$. above the present river-bed; since it does not consist of local material, and was not laid down by existing streams. It consists predominantly of siliceous quartzose pebbles derived from more Northern sources, and is hence distinguished as Plateau Gravel of the Northern Drift, left as water-worn or glacial detritus in pockets and patches on old valley slopes, without any bedding or terrace-distribution. Such constituents are large Bunter Pebbles of the New Red Conglomerate from the Midlands, traced to the valley of Moreton, white quartz, variously coloured quartzose, sandstone of the Millstone Grit, and residual flints from the Chalk. The stones are rounded or sub-angular: but do not present any glacial striae. Smaller pebbles of this drift may have been washed into lower gravel deposits, and mingled with them; but all are to be distinguished by being non-calcareons, as opposed to the river-drift from oolitic rocks of marine coral-formation.

Erratic pebbles (up to 8-Io in.) occur abundantly on Boar's Hill; but there is no such drift on the Shotover side of the valley. A bed of such pebbles resting on Gault at Cumnor Hurst is $12 \mathrm{ft}$. thick, and $8 \mathrm{ft}$. on Boar's Hill; these spots being $290-35^{\circ} \mathrm{ft}$. above the river. Patches in Bagley Wood have determined the direction of the higher Abingdon Road: the stones are imbedded in a reddish clay. The drift is regarded as glacial in origin; ${ }^{3}$ but it probably represents the débris of older mountain torrents of the primary river-valleys, collected and distributed by later ice-sheets of the glacial epoch. At any rate, it is clear that if the high valleys of this period, so far little cut, were filled with ice to this level, i. e. $500 \mathrm{ft}$. above the sea, the protruding tops of the highest hills, even if much higher than at present

1 Pocock (1908), loc. cit., p. 106.

2 Pocock (1908), loc. cit., p. 82. The depth of the alluvium in the centre of the valley is abont that of the river, the main stream running on a gravel bottom with mud at the sides.

Pocock, loc. cit., p. I02. 
(Shotover is only $560 \mathrm{ft}$.), could have carried but the scantiest traces of vegetation.

The River Gravels and Terraces: So long as the land was more or less swept by the ice-sheet, the distribution of gravel was effected by glacial drift; but as soon as the ice melted, the Greensand and Corallian formations were again exposed to denudation, with the other beds of sand and stone forming the caps of the higher ground. The river-torrents, loosening the entire hill-sides, and fed by melting ice, brought down immense quantities of gravel of characteristic small limestone pebbles, stained yellow-brown with ferric oxides, and with only a small admixture of the older drift, as a post-glacial deposit. The streams flowed apparently at much the same low gradient as at present, with recurrent annual floods, and they swept the mass of the material down the Thames Valley to the sea; but they left gravel deposits or banks at the flood-levels, especially at points where the main current was checked in flow by the influx of a lateral tributary.

Interrupted at least at three special horizons, such gravel deposits are distinguished as giving 4 recognizable 'Terraces', at successive levels on the river-valley margins, separated by periods of more gentle erosion. These latter evidently represent cycles of warmer and colder climates; the less-marked erosion being the result of a mild winter, with little accumulation of snow and ice, and characterized by the animals of a warmer climate, as at the present day; the gravel terraces themselves being the indication of renewed cold and an intensified flood-system at the melting of the snow in the Cotswolds, and presenting indications of sub-arctic animals.

The Highest Terrace ('Fourth ') ${ }^{1}$ is $70-100 \mathrm{ft}$. above the present level of the river, as well as $50 \mathrm{ft}$. above the next below. Between Kennington and Radley there is a deposit $80-90 \mathrm{ft}$. above the river with abundance of oolitic pebbles. A similar terrace at Long Hanborough is $90 \mathrm{ft}$. above the Evenlode.

The 'Third' Terrace, formed after a long period of gentle erosion had cut the valley down another $50 \mathrm{ft}$., is left only as traces at Wolvercote, at 40-50 ft. above the river, at a level $30 \mathrm{ft}$. higher than Carfax. Fossil remains from this Quaternary bed indicate a cold climate with a peat bed, ${ }^{2}$ some Alpine plants (Mosses) not known in the district, together with some of the present flora, as also bones of Mammoth, Horse, and Reindeer; together with fine flint implements; the last being the first traces of human activity in the neighbourhood, and showing that man returned with the larger animals.

The 'Second' Terrace, some $20-30 \mathrm{ft}$. above the level of the river, is largely constituted by the great gravel-bed on which the city was built, extending from Carfax along the Banbury Road for about 3 miles, as not so much a 'terrace' as a broad pebble-ridge, now residual between the present bed of the Isis and that of the Cherwell, and ranging in some parts to $30 \mathrm{ft}$. in depth, commonly $12-20 \mathrm{ft}$. Bones of Mammoth, Woolly Rhinoceros, Hippopotamus, Horse, Lion, Wolf, Pig, and Reindeer have been recorded. The gravel may be 9-12 ft. deep in the centre of the town, with more admixture of clay than in North Oxford; the base of this gravcl is about

1 The numbering of these Terraces, following Pocock, loc. cit., p. 90, might with great advantage bc reversed in sequence, the highest being so obviously the 'first' in order of time, bowever much it may be the 'fourth', and also the least definite, in going up from the river.

${ }^{2}$ A. M. Bell (1904), Q. J. Geolog. Soc., $60, \mathrm{pp} .120-13^{2}$. A cerlain amount of error attaches to such determinations where the material is not collected personally with due precautions. Recognition of actual species from mere fragments of seeds and fruits is often open to suspicion, though the genus may be correct. Wind-borne seeds from adjacent weed-vegetation are readily drifted into cuttings, as well as malerial brought on maddy boots. Mr. Bell's material was looked over at the Botanic Dept. as mere slides of fragmentary débris. One of the likeliest-looking collections of seeds was planted in the garden and came up Chenopodium album. 
half-way down St. Aldate's. Adjacent villages, as Marston, are on outlying patches, and the Iffley and Cowley Roads follow another; the gravel thinning out in pockets along the Iffley Road to Fairacres. ${ }^{1}$

The Lowest and Last Terrace ("First') rises only 5-10 ft. above the flood level of the alluvium, and is seen as small patches of gravel; the most characteristic being that of the St. Aldate's side of Folly Bridge, taking off as the second terrace gives out, and forming on the other side of the river the base of New Hinksey. ${ }^{2}$ Small banks give the foundations of Lower Wolvercote, Binsey, N. and S. Hinksey, and the terrace is conspicuously marked in N. Hinksey fields, part of Port Meadow, and along the river-bank from Radley to Abingdon. It is largely covered by the alluvium. An isolated pit at Donnington gives inferior gravel with sand $8 \mathrm{ft}$. deep, in which teeth of Woolly Rhinoceros and Mammoth occur, again with stray flint implements as the water-carried débris of the Thames Valley. These materials may be of any age; just as Plateau drift pebbles are found as the base of the higher Terraces, and bones of the Mammoth in the alluvium and gravel of Magdalen Grove.

The River-'terraces' are more readily visualized as sand-banks once submerged, but now left high and dry with the fall of the river in the eroded valley. Gravel detritus would be dropped wherever the velocity of the main current was checked, as beyond a bend, spreading over flats, or where a tributary stream ran into the main river at right angles.

The Isis, cutting NE. along the Oxford Clay across the older valleys of the Windrush and Evenlode, stopped all gravel coming down these tributaries, forming the broad bank of gravel on the left bank of the stream (Stanton Harcourt, Eynsham, Yarnton). The highest terrace is beyond the range of the district at Hanborough.

At the confluence of the Isis and Cherwell, the 'third' terrace of Brickearth, above Wolvercote and Peartree Hill, remains as the vestiges of a sandbank, south of which the converging streams threw up the gravel-ridge of the long city patch in the middle line of their course, and the line is continued between the two residual streams as the 'First' Terrace of New Hinksey. The fact that both the present streams of the Thames and Cherwell cut through these gravels, explains the significance of the older fords at Folly Bridge and Magdalen Bridge as the only spots with a gravel approach on both sides of the stream.

The Marston gravel-patch indicates a sand-bank thrown up at the confluence of the Cherwell and the Bayswater Brook, and it is composed of material from the valleys of Barton and Headington. The Donnington gravelbank is a smaller deposit at the confluence of the Bullingdon Brook and the Isis, and is built up of layers of gravel with thin strata of sand from the Calcareous Grit of the Bullingdon Valley. The best pit (Io ft. deep, I92 I) shows very distinct layering, and the gradient of some of the layers suggests that the main flood-stream drove back into the valley of the tributary.

At its widest, from Wytham Hill to Elsfield, the full stream was some 5 miles wide, as a flood-area narrowing to the Sandford end, where it was never more than a mile wide. The stream at the 'Second' Terrace horizon was two miles wide over the City area; little over a mile at the alluvium between the Castle and Botley, where it is now restricted to half a dozen minor streams.

Special interest attaches to the "Third' Terrace of Wolvercote, partially exposed at the Brick Works, as it is largely composed of 'Brick-earth', now utilized for a special class of brick ('sand-stocks'), as opposed to the ordinary poor bricks of Oxford Clay still made from the clay of the $40 \mathrm{ft}$. deep pit. This 'Terrace' is a sand-bank pure and simple, and it affords the clue to

1 Pocock, loc. cit., p. 87 .

2 A cutting in the main road, New Hinksey (I922), which is exactly level with the river towpath, showed this gravel $20 \mathrm{ft}$. deep over the Oxford Clay. 
the City-area, as it also presents the first indication of human occupation of the land. It may thus be regarded as the original precursor of Oxford City in Palaeolithic times; though the site is still beyond the building area of Summertown.

The base of the terrace is of gravel and larger material with drift pebbles, among which flint implements are found casually in pot-holes on the surface of the subjacent Oxford Clay. The 'Brick-earth' consists of 'a mild clay' with a large admixture of fine quartz-sand, with no lime in the upper layers, probably brought across from the denuded top of Wytham Hill, and closely similar to the 'Greensand' at present found on Cumnor Hurst. The brown ironcoloured sand lies some $20 \mathrm{ft}$. deep in places, thinning out over the surface of hummocked Oxford Clay. This sand-bank represents the first land exposed in the centre of the Oxford valley, and the long bank of very uniform ordinary gravel of the 'Second' Terrace subsequently grew southward in the middle line between $W_{y}$ tham and Elsfield. At the edge of the bank the pure brickearth is mixed with minor layers of clean sand, blue clay, and gravel, as the changing debris of the river-current. The upper surface is also deeply potholed, and a few implements of later date have been found in these depressions. The top of the brick-earth is now covered by some $2 \mathrm{ft}$. of soil débris with small pebbles, etc., expressing the drift and accumulation of forest-land on the gravel substratum over the top of the low hill ( $230 \mathrm{ft}$. only); though the surface is now cleared, and from arable and pasture land, is chiefly utilized as golf-course and cemetery.

The fint-implements found in considerable number, considering the small area at present excavated, are not necessarily water-borne for any considerable distance, since they could only have come from higher up the hills, and may have been dropped in silu. ${ }^{1}$ They may have been washed into pot-holes; but the point is where did they come from. From the fact that they are found at the base of the Third Terrace, and also at its surface, but not in the Brick-earth itself, it would appear sufficiently clear that man was living in the vicinity in the milder inter-terrace period before the 'Third' Terrace was laid down, and again in the mild period following it. In the latter time probably on the bank itself. In such case there can be little doubt that the top of the hill became the site of a palaeolithic 'village'. Flaked flints in quantity suggest long-continued occupation. It will be noted that the hillock commanded the entire valley, and in flood-time would have been a central camp of refuge for other animals as well as man. The soil is well-drained, and water could be always obtained by digging pits to the clay below. The presence of a thin lajer of peat with vegetable remains (Bell) suggests at one time a backwater accumulating flood-debris. With a valley-swamp, low sand and gravel banks, the flood running 5 miles wide, any human occupants must have lived in wattle-huts, gone about in wattle coracles, and probably lived on wild-fowl; there was certainly very little else to eat. ${ }^{2}$

The general plan of the river-system by this time was much as it is now ; fine alluvial deposits fill the river-bed, with a flood-level broadening out over flat expanses, about $3 \mathrm{ft}$. above summer level. Extreme floods, to recent times, practically fill the old basin, following the contour line very closely; though drainage and the improved locking of the river has somewhat

1 Bell 1904), Q. J. Geolog. Soc., p. 120, strongly emphasizes the local origin of the implements of quarried flint.

I If it is only possible for a family under present conditions of good husbandry to get a living throughout the year on 30 acres of land; with no cultivation at all, the area may be possibly as many square miles. Or the problem may be considered from the standpoint of trying to live over the cold and wet winter months in the older parts of Bagley Wood, with no tools but a few flint knives. From this may be inferred the clensity of the population, and the ages of such elementary occupation. Nor on the other hand would there have been much feed for Woolly Rhinoceros or Mammoth. Either these animals were with man summer visitors, or their bones have accumulated in flood-débris at drinking places over long ages. The fact that the entire river-valley has been cut out 50 feet deeper since the Third Terrace began, as well as the depression of the entire area, may imply as many thousands of years, with a flora to all intents identical with that of the present time. 
lowered the flood-limit. The river runs on a similar gravel bottom several feet deep over the Oxford Clay. In the flood-meadows the alluvium is 2-3 ft. deep (Osney) over the gravel, and the gravel 8-r $2 \mathrm{ft}$. deep over the clay. The average depth of the stream is 8 -Io ft., except where the gravel has been removed for ballast-purposes. Off the main channel, kept clear for navigation, and where the current is reduced by locks, mud accumulates over the gravel as a nidus for many aquatic plants; but the clearest stretches show plants rooted in the gravel. The minor tributary streams (Bullingdon Brook), blocked with vegetation as the water is reduced in volume, give peaty bottoms from decomposing aquatics (rather than from Sphagnum). As the gravel bed (ro-20 ft.) of the Thames at Tilbury is $70 \mathrm{ft}$. below sealevel, on Chalk, it is probable that the entire valley has subsided $50-100 \mathrm{ft}$. since the Terrace Period.

\section{Soils.}

The peculiar shapelessness of the political county of Oxfordshire sufficiently indicates the failure of the 'county' idea as applied to any general account of its flora, and this is the more intensified in the case of the Oxford district, half of which is across the river and labelled Berkshire; while it is only 7 miles across (NE.) to Buckinghamshire. Similarly the Oxford Valley is by no means typical for Oxfordshire, which is made up of bare higher ground of the Cotswolds to the NW., and of chalk ranges of the Chilterns to the SE., any more than it is for the predominant chalk ranges of Berkshire.

The county extends over a long series of outcrops of geological formation, as Chalk, Upper Greensand, Gault, Lower Greensand, Kimeridge Clay, Corallian Limestone and sands, Oxford Clay, Cornbrash, Great Oolite, Middle Lias, \&c., of which the Oxford Valley takes only the central members, as a general mixture of clays and calcareous soils, again so blended by surface-denudation, the washing of upper strata over the surface of lower, and the great mass of alluvial drift as graveis and clay silt, quite apart from the nature of the basal geological formation, that the latter becomes relatively secondary. ${ }^{2}$

As a rule the Allwwium is mainly under grass. Valley gravels give arable land, and ploughed patches of fields apparently on the alluvium (South Hinksey, Binsey) indicate terrace-gravel. The clays, being heavy to work and cold, are again mainly devoted to poor grassland; or as in Bagley Wood, to trees. The Corallian rocks are predominantly indicated by arable land, as also the Lower Greensand and Shotover Sands, with the Portland Beds and Calcarcous Grit. The Coral Rag of Littlemore and Sandford, Cowley, Headington and Beckley, gives the best cultivated land. The woodland flora, however, being more dependent on humus and watercontent, shows little variation in woods on clay or on Corallian formation.

Lime is conspicuously deficient in Plateau Gravels, and in the more sandy soils of hill-tops, from which it has leached out; especially in the case of the Lower Greensand of hills, Shotover Sand, Portland Beds, and much of the Calcareous Grit. The river gravels of the Terraces, again, are mainly limestone, lime from which leaches out over the Oxford Clay. The alluvium contains a large percentage of organic matter, the more so, in the peaty bottoms of minor streams (Bullingdon Brook, Headington Wick). ${ }^{3}$ A few

1 County Floras, arranged according to the Natnral System, in which also the political area was subdivided by physical features of river-areas, came in with the Flora of Middlesex, intended as a London handbook, by Trimen and Dyer (1839). This has proved a facile but disappointing method of dealing with partial floras.

2 Orr and Morison (1916), Agriculture in Oxfordshire, Soils, p. I7I. Parts of Bagley Wood give a soil with $3^{\circ}$ per cent. coarse quartz sand, free from lime, of the Boar's Hill Lower Greensand. type, mixed with fine clay and pebble drift over Kimeridge clay.

' Considerable deposits of peat appear to have been exhausted in search of cheap fuel, in the 
characteristic 'calcicolous' plants are found only in exposures of Coral Rag. ${ }^{1}$

\section{The Modern River-System.}

There is no reason to suppose that, during the known historical epoch of $I, 000$ years, there has been the slightest permanent change in the general physical conditions of the climate or general topography of the district $;^{2}$ and this fact has a suggestive bearing on the length of time included in geological periods involving factors still in operation. Minor alterations have been effected in the drainage system, and roads have made it more accessible, but in biological essentials the district remains the same. The alluvial plain is well irrigated by the branches of the Upper Thames (Isis) and its tributary the Cherwell, both bringing water from outside the restricted area considered; the latter joining the Isis below the town at the Barges, and by the artificial 'New Cut', formed after the heavy flood of 1882 , and replacing an older channel a little farther down stream. Though carrying down a considerable quantity of water in the course of the year, these rivers are little more than shallow broad ditches, which in exceptional summers might run wholly dry, ${ }^{3}$ as undoubtedly they often did in the past. The summer delivery of the Isis has been estimated at 73 million gallons per day, ${ }_{3}^{4}$ and the winter delivery as 320 millions. The City of Oxford requires about two million gallons a day as water-supply, this being taken from the Isis above the town near King's Weir.

The Isis, flowing north at Stanton Harcourt from its junction with the Windrush, brcaks away to the east at Eynsham, picking up the Evenlode, and rounds Wytham Hill to enter the old valley of the Cherwell, 2 miles from the present stream at Oxey Mead, and turning sharply SSE. at King's Weir it enters the Oxford valley from the NW. The main stream passes Godstow and Port Meadow to Medley Weir and Osney Lock, through the lower part of the city to Folly Bridge, Iffley, and Sandford. A loop of the stream, breaking off at Hagley Pool, runs fairly parallel through Wytham, Ferry Hinkscy, and Botley. Collaterals and cross-connexions supply millstreams at Botley, Osney, and City Mills, and all these ramifications unite below the town. With the junction of the Hinksey stream below Iffey, the river is finally collected in a narrower channcl before Sandford and Radley, when it again turns west to Abingdon. This great 10-mile sweep of the Thamcs, the broad areas of alluvial meadowland, and the meandering course of the Cherwell with its own alluvium (NE.), constitute the more obvious features of the river-system. The network of streams west of the city is indicated by the fact that the road from the Castle to Botley, over a stretch of alluvium a mile wide, formerly crossed $6-7$ water-courses. The original water-system has been increased by a canal to Birmingham (Oxford Canal I 769 , completed 1790), running from the Castle Wharf north past Wolvercote,

valley of the Bullingdion Brook (Cowley), and the Bayswater Brook and its connexions (Headington Wick, Elsfield). Plot (1;05), p. 65 , clearly describes the cntting and drying of Peats, in one case from a 4 ft. seam. Sibthorp (1794), Flora Oxoniensis, describes Sphagmum as still growing 'in Peat Bogs on Bullington Green'. Special interest also attaches to a seam of Lignite (4 in.) at Kidlington, described by Plot (p. 66, luc. cit.), as indicating how the plant-remains of the soil-snrface have been already hunted through and exploited. The organic content of such alluvial soils may be considerable, and requires to be examined for different areas and depths: e.g., samples dried at $100^{\circ} \mathrm{C}$. gave-Bullingdon Bog Valley, mole-casting, 21.52 per cent. Ifley Lock Field, molecasting, 21.12 per cent. (taken near the ditch, an old water-course). Cherwell alluvium, surface-soil of hay-field, $7 \cdot 7$ per cent. (IV. R. Day).

1 Carduus nutaus, Cirsium eriophorum, C. acaule, Ilelianthemum vulgare.

2 The frost of Dec. II4Z was probably no more severe than that of March 1895 , and the condition of the water-meadows, particularly above Wolvercote, is much the same as at the time of the Domesday Book.

3 In August 1893 the led of the river was dry at Folly Bridge, and the steamers ccased to run; in 1921 the Cherwell was dry in places, stagnant for miles, with green mantle of Lemna.

1 Prestwich (18;6), Water-sopply of Oxford, p. 39 . 
and connected with the river-system at Duke's Lock. The country to the east is drained by minor streams as Bayswater Brook, Northfield Brook, Bullingdon Brook, the channels of which are cut as deep trenches 6-12 ft. deep, and as many wide. These may carry a full stream in flood-time, on impervious clays ; but are dry or dwindle to the merest runnels in extreme dry summers (I921).

The Isis Lock-system. For purposes of navigation, more particularly by barge, the Thames is held up throughout its course to the sea at 47 locks and weirs, of which 6 fall within the Oxford district (King's Weir, Godstow Lock, Medley Weir, Osney, Iffley, and Sandford Locks). A collateral branch of the Isis, taking off just above King's Weir, and rounding Pixey Mead to Wolvercote Bridge, is uncontrolled, as is also the Hinksey stream taking off at Hagley Pool, and running past Wytham : the latter is connected with an extensive system of ditches in the alluvial area below the town, joining up again with the main river at the Railway Bridge below Iffley. Even after locking, the river, though liable to be blocked and banked up by weeds, also tended to run out in summer, and barges might lie up for $3-4$ weeks. ${ }^{1}$ The lock-system was initiated in the reign of James I, and the mechanism remains much the same to the present day. ${ }^{2}$ The first barge, following the completion of the lock at Iffley, reached Oxford in August, I6 35 .

The navigable stream is seldom more than Io ft. deep, except where gravel has been taken out, leaving deep pits (Old Stream, Cold Arbour, and Isis at 'The Gut'); a depth of $5 \mathrm{ft}$. in the channel is sufficient for navigation, a minimum of $3 \mathrm{ft}$. 9 in. being maintained above lffley. The object of the Lock-system is to maintain the water at each lock at a maximum level ('Head Water'), a datum-line marked empirically for each lock, as the highest level to which the water can be kept without unduly flooding the land above. The distances above sea-lcvel are :-

\begin{tabular}{|c|c|c|c|c|c|}
\hline King's W & & .. & . & (H.IV.) I $93.55 \mathrm{ft}$. & miles between \\
\hline Godstow & . & . & . & $19 \mathrm{I} .02$ & $1 \cdot 10$ \\
\hline Medley & - & . & . & $I 87 \cdot 3 \mathrm{I}$ & $I \cdot 4^{8}$ \\
\hline Osney & . & - & - & I 85.89 & $\cdot 99$ \\
\hline Iffley . & . & . & . & 179.72 & $2 \cdot 40$ \\
\hline Sandford & . & . & . & 176.92 & $1 \cdot 38$ \\
\hline
\end{tabular}

The total distance from King's Weir to Sandford is $7 \frac{1}{3}$ miles, the fall $14.10 \mathrm{ft}$., and the average gradient $2.25 \mathrm{ft}$. per mile. Tail-water at the lockgates also gives empirical data based on the requirements of navigation, and records of such data are taken by the Thames Conservancy three times a day; so that the Thames is one of the best observed rivers in the country.

The total rainfall of the Thames basin normally ranges between $2 \mathrm{I} \cdot 32$ inches ( 1887 ) and 40.87 ( 1903 ), the average of $3^{6}$ years (1883I 918 ) being 28.32 . The Oxford data (Magdalen Laboratory) give 25. I6, and the Radcliffe Observatory 26.02 . Of this fall, less than half finds its way into the river-system, or $40.3 \%$ in the winter months, and some $21.5 \%$ during the summer; the larger proportion being returned to the atmosphere by evaporation and transpiration; while there remains a certain leakage in the form of subterranean streams which also pass beyond the local area. Or, for 28.3 inches (average) of rain per annum, only $3 \mathrm{I} .8 \%$ (varying 19-44),

1 Plot (1705) p. 239 (the text being written, first edit., 1675); p. 29, 'Our Watermen here in these shallow Rivers, praying not so much for Rain to fill them when low, as that Weeds may aiso grow to help to keep the Waters when they have them, which will otherwise too soon glide away to their no small detriment.'

2 Plot, loc. cit., p. 238 , described in considerable detail. The original 'Lock', with rimers and keys worked by levers, is seen at Medley, with only a slight fall. What is commonly termed a 'lock', with a double set of gates turned by a beam, was originally a 'turnpike'. 
or the equivalent of 9 inches (varying $4-16$ ) is accounted for by the riversystem. This leaves an approximate average of less than 18 inches per annum to supply plant-life; the suggestion being that an annual rainfall of 18 inches would be sufficient for the vegetation of the district, if the river did not run off more at Sandford than at King's Weir. ${ }^{1}$

Springs and Brooks. Apart from the main river-system of the Thames and its backwaters, canals and tributaries (Cherwell, Ray, Evenlode, Windrush, Thame), local conditions of water-supply including small streams and swamp-areas are more conspicuously dependent on actual rainfall and the relation of this to percolation through the soil, and the capacity of the latter for penetration and retention. The geological formation is peculiarly favourable for the throwing out of springs at all levels. As previously indicated, the basal formation of the Oxford Valley is a deep bed of Oxford Clay, which is apparently wholly impervious throughout the greater proportion of its depth. In this clay the present river-system has been eroded over the greater part of the district, the valley being covered with a sheet of alluvium to the limit of older winter-floods, while patches of gravel of older river-terraces are left as irregular deposits and the débris of torrential water-courses. These latter are freely permeablc as collecting areas, and water may be thrown out at any outcrop of the clay, at levels corresponding to the gravel deposit on an old clay bottom, at $200 \mathrm{ft}$. or more elevation. Over the clay, patches of residual beds of Corallian strata of limestones and sands, again more freely pervious, cover wide areas (as at Headington, Cowley, Littlemore, Tubney) with Coral Rag on hill-slopes and broad undulating areas (Hinksey, Headington, Cumnor, Stow Wood). At the exposed junction of these strata with Oxford Clay on the slopes of the hills (Cumnor, Headington, Wytham, Elsfield) springs are thrown out in large numbers, giving streams cutting decply through to the clay-bottom (Hinksey, Headington Wick, Bullingdon Bog), all tending to feed the main river-systcm, and also forming characteristic swampy patches on the clay sides of the slopes by producing Funcus, Phragmites, and Equisetum associations, at clcvations of $300 \mathrm{ft}$. or so nearer the city, as a second series of springs.

Over these more pervious rocks, broad tracts of Kimeridge Clay constitute another more or less impervious layer, more particularly on the Western side of the district, as in areas of Bagley Wood, Boar's Hill, Sunningwell. Locally, again, on the surrounding hills the Kimeridge Clay is capped by highly pervious patches of Greensand (Cumnor Hurst, Boar's Hill), Portland Beds, and Shotover Sands (Shotover, Garsington, Baldon), so that water percolating through these beds is largely thrown out in surface-springs at the junction with the Kimeridge Clay, at a higher level of about $400 \mathrm{ft}$., 2 giving an upper zone of springs, and again formation of Hill-swamps of Equisetum, Plragmites, and Typha, with Juncetum at this higher elevation. Patches of Plateau Gravel over Kimeridge Clay (Bagley), or over Gault Clay (Baldon), also assist in giving rise to similar high-levcl springs, and affording the water-supply of the population of these areas. Swampy ground with Mosses and Juncetum may obtain at any elevation, giving Funcus where most exposed, Equisetum Telmateia, in vast abundance in hollows or on Hill-slopes (N. Hinksey), Typha in standing pools (Chawley), with dense thorn-scrub in neglected tracts (Chawley Hurst, Headington Quarry).

All such streams cut deep hollows in the steep hill-sides, as indicated

1 In I92I, with extreme drought and rainfall 13.14 in. only, the Thames Valley used all the water falling on it. The Weir-steps were dry at Teddirgton in $\mathrm{Ang}$. and Sept., and a man crossed the river at the Weir pool (in waders). Vegetation obviously drew on deeper reserves in the ground, and was very insufficiently supplied by rain and stream.

2 Horspath, Chilswell. 
by the grooves in the contour-lines of the map, but are now running brooks of no great size, apt to dry up in hot summers, or left as mere runnels and ditches along the sides of fields, uniting to form such streams as the Bullingdon Brook, Bayswater Brook (Cherwell), Hinksey streams, Northfield Brook (Isis). Baldon Brook, Holton Brook (Thame), which may also run in considerable volume in times of winter flood, but in summer months are almost negligible.

Flood: One of the most spectacular features of the Oxford Valley is its tendency to flood at any time in the winter months. Both the Thames and the Cherwell bring water from beyond the district; the winter delivery of the Thames is several times that of the summer months, thus filling the channel. When wastage of evaporation and transpiration of vegetation is checked, and the average monthly rainfall increased, water tends to accumulate, the more as the predominant clays are impervious; and on the alluvial flats the water runs off with difficulty. The control of the main stream of the Isis for purposes of navigation pinches the stream at locks and weirs, older water-courses may become filled up, and water may be intentionally held up in the upper reaches of the river in order to reduce the excessive flooding of tracts farther down stream. Though filling the alluvial basin in older times, improved control of the stream by deepening the channel and the regulation of weirs has considerably lessened both the extent and the duration of the flood, and further diminution is probable; but when Port Meadow, Osney Fields, Iffley Fields, and the Cherwell Meadows are under water, the aspect of the country returns to its primary winter condition, with hamlets spaced along the flood-margin and the town on its gravel bank, appearing from the surrounding hills as more or less isolated in a broad lake.

Above the locks flooding follows as soon as the stream runs much over Head Water, and below the locks where the land is exposed to the delivery of uncontrolled streams. The meadows below Iffley flood from 'The Weirs' and the Hinksey Stream; Osney fields from the Wytham stream, and Port Meadow from Medley and the mill-stream above Godstow. Medley Weir is wholly drawn in winter flood: Osney and Sandford Weirs were reconstructed I 884: Iffley Weir is in process of reconstruction ( 1922 ).

The last great flood (Nov. 1894) was the expression of excessive autumnal rainfall. Floods at the melting of the snow in spring are less usual (Feb. 1900). More rarely excessive rainfall may produce floods in May and June (1903). Medley Weir was wholly drawn, and meadows of the Upper Cherwell under water in August 1922. The record flood of 1894 , at Iffley Lock, rose to a maximum of 2 ft. 9 in. above Head Water, or 9 in. over the lock-edge and towpath. Tail-water $9 \mathrm{ft}$. implies up to $3 \mathrm{ft}$. over the lower meadows for a wide area. Ecologically the flood, as falling within the period of winter-perennation, is now of minor importance, and tends to be less the more it is subject to control. A rushing torrent of water scours the bottom and sides of the stream, washing out rhizomes of Nuphar, Acorus, Sparganium, ctc.; these with quantities of stems, fruits and seeds of aquatics and subaquatics may be left as the water recedes as a conspicuous débris-line, extending in special cases (as above the locks) to the margin of the old alluvium. Spring floods may do considerable damage to crops in allotment-areas (Osney), and to the hay-harvest (June, 1903); the water rising after the grass was cut, and the crop left to blacken on the ground (Iffley fields). In Aug.1922 the field below the lock was cut with 2 inches of water standing in the bottom grass. The relation of the pasture flora to flood-distribution (e. g. Rumex, sp.) is open to investigation, as also the amount of silt in the flood-water as determining the fertility of the flood-meadows: but the general tendency is to eliminate all flooding as much as possible. 


\section{PRIMARY WOODLAND AND ITS DERIVATIVES}

What we are accustomed to call a tree is the typical plant of the modern land-surface, representing the response of plant-life to conditions of subaerial environment over a period of hundreds if not thousands of millions of years. Such trees, again, have not been created or evolved to suit the conditions of the land alone, but are essentially derivative and migrant to the land from an older order of submarine existence as seaweeds. Just, in fact, as man has persistently felt himself to be a stranger and sojourner on this world, because his body, being inherited in all essentials of structure, metabolism, and sense-organs from the oceanic Fish, is equally far from being constructed to suit subaerial conditions. That is to say, in the modern trec one sees the finished article of long ages of an evolution as long as our own, going back to the sea where all life as we know it began.

Given an autotrophic plant-organization, of branching shoot-system displaying photosynthetic laminae to air and incident light, growing-points with permanent meristem, and a system of secondary increase adding effective mechanical strength to resist the physical chances and movements of the medium,-it is evident that, under optimum conditions of temperature and light-supply, vegetation will continue to increase indefinitely on the area occupied, and be, in fact, practically immortal, since without senile decay. All these growth-factors having been evolved during submarine existence, the translation of plant-life to the land-surface does little more at first than continue such organization, and progressively adapt it to subaerial conditions.

Where conditions of sunlight, temperature, and the necessary watersupply, are at a maximum, plant-life is still dominant, and at its optimum. Thus tropical evergreen rain-forest is not only the primary station for higher plant-life on the land, but it is still constituted by the most highly specialized types of tree-vegetation, as a massed jungle of dominant and competitive plant-forms. ${ }^{1}$ Where the ground is fully occupied, such tree-growths can only obtain pre-eminence by outstripping their fellows in height. Hence upward extension is exaggerated in competition for favourable light-supply, which is a constant taking the year round. In the struggle to rise higher over adjacent competitors the arboreal form attains its full differentiation as 'high-forest' in 'close canopy'. Simultaneously with extension to higher levels of the atmosphere $(100-300 \mathrm{ft}$.), the massive trunk is evolved in response to the demand for resisting lateral displacement by the wind, and the effective support of the mass of the branches and foliage.

Such a generalized arborcal phase of plant-life is sufficiently familiar as a commonplace to the inhabitants of even this part of the world's surface, in the forms of indigenous woodland. For this the biologicai conditions require to be more clearly expressed, and the limitations of such a phase of vegetation more particularly defined. The actual amount of plant-life in aggregate mass possible on a given area is dependent on such factors as:-(I) the amount of solar energy falling on unit-area; (2) the amount of water available in the soil ; (3) the constitution of the substratum in relation to the supply of food-ions in solution ; $(4)$ the possibilities of seasonal change including effects of frost, drought, and storm. For example, in the general case of a suitable soil with sufficient mineral matter, particularly nitrogen and phosphorus-content in addition to the humus-remains of past

\footnotetext{
1 Schimper (1903), Plant-Geography, Eng. Trans., p. 304.
} 
generations of vegetation, the essential factors may be considered as :(I) the amount of available sunshine in the year as affecting the working energy ; (2) the degree of temperature as affecting the rate of metabolism; (3) the available water-supply which will include all inorganic foodsubstances. In the case of primary rain-forest in the tropics, these factors may be all at an optimum; but as different cases arise introducing new problems, when such factors fail individually or collectively, new types of vegetation are isolated as solving them more or less effectively. Thus in tropical forest with light and temperature at a maximum, plant-life can rise to the limit of these physical opportunities ; but water-supply is the determining factor. With diminished water-supply, the forest-growth fails, trees loosen canopy, may shed their leaves, present a seasonal response to alternation of wet and dry periods, and become dry deciduous forest, grading to fewer and fewer trees, and these with highly xerophytic adaptations for perennation over the dry spell. ${ }^{1}$

With extension to extra-tropical regions (latitudinal), as northward, light-supply is reduced, implying less work done in the year; temperature also reduces to the limit of frost and snow, further lowering the rate of metabolism. Trees, again, present reducing features, but water-supply remains the essential factor in determining the forest-growth, and so long as it is available canopy may be maintained.

Similarly altitudinal extension on tropical mountain ranges, with a limit at the snow-line, gives all effects of reduced temperature, but with undiminished insolation; and so long as water-supply is effective the trees persist.

Combination of the case of the deciduous forest passing northward, and of that on mountain ranges, gives the general case of northward migration of the trees of the indigenous flora; all with markedly reduced habit and reduced annual output, as the highly specialized end-terms of older phyla of a former tropical existence, now represented by predominantly deciduous types, working with a short season, and enduring the cold of the northern winter (frost-period), with the last relics on the northern mountains, suffering from all disadvantages at the limit of tree-life (Salix, Betula); but within the range of this country, still sufficing to give continuous forestformation, so long as soil is available and the water-supply permanent. ${ }^{2}$

From such general considerations it follows that, coming as it does within the zone of North Temperate deciduous forest, with full water-supply throughout the year, the entire area of the Oxford district was originally general woodland. The tree-types are now comparatively few, as the migrants of $\mathrm{N}$. Europe, in turn the strays and residual forms of older and more tropical series. Oak (Quercus pedunculata) is the predominant type, as the species (with allied $Q$. sessilifora) farthest north of a forest-race of trees still culminating on the forest-ranges of tropical mountains of S. Asia, ${ }^{3}$ and passing north at lofty elevation (I-2 miles) on the Himalaya; similarly associated in Hill Forest with Almus, Betula, Corylus, Carpinus, Faguis, Salix, Populus, as comparable residual types also passing farthest north of their series. Many of these are isolated generic monotypes, flowering in early spring in order to get seed matured within the year. Much the same applies to Ulmus montana and Fraxinus, as the last northern strays of essentially tropical families; in a lesser degree to Acer campestre; while Tilia, also a residual stray, and alien Castanea, still manage to produce some seed though only flowering at midsummer.

1 Schimper, loc. cit., p. 35 r.

2 Tansley (191 $\mathrm{r}$ ), Types of British Vegetation, p. 65.

3 Cf. Wallich (1830), Plantae Asiaticae Rariores, fig. 46, Quercus spicata with erect fruitingspike, $\mathrm{r} f \mathrm{f}$. long, with over roo acorns. 
The number of locally indigenous trees of high forest, as opposed to smaller forms of underwood, maintaining their position by natural reproduction, is extremely limited; possibly only half a dozen, as :-Oak, Ash, Wych Elm, Alder, Birch, Hornbeam, and not all of these are seen locally freely germinating from seed (Oak, Ash, Birch). Other large and familiar treeforms are of comparatively recent introduction, and imperfectly naturalized ; that is to say, always planted. Some of these may produce quantities of good seed (Sycamore, Horse-Chestnut, Walnut), others do not seed at all, or only rarely (Common Elm, Plane, Lombardy Poplar, Black Italian Poplar, Grey Poplar, many Willows). The same applies to the case of Conifers: Pinus sylvestris was indigenous, but is now only grown by planting, as also is Taxus. Spruce (Pieea excelsa) and Larch (Larixeuropaea) of Central Europe, may be largely planted, but do not always mature seed. Cedars rarcly do so. These again are Northern Conifers still attempting to mature seed in onc scason, a problem solved more successfully by Pinus, which goes farthest north, by taking two. In dealing with introduced forms, it must be noted that it is not so much a question of the successful growth of the individual, which determines its success as an ecological constituent of the flora, as its capacity for producing fertile seed, and ability to grow from such seed in competition with other plants. Failure in seed-maturation, or restriction of fertile secds below the amount required to counter-balance the normal wastage of the reproductive mechanism, is fatal to the race, and is the direct effect of a shortened working season with enfeebled light-supply, or lack of adjustment of the inherited periodicity of the plant to that of the climate.

Confirmation of such deductions as to the original forest-flora inay be scen in the phenomena of regression of cultivated land and pastures, when left derelict, to thcir original condition. Thus thorn-scrub ("thicket') gives place ultimatcly to woodland trees, as Ash and Oak in good ground, and in the water-meadows Salix (sp.), Almus, Fraxinus, and Populus grow freely in ditches and hedge-rows. In a short period the entire district would revert to general woodland, and there can be no doubt that the original state of the country was that of the general forest of the central plain of England, much as first described in literature by Caesar, and left largely uncleared to the coming of the English, as locally a broad tract of swampforest, penetrated by water-courses, above which low wooded-hills emerged; the lower ground affording a tangled mass of vegetation, only swept clear by winter-floods, to which the land would soon revert if left vacant of human occupation.

By Neolithic man with a few domesticated animals, hill-clearings were made by fire, and valley-clearings similarly afforded pasture for sheep and cattle. The introduction of cattle implies the simultaneous introduction of many weeds and grasses of pasture-land, now passing as indigenous, but not found in woodland-clearings. But casual grazing will not keep land from regressing to scrub: constant firing was undoubtedly the oldest method of keeping the woodland in check, as it is still employed to keep down Gorse and Bracken, regressive thorn-scrub and brambles. Only in later times does the use of the scythe effectively produce the permanent pasture of grass-lands by annual mowings.

The first English settlers cleared the whole of the level alluvial tract, more or less submerged in winter-months, as grazing-land for their cattle fed in winter by the hay-crop, to the beginning of the rising ground. The latter they tilled for their own food-supply as corn; and cultivation spread up the low slopes of the hills, leaving the tops still covered with wooded caps, and the valley-slopes dotted with small holdings. The complete clearing of the alluvial flats as water-meadows, was the essential factor in the colonization of 
the neighbourhood, as ultimately of the subsequent progression of the city. These meadows are retained to the present day, as their liability to flooding in winter, and exceptionally even in early summer, precludes their utilization for any other purpose, until the level can be raised (cf. Port Meadow and Osney allotments).

Further diminution of the wooded-area followed increasing local and urban demands for fuel. Small copses were retained in the agricultural area. Derelict land, too wet on a clay bottom, too dry on upper clay, or too steep on hill-sides, was left to such woodland as it might carry. Broader areas of woodland, long retained as common land, have been enclosed, and now little remains of the original general forest-formation save tracts more or less 'forested' or 'preserved', as Bagley Wood, Wytham Wood, Stow Wood, and a multitude of minor copses, as marked scattered on the map. The tops of adjacent hills have been largely cleared, although all appear capable of carrying woodland. Cumnor Hurst has been cleared by fire, Shotover mainly by cultivation; the only suggestively dry hill-tract is the northern end of Garsington Hill, now under arable land, with but few trees in the hedges.

Residual Woodland, in whatever condition it may have been forested, on land which has apparently never known the plough, may be traced on Oxford Clay in Marley Wood, Wytham, Studley, Stanton St. John, Noke Wood, Water Perry, and Headington Wick; on Kimeridge Clay in Bagley IVood, Sandford Brake, Brasenose Wood; on Greensand in Hen Wood; on Calcareous Grit in Tubney Wood and Stow Wood.

Origin of Underwood: In high tropical forest of primal order there is no underwood. The canopy is dense, the lofty trees may be wreathed with liana climbers, and gay with high zones of epiphytes, but the ground is bare. ${ }^{1}$ Following the extension of forest to dry and extra-tropical regions with reduced or seasonal water-supply, the canopy is thinned, and increased competition for water leads to the relegation of many arboreal forms to a lower zone of underwood, as smaller trees, still woody and arborcal in habit, but scarcely worthy of the name of timber-tree, in all degrees of diameter and size of woody stem, to the smallest woody shrubs in the poorer classes of forest. This production of smaller, apparently dwarfed forms, is, however, not entirely a phenomenon of reduction, or mere deterioration of vegctative habit. The latter somatic feature is correlated with an advance in reproductive specialization, as these small trees flower and fruit at an earlier stage, giving quicker returns, and so have no need to attain the full size of the older type of tree. It is clear that this idea carried to excess, will give smaller shrubs which may even flower the first year of their growth, and continue to flower and fruit for many succeeding years. Few trees of high forest do this; the age-limit for flowering being largely determined by the fact that the bulky soma with great root-penetration, at last reaches the limit of balancing its proteid-synthesis with its photosynthetic capacity, beyond which excess carbohydrate becomes a nuisance, and may be eliminated in spore-production and the seed-stage. In such case, trees may be said to reach a certain adult phase; comparatively little growth is added once the fruiting-period is reached, and parasitic seed-stages drain the parent organism of superfluous material. A period of $30-5^{\circ}$ years is commonly required by,forest-trees to reach this point, and it is evident that any gain on such a time-limit will prove advantageous in hastening on the race.

Such small trees and bush-forms become relatively more numerous as the high forest deteriorates; and hence in northern woods will be abundant. They constitute a characteristic feature of English woodland; the more so as the flowers may be conspicuous and decorative as insect-pollinated mechanisms of considerable elaboration, or the fruits are gaily coloured and 
bird-dispersed. So far, it will be noticed that the great majority of indigenous trees of high-forest are anemophilous (Oak, Beech, Alder), and bear wind-dispersed seeds (Ash, Poplar, Hornbeam, Pinus) : Ulmus and Castanea retain inferior insect-pollinated mechanisms, but may fall back on wind: Tilia, Acer Pseudoplatauns, Aesculus, are later introductions producing beepollinated flowers. Many forest-types characteristic of the deteriorated woodland of this country are really underwood forms (Hornbeam, Acer campestre, Hasel, Salix caprca, Holly, Hawthorn), and it is difficult to draw any very exact line.

As the more characteristic types of underwood may be taken :

Crataegus monogyna (Hawthorn). Pyrus Aucuparia (Mountain Ash). Euonymus europaens (Spindle Tree). Prunus spinosa (Blackthorn).

Pyrus Malus (Crab-apple).

Ligusitrum z'ulgare (Privet).

Mex Aquifolium (Holly).

Sambucus nigra (Elder).

Viburnum Lantana (Wayfaring Tree).

Viburnum Opulus (Guelder Rose).
Cornus sanguinea (Dogwood).

Salix caprea (Broad-leaved Sallow).

Salix cinerea (Sallow).

Hedera Helix (Ivy).

Clematis Vitalba.

Lonicera Periclynenum (Honeysuckle).

Viscum album (Mistletoe).

Rhamnus catharticus (Buckthorn).

Rosa canina (Dog Rose).

Rubus fruticosus (Brambles).

All these have insect-pollinated flowers, and (with the exception of Clematis and Salix) bird-dispersed fruits. The fact that they are conspicuous and widely known is indicated by their English appellations, as familar woodland forms. As aliens of similar grade may be added Symphoricarpus raccmosus (Snowberry), Prumus Laurocerasus (Cherry Laurel), Rhododendron, Buxus, and planted species of Salix, Acer, Crataegus, Pyrus, Cotoneaster. Similar types, as general favourites in garden cultivation, are Laburnum, Euonymus japonicus, Viburnum Tinus, Crataegus Pyracantha, Spiraea (sp.), Rhus typhina, Syringa vulgaris (Lilac), Weigelia, Buddleia, Philadelphus, etc., as scheduled in forists' catalogues.

Such small trees arc rarely more than a foot in diameter (Acer campestre, Holly, Pyrus Malus), and range to an inch or less (Rosa, Rubus), in which case new shoots are thrown up with a growth of $I-2$ seasons only. Smaller trees follow similar lines of progression to shrubs and woody undergrowth, including woody lianas and sub-herbaceous climbers. The empirical criterion of such a shrub-type is taken as one which carries a woody stem, increasing year by year with a definite cambium giving annual rings of wood. Other features of somatic deterioration may be contributory causes; half a dozen may be mentioned. The essential feature of the somatic organization of a tree-type of high forest is its strong vertically growing main axis, carrying a great leaf-area to incident light, in competition with its fellows. This involves the co-operation of several distinct mechanisms, as (I) Dominance of the main axis over laterals; (2) Marked negative geotropism; (3) Active cambial increase ; (4) Effective mechanical tissues ; (5) Intercalary internodal extension; (6) Deep-sinking root-system (positively geotropic). Under stress of competition for light, water, and substratum, some weak point will develop, and plants may fail in any or in all of these respects. Those falling behind may develop compensatory equipment which may enable the race to carry on in a feebler condition, or the problem may be solved in some other way.

Elegant applications of the rule are seen in the progression of underwood shrubs and herbaccous plants. With diminution in the dominance of the main axis, the laterals increase in development, the cffect of concentration on the primary stem is lost, a shrubby bush-habit supervenes, and the latter may be effective in xeromorphic habit on a smaller scale (Broom, 


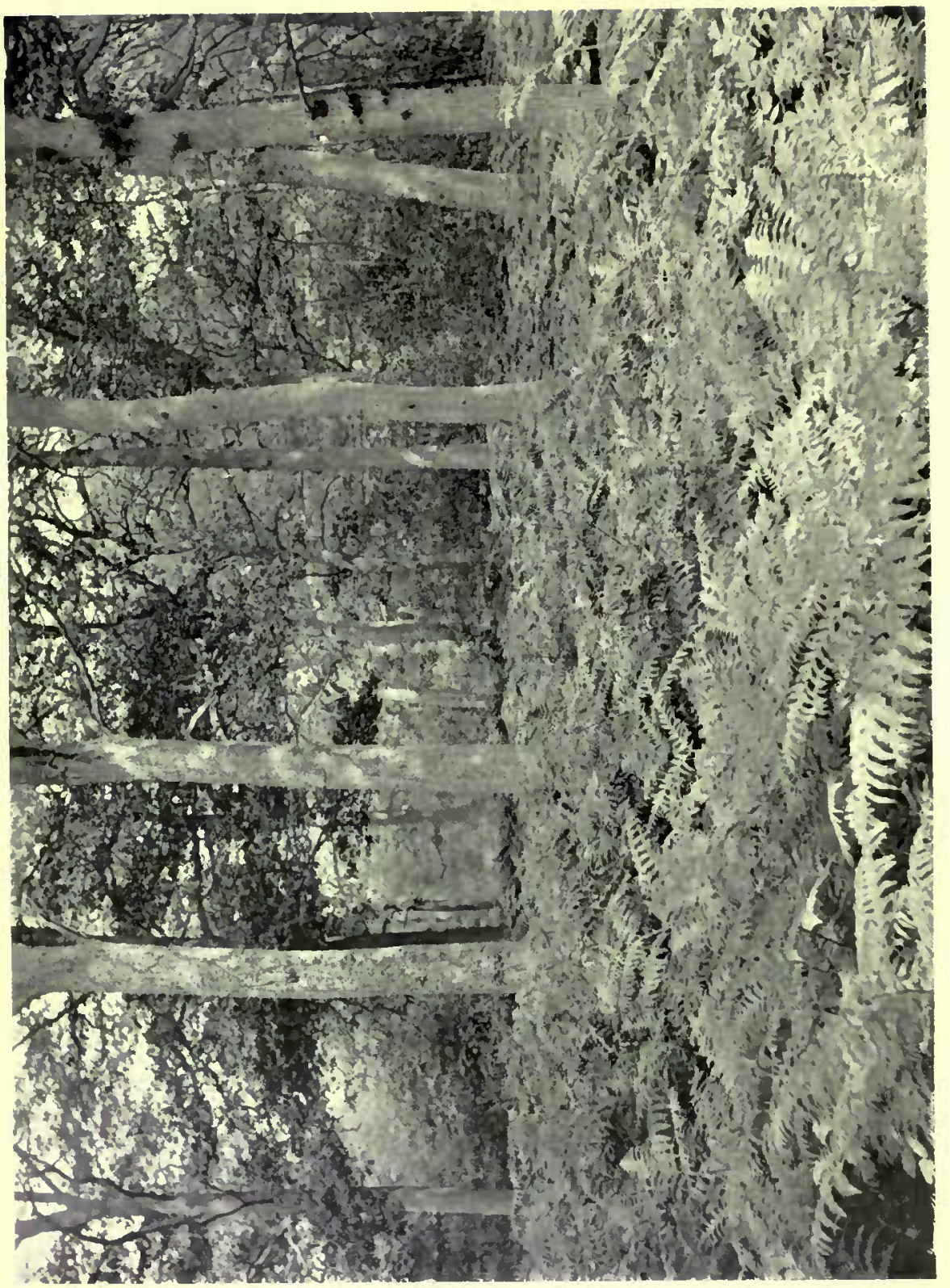

舟

$\frac{1}{4}$

$\stackrel{2}{2}$

三

8

직 


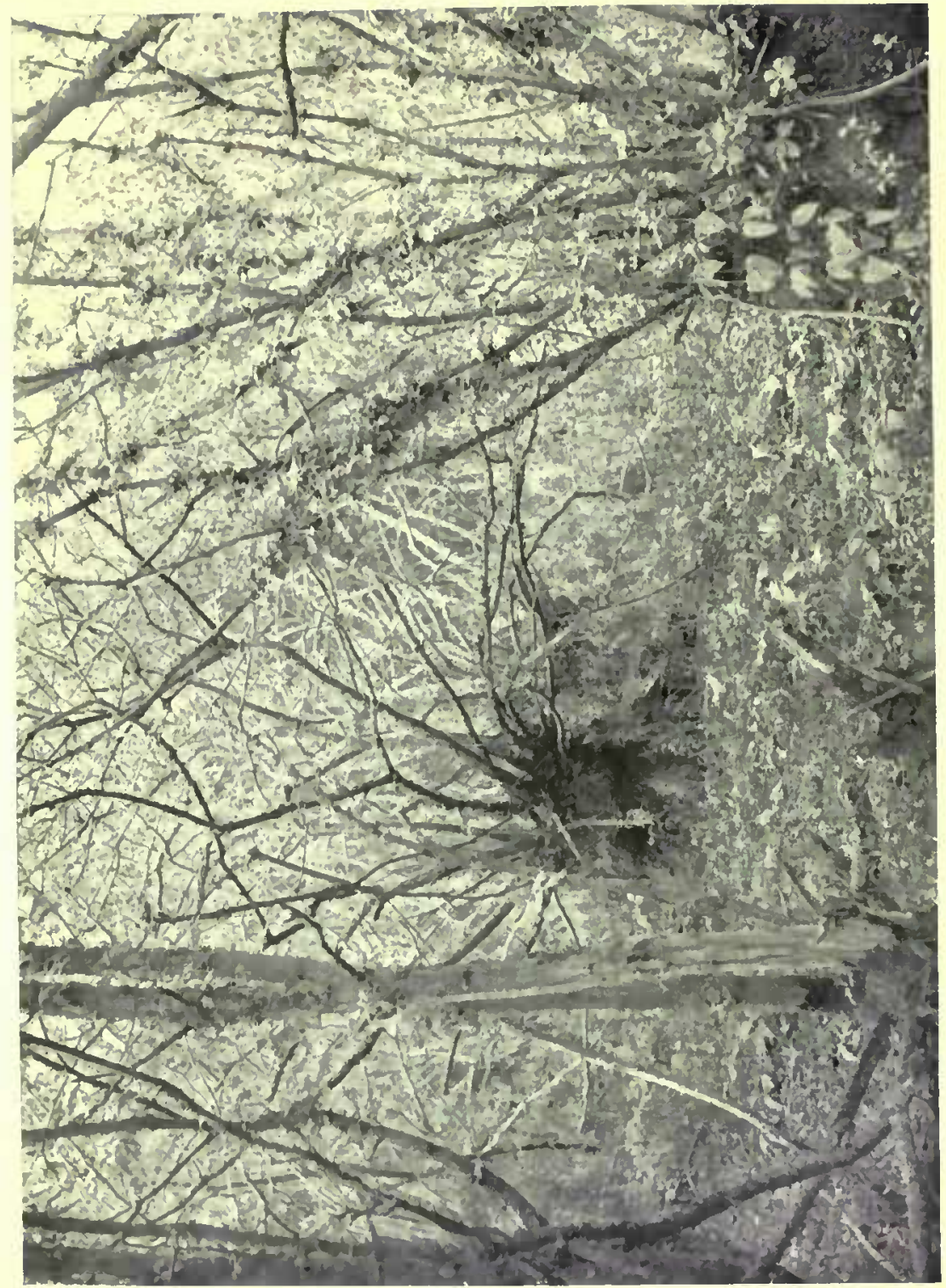

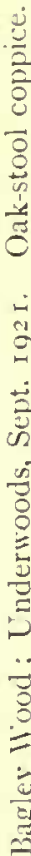

in 
Gorse). Loss of negative geotropism tends to production of flexuous shoots, the prostrate habit, and even to the case of the twining liana utilizing a compensatory mechanism of transverse geotropism. Reduction of intercalary extension gives the dwarf-habit, in the limit the rosette-habit. Of the common types of woodland, Corylus shows the deteriorated root-system : Hedera, a climber with weak stem, shows a compensatory development of adventitious roots : Lonicera is a feebly twining woody liana-form : Clematis, more effective as a woody liana, climbs by means of irritable leaf-petioles : Rosa becomes a scrambler by stem-spines : Rubus is even more flexuous, or prostrate with the shoots freely rooting at the ends. The point is to see that all plants with such equipment are at bottom forest-tree failures, making the best of second-rate somatic equipment, which, when compensated by greater efficiency in reproductive organization (insect-pollination, birddispersal), so lessens the problem of wastage, that the type as a whole becomes more highly organized, since continuing to give good results in more difficult surroundings. However racially specialized, the underwood tree, the shrub, the liana, and ultimately the herbaceous perennial, have all been derived by secondary adaptations from a primal forest-tree type ; and there seems to be no way of escaping this conclusion. ${ }^{1}$ From another standpoint all such derivative forms are regarded as deteriorated, so far as they are less fitted to dominate the stations with optimum conditions, which called forth their ancestors, though such stations are still available and are occupied by their more successful contemporaries.

\section{SUBORDINATE AND HERBACEOUS FLORA}

It is important to realize that any theory of evolution which records survival and success, also takes cognizance of decadence and failure; and any analysis of the factors making for the former implies an equal necessity for the consideration of the possibilities and effects of the latter; as each such factor may fail individually, or in association with others. In fact, peculiar sympathy may be said to attach to failure, since every individual organism which lives on this world is a failure, more or less, since it inevitably dies. But failure in one respect may open up new avenues of progression in others, and thus the facts of the main evolution of plants under optimum conditions are open to a wide range of variation and alteration as the conditions of life are themselves changed. Thus, in a lofty tropical rain-forest, where all the factors for vegetable growth are at an optimum, trees compete with one another, and many fail where a few succeed. Beyond the range of such a forest, with diminished value in the complex of external conditions, the struggle becomes more intense as the conditions become the more unfavourable, until the main fight concentrates against the environment rather than against other organism. As already indicated, the essential structural factors for tree-dominance, are (I) the specialization of a mechanically efficient main axis, carrying the weight of the plantsystem, (2) considerable internodal extension, giving height, (3) strong negative geotropism in the growing apex, maintaining vertical orientation. Where any, or all of these fail, the arboreal type deteriorates; e.g., to a small tree if insufficiently massive; to a shrub, if the main stem loses its

1 That is to say, it is not so easy to read the story the other way, and to trace the dominance of the long-lived slowly-malnring tree as the result of the specialization of factors possessed in a rudimentary condition by the herbaceous perennial; since the forest-tree is not the most paying proposition biologically, and some reason has to be given for the initiation of the corresponding structural characters seen in the smaller plant. 
leadership; to a scrambling or prostrate shoot-system, where the negative geotropism fails. Again, among a mass of competing trees, the primary struggle is to secure some sort of substratum, implying a connexion with the soil and its food-salt supply. Failures can only become attached to other organisms, as (I) Parasites, (2) Epiphytes, (3) Climbers, or (4) live as Saprophytes on decaying débris at the forest base. Parasites, making vicarious haustorial connexion with the transpiration-current of their host, may retain the woody habit. Climbers, utilizing the possibilities of inflorescence-tendrils, leaf-tendrils, root-attachment, or a special mechanism of transverse geotropism giving the twining habit, may remain arboreal to a limited extent. But Saprophytes, losing their photosynthetic mechanism (holosaphrophytes), are never woody, and Epiphytes only acquire the arboreal habit as their roots reach down to the soil. For example, the source of essential phosphate for an epiphytic orchid, living possibly $200 \mathrm{ft}$. high up on the branch of a tree, must be precarious to the last degree. Again, in such a closed formation, one wonders what becomes of all the output of seeds by the dominant trees; but even in the best regulated forest there are chances of accident, the largest trees must fail and fall at some time; tempest, lightning, and even earthquakes, may have to be reckoned with. So that even if the entire forest be demolished, provision for immediate regeneration has to be kept in reserve, as a necessary part of the wastage-problem of the race. Every optimum tropical forest thus carries its normally associated equipment of such forest-tree failures.

In more open forest, with the introduction of the deciduous habit, and less favourable conditions for tree-development, reduced shrubs and herbaceous forms acquire a new significance; and the latter, having served so long an apprenticeship to starvation, may now live and reproduce on the food-material gained in a shorter season than can a tree. In this way, as the conditions for tree-growth become more unfavourable, the herbaceous perennial acquires a greater preponderance in the flora. That is to say, even the optimum forest must come to an end somewhere; in space, as the conditions of soil and temperature change for the worse, and by time-factors, as seasonal extremes become more and more marked. Hence, though throughout all the ages, the evolutionary progression of the forest-tree is the main theme of Botany, there has been always a constant stream of phyletic débris of such races, which, failing in the full arboreal habit, may nevertheless make a working-success of some alternative line of existence. It is, in fact, the special property of the intensive energizing action of plasmic matter, which we call 'Life', to respond in the course of time to every possibility of environmental complex; and since we, as a human race, have left the tropical forest-zone, the more inferior types of vegetative organism, as herbaceous plants which have also lost the arboreal habit (though in a different sense), appeal to us as more noteworthy in their solution of the many complex problems of extra-forest land.

Origin of Herbaceous Plants. The case of the plant which never makes more than the first year's wood, introduces the type which gives the greatest range of variety in all modern flora, as the one which carries the principle of quick returns to the seasonal limit of seed-production on special shoots of one year's growth, followed normally by exhaustion and death of these axes after fruiting; perennation being maintained by parts at the soil-level, or below ground, in a definite rhizome (root-stock) region, which may itself be even massive and woody, but does not commonly appear above ground. Such extreme changes may appear within the limits of a conventional genus; since generic characters are commonly founded on the reproductive (foral) mechanism, as involving more deeply seated factors of 
racial organization. They may be combined with any or all of the preceding features of somatic reduction observed in deteriorated arboreal forms. With the loss of the necessity for a rigid axis, mechanically efficient over many years, the cambial mechanism and that particular type of vascular structure may be even wholly lost. In the great majority of cases the herbaceous stem presents only vestigial traces of its former timber-production. From the rhizome, or lower portion of the plant, retained at the soillevel in safe perennation, annual shoots of photosynthetic value, ultimately flowering and fruiting out, are alone produced; or the main axis may be reduced by the loss of intercalary extension to a mere basal 'rosette'.

Somatically the herbaceous plant is in essentials only a greatly reduced and deteriorated version of the original arboreal form from which it came ; but reproductively it has gained enormously in efficiency. A big body is after all of no use in itself except as providing a large supply of food-material on a grand scale. With increased efficiency of floral mechanism, seedformation, and seed-dispersal to new ground, the wastage-problem may be so successfully compensated that such vast spore and seed-output is no longer requisite. The machine becomes more efficient as more economical. The more a plant is enabled to withstand the disadvantage of a short working-season (following reduction of water-supply, light, or temperature), and the quicker it returns its seed-output, the more highly organized is the racial mechanism, and the higher the type in the scale of organization. Evolution measures races against races, not individuals against individuals.

So long as the plant can dominate the environment under optimum biological conditions, however short they may be in point of time (seasonally), and endure perennation during an alternating period of stress, the latter is forgotten in the high degree of activity and specialization of the former; just as an organism which sleeps to live with renewed activity on waking, is regarded as more highly advanced in the scheme of life, than one which never sleeps because it never works at an intensive rate. The introduction of an intensive time-factor, as tending to get a move on in evolution, is the thing which greatly counts.

From this standpoint, the herbaceous perennials of extra-forest zones represent one of the crowning phases of modern vegetation, and phases of somatic reduction may be carried to extremes. Absence of cambial increase, associated with the restriction of stems to annual duration, may end in the suppression of all vascular construction. Want of mechanical tissue again leads to a prostrate or creeping habit, which is further emphasized by change of geotropic response. While omission of intercalary extension may give a rosette-habit, extreme development of this factor, combined with preceding reduction-effects, gives the 'runner' and 'stolon' of the rhizomatous habit. On the other hand, the fact that all these factors may be retained in the erected inflorescence and floral axes, shot up as miniature arboreal growths for the function of flowering and fruiting, indicates that their suppression in the herbaceous perennial, with a limiting case in the creeping underground rhizome, is still wholly secondary; and again implies a very special habit adapted to the needs of a special type of vegetation, rather than being a 'primitive' condition.

The special value of the Herbaceous Perennial in the scheme of plantlife, consists in the fact that it can occupy stations available for some part of the year, where large trees cannot maintain existence through the extremes of the seasonal changes. It represents the highly specialized response to extreme seasonal change, with short working-period, when sunlight and water-supply may be at an optimum; hence in the shortened season of a northern climate, herbaceous representatives of many families compete on 
morc equal terms with the vestigial tree-types of underwood, as a dense mat of growth at the forest-base, occupying all available substratum, and taking the chances of light-supply and water-supply, to ultimately form associations with the larger growths. Though it is evident that they would do still better in more favourable stations, if the competing and dominant trees were removed.

Enduring a wider range of vicissitudes of biological environment, such herbaceous perennials come into further relation with the associated intensive insect-life of similar seasonal activity; hence the flowers are predominantly insect-pollinated, while the seeds are more admirably fitted to withstand the rigours of the perennation-period, commonly materialized as extreme desiccation of extra-forest region, and so tend to acquire a degree of vitality far beyond that of the older woodland tree-especially those of damp forest which are not required to dry off at all, and commonly possess little vitality when once dried (Oak, Walnut, Aesculus, Salix).

Such types constitute the bulk of the Flora of the North Temperate cxtra-forest zone, and are largcly represented in indigenous flora by many genera and species, espccially of such families as Cruciferae, Caryophyllaceae, Ranunculaceae, Leguminosae, Umbelliferae, Labiatae, Scrophulariaceae, Compositae, Gramineac, Cyperaceae, as representative families of Herbaceous attainment. Locally some 500 plants come under this heading in the wild flora, as well as a great range of forms in field and gardencultivation, as the most familiar flowers of arable land and pasturc, hedges and woodland clearings, where vicissitudes of the environment are at a maximum, and the working-period may be favourable for but $2-3$ months in the ycar.

Annual Plants and Ephemerals. All the considerations drawn from the case of the Herbaceous Perennial apply with increased force to the special. case of the herbaceous monocarpic plant which presents the limiting specialization as response to seasonal effects in the production of the 'monocarpic' habit, with onc flowering and fruiting period in the life of the individual. The soma docs not perennate after once fruiting, but dies of exhaustion in abundant sced-production, with no residual shoots to carry on growth in a subsequent scason. The seed-stage, that is to say, remains allsufficing for effective perennation, as the seed-stage may be specialized to withstand the greatest range and duration of desiccation, heat, and cold. This, however, implies the necessity of open ground for germination, and the annual is of little value in occupied woodland or a closed formation, save in clearings or on the death of larger organisms involving subjacent vegetation in their decay. Beyond the forest-zone annuals stand a good chance in the immediate occupation of ground in which normal perennials cannot even perennate, whether from extreme drought or extreme cold. In such cases early maturity and rapid seed-production alone gives them superiority over the herbaceous perennial; as the latter in turn went one better than the woodland tree. Such monocarpic plants are so far the most highly organized representatives of the plant-kingdom, running parallel with the extreme development of the insect-life of the land, in exact response to the same seasonal range of the yearly period. The annual plant, again, becomes the type so commonly exploited by man, as giving a crop, which may be sown, harvested and cleared, with the provision of unoccupied ground for its successor, in minimum time. ${ }^{1}$

Variations on the theme occur, as :-

(I) The Ephemeral, for which an even shorter period of optimum con-

1 Cf. 'Ten Week Stocks' of garden cultivation, and a local race of Barley formerly harvested 9-10 weeks from sowing (Plot, I 705, p. I 55). 
ditions, repeated $2-3$ times within the year, may suffice to produce the seeds of a new generation; an extreme case characteristic of several common weeds.

(2) The Bicnnial, or two-season plant, in which the short duration of the annual working-season may be compensated by a perennation-phase over the first winter, with postponement of the fruiting stage to the second summer ; affording incidentally an admirable case for exploitation of stored reserves at the end of the first season.

(3) In more tropical regions, with no frost, but xerophytic endurance of long-continued drought, such monocarpic plants may extend their working-period over many short vegetative seasons, and finally fruit out on an intensive scale; but no examples of this type occur in indigenous flora, so that its occasional observation in garden-cultivation (cf. Agave) attracts attention.

Effective methods of herbaceous perennation, originally the response to conditions of extreme desiccation over a dry season, may prove equally cfficacious against the extremes of Climate, as expressed in exposure to cold winds at great elevation, or to the cold and wet of a dark Northern winter. Hence in a North Temperate clinsate the herbaceous perennials of a warmer region, with acquired effective perennation mechanism (especially in the extreme form of rhizome-extension ${ }^{1}$ below the frost level, or by the attainment of marked annual periodicity) may grow in a short hot summer in a manner recalling the vegetation of even a tropical aspect. The latter is the general experience of garden-cultivation in this country (cf. Helianthus anmuns, Zca Mais, Cucurbita Pepo, Ricinus, Nicotiana); but even in indigenous flora the last strays of essentially tropical types may extend northward as woodland forms, the last representatives of their special lines, commonly presenting other extreme phases of somatic or biological organization. Cf. Cuscuta, holoparasite and annual; Calystegia, the most sensitive indigenous stem-twiner, rhizomatous; Bryonia, rhizomatous, and the most perfect tendril-climber ; Tamus, rhizomatous, and a twining Monocotyledon; also the last residual Orchids (Platyanthera, moth-pollinated, Listera, fly-pollinated) of epiphytic origin.

An interesting case of the water-problem is seen in the herbaceous Xerophytcs which vegetate in early spring to flower during the hottest period of the year, often with extreme xeromorphic adaptations against loss of available water, as spinous Thistles, Dipsacus, hairy and glandular Labiates, succulents of walls and stony places (Sedum, Sempervirum), as also the plants of roadsides and waste débris, enduring more concentrated soilsolutions (Chenopodium album, Polygonum aviculare, and the originally halophytic Beets and Mangel).

All degrees of complexity obtain, as what is commonly isolated as apparently a special modification to one end, may more or less satisfactorily solve several distinct problems; so that plants cannot be accurately or mechanically graded. One adaptation may play into others according to edaphic changes, as well as climatic. A mechanism of perennation, originated in response to extreme drought, may be equally effective against loss of absorptive function in cold wet soil. Plants originating as special types of dry stations with minimum water-supply, may endure swamp-conditions which imply reduced root-activity. In this way xerophytes may apparently grow as hygrophytes; and the latter if they can invent a method of checking excessive transpiration, may be found in xerophytic stations. (Cf. Iris of sandy deserts and Iris-Pseudaconis of the ditch-side; Polygonum amphibium flowering as an aquatic, and vegetating in dry sandy pastures; Equisetum

1 Cf. Hop, Rhubarb, Rumex Hydrolapathum, Bryonia, Asparagus, Calystegia. 
ariense and $E$. Telmateia of the swamp, also intrusive in pastures, arable fields and hedges).

Not only may species of the same genus show range of type from shrub to herbaceous perennial, or from perennial to biennial or annual, according to features of somatic organization, or time-factors of the reproductive period, but in the same genus representative or complementary species commonly diverge to different biological lines or stations, as xerophytes $v$. subaquatics, summer-flowering $\%$. spring-flowering, climbers $v$. non-climbers, etc. ; since. as already noted, natural relationship is expressed in the more fundamental features of racial mechanism traced in the details of the reproductive processes, and seen most readily in the floral structures rather than in the vegetative shoot-system.

To sum up, the general case of the progression of the Herbaceous Xerophyte is sufficiently familiar, as its response to the necessities of a short season cuts its working history down to the stage of the biennial, annual, or even 'ephemeral', or leads to a multiseasonal and monocarpic habit. The vegetative shoot-construction has lost its woody texture, the shoot-system is specially adapted to perennate over the dry season in rosette or rhizome-form. In the limit, the subterranean rhizome, with its special cases of corms, tubers, and bulbs, affords a familiar example of getting beneath the surface of the protective soil and stopping there; while in the short favourable part of the year the reproductive system may long tend to repeat, as far as possible, in its inflorescence-axis, the original erect branching habit of the arboreal prototype. Under these conditions, the flowers may retain an organization as fully efficient, quite as 'primitive', or' even more suggestively 'elementary' and archaic than those of any foresttree (cf. Hellebonts, Aquilcgia, with Magnolia and Liriodendron). The same mechanism which is effective during heat-perennation, is usually also cfficacious for cold and frost-perennation (espccially once wcll below the surface of the ground), and the perennation-problen is so far unificd. The active life of the plant, including more especially its reproductive cycle, is thus condensed within the limit of the favourable growth-period, as determined more particularly by the possible water-supply.

Given the sunlight and temperature of any part of the world in tropical to temperate regions, the critical factor in determining the range of forestcanopy is the question of adequate water-supply, - whether at some time too litile, as expressed in low rainfall, in impervious soil, extreme cvaporation, rocky ground, etc., or too much, tending to swamp arcas insufficiently aerated, muddy bottoms with no holding ground, grading to decp and open water of standing ponds, streams, lakes, and cven rivers in which the current introduces an additional factor. To the former case belong the wide range of reduced herbaceous types conveniently classed as Xerophytes; ${ }^{1}$ to the latter lies open an cqually wide scope of adaptation to conditions of aquatic cnvironment, in which the essential water-problem no longer obtains, though temperature and light in the end become limiting factors.

Of all such reduced herbaceous flora, adapting their shoot-mechanisms to these conditions, the rhizomatons type is perhaps the most interesting; since with the prostrate habit, and loss of negative geotropism in the vegetative shoots, together with the retention of the possibility of intercalary cxtension (or even with practically none at all), there remains a definite mechanism for lateral transportation, which is beyond the power of the normal ancestral tree. With this capacity for lateral extension and adventitious rooting, such types of vegetation can travel in the course of time considerable distances, with the chance of finding conditions more suit-

ischimper (1903), Plant Geography, p. 3. 
able for their existence. This same faculty for lateral progression has again a wide application in the attainment of a gregarions habit; e. g., in covering soil with a mantle of protective vegetation on the part of xerophytes, or in travelling towards the source of water in facultative aquatics. All aquatics have apparently passed through this phase. In all cases the gregarious habit initiates a new form of canopy, preferably indicated as a 'mantle' or 'mat'-formation, and the individual organisms acquire a certain amount of control of their special environment by collective action, which again puts them on a higher plane. ${ }^{1}$

The case of the Aquatic is more complex, since the water-problem so insistent in the general case of the land-plant is largely eliminated; perennation is restricted to periods of winter-cold and darkness, only in the limit to the possibility of the total disappearance of the water. But even in the growing season temperature is largely regulated by that of the water, which shows relatively little range, and may be widely different from that of the air ; while the aeration problem of the submerged portion becomes critical, since the free oxygen-supply is at best only $\frac{1}{2}$ per cent. by volume, as compared with the 20 per cent. of the free atmosphere. No aquatic can make good in the water until it has solved the problem of aerating the submerged root-system by which it absorbs its food-salts, by means of an exaggeration of the system of intercellular spaces, and the retention of the waste $\mathrm{O}_{2}$ of photosynthesis. As this method is the best thing the plant can $\mathrm{do}^{2}{ }^{2}$ but is never wholly a success, the root-system remains permanently handicapped. Its absorptive capacity is strictly limited, with consequent result on the reduced transpiration system, as exhibited in the further deterioration of all vascular tissue, and restricting the supply of essential food-salts. Water-plants become characteristically starved, pulpy and parenchymatous, with lacunar tissue, and little mechanical efficiency beyond the maintenance of the turgidity of the active cell-units with abundant and cheap water-content.

On the other hand, since protoplasm is itself a medium containing over $9 \circ$ per cent. water, it is evident that while no effective plant-life can ever flourish under extreme xerophytic conditions, however intensive it may be during its short spell of active growth, the aquatic environment is clearly the original one for all plant-life, and such regression to the water may open up new possibilities. Since the water-problem, which is after all the most difficult proposition for all land-flora, is now largely discounted, so long as the water itself is available, it remains only a matter of difficulty for the parts which are out of the medium; and such plants return to the water armed with their age-long experience as seed-plants of the land, and are now on a new footing in their old environment.

The case of the Facultative Aquatic, as that of a rhizomatous plant rooted in the ground, and following failing water-supply, enduring submergence, or even floating on the surface, but without any special anatomical adaptations ior aeration, remains wholly incidental. The story of the Obligate Aquatic begins with the plant rooted in subaqueous ground, and supplying oxygen to its root-system from the over-water green shoots. To such a plant the amount of water present begins to be a secondary consideration. The vegetative parts grow above the surface to reach air and light, and the flowering shoots may retain much of their original erect branching habit, with flowers of primitive or even highly elaborated organization, on a par with that of the xerophyte of a short season, or of actual forest-trees. In

1 For such possibilities of invasive action by gregarious rhizomatous forms residual from types of tropical organization, cf. the case of Urtica dioica (Sting Nettle) of the Urticaceae, that of Mercurialis as the last elementary type of the Euphorbiaceae farthest north, and the remarkable specialization of Pleris aquilina (Bracken) as the preponderant indigenous fern.

2 Schimper (1903), loc. cit., p. 25. 
such rhizomatous forms, once the rhizome-habit has been attained by the loss of the normal factors of arboreal growth in the main stem, the capacity for geotropic erection and internodal elongation may be retained to a certain extent, while the orientation and display of the foliage laminae may be still the prerogative of the leaf-petioles.

I. Hence the First Phase of the Obligate Aquatic ${ }^{1}$ is that of a herbaceous plant, with rhizome rooted in the mud of a woodland swamp-area, sending up erect leafy axes subsequently to produce flowers and fruits in free air, in the normal manner of woodland undergrowth, but already characterized by a feebly-absorbing root-system. In damp air the shoot-system may retain fairly normal construction; but in more open situations xeromorphic features begin to be shown, as the leaves tend to lose water faster than they can take it up; and shoots with greatly reduced foliage-members become characteristic. In this respect it is interesting to compare the limiting reduction of Equisetum (Horsetail) of the Pteridophyta, with its leaves reduced to merest points, and photosynthesis entirely restricted to the green shoots, with the Angiosperm Hippuris (Mare's Tail), the latter with greatly reduced leaves on the subacrial shoots, and minute inconspicuous flowers: again as expressing the fact that progression in aquatic habit is by no means a factor of time. A certain level of attainment, once established, may be so maintained indefinitely and unchanged, so long as the plant may so come to occupy an 'inferior' station in which there is little competition. Equisetum, as the typical aquatic of this category, is at the same time one of the oldest known typcs of Land-flora, as a greatly deteriorated representative of a race that was arborcal as Calamites of the Palaeozoic, and probably beyond: Hippuris, a seed-plant of the more modern epoch, does not get so far in shoot-reduction and specialization, though curiously similar in general dimensions and whorled habit, but other Angiosperms go far further.

II. So long as the shoot-system can elongate above the water-level, and the roots can obtain free oxygen from the over-water parts, no specially new problem arises; but where the stem remains wholly submerged, reduced to a prostrate dorsiventral rhizone, or bearing terminal rosettes of leaves, the entire onus of the ercction and display of the foliage members in the air, falls on the leaf-petioles and the leaf-lamina itself. Where again the rhizomatous plants are closely gregarious, occupying all the substratum available, lateral extension will be precluded, vertical elongation is the only solution, and competition sets in for the production of a new close-canopy of elongated leaf-members, giving the characteristic 'Rush-habit' (Sparganium, Acoms, Iris, Butomus). In such case the 'spearing' habit of the young leaves to reach the surface is enormously exaggerated; and in the production of an crect linear leaf-member the distinction between petiole and lamina may practically disappear. ${ }^{3}$

1 The case of the Aquatic requires more extended notice, not only because aquatic vegetation is particularly well displayed in the local flora of swamp-woodland and river-system; but while the shrub and the herbaceous types of the woodland show with sufficient clearness their reduction from the arboreal habit, the general effect of much of the aquatic vegetation (especially Monocotyledonons forms) is only remotely suggestive of a tree-organization. Resemblances are traced in details of anatomy rather than in general morphology. A sequence of types is therefore arranged to illustrate the more complele adaptation to an aquatic environment secondarily, in correlation with progressive loss of original arboreal mechanism. To read the story the other way, as a rise of Angiosperms to the land from comparable modern aquatics, involves some account of the manner in which such structural features as main axes (cambium, timber) could bave been evolved from originally wholly submerged aqnatics.

'Sparganium ramosum is the typical 'Rush' of Rush baskets, Rush ma1s, and Rush-seated chairs, as a valued economic plant of older times. Fragrant Rushes for strewing on floors were Acorus Calamus (leaves), and the Rushes of Rushlights Funcus effusus, flowering axes.

Schimper (1903), Plan! Geography, p. 810, Isoëtes-type. Arber (1918), The Phyllode Theory of the Monocotyledonous Leaf, Annals of Botany, xxxii, p. $4^{6} 5$. 
III. Where in turn such mechanism of orientation and erection in the petioles wholly fails, the leaves droop, to float passively on the surface of the water. With such relief from all necessity of mechanical support and also from the possibility of desiccation, new possibilities open up for what may be termed the anchored floating leaf. In fact so many problems are solved by the adoption of passively floating leaves, that their anatomical organization is modified to meet the new conditions; e.g., restriction of stomata to the upper surface is readily effected when they were originally on both sides. Such floating leaves become characteristic of a wide range of aquatics, from facultative grasses to more particularly highly specialized types of Dicotyledons. To such leaves increase of surface is essential, as they lie in the horizontal plane only, and the plant becomes 2-dimensional so far as its photosynthetic area is concerned; while the available space becomes more restricted as rhizomes are condensed and the plants are gregarious. The leaves spread out to enlarged sub-orbicular form, with leafmosaic on the water-surface, soon occupying all the room available; but capable of indefinite extension in open water so long as it is of no great depth. The mechanism of petiolar extension gives the regulation of the lamina to the depth of the water and its position in the leaf-mosaic, and this becomes a limiting factor: e.g., Nymphaea alba may grow in $20 \mathrm{ft}$. of water. Such a depth of water is beyond the capacity of any tree-type, and beyond the preceding aquatic habit; so that the floating leaf opens up a new field of operation to plant-forms, in which they are beyond the competition of the older types of the land. In thus finding a ' new station' in the water, plants are not necessarily 'driven off the land'; the latter expression remains metaphorical as a poetic exaggeration of the facts, merely because we remain on the land ourselves. ${ }^{1}$ It is difficult now to visualize what such a fine plant as the Victoria regia of the Amazon may have been before it left the land.

IV. It may be noted that such petiolar mechanism has again its limitations ; it cannot be extended indefinitely, and it does not meet the case of casual alterations in the water-level, or seasonal periodicity of the supply. That is to say, its failure may be expected; e.g., at the beginning of the growing period, or at the end of the season, many leaf-laminae may fail to reach the surface at all. In such case a new type of submerged leaf may come into action; and where this proves efficient for photosynthesis a new set of structural alterations may be called into operation. When so apparently withdrawn beneath the surface, the photosynthetic area is no longer 2-dimensional in the horizontal plane, nor does it require to be vertically elongated as in the rush-type. The necessity for the orbicular leaf vanishes, though a linear form may still be useful where it lies in the flow of the current. The plant-body again becomes 3 -dimensional, taking all the light it can receive; the more so as effective light diminishes rapidly in intensity beneath the surface of the water. Stomata are no longer required; normal transpiration is no longer effective; the plant-form tends to regain an algalhabit. Leaf-laminae reduce to thin crumpled expansions, or are dissected to fine filamentous segments which space themselves in the medium, with no special mechanical difficulties, admitting any light they do not use to the members beneath them, and retaining in their reduction the pattern of the

1 Arber (1920), Water Plants, p. 324. Emigrants leaving this country for the colonies may be said to be similarly 'driven out' by financial, social, political, or theological pressure; but they leave of their own free will; they are by no means the leavings of the population; but on the contrary, are distinguished by their greater enterprise in the search for new stations. The criterion of success is adaptability to new conditions; the non-adaptable are the real failures; and by adaptability is now understood a capacity for freely mntating under the stimulus of a new environment. The rest is left to natural selection. 
bundle-distribution of the older leaves of the land in skeleton-form. In such manner the wholly submerged shoot becomes free of water to any depth, so long as light-penetration is sufficiently good (i. e., in clean water) ; and streams and lakes fill up with subaqueous vegetation, imitating in its dense ramification the vegetation of the subaerial world, and recalling in such retained form-factors the older vegetation of the sea, in which such structural features were originally established in response to the necessities of a moving medium. Though now so essentially distinct in acquired anatomy of the land-plant, the general appearance of such submerged aquatics is curiously algal, in dimensions as well as in texture (cf. Potamoge ton lucens in a strong current, $P$. pectinatus, $P$. crispus, Myriophyllum and Ranunculus fuitans as $6 \mathrm{ft}$. trails).

V. All aquatics so far mentioned remain attached to the bottom, and are so far anchored, even when wholly submerged in the manner of benthic algae, and they may grow in deep water, if this is only sufficiently clear. ${ }^{1}$ Yet here, again, the mechanism of attachment by adventitious roots is the essential factor: where this fails, the plants are set free to rise to the surface in virtue of photosynthetic oxygen, to become free-floating vegetation, solving the problem of optimum surface, but left free to drift at the mercy of current and wind, and with a feebler absorption system than ever beforc. Such a new type of vegetation can attain no great dominance, any more than do free-floating algal forms of the sea. ${ }^{2}$ Flotation depends entirely on oxygen storage; sinking in deep water may be fatal; only by remaining at the surface, and eliminating chances of drift (by gregarious mass-effects) can any benefit be gained. Thus the minor types of plant which have adopted this life, tend to imitate the broad expansions of the leaf of 'floating aquatics' (Lemna, Hydrocharis), while others are little advanced beyond submerged forms (Elodea, Lemna trisulca). The dilution of the food-solution, the diminution of transpiration in forms floating in rather than on the water, and the feeble capacity for absorption, tend to ultimate stages of reduction, which render some of these forms (cf. Wolffia) the most diminutive of Flowering Plants. ${ }^{3}$

VI. It is important to note that, so far, the general construction of the vegetative and photosynthetic shoot-system has been alone considered; but similar conditions of failure may characterize the portion of the shootsystem set apart for reproductive functions, as special inflorescence-region of the plant, inflorescence-axis, and even flower, wholly independently. The two regions of the plant-body are not exactly on the same footing, and have to meet quite distinct problems : since the vegetative portion has to bear the onus of obtaining the food-supplies, while the reproductive shoot with its cycle of reproductive phases may be restricted to the more favourable period of the year. As a rule, the reproductive portion will be found to be more 'conservative', to retain much more evidence of the older phase of land organization, and to lag behind the advancing specialization of the photosynthetic leaves. The flowering scheme of an aquatic has little reference to what its leafy shoots may be doing, and throughout the range of

1 Cf. Schimper (1903). Plant Geography, P. 792, for Posidonia in the Mediterranean at 30-50 fathoms.

${ }_{3}^{3}$ Pistia and Eichornia as free-floating forms of tropical rivers become pests, as the gregarions habit gives them a stationary character. Cf. Arber (I920), p. 213 .

3 These classes are by no means exhanstive, and types grade into one another even in the ontogeny of a single individual; that is to say a certain range of plasticily in the organism may obtain. Jatrachian Ranunculi may produce both 'broadened' floating leaves and 'dissected' submerged laminae on the same shoot. Sagiltaria with normally erected subaerial 'arrow' leaves in rnshhabit, in deeper water gives arrow-forms broadening and floating on the surface, and in still deeper water the attenuated ribbon-petiole $(6 \mathrm{ft}$.). Free foating forms are commonly mud-plants with little holdfast. 
aquatic type, the original multibranched inflorescence-axis, erected from the water, affords a conspicuous example of this capacity for the retention of older machinery of the land (Sparganium, Hottonia, Utricularia). Reduction of such a compound subaerial inflorescence-system follows rules similar to those of land-forms; problems of size of floral mechanism, anemophily, and seed-output, may reduce or modify the constructions to simple spikes, or ultimately to single flowers. These, again, may be affected by the relation of the mechanism of adjustment of the floral axes or inflorescence axes to the depth of the water, in the manner of petioles; and further effects are observed as such axes may retain photosynthetic mechanism in the manner of petioles. Thus in plants with the rush-habit in leaf-members, a comparable rush-habit may be attained in the inflorescence axis (Butomus), and such axes (culms) may be left as subaerial shoots when the leaves are submerged (Scirpus lacustris). Types with floating leaves may similarly attain adjusted surface-floating flowers (Nymphaea); but in an older phase these were not so accurately managed and stood clear of the water (Nuphar, Limnanthemum). In the limit, forms with submerged leaves may also fall back on submerged flowers (Potamogeton densus, Zostera), and pollination in the water may replace anemophily; but even in submerged aquatics the projection of the flower-spike above the surface is more usually arranged for (Potamogeton luccns, Hottonia, Batrachian Ranunculi). The two systems of foliage shoot and reproductive shoot require to be kept quite distinct, as are their essential functions and problems. ${ }^{1}$

Such different types of plant-form, ranging from the timber-tree of high forest to the lowliest free-floating aquatic, collectively constitute the Angiosperm fiora of the present world. Every tropical forest contains its dominant evergreen forest-trees, with subsidiary associated epiphytes, parasites, saprophytes, and climbers (lianas); each of these exhausting in turn the possibilities of the new station and new mode of life they have found, and growing in active competition with the main crop of trees, as the full ecological equipment of such a forest-formation. All deciduous forest, similarly, may retain examples of these primary and secondary constituents of the optimum forest, with added tertiary formation of minor trees and shrubs, as also a greater wealth of herbaceous ground-flora constituting the underwood and woodland base. Open land beyond the forest zone is given over to xerophytes, rock-plants, and prairie-forms; swampy woodland and water-courses supply all ranges of aquatics, rush-types, floating, and submerged forms. Angiosperms, as the modern dominant race of plant-forms, culminating far beyond the older Pteridophyta of the first land-surface, have by this time invaded all the available biological stations of the world. ${ }^{2}$ These stations present a mixed Angiosperm flora which is the effective solution of the special biological problems of the environment, taking into consideration the past history of the race, and the way it has come, as originally seed-producing trees of high tropical forest. That is to say, the story of plant-life can be only read one way. Given a tree-phylum and the world to itself, there can be little doubt that in the course of time, its descendants would be found modified to suit the biological conditions of every special station, very much in the manner that plants do now. In ancient times, preceding races of vegetation have pursued much the same course, indicating that the general conditions have not greatly changed. A few relics of the world of Pteridophyta in Pre-Palaeozoic times

1 Cf. Arber (I920), loc. cit., p. 6.

2 Just as in the parallel animal kingdom, Reptiles once dominated the land-surface, Mammals do now, with aerial Bats, regressive marine Cetacea, fruit-eating monkeys, tree-eating elephants, grass-eating deer and cattle, as well as carnivorous, insectivorous, herbivorous lines, all making up the animal equipment of a continental area of woodland and prairie, river and sea. 
are left, as Reed-types (Equisetum), free-floating (Azolla), saprophytic (Psilotum), xerophytic, epiphytic, and climbing (Lycopodium, Selaginella, Lygodium), while their prototypes of high forest have vanished, or only remain in the form of coal. Similarly at the present day, convergence in biological habit, or association in the same ecological station, is no indication of 'affinity' or relationship. Existing families of Angiosperms may be as remotely related as are the few residual types of Pteridophyta. Some families are now left predominantly aquatic, others may be predominantly or solely forest-trees; others are now almost wholly herbaceous. The flora of every country containing the essential biological stations is a complex of the surviving protagonists, similarly specialized for their special problems, along many lines of remote affinity. In all parts of the world the association of similarly modified plant-forms in corresponding biological formations gives a certain facies to the partial flora, which is distinctive; though the actual forms concerned may be phyletically wholly distinct, and making the best in their own way of what equipment they may have inherited.

The British Flora, as the deteriorated representative of deciduous forest-land remote from the tropics, affords a wide range of biological stations, woodland, open ground, and aquatic environment. It thus presents a complex in which there is room for something of everything: all biological lines are represented, even if only by one or two forms in an attenuated scheme. It still retains a few evergreen trees, now sub-dominant to the main series of deciduous forest-forms. Underwood trees and shrubs are well represented, with not only an abundant ground-flora, but a few residual representatives of the secondary vegetation of the tropical forest as parasites, epiphytes, saprophytes and liana-climbers. Open exposed ground beyond the woodland area, gives an abundant variety of xerophytes in hot summer: short-season plants mingle with the grasses of prairie-land; all grades of aquatic are met with in swamp-woodland, ditch, and open river. The flora as a whole includes a series of samples, as the country itself affords a wide series of samples of climate, geological formation, and botanical stations. ${ }^{\text {? }}$

So far, again, no special reference has been made to the remaining vegetation of older cpochs in the evolution of the modern plant-kingdom, as illustrated in the few residual Gymnosperms, the feeble representatives of Pteridophyta, the wider range of Bryophyta (Mosses), and the numerous and varied representatives of the still older range of Algae of freshwater (including Plankton-forms), and their saprophytic homologues of the land (as Fungi and Lichens). These are left for future consideration. The more conspicuous and dominant forms of the modern flora have the first claim; this being the more emphasized by the fact that there is no evidence that the full progression has taken place in this country, or through the intermediary of any such archaic types. All are equally immigrant, and owe their special characteristics to conditions of environment in probably far distant lands.

Owing to the local predominance of swamp conditions in the older Oxford Valley, the progression of water-plants becomes of special interest, as superimposed on the organization of the herbaceous forms of woodland and woodland-swamp, introducing factors which are new rather than regressive. But the general trend of events is so far outlined. Though there may be indefinite breaks in the story of any given plant, as well as divergence in special variations of the different problems, and it is understood that the progression took place largely elsewhere before exten- 
sion to this part of the world, the general sequence of events is so far outlined, and it should be sufficiently clear that :-

(I) Every aquatic of the open stream once grew on the bank. ${ }^{1}$

(2) Every bank-aquatic was once a plant of damp woodland undergrowth. ${ }^{2}$

(3) Every plant of swamp-woodland was once in normal woodland as a herbaceous perennial.

(4) Every herbaceous perennial was once an underwood shrub.

(5) Every underwood shrub was once a tree of high-forest.

Each stage in such progression calls for further detailed analysis; but the present object is to show that the story is unified, and hangs together. A local flora is not a collection of disjointed units, or phases of special creation, but one progressive whole, in which each part has its proper value and status. This is what is implied by the evolutionary" and ecological standpoint.

The advanced submcrged obligate aquatic is perhaps the type furthest removed from the primary forest-tree; and just as the tree-type rcquired to invent and specialize its arboreal factors from the horizon of a transmigrant seaweed, so these factors are gradually lost in the herbaceous perennial on regression to water as a rhizomatous form, or are retained as vestigia, to be last discerned in the floral shoots and details of the floral mechanism of reproduction. It is necessary to have some working hypothesis in tracing such a progression, and the foregoing assumptions are based on the causal factors of light and water-supply as bearing on the nutrition of the individual,- the loss of primary arboreal factors being compensated by precocity of flowcring and fruiting, with increasing specialization in the mechanisms of cross-pollination and seed-dispersal, as also of increased vitality in perennation. Conversely, while it appears possible to trace the progression of the obligate aquatic, by the loss of all arboreal factors, there is little evidence that such a series will evcr work backwards all the way, or that the full type of a forest-tree has been cver derived from such aquatic vegctation. The story of the Flowering Plant (or Angiosperm) is restricted to primary forest-forms, the origin of which from necessarily smaller types of transmigrant vegetation appears at present hopelessly beyond recall; though the existence of primary land-plants in the herbaceous form may be indicated at the older horizons of Bryophyta and possibly Pteridophyta.

It seems a far cry from the Duckweed of a standing pond to a timbertree of high tropical forest; since the time required for such a transition is beyond our perception, once it is granted that there is no reason to believe that the rate of progressive evolution has been ever greater than it is at the present day. A period of a thousand years makes no appreciable difference either in climatic conditions, or on the indigenous flora. The December frost of 1142 was recorded as a phenomenon, and was no more intense than that of March I 895. The vegetation was essentially the same in woodland and any valley-pastures in Roman and Neolithic times; and it has been wholly renewed since the last maximum of Glacial cold. The time since the post-glacial river-terraces were begun must be reckoned in hundreds of thousands of years; when it is noted that the greater depth of the rivervalley was cut down apparently in milder epochs, with no marked snowfall, much as at the present day, with slow erosion and deposition of alluvium.

1 Since all (with the exception of Wolffia) retain roots as essentially soil-organs.

2 Rhizomes of many plants follow the water down the bank, to $3-6 \mathrm{ft}$. trails, extending into the water, or floating. Cf. Epilobium hirsutum, Potentilla reptans, Lycopus europaets, Polygonum amplibiztm, Agrostis stolonifera, in widely related families. 
This implies that the Pre-glacial period may have been quite 10 times as distant, or may be estimated in terms of a million. Yet, according to C. Reid, no less than 75 species $^{1}$ of the present flora were even then sufficiently cstablished to be fully recognizable; leaving the period required for their full establishment indefinitely remote. All these plants, again, had come to this country as migrants, specifically fixed and long-established; the place as well as the time of their origin is left open. Allowing a margin of error for such determinations, it begins to be evident that species, as they are now reckoned, must go back at least to the Tertiary. If genera became broken into modern specific forms in the Tertiary, for which a time-distance of something like 50-100 millions has been claimed, Families of still older order may date back to the Cretaceous; as in turn the primary lines of divergence between Gymnosperms and Angiosperms may be of Palaeozoic antiquity (some 300-400 millions). The fact that forest timber-trees (Cordaitineae) were in existence in the Upper-Devonian, indicates the immensity of the gap still required to account for the rise of a timber-tree, producing flowers and seeds, from the algal prototypes of the transmigration, ${ }^{2}$ and the possibly hundreds of millions of years required to build the organization of the arboreal habit from its constituent factors.

\section{THE HAND OF MAN}

Of all influences which have been brought to bear on the character of the flora up to the present time, that of human agency is overwhelmingly preponderant, and the more disturbing as it is often erratic in action and bearing consequences wholly unforeseen. Little objection can be taken to such influences by the naturalist, however much he may pine for a virgin forest at his door, since it is only by such human interference that the locality has been made available for human life in the first instance, and to it we owe the fact that we are here at all to examine what is left of the original condition.

Without going back to the remote ages when the mammoth came down to drink at the river-terraces, ${ }^{3}$ or the reindeer and woolly rhinoceros wandered over the site of the city, it is clear that even at the beginning of the historical epoch the land was covered with dense forest, in which roamed wolves, wild boar, and red-deer; the forest-canopy being only broken on the exposed more arid slopes of some of the adjacent hills, and again in broad stretches of swampy ground formed by the damming up of the river in winter floodtime with its narrow outlet below Sandford. " In every type of floristic region the effect of human effort and interference is to be traced; not only as considerably modifying the nature of the ecological associations, but rendering them largely of temporary duration, liable to disturbance the effect of which is wholly incalculable at any time. Thus of the original Forest-land no trace remains in anything which may be regarded as approaching its primary condition. With clearings for arable and pasture-land extending over the slopes of the river-basins above the alluvial line, patches of woodland remain as Wytham Wood and Bagley Wood, each of an area extending to about a square mile. Smaller portions survive as copses (Radley Wood, Stow Wood,

1 C. Reid (1899), Origin of British Flora, p. I I .

2 Thalassiophyta and the Subaerial Transmigration, Bot. Mem. iii, I920.

3 Bones of Elephas primigenius were dug up in the gravel of Magdalen College Grove in 1921.

4 Traces of woodland extend practically to the top of Shotover; a few trees (Pine and Elm) grow on the exposed top of Cumnor Hurst. Forest-land deteriorated to Willow and Alder-scrub may come down to the alluvium near the present river (Godstow Holt). Only Wytham Great IVood, and more definitely Nuneham Woods, still come down to the river-margin. 
Wick Copse), more usually in the form of derelict land in which swampy conditions still prevail (Sandford Brake), or merely left as a convenient source of rough wood for minor agricultural purposes, faggots and firing. As the trees are cut down, and regeneration follows naturally from the old stools or by seeds, or more effectively by planting, the original arboreal flora is wholly replaced, and only the underwood remains in anything like its original condition; though in variety of species, again, this suffers rapid diminution, as smaller sections are more and more isolated, and the leafy canopy deteriorated. Extreme felling for timber and firewood leaves only thickets of thorn or coarse scrub on dry situations, or willow and elder-scrub in wet tracts. Other woods are allowed to run derelict with the undergrowth encouraged as subserving the protection of game.

The channels of the larger streams with their submerged and floating aquatic forms, and the vegetation of their banks merging gradually into the meadow and woodland associations adjacent to them, become subject to arbitrary change. The stream is artificially banked (with concrete), and the bed is dredged for ballast-gravel, or to deepen the navigable channel, to control the flood-water in winter, and pass it off as quickly as possible from low-lying levels, as well as scoured of weeds in summer. The main river is locked (with equipment of weirs, lock-gates, and lashers) in order to subserve transport, and with the effect of holding the water up over the dry summer in irrigation channels, and differentiating the land above the lock from that below. The bed of the navigable stream is subject to periodic cleaning of the weeds. The original aquatic flora is to be sought in backwaters, ditches, and smaller streams, often long uncontrolled, but again largely artificial, and liable to interference by extended systems of drainage, as 'swamp'-land becomes agriculturally 'improved' and taken into cultivation. In repair of lock-and weir-mechanism, whole sections of the main stream may be allowed temporarily to run out.

The broad water-meadows of the alluvial area are distinctly artificial, and the result of human activity, as these levels, cleared of casual trees and scrub, are laid down in pasture to be cut for hay each summer, with the effect of keeping down all attempts at colonization by woody and larger perennial growths, and thus relegated to grasses and the associated plants of meadowland; as again a very secondary selection of the plants normally characteristic of such localities, together with many intrusives and importations. In the water-meadows this effect is the more emphasized by the mowing of a second crop in September. Nor can it be claimed that the original fora persists unchanged in the ditches and hedges of the alluvial district. The ditches are artificial as drainage-systems, populated by a few stray aquatics brought by flood-water; neither standing ponds nor streams can be depended on as primary constituents, while the hedges with heaped and drained earth-banks are stations equally artificial, which freely regress to scrub, and so far carry vestiges and strays of more woodland habit; in both cases, again, supporting an enfeebled flora of a few common types, as they become the more isolated and remote from similar stations and the conditions more restricted, mingled with casual strays and the intrusive weeds of cultivation.

Of the land above the alluvium, cleared by early settlers, and now permanent pasture or under arable cultivation,--the pastures, close-cropped by cattle, become grass-land with intrusive weeds as thistles, thorns, briars, and nettles; and where, if kept down by mowing, these are more preponderant along the hedge-banks, the latter are again artificial productions as welldrained earth-banks of no great thickness, carrying a sparse population of bushes with a few trees whose roots alone penetrate deep into the subsoil. Such arboreal forms of residual underwood as hedgerow bushes afford shelter 
to birds which largely propagate them by berries (Hawthorn, Sloe, Elder, Viburnum, Rosa, Rubus, Privet, Honeysuckle, Bryonia, Solanum Dulcamara).

The arable-land, with improved methods of agriculture, becomes 'cleaner' and cleaner, with few weeds beyond those of cultivation, imported with foreig $\mathrm{n}$ seed and characteristically annuals and ephemerals, increasingly artificially selected as their life-period coincides with that of the crop concerned; each crop carrying its own special weeds. The business of an agriculturalist, in cultivating one or more special forms or races of plant for economic purposes, is, in fact, to clear out every other associated plant as a 'weed' which otherwise robs the crop of water and expensive manures.

The same standpoint reccives emphasis in the case of the allotment cultivation of vegetables, and the more select and aesthetic gardens growing decorative plants and florists' flowers, in which intrusive 'weeds' are kept down more or less rigorously as vulgar interlopers ; while a few plant-forms, often aesthetic monstrosities, are selected by human agency in a wholly erratic manner at the expense of the rest of the vegetable and animal kingdom. Allotment-holders arc bound by regulation to keep down their weeds.

The Willows which form so characteristic a feature of the margins of low-lying alluvial meadows, with their remarkable exhibition of epiphytic vegetation, owe the latter character, as also their special configuration, to the manner in which they are periodically pollarded; and the complex secondary vegetation recorded in one year may be wholly swept away as the trees are stripped to barcst stumps, the usual period being anything from 2-10 years. Abnormal effects also follow extreme lopping, as the plants are destroyed by Fungus-attack, ultimately reducing to hollow shells, variously split, with descending pillar-roots and hollow axis of touch-wood. Similar irregular growths under human maltreatment are seen in the stools of oak-coppice, and the deformities produced by continual cutting back and pollarding of trees in hedgerows, with often fantastic rcsults (Ash, Black Poplar, Elm). Normal epiphytic vegetation is extremely rarc, beyond the Mosses and Lichens of the underwood.'

Hence in every grade the study of the original flora of the district reveals its subordinatc status, and one has to endeavour to trace it to the causes which may have produced it beneath an entanglement of secondary effects of human interference, the actual agents of which not only display a supercilious manner in dealing with the deteriorated vestiges of the plantlife of the neighbourhood, but often express wonder at, if not pity for, those who consider the remains of such original vegetation worthy of more than a casual notice. To the forester, attempting to grow trees for commercial gain, the inferior vegetation is interesting only so far as it becomes a nuisance, or harbours fungus and insect-forms which may be migrant 'diseases' of his trecs. At best it is to be tolerated as protecting seedlings from the wind, conserving soil-moisture, or as a 'soil-indicator'. The agriculturalist, again, cannot conceive why to many the wild flowers of his hedges are more interesting than the crops of turnips and wheat in his fields; ${ }^{2}$ as the allotment-holder seldom thanks anybody for admiring the fine crops of injurious or imported weeds coming up among his cabbages or on his rubbish-heaps; while the floriculturalist who can control a garden 'without a single weed' is regarded as deserving of the highest compliment that can be paid him.

The effect of an increasing population in the immediate vicinity of a large

1 Polypodium vulgare alone has been found epiphytic on Beech-roots and on old Pear-trees.

2 For much of this contemptuous regard, the field-botanist of the last century is largely responsible. By hunting a farmer's fields for specimens of the British Flora, he put himself definitely on the side of the farmer's enemy (the weeds), instead of taking any interest in the prodnction of new strains of the agricultural crops. 


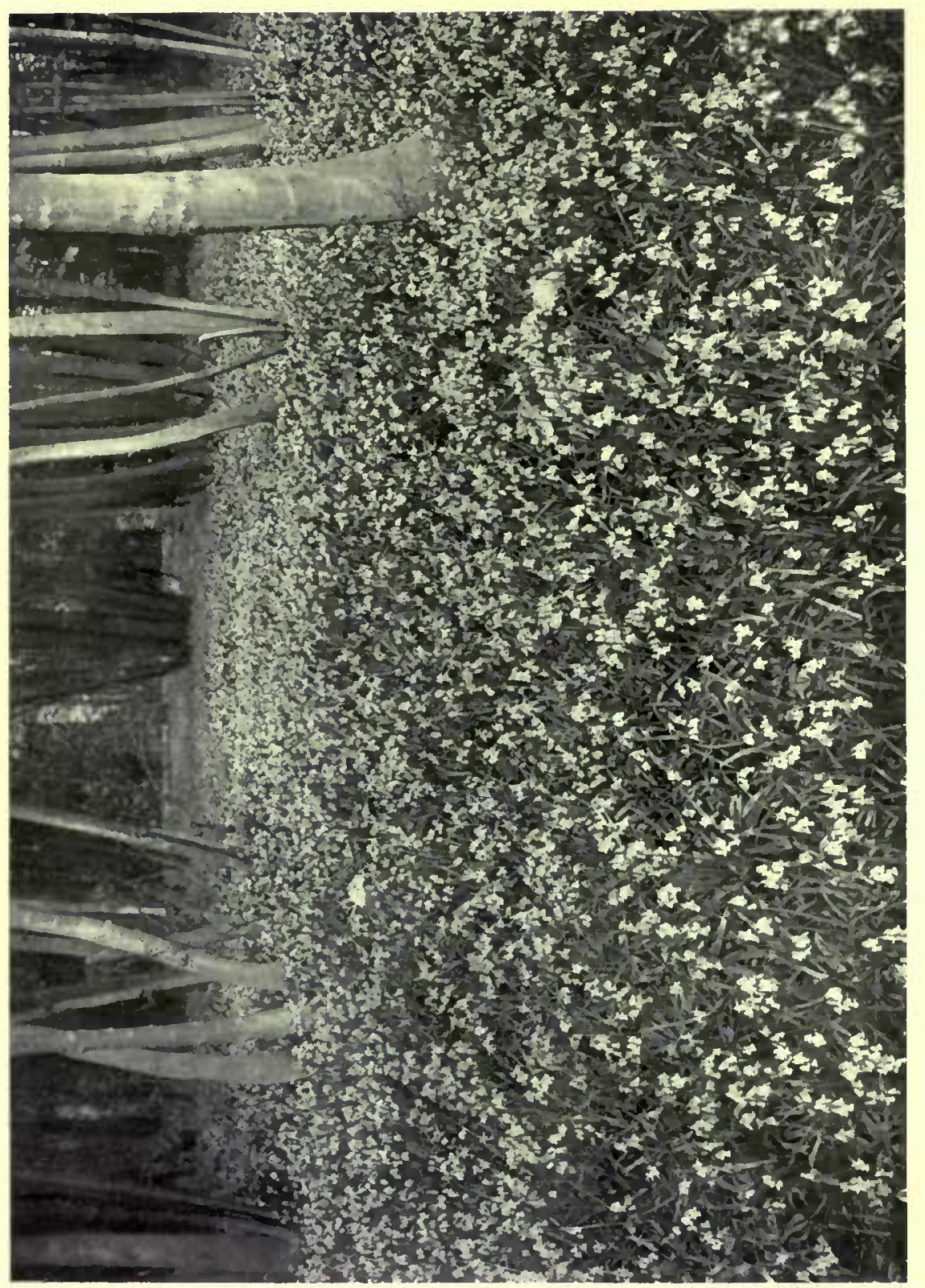

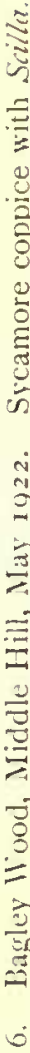




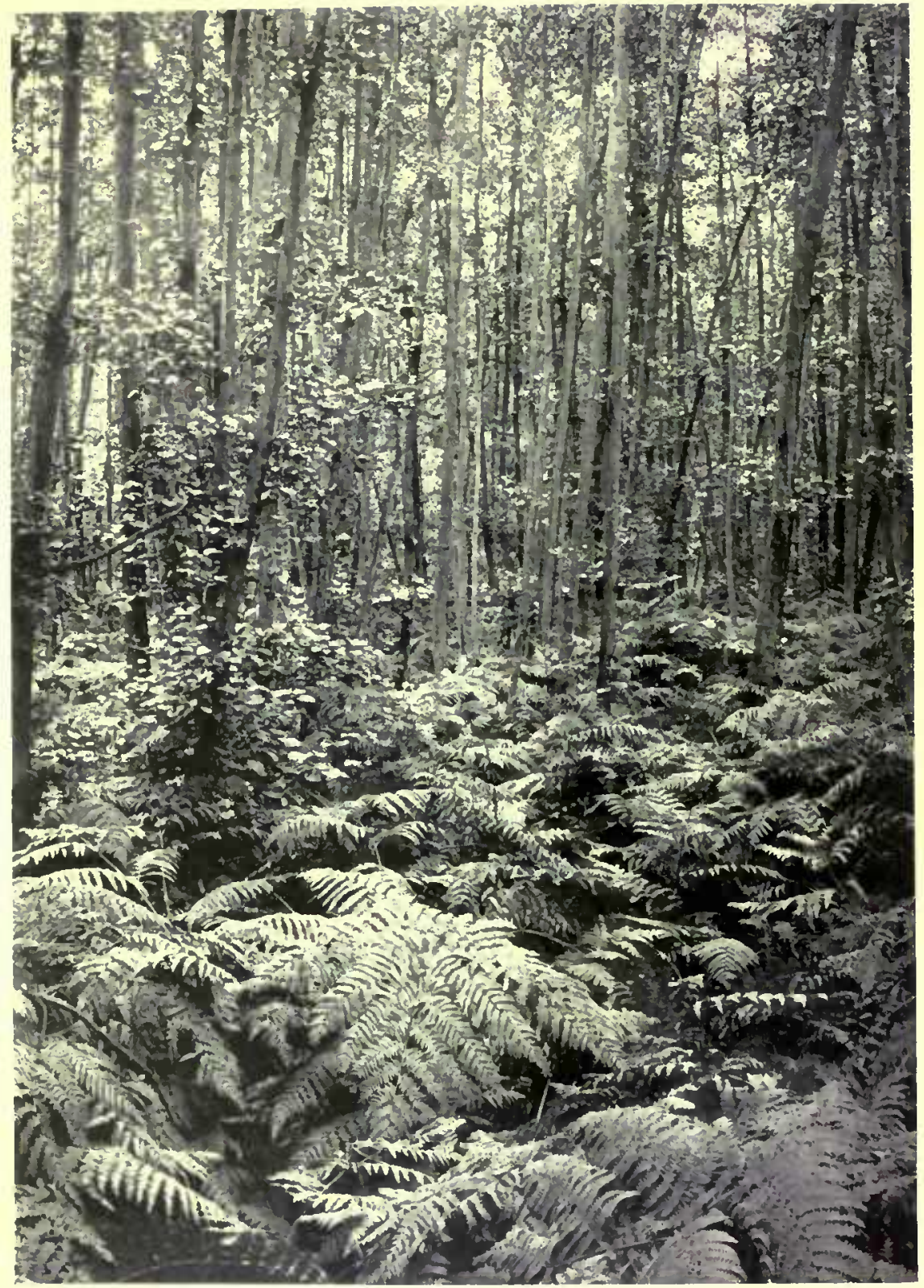

7. Bagley Wood, Aug. I922. Alder Coppice over Bracken. 
town naturally introduces much abuse of the local flora. Children, using the adjacent fields and by-ways as their natural playground in increasing numbers, carry out an active campaign of destruction on all plant-life within reach. Hedges are broken and trampled, more flowers are destroyed than picked; trees broken, rotten willows burnt out, aquatic vegetation damaged by sticks and stones, become the general characteristic of the fringe of the inhabited areas, together with a general devastation of attractive flowers wherever available. Such mischief on the part of children is normal, and no one grudges them the pleasure of picking nosegays of Buttercups and Daisies, Caltha, Fritillaria, Lychnis Flos-cuculi, Cardanine pratensis, Bluebells, Primroses, and Cowslips, or foraging for nuts and Blackberries, as these appear in quantity, since there is enough for all: but adults who should know better, with wider range, will equally devastate hedges and woodland, grabbing all available specimens of rarer flowers of aesthetic value for alleged decorative purposes, or expressing their delight at the return of spring-vegetation by stripping all in sight, as if the supply were inexhaustible. Collectors also show no compunction in taking any rare plant for their 'herbarium' or 'exchange'; hence rarities are ruled out of an ecological flora, however interesting they may be as vestigial survivals. Indigent wastrels, again, strip the countryside of flowers, fruits, and roots, as these may present some slight commercial value (Fritillaria, Typha, Fern-roots, Guelder-rose berries, Spindle-tree, and even Phragmites).

Everywhere within walking-distance of the town-area, general deterioration of the flora follows the effect of increasing population on cultivated and enclosed land. Hedges are broken by picnic-parties in search of fuel, and within recent times the holiday extension of Thursday afternoons has had an effect which parallels that of the Saturday holiday of the children. The extension of 'Summer-time' has had a further noticeable effect on the invasion of the countryside, and within the local district has emphasized the destructive effect of the school summer-holidays. In such case it is not surprising that the amount of agricultural and forest-land closed to the public steadily increases. Hedges are liberally mended with barbed wire, and notices bearing reference to the alleged fate of Trespassers meet one at every turn. The wandering botanist is naturally mistaken for a tramp off the beaten track, ${ }^{1}$ or for an officious inspector of something or other. Hence modern works on the flora can be eked out with floristic records of past ages, now unavailable and useless : to give the locality for a rare or interesting plant is to sign its death-warrant. As such changes are increasingly rapid in this generation, a record may be useful for future reference.

It may be admitted that the ever-increasing town-areas spread out as a canker eating into the life of the countryside, that it is the natural instinct of much of the human race to defile everything they come into contact with, to destroy or enslave every other form of life, with only the blindest ideas of improving their own. This is but the age-long story of natural selection and the relation of the animal to the plant,-the more obvious in a small district, owing to the ruin and damage readily effected by a few unscrupulous or ignorant agents, whose action, though deplored by their betters, remains unchecked. Local areas are bought up to prevent exploitation at the hands of the speculative builder, but the general public is ruled out or admitted uncontrolled. Nature-sensitives admiring the beauties of the local flora are not happy unless they can take away as much as they can carry with them; leaving behind in exchange ginger-beer bottles and orange-peel. Picnic-parties also trample the undergrowth, damaging fences and lighting fires. These restrictions are not confined to the district; they represent the general tendency of the age within all growing urban areas, and appear unavoidable.

1 'In hat of antique shape, and cloak of grey', Matthew Arnold. 
On this account it cannot be wondered at that the few remaining examples of woodland and waste, as well as cultivated fields, are becoming more and more closed against the public, and the favourite collecting-grounds of an older generation of botanists are destroyed or are no longer available. ${ }^{2}$ This applies more particularly to Wytham Wood, Hen Wood, Radley Wood, Bullingdon Bog, Magdalen Wood under Shotover.

Bagley Wood, closed to the public, is utilized for instructional purposes by the Schools of Forestry and Botany. It is interesting to watch the fate of the 30-acre University Enclosure on Shotover (I908), devoted to the use of the Public. ${ }^{2}$

In a short time the public will be restricted for floristic studies to the few foot-paths over fields still left open as old rights-of-way, the dusty or tarred roadside, the tow-path and the open river, with alluvial areas as Port Meadow, and Iffley Ficlds when these are not up for hay, or to their limited experiences as allotment-holders.

But there is another side to the story. The general aspect of a wellwooded countryside, even at its best, is but the effect of human activity and cultivation; however much the appearance of forest-and pasture-land may appear natural because it has been the same within living memory, or even historical record - it is by no means 'primitive'. Its very maintenance at the present condition requires careful prevision and active judgement on the part of the human population. Woodland, grown and cut under any sort of rotation, however vague, is not original forest. Pastures are maintained at their functional standard by definite and intentional care, grazing, mowing, and hedging. The very accessibility of the district, to say nothing of the admirable motor-bus service in recent times, is the effect of the maintenance of very modern roads and foot-paths, without which little could be done. One does not do much scientific work in a trackless jungle. Woodland paths, if not kept cut, become practically impassable in a few years. Derelict land runs to dense thickets, soon wholly impenetrable owing to thorns and briars, however admirably adapted to the modern necessities of boy-scouts.

The countryside as we know it is the wholly artificial product of a certain standard of human culture, and it is only maintained at a similar biological horizon by continued work. Once the hand of the farmer, forester, or gardener is relaxed, the effect is soon apparent. Primitive scrub, jungle,

1 Stow Wood, though much reduced in area ( 30 acres) is apparently still open by the courtesy of its owner, though the stereotyped minatory notice is attached to a conspicuons tree; and the same applies to Headington Wick (1922), as still a unique area. Horspath Common (Bluebell Valley) is still available, but 'Open' Magdalen is enclosed and wired, and 'Open' Brasenose, fenced I922, is apparently to be cleared. Pickett's Heath, with the 'Signal-elm' of Matthew Arnold's verse (I86I), has been completely derastated, thongh the tree remains.

2 A notice, remarkable for its auto-suggestion, reads: "This Piece of Gronnd is the Property of the University of Oxford. It is open to Visitors, but they are requested to refrain from pursuing the game, and catching Rabbits, from disturbing Birds' nests, Lighting fires, Plucking Flowers, Pulling up roots, Injuring the trees, the brushwood and the Fences. Offenders will be Prosecnted. By Order.' At the present time (1922), one looks in vain for game, there is no fence at all, the notice is damaged, the gate is gone, only the stout gate-posts defy removal; marks of fires are nnmerous, and a considerable portion was burnt $192 \mathrm{I}$.

Cf. Radley Old Wood (1922), 'Persons picking flowers or roots, or otherwise trespassing, will be Rigorously Prosecuted. No tickets issued.'

The conventional declaration that 'Trespassers will be prosecnted' is found at Magdalen Wood, Brasenose Wood, Coombe Wood, Sandford Brake Wood, Plowman's Copse, Tommy's Heath. Kailway Companies protect themselves by prescribing a 40 . fine for trespassing on the line, or leaving level-crossing gates nnlatched. The River under the guidance of the Thames Conservancy remains open; 'All persons using the River Thames, and the Locks, Works, and Towing Path thereof, must take them as they find them, and use them at their own risk." Unusual solicitude for the wayfarer is shown by a recent note $(I 922)$ - 'Persons undressing or dressing on or about the river, without shelter, render themselves liahle to be prosecuted." In comprehensive botanical interdict, however, the By-laws of the Thames Conservancy (1898), are by no means behind, and one is warned, among other things, "not on the river or banks or towing-path thereof, to do or cause or incite any other person to destroy or injure any flowering or of her plant, or any shrub vegetation tree-wood or nnderwood ', under a maximum penalty of 610 . 
and swamp are not inviting, nor would they repay much scientific examination. Ecological experiments pre-suppose some sort of control of the biological factors. Modern attempts at saving tracts of country as birdpreserves or sanctuaries for indigenous fauna and flora, however well-meaning, have no future value; any more than modern forestry with its serried rows of saplings will restore the Neolithic forest. Nothing in nature stands still. Just as one cannot restore the original condition of swamp-woodland in the Oxford Valley, with its necessitated human life in wattled huts on scanty diet, and would not do any scientific work if one did; so it is now equally impossible to maintain a wild jungle at one's door or in the back garden. The seeming wild is not so very wild after all ; the old English term 'waste' is peculiarly applicable. Any sort of selection, whether natural or artificial, implies the ultimate advantage of a few types at the expense of the others. The relations that have made the countryside what it is during the last $I, 500$ years represent the influence of a set of physical factors, as distinct from the original selection of nature in post-glacial times, as it is from the future still increasingly artificial selection of the farmer and forester. When townspeople bemoan the ruin of the country as they have seen it, or read about it in the past, it is only a change of ecological conditions that they are witnessing; whether better than any previous changes in the past, or not, may be left for the future to decide. The present time is one pre-eminently of transition and survival; it is the cause and the manner of the change which is the present centre of interest; though it may be admitted that the odds are usually on the side of pessimism.

As all floristic regions are thus entirely secondary and artificial in such fundamental features as water-supply, destruction by grazing, felling, draining, clearing, and direct human interference, it will be observed that:-

(I) The exact valuation of the indigenous flora becomes a matter of difficulty.

(2) The nature of the alien-flora, immigrant at various times, has to be reckoned with.

(3) No effects of succession can be traced beyond such cases as:-the drainage of a ditch, the replacement of meadow-land and pasture by allotments with their weeds of cultivation, or the effect of close-planting of forestplots on the flora of forest-clearings.

(4) No continuity of observation over a long-continued period can be guaranteed; at any time the association may be destroyed, removed, or cleared, by agencies beyond the control of the observer.

At any rate, one thing is clear,-with the removal of man and all his works, the flora would not take long in reverting to its original condition; and with man would go all his associated weeds and aliens, as well as his dependent food-plants, trees, and animal races. Possibly the whole efforts of human activity and so-called progress mark but an incident in the life of the indigenous flora. The latter was, in primary essentials, the same as it is now, 10,000 years ago: the boldest speculation can scarcely look forward to the probable status of the human population in 10,000 years time. But it is quite clear that if man is not here, the same old flora will be. Thus, damp woodland, if not forested, would become more or less impenetrable jungle (as in parts of Headington Wick). Neglected hill-pastures soon revert to thorn-scrub of the type seen in Headington Quarry-heaps. All arable fields, left to themselves, would follow suit, and become much as their hedgebanks. The green pastures of the water-meadows would be converted into willow and thorn-scrub. The ditches, blocked by vegetation and fallen trees, would cease to drain the flats, and these would revert to swampwoodland. The river, no longer controlled by the lock-system, would resume 
its ancient winter-flood habit, and tend to run out entirely in the summer months. In 100 or 200 years it is probable that the ruins of all the local buildings would be represented by grass-covered mounds and rubble-heaps, ${ }^{1}$ as are the sites of the earliest quarries at Headington. The suggestion of re-afforesting Bagley Wood with Larch and other alien conifers in close order implies the practical obliteration of the woodland as it has existed for at least many centuries. Yet the isolation of a tract of land at Cothill for purposes of Natural History, and the special study of the local fauna and flora, equally implies the production within a few ycars of an impenetrable undrained jungle of reeds and scrub, unless it can be intelligently 'preserved' from the standpoint of the organisms it is desired to perpetuate. The first law of all autotrophic life is growth, in response to certain conditions of the environment. If these last are changed, the responsc is altered or the plants dwindle and die out. The indigenous flora in the immediate vicinity of the town is in a state of rapid deterioration in response to the increasing difficulties of its struggle for existence; the utmost that can be done is to attempt to retain it as little altered as possible. How to 'improve' it in a botanical sense is beyond speculation, though foresters, agriculturalists, and gardeners may have their own special views on the subject.

From such general consideration of the condition of the earlier indigenous flora and the effect of human activities, as also of the introduction of new types of plant, largely replacing the old in some stations, sub-dominant in others, or still wholly sccondary and assisted, - it follows that many of the most characteristic features of the landscape and ecological formations may be the effect of compromise and mingling of these different factors. It is therefore convenient to consider them separately, as they give rise to communities of special biological interest, of which the component factors may not be obvious at first sight.

As such special cases may be distinguished :-

(I) Woodland and Copse.

(2) Underwood, Forest-plots, and Clearings.

(3) Hedgcrows and Hedgebanks.

(4) Regressive and Derelict IVoodland.

(5) Grassland and Pasture.

(6) Roadside and Waste.

(7) Crops and Weeds of Arable Land.

(8) Allotment-areas.

(9) River and Ditch Flora.

(I0) The Regression of Derelict and Cultivated Ground.

1 The finest mediaeval building in the district was Osney Abbey, with its accessory buildings rivalling any Oxford College of to-day. Built in 1129 , it was dismantled at the Reformation. Much of the stone-work, as also the big bell ("l'om', commemorating Thomas a Becket), were transferred to Christ Church. No trace now remains of this great building. The site was ploughed over in 1718 . 


\section{ARTIFICIAL PLANT-FORMATIONS Woodland and Copse.}

From a well-wooded district of original forest-formation ${ }^{1}$ the land has become progressively agricultural by reckless cutting down of the trees to promote pasture rather than tillage, very much in the manner continued by British colonists in the Eastern States of North America in the seventeenth century, and in New Zealand in the nineteenth. Huge trees were commonly felled and buried in trenches where too big for conversion or transport; ${ }^{2}$ but the necessity for fuel-supply always remained; the latter problem becoming the more intensified with the increase of urban population. Portions of residual woodland were left near farmsteads, and more so in the case of large estates, to be retained as coppice (copse) growth. Far-seeing colleges acquired their own tracts of woodland (Brasenose Wood, Magdalen Wood, Bagley Wood). Minor copses scattered very uniformly over the country afford the best examples of the state of the original woodland, with surviving types of undergrowth where the canopy was not allowed to become too dense. In the county as a whole, ${ }^{3} 86$ per cent. of the area is now brought under cultivation for crops or pasture, leaving about one-seventh as residual woodland. In the Oxford district of 30 square miles, little more than 3 square miles can be said to be forested to any extent." A rough distinction may be drawn between copse, as affording fuel and billet-wood, and woodland, growing high-forest for full-grown timber. No extensive tract of anything that can be called 'primary highforest' remains; the nearest approach to it being seen in planted woodland allowed to become more or less derelict as preserves for game (cf. parts of Wytham). Such districts, having been undisturbed for long periods of time, give a very full mixed undergrowth and ground-flora. The Royal Forest of Wychwood, Io miles NW., was the last considerable tract of woodland in the vicinity ( 3,735 acres); this being deforested, 1853 , with somewhat unsatisfactory results. The nearest extensive old woods are of poorest quality on the Oxford Clay at Stanton St. John, 5 miles NE. : Stow Wood, a fragment of a much wider area on Corallian, is now little more than a copse (30 acres). Bagley Wood, Wytham Great Wood, and Hen Wood, are left as isolated tracts of once continuous woodland, capping the hills; much of these districts being on land with little surface-water supply and no springs, hence useless for farmsteads. Nor can such ground be taken as really typical of what the best woodland would have been. The same applies to wooded steep slopes of ravines and gullies (Wick Copse, Hinksey Ravines).

All wooded tracts, continued under some sort of forestry practice, may be included as (I) Tall Coppice, (2) Underwood. ${ }^{5}$

1 In the sixteenth centary Camden $\left(1_{5} 86\right)$ records forests as the feature of Oxford scenery. Shotover was a forest in which Milton's grandfather was a ranger. Waste and moor stretched across Bullingdon to Magdalen Bridge. Much of the forest was cut down during the Civil Wars of the seventeenth century. In the eighteenth a mania for enclosure set in, and in the nineteenth everything left was enclosed on some pretext or another. The twentieth century sees, with minor exceptions, the general public deuied access to the residnal traces.

2 Plot (1705), Natural History of Oxfordshire, p. 165 .

Orr (1916), Agricalture in Oxfordshire, p. 193, Statistics.

1 Plot (1705), p. 52. 'The hills, 'tis true, before the late unhappy wars, were well enough bcset with woods, where now 'tis so scarce, that 'tis a common thing to sell it by weight, and not only at Oxford, but at many other places in the northern parts of the shire; where it is brought to Market, it is ordinarily sold for about one shilling the Hundred, but if remote from a great town, it may be had for sevenpence."

After another war (I921), rough wood sold at 25 s. a load, with 10s. for cartage from Bagley or ladley, retailed as wood blocks at 25 . per cwt., or Is. a bushel of $50 \mathrm{lb}$.

- Plot, l.c., p. 267 : sold 'to the meaner sort of people' by the Braid of 4 poles. 
In the former case, scarcely dignified as High Forest, large trees are grown in open canopy for timber and billet-wood, the undergrowth of minor trees being reduced or absent, as the last stage of residual standards or overwood. Trees were extracted as required, and regeneration apparently left to nature, as the last went. In such case a high light-canopy was long maintained, and the herbaceous ground-flora remained under very uniform conditions. Suggestive examples of tall-coppice are retained at Bagley (Middle Copse, Milestone Piece), Sidlings Copse (Wick), Marley Plantation (Wytham), and Stow Wood. The character of the undergrowth varies with the nature of the trees of high-forest: under Oak it becomes mainly Bracken and Brambles. Under Beech the ground is practically bare (Wytham).

Underwood expresses wooded areas growing minor trees, more definitely cropped in a rotation of 9-10 years or more; the old stools being allowed to regenerate, and the gaps made good by replanting. The trees are utilized for poles, hurdles, fuel, bean-sticks, and a large number of subsidiary purposes. ${ }^{I}$ This includes minor copses utilized for agricultural necessities, and large areas of residual woodland (Bagley Wood) are still in this condition. The state of the underwood varies according to the main crop, whether pure or mixed, and the nature of the soil. The growth of the herbaceous ground-flora also varies with the main-crop and the water-content of the soil, and is considerably affected by clear-felling and the first years of regeneration. Where the canopy is closely maintained and there is little water-content, the ground-flora may practically disappcar; this being the ideal of the forester.

Admirable examples of the difference in classes of underwood are afforded by tracts of Bagley Wood, of comparatively recent planting. ${ }^{2}$

(I) Sycamore coppice, giving clean-grown poles $(25 \mathrm{ft}$.). The summer canopy is particularly dense, and the undergrowth gives nothing but a fairly pure growth of Scilla mutans, flowering before the leaves are on the trees. (Felling commenced 1922 ; previously cut $\mathrm{r} 895$.)

(2) Alder coppice, at an optinum on the sides of damp gullies, giving clean pole-growth, 30-40 ft., very different from the stunted trees of river-margin and swamp-ditches. The undergrowth is mainly ferns (Pleris and Lastraea dilatata).

(3) Birch coppice, on gravel and drier soils, giving similar tall poles and light canopy ( $4 \circ \mathrm{ft}$.) ; the undergrowth being chiefly Bracken.

(4) Willow and Poplar coppice, on swampy bottoms of alluvium or clay, covering a damp undergrowth of Pteris, Nettles, and Mercurialis (Bottom Copse, Bagley; Headington Wick Copse). Cut also in 9 years rotation, cleaned and re-set.

Osier beds give a special case, at an optimum on irrigated land, and cut with annual cropping, in close-tufted growth which admits of little undergrowth. Local examples are very poor.

(5) Hazel coppice is widely distributed; the low trees with surface-root system doing well on clay where little else will grow; examples on Kimeridge

1 Woods (192I), The Rural Industries round Oxford, p. 79, Underwood Industries. Underwoods are sold or auctioncd to small dealers for cutting (leaving the standards) at so much the pole: cf. (192I) Nuneham Wood of good trees, cut at I 2 years, sold at is. 9d. per pole, giving fine poles to $20 \mathrm{ft}$. of Birch, Poplar, Maple, Chestnut, Oak and Hazel. Faggots find a ready sale at $6 d$. each. After paying for careful cutting, to avoid damaging the stools, and transport, there is little profit in the business. Radley Great Wood, of poor stag-headed Oaks with Ash and Sycamore over Hazel, sold at rod. per pole. Brasenose Wood of poorest Oak over thin coppice at $6 d$. per pole, $=£ 4$ per acre. Bagley Wood, old Oak coppice, cut I921, 1922, felched $£ 6$ per acre.

2 Bagley Wood was enclosed abont 1840 ; hedges were made delimiting the roads, tracts in the woodland cleared as ndes, and the whole rcorganized. These various coppices apparently represent. plantings on areas cleared at that time, together with many isolated patches of Larch, Spruce, Chestnut, etc., making good gaps in the general canopy. Later plantings of Larch, and Forest Plots $(190 \%)$, follow the lines of more modern sylviculture. 
Clay (Bagley Wood, Spring Copse, Bottom Copse), and on Oxford Clay (Noke Wood). Cut in 9 years rotation it gives remarkably clean straight basal shoots as poles and slender rods. It was formerly much in demand for wattle hurdles, etc. When neglected it fills up with Rose Briars and Brambles; the stems becoming irregular and forked are only good for faggots. The summer canopy is dense, and the ground flora is restricted to spring-flowering Anemone, Scilla, Ficaria, Mercurialis, etc., often very beautiful.

(6) Oak coppice, yielding durable poles and fuel, is the most characteristic type and general case. Cut normally on a ro-year rotation, but now often much neglected and running to waste at 20 years, owing to reduced demand or expense of conversion. ${ }^{2}$ Large tracts of Bagley Wood remain in this condition, with little change since mediaeval times. ${ }^{2}$ The stools are left knee-high, and regenerate a close tuft of laterals, several of which may make good poles; the stools being spaced at a distance of $3 \mathrm{yds}$. apart. Where the growth is uniform and vigorous, a dense canopy will be maintained; and, where dry, little undergrowth of any sort is left, the ground being covered with persistent dead leaves. But on clearing, a rich undergrowth of herbaceous types is met with in the first few years of regeneration. It is open to invasion by berry-bearing forms (Rosa, Rubus, Viburnum Lantana), and commonly shows admixture of other trees, cut at the same time and similarly regenerating from stools (Ash, Willow, Hazel): cf. Kennington Clearings (1920-22), Underwoods.

The most general type of older cultivation is included as Coppice with Standards, as an attempt at the combination of the two preceding cases, which may also be regarded as limiting stages (early and late) in this type of growth. A few trees may be left to grow on when the main underwood is cleared, just as a few trees are often similarly left when hedges are trimmed; and these are allowed to persist over several fellings. The method follows a natural process of evolution, and has been convenient in the past, as the demand for underwood material and fuel was thus proportioned to the smaller requirements of a distinctly agricultural community. From the standpoint of the latter it has many advantages in utilizing waste land; but otherwise the method is uneconomical. An isolated standard tree completely destroys the regeneration of the underwood over a light-area marked by its canopy, and the active regeneration of the underwood beyond this area checks the water-supply of the standard. The canopy of the whole coppice becomes discontinuous, so that both types of tree are injured. Thus, where standard Oaks are left in Oak-coppice, the former become stag-headed at the level of the underwood-canopy, with short bole (I 5-20 ft.); light is admitted under the loosely spreading branches sufficient to supply a colony of Bracken beneath the standard. The same effect is observed when standard oak is left in Sycamore-coppice, and the injurious effect on the crop is still more marked when residual oaks are left among Larch and Scots Pine.

Remarkable examples of this class of coppice are left at Bagley, where old stools of indefinite antiquity, moss-covered and moribund, give underwood in stunted growth, $10-12 \mathrm{ft}$. high only in 20 years. ${ }^{3}$ Interesting cases of regenerated 'standard' Birch among Larch and Weymouth Pine give trunks 12 in. diam. and several $\left(5^{-6}\right)$ from one stool.

Where well-grown, coppice underwood of Oak, close-planted areas of Larch and other conifers, or coppice under standards, gives no herbaceous ground-flora at all. The residual tall-coppice, however neglected from the standpoint of the forester, affords with its scanty canopy, the best collection

1 Woods (I921), loc. cit., p. 83, foot-note.

2 Plot $(1705)$, p. 267 , gives $7-8$ years rotation; also 20 years for Wychwood Forest.

3 This ancient stool-coppice was probably planted in the seventeenth century, when fuel became scanty. Otherwise there is nothing in the wood over 200 years old. 
of plants of the underwood botanically; and in virtue of its very neglect sylviculturally, is most suggestive of the original condition of the indigenous woodland, when the trees of high-forest had acquired full dominance.

From the point of view of the sylviculturalist, the dense herbaceous undergrowth is not only useless, but is to be regarded as a growth of noxious weeds, as are the weeds of arable land to the farmer or allotment-holder. To grow trees alone, the entire area should be cleared of Brambles, Bracken, and all herbaceous forms, and underplanted with Beech, to leave a floor-covering only of dead leaves and humus; in which case the indigenous flora would vanish, or be left only as vestigia in hedges, ditches, and rides. Much of this type of woodland at the present time has gone too far to be worth saving, and is valued chiefly as a covert for pheasants.

Oak-coppice on good ground is supposed to last for ever; on poor ground it begins to fall off after 100-I50 years. The old moss-covered stools at Bagley, in the last stages, some merest shells, may be $200-300$ years old, giving regeneration-shoots in irregular dwarfed growths, which are but a caricature of an oak-tree.

The custom of clearing underwood, and 'drawing' tall-coppice and standards, which has been going on for at least 500 years, with no return whatever to the soil, must have had an appreciable effect on the mineral and especially phosphate-content. If pastures which have been long grazed are now found to require superphosphate and basic slag, the same should apply with greater force to the neglected woodlands, the food-supplies of which have been apparently assumed to be inexhaustible. Stag-headed Oaks are devastated by the Tortrix Moth, and regenerating underwood badly mildewed. It remains to be seen to what extent matters can be improved by clear-felling the older wood and replanting with Larch and Douglas Fir or other Conifers.

Following the importation of coal by barge (the Birmingham-Oxford canal completed in I790, and still used for the purpose), the importance of copses as fuel-supply was much diminished, or such material was left to people beyond the urban area. Present examples are hence much reduced and neglected, or are only utilized for purposes of game and investigated for rabbits. The ground-flora fills up with small underwood, often becoming almost impenetrable, with thorns, sloe, brambles and briars. Especially on dry soils this degenerates to a condition which cannot be distinguished from regressive thorn-sciub (Bagley, upper West Wood, Hutchcomb Copse).

In damp areas, as on the alluvial flats, Willows (Salix alba, S. fragilis) were similarly utilized and planted as sets (Ioft.) along the sides of streams and ditches. When pollarded, these assume a mop-headed brush-effect which gives a characteristic appearance to the flood-level landscape, and affords a case of special biological interest.

No special rule is observed in pollarding. Shoots may be cut at 2 years for bean-sticks, as growth in the first year may be $6 \mathrm{ft}$. Larger poles 20-30 ft. are obtained in ro years. Neglected trees may be pollarded and then left to grow out indefinitely ('Mesopotamia').

All pollarded willows become subject to attacks of Fungi, and are ultimately destroyed. After pollarding, strong new shoots send down roots of their own, descending under the bark of the old trunk to the soil. The original trunk, always decayed by Polyporus attack, infecting from the wounds, ultimately becomes a mere hollow shell, and the functional head of the tree stands on pillar-roots which are only revealed by tapping or slitting the bark. In a further stage the old shell splits with the increase of new 'stems', falling asunder in 2-3-6 'split Willows', each supported on its own divergent trunk, or falling over if not strong enough. A willow can be so pollarded half a dozen times before badly decaying: they become hollow shells in 50 years. 
The bushy growth of green shoots after pollarding, and the collection of wind-borne débris between the old stumps and decaying twigs, affords a nidus for all sorts of seedlings to germinate, often with conspicuous success, as a flora of humanly assisted epiphytes. Minor plants as Taraxacum, Aquilegia ( $3 \mathrm{ft}$, and 60 flowers), Senecio squalidus, thus flower and fruit on the heads of the trees, with roots sunk deep in the decaying central mass. 'Epiphytic' brambles and briars may send their roots down to the soil inside the trunk, and hang as lianas from the upper branches. Woody forms follow the same course, and well-grown bushes may be found in Willow heads (Ribes, Elder, Viburnum). The limiting case of a Pyrus Aucuparia, $20 \mathrm{ft}$., was noted near the Botanic Gardens; but these are cut away in the pollarding rotation, and their further development is checked. ${ }^{\text {I }}$

Forest Plots and Clearings. In all cases of clearing and felling, or of coppicing and planting, the effect of human agency is directly obvious, and the ecological interest centres in the recovery of the ground-vegetation, as much as in the regeneration of the woodland main crop. Beyond the general exploitation of the woodland included as Forestry, Sylviculture is concerned more particularly with the regeneration of the woodland and the growth of some special form of tree. As in the case of agriculture, this involves a weed-problem, as other plants require to be kept in a subsidiary position, or preferably wholly eliminated. On the other hand, the ordinary agricultural methods of ploughing, cultivating, manuring, and sowing, involving considerable labour and expense, when operations are conducted on a still larger scale, are commonly ruled out. Regeneration is thus left to natural causes, or forest-land has to be planted.

Older methods of forestry as cultivation of coppice with standards, or their limiting cases, ${ }^{2}$ in past centuries, express the retention of a practice introduced from the continent, and still largely followed in France, which aims at the supply of the needs of a countryside with a cheap sonrce of fuel, as well as agricultural timber and poles. For these purposes the underwood is cut in rotation of 8-10 years or I $^{-20}$ years, often before the trees flower and fruit. As such coppice is not everlasting, although oak-coppice endures a long time, for purposes of regeneration a few standards are left at intervals to supply the necessary seed. In such case regeneration is left to nature, the underwood is cut with one rotation, e. g. Io years, and the standards are given a rotation of possibly roo years. ${ }^{3}$ The application of the system, however otherwise objectionable, is seen in the fact that natural regeneration is provided for from the first; and in the case of an indigenous tree, a dense crop of seedlings will keep down intrusive weeds as herbaceous ground-flora and grasses.

More modern forest-practice may differ in that :-

(I) The tree favoured as main crop may not be an indigenous form at all, but one giving a greater or quicker return of timber, or one which is cheaper in production and conversion, as also commanding a better market.

(2) The woodland may not be grown for local needs at all, particularly in a country where there are other sources of fuel, and the crop may be so far a commodity for export.

Both cases are admirably illustrated by the general cultivation of Larch poles for mine-work (pit-props).

In such case the regeneration cannot be left to natural causes; that is to say the forest requires to be planted; while, as the trees when young are less likely to compete successfully with the indigenous flora, the 'weed'-problem

1 Plot (1705), p. 173, records the case of an Ash which grew until the Willow shell was left as a relic : a good Elder tree ( $15 \mathrm{ft}$.) on a Willow at Wolvercote, 1922.

For a list of 60 species of plants noted on Willows at Oxford, ef. Gunther (1912), Oxford Gardens, p. 259. Other trees are less frequently pollarded, but an Elder ( $5 \mathrm{ft}$.) grows on a Sycamore which has been formerly pollarded, at Godstow.

2 Schlich (1910), Manual of Forestry, Silviculture, ii, p. 106.

Schlich, loc. cit., p. 105. 
arises; and the plots require a certain amount of attention in early stages. Hence in the cultivation of such a form, seedlings have to be raised in a nursery, planted out in an early stage of growth, and the rapidly growing weeds and intrusives kept down by methods of cleaning.

In general practice young plants from the nursery are planted at $4 \mathrm{ft}$. apart each way, to grow to uniform pole-height, before thickening the main trunk; and by making close-canopy these may effectually dominate the groundflora in the course of a few years. Full dominance is only gained in 1o years or so. In the first years after planting, the ground-flora may be more conspicuous than the crop; the spaces regenerating Bracken, Brambles, and a large supply of intrusive grasses, unless these are periodically cleaned and cut out. All such cleaning and early thinnings add to the expense of production; and the age of the crop for felling, simultaneously as a crop, has to be adjusted by financial considerations in order to make it pay. A continuous output is maintained by a succession of plantings, involving successively maturing tracts of such woodland.

As local examples of such methods may be distinguished:-

(I) Clearing of Oak coppice, ${ }^{1}$ allowing free light-supply to the ground-flora, but with effects of increased desiccation owing to the loss of the damp canopy. Xeromorphic forms become more conspicuous, with a wide range of intrusives from dry situations, giving a greatly increased variety of species (60-100); Kennington underwoods, Oak-stools at 3 jards apart.

With the growth of the coppice-regeneration after $4-5$ years, these in turn dwindle, shade-plants become more numerous, and in 8-9 years the effect of a shaded woodland, largely restricted to spring flowers, is again produced.

(2) Clearings of more modern forest-practice, involving clear-felling of older woodland, and replanting with a crop of deciduous Larch, either pure or subsequently underplanted with Abies or Beech; the trees being planted at $4 \mathrm{ft}$. From the examination of plots of different ages, it is possible to visualize at one time the successive stages of succession; and the general effect as the control of the ground-flora expresses the success of the working-plan. (Sunningwell Bottom, Milestone Piece, Bagley Wood.)

Good examples are afforded by the experimental plots of the Forestry School at Bagley Wood. Such plots are however subject to periodic cleaning, with removal of the larger intrusive shrubs, bracken and brambles, as also the thinning of the main crop and removal of dead laterals.

Cases of special interest, followed in such forest-plots, are observed as the main crop involves a tree-form which may be evergreen, or distinctly alien, or no longer indigenous, and its relation to the general ground-flora. Such plots include Pinus sylvestris, Pinus Strobus, $P$. Laricio, under which, when planted at $4 \mathrm{ft}$., the canopy is so dense, and the ground so covered with a carpet of needles (2-3 in. deep), that nothing whatever grows, as soon as the canopy is attained. The same applies to Pseudotsuga and Thuya plicata with still darker canopy: in the last case, with deepest shade, the floor is a dense carpet of dead phyllomorphs, through which not even a residual Scilla pierces. Pinus-canopy opens out after 20-25 years.

Under Larch, however (European, Siberian, Japanese), owing to lighter canopy in summer, and the deciduous habit, the undergrowth at first may fill up with Bracken, which when left uncut, ${ }^{2}$ is the agent more particularly concerned in keeping down all lower ground-flora. Brambles may long continue; but the carpet of needles is at length only varied by a few stray plants of Ajuga, Teucrium, Scilla, etc. (20 years). On thinning, and growth to higher canopy, at 30 years Larch-plantations may again give Bracken undergrowth as light penetrates, and should be under-planted. ${ }^{3}$ The crop matures at 60 years or more.

1 Schlich, loc. cit., p. 341.

2 Owing to want of labour during the years of the war, many of these tracts were much neglected, and are not io be taken as fair samples of sylvicultural treatment.

Schlich, loc. cit., p. fo.t. 
Hedgerows and Hedgebanks. The use of some sort of barrier, whether wall, hedge, or ditch, delimiting property, as land isolated for some special purpose, or for preventing cattle from straying, would appear to be a natural commonplace of human occupation. Walls and hedges may play a subsidiary part in a local flora, the more conspicuous as the plants are usually elevated to a position in which they attract the eye; and these formations afford a wide range of secondary biological stations of particular interest.

(1) The masonry wall of squared cut stone (ashlar), or of rough rag-stone from the Limestones of local Corallian or Portland beds, soon affords a nidus for intrusive rock-plants, germinating in cracks of the stonework, following mosses and lichens which obtain water from the damp stone, the more conscrved internally as the outer surface may be impervious, and channels follow the lines of rain-drip. Walls built of the eminently soft, porous, and rapidly weathered free-stone from the older Headington quarries, soon develop a flora of a few grasses and larger flowering plants, of which the most conspicuous are

Senecio squalidus, ${ }^{1}$

Hieracium murale,

(Dianthus caesius), ${ }^{3}$

Snapdragon and Wallfower.

Only very exceptionally in this district do old stone-walls carry small ferns :-
Polypodium vulgare,
Asplenium Ruta-muraria,
Cetarach officinarum,
Asplenium Adiantum-nigrum.

(2) Rough rag-stone walls of farmsteads, gardens, etc., with or without mortar, acquire a moss-layer, soon giving a coating of fine soil, which may carry a miniature crop of Draba verna in early spring, followed by a special flora of diminutive forms (Iffley, Hinksey, Horspath, Headington); cf. :-

Senecio vulgaris, one inch high, reduced to one terminal capitulum.

raleriana olitoria, $\frac{1}{2}$ inch.

Arenaria serpyllifolia, Io $\mathrm{mm}$. high, reduced to one terminal flower: also-

Linaria Cymbalaria,

Crepis taraxacifolia,

Poa annua,

Sclerochloa rigida.

These tend to wholly disappcar as summer heat shrivels them; and only specialized xerophytes retain their stations :-

Sedum acre,

Sedum refiexum,

Saxifraga tridactylites,

Sedum dasyphyllum,

with starved forms of grasses as-

Festuca bromoides,

Poa compressa,

Hordeum murimum, Bronus sterilis;

and more casually, Corydalis Lutea, Linaria purpurea, Centranthus ruber, Verbascum Thapsus, with more definitely alien Cheiranthus, Antirrhimum, and obvious garden-escapes as Arabis alpina, Arenaria, Alyssum, and planted Sempervivum tectornm.

(3) The case of the rough stone wall grades naturally into that of the hedgebank built more or less of a mixture of stones and earth, as a station with considerable possibilities from light-exposure; but subject to reduced water-supply as the summer advances,-ultimately becoming wholly dry from above. On such hedges the spring vegetation may be abundant; but later in the season they show little more than the usual associates of waste-places and rubbish heaps, with no special characteristics of their own.

1 Hence commonly known as the 'Oxford Groundsel', the bright yellow flowers of which have been seen on the Examination Schools (erected I882), on the Radcliffe Camera and many old bnildings and College walls : on the Town Hall (built 1897) immediately following clumps of moss.

2 Un old walls, Lincoln College, Blue Boar Lane, often very conspicuons.

3 Residual on wall of Wadham College, and St. Hilda's (once Sibthorp's residence). 
(4) The true Hedgerow, as generally understood, is a more complex construction, as an earth bank separating fields, etc.; the material used to build the wall being taken from the ground level, and leaving a ditchdepression at its foot, which subserves drainage; while arborescent forms are planted as shrubs or small trees on the top to increase the obstruction to cattle or human beings. Such a hedge is required to be strong enough to keep a bullock from thrusting through, or a horse from jumping over.

The characteristic hedge is built from sets or seedlings of spinous Hawthorn (Crataegus monogyna). Trees may be subsequently encouraged in such a hedge, as affording casual shade for cattle, and for utilization as rough timber; these being left to grow on as standards, when the thorns are periodically trimmed. The leaves shed from the deciduous shrubs accumulate in the hedge-bottom, as a humus-soil which nay be of no great thickness, but serves as a nidus for a large collection of woodland plants, together with many intrusives from waste places.

The hedge is in fact a miniature edition of woodland, but regressive and artificial rather than vestigial. The upper part may epitomize standards with coppice, as the wet ditch may recall swamp-woodland, or the grass and herbage of the sides a mixed pasture. The wooded portion has been commonly so treated by the agriculturalist, with suggestions of an underwood rotation and the felling of standard trees; while the herbage may be cut in the manner of hay for fodder and bedding. It is, in fact, this character of presenting a sample of all types of country vegetation which makes these structures so characteristic of English scenery, and so interesting botanically. In the course of years, such hedgebanks attain a considerable size, and take up a considerable proportion of the land under cultivation. The standard trces, for example, may affect planted crops injuriously for a distance much farther in than that of their leafy canopy (to $50 \mathrm{ft}$.). Hedges may considerably add to the aesthetic aspect of the landscape, but economically they are unsound, and often a nuisance. On the whole they are to be regarded as the survival of a past epoch.

The formation of hedgerows is of comparatively modern growth. In mediaeval England, beyond fences and walls around gardens and orchards, there were practically no hedges. Under the feudal manorial system of land-occupation, the greater part of arable land was worked in common under the Lord of the Nlanor, only fenced in when the crops were standing. Beyond the more cultivated tracts was open common land, including waste and woodland, where this last was not a part of a Royal forest preserved for game.

Hedges delimiting smaller tracts of land came in with the decay of the feudal system, and after the Wars of the Roses, with more particularly an increased output of cattle and the beginning of an improved agriculture. Such enclosures of arable land, thus manured for growing corn, as field-units specialized for different agricultural work, increasing from the sixteenth to the eighteenth centuries, encouraged the small-holder, and led to the system of farming which has continued to the present day. It must not be confused with the enclosure of open common grazing-ground and waste-land for cattle and sheep-runs, which was a fruitful source of rioting on the part of dispossessed peasantry from the fourteenth century to the present time.

It would appear that hedges were constructed primarily with a view to the needs of stock-raising; and their persistence and prevalence indicate a district given over to cattle-rearing rather than to cultivation of cereals. From such a standpoint the advantages of hedges are obvious, as they are numerous (Fitzherbert, I523, Book of Husbandry, and The Book of Surveying). They may be regarded as a more permanent extension of the method of folding sheep with hurdles. Cattle.herds were dispensed with; small tracts of land could be grazed and intensively manured without damaging and trampling the whole. 
The available food-supply was thus brought under control, grazing cattle were given shade and protection from storm and cold, while the small farmer was no longer penalized to the advantage of the larger owner on the common land. The tree-material, again, furnished a local supply of small fuel, near at home, and compensated the disappearing woodland.

On the other hand, hedges entail considerable skilled work in construction and maintenance. The original use of a thorn-fence of 'quicksetts', implied cutting, trimming, and interlacing to a typical fence of $4 \mathrm{ft}$. in height (impenetrable by cattle), which has had much to do with the evolution of steeplechasing and hunting in central England. ${ }^{1}$

Even a thorn-fence requires careful attention. Though the Hawthorn is the most enduring tree of the countryside, it cannot be cut indefinitely. When pruned to a neat and constant form by 'removing the spray' of annual shoots, the plants will deteriorate in time. Hence they soon require to be left to grow out for a season or two to recover vigour. If this happens to be neglected, the plants grow to bushes, with admixture of intrusives which may soon become dominants. Deteriorating still further, the thorns are cut back to stumps, with a rough rotation of Io years or so; the hacked and split stools make an indifferent recovery, and the majority of hedges of this class are now mere wrecks, or in any case, something quite different from what they were originally intended to be. ${ }^{2}$

As pasture-land thus devoted to stock again becomes utilized as arable, hedges tend to disappear, being valueless except as wind-breaks in exposed situations, and the fields may be delimited by wire fences. But the more recent application of barbed wire is the limit. ${ }^{3}$

When allowed to vegetate quite freely, the thorns attain a height of 20-2.5 ft., affording a canopy as many feet wide. A rank growth follows in the drip of the end-branches, which then becomes the limit of the field-area, whether pasture or arable. Coarse grasses, nettles, brambles, and briars grow up to meet the canopy of the thorn, giving a continuous mass of foliage as a screen to the ground-level; and this as the hedge-base affords a station for a wide range of herbaceous forms, graded according to their height and the distance to free light-supply. Hook-climbers and tendril-climbers interweave in the mass, or clothe the upper levels. Within the more shaded central tract, vegetation is checked and may wholly disappear, giving a tunnel-effect, with the original thorn-trunks in the middle line, as a run for dogs and small boys. Gaps in the outer canopy of brambles and thicket allow cattle to utilize the tunnel-portion for shade and shelter. Large trees allowed to persist as standards, especially the Common Elm, as intrusives, less frequently Oaks stag-headed at the brushwood level, afford a dense canopy, ultimately suppressing the thorns, and leaving gaps in the fence.

1 The neat professional thom hedge, trimmed $4 \mathrm{ft}$. high, and interlaced obliquely (plashed), affords little scope for intermixture with intrusives until it is badly neglected, and allowed to grow out. A county instructor in hedging is now employed by the County Council.

2 The most interesting trimmed hedge locally is the remains of the ancient thorn fences bonnding the path raised above flood-level between Wytham and Godstow. Donble hedges of thorns planted $\mathbf{5} \mathrm{ft}$. apart, and more or less neglected, give a peculiar tunnel-like conslruction in meadows above Wolvercote. Thorn fences of Bagley Wood dale to about $184^{\circ}$, those bounding the Railway Line to abont 1850 . Such hedges, once carefully kept, are seen in all stages of neglect and decay in the fields absorbed within the urban area (Cowley), redncing to a single line of residnal standard thorns $(25 \mathrm{ft}$.), these then more and more isolated, or left as stumps against which cattle rub.

3 Barbed Wire, a product of the evolntion of the Western cattle ranches of America, has been manufactured since 1874 . The initial cost is comparatively small, and it is practically indestructible if the supports are also of steel or of reinforced concrete. Cattle avoid it, and it solves the weedproblem of the hedges. It is also almost invisible in the landscape, but it affords no shelter from wind or sun. Legal restrictions so far (1893) apply only to the possibility of damage to persons or cattle lawfully using the highways. But the country walk of the future tends to be restricted to a straight and narrow gangway between two lines of barbed wire (cf. path from Headington to Shotover Hill). A gracefut finish is given by tacking a strand over the top of any gate at which one might wish to stop to admire what is left of the view. 
As nothing lives long in the shade of a big tree, a gap can be always located near a tree trunk; such gaps require constant mending, and are commonly made good with a generous use of barbed wire. ${ }^{1}$

Such hedgerows with great range of biological factors, free insolation, good drainage, and damp bottom, carry a correspondingly wide range of types, which defy analysis, until it is realized that the assemblage is purely artificial, and that all the forms are competing according to their special requirements and capacity for getting there. At their optimum these hedges present all the phases and features of regressive woodland, the initial thorn-fence is as often lost to sight, as it is only traced in historical development. The larger trees of high-forest afford shelter and humus for woodland undergrowth; grasses and herbaceous plants of the pastures cxtend to the lower levels. Tangled lianas add to the jungle-effect, and subaquatics may flourish in the ditch. Forms with deep-running rhizomes and roots send up aerial shoots extending along the length of the mass. The flora of such hedgerows constitutes a special fcature of any agricultural district, and locally may include over Ioo forms taking part in the annual succession.

From forest-trees (Oak, Ash, Willow, and particularly Ulmus campestris, running its soboles along the hedge-line), to minor woodland forms, Hazel, Sallow, and woody shrubs growing from berries brought by roosting birds (Viburmum Lantana, Cornus, Ligustrum, Rhammus catharlicus, Prunus spinosa, Pyrus Malus, and especially Sambucus) to scrambling forms as Rosa, Rubus in variety. Climbers include Solanum Dulcamara, Calystegia, Lonicera, Humulus, Bryonia and Tamus, to Galium Aparine, Vicia Cracca and Galium Mollugo. Larger grasses push through, as Dactylis, Arrhenatherum, Bromus asper, Brachypodium sylaticum, Agropyrum repens. Herbaceous forms follow the annual succession-Alliaria, Anthriscus sylvestris, Lychnis dioica, Geranium robertianum, Stachys sylvatica, etc., to more xerophytic summer flora of Heracleum, Pasinaca, Dauius, Carduus (sp.), Rumex (sp.), Senecio Jacobaea, and Helminthia echioïdes. Special cases of deep-travelling rhizomes give hedgebanks in damper situations dominated by Spiraea Vlmaria, Epilobium hirsutum, Equisetum Telmateia, Phalaris arundinacea, and Phragmiles communis.

Examples of such formation afford interesting studies for more detailed ccological examination, as each station requires to be taken as an independent complex with special factors of soil and water-supply of its own; as also of the nature of the surrounding associations which supply the initial equipment.

(5) The casc of the Hedgebank, as a deep road-cutting, where the roadgradient has been lowcred, is less general in a flat country. It differs from the preceding by being backed against solid ground with assured watersupply. Such banks carry a more abundant flora; and where shaded may retain the characters of damp woodland, with characteristic woodland forms (Primrose, Violet, Melica mutans, Malva moschata). (As a minor cxample, cf. Kennington Lane, 'Little London', until recent times a woodland track.)

Such banks grade into the case of the railway-cutting, wherc this is deep and wide enough to be left to something bcyond mere grass (Littlemore, Horspath). On Corallian strata these carry an abundant flora, and

1 Barbed wire entanglements fill gaps so cheaply, that good hedging tends to vanish; but the wire when rusted and concealed in later growth, is dangerous as well as objectionable. Though the use of barbed wire tends to increase nearer the town, the condition of the hedgerows affords a good test of the quality of local husbandry. In the more open country, the neat thorn-fence is dominant, and often remarkably so. Where deteriorated and ruined, the original thom-stumps can be generally traced among the overgrowth; substitution of Prusues spinosa in exposed areas, or Myrobolan Plum around garden-tracts, gives no better results. The most destructive intrusives are Elder, Hazel, and Common Elm; the two last run lengthways in the fence, and may in time wholly dominate it. Minor garden-hedges of Privet (Ligusirum japonicum), Yew, Beech, Cupressus Lawsoniana, Holly, attain a decorative value as they are kept constantly clipped and clean. 
may tend to regress to woodland shrubs; but they are subject to destruction and intentional clearing by fire.

The case of the embankment is more artificial, since the material is largely gravel-ballast, well-drained and exposed to considerable desiccation in summer. The vegetation is usually particularly luxuriant and advanced in early summer; but is also subject to cutting and intentional or accidental destruction by firing in the dry season, with consequent wholesale renewal.

(6) As a converse case, the hedge and ditch in the alluvial area tends to be replaced by a ditch only, and the latter subserves drainage as well as acting as a barrier to cattle if deep and wide enough (6-1o ft.). The material taken from the ditch is used to increase the height of the sill. Such ditches are then connected in an irrigation system, linked up with the larger streams, and not only take away flood-water, but will retain standing water over long periods of drought. They hence become sccondary stations for abundant aquatic types, enriched by surface-drainage from the pastures with animal-droppings, and again give a wide range of flowering plants, as a special meadow-ditch flora of about 100 forms (cf. Iffley Fields, Marston Meadows, Hinksey, Botley), quite distinct from those of the adjacent pastures, though subject to a certain amount of overlapping, as typical ditchplants may be intrusive in the damp pasture and arable land (Phragmites, Equisetum, Polygonum amphibium); while the pasture-weeds may encroach on the ditch margin (Carduus arvensis, Rumex crispus). Characteristic plantsare Spiraea Ulmaria, Epilobium hirsutum, Valeriana (sp.), Mcntha (sp.), Enanthe fistulosa, Nasturtium amphibium, Myosotis palustris, and in or by deeper water, Scirpus lacustris, Sparganium, Sagittaria, Butomus, Sium latifolium, Alisma Plantago, Rumex Hydrolapathum, with numerous large Carices (C. riparia, C. paludosa, C. vulpina); also Hottonia, Hydrocharis, Lemna and Myriophyllum in the water.

All these types of Hedge-formation acquire special interest from observation of the relation of the annual succession to their water-supply, which remains the local limiting factor, since temperature and light may be taken as fairly uniform: as also from the standpoint of succession in time, as the particular formation is initiated, and in the course of several seasons attains its special character. It must be noted that the constancy is largely maintained only by human agency, and that all are subject to the possibility of human interference and destruction at any time; as hedges may be trimmed or wholly demolished, and ditches may be cleared out, drained off, or filled up again. The common type of mixed hedgerow is subject to a rotation of a definite number of years (averaging Io), to prevent too great invasion or shading of the field-area, or to supply brushwood for fuel. Hedging and ditching becomes skilled agricultural labour, and is too often a lost art. The inferior types of hedge, as indicative of a deteriorated condition of husbandry, are the stations most let alone; the examination and observation of the biological factors of a 'hedge', and the phenomena of its annual succession, progression, or retrogression, afford good exercise in floristic and ecological instruction, and further examples may be taken in detail.

\section{Regressive Woodland.}

Woodland areas, cleared of all standing timber, and regeneration prevented, as by paring and burning, become an open clearing in which the original humus-flora of the woodland-base soon deteriorates, and may be completely destroyed on exposure to the desiccation of summer sun; the more quickly on clay tracts in which the soil may be badly cracked. With the addition of intrusive weeds of dry pastures, the soil soon reverts wholly 


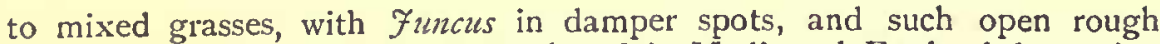
grazing land was particularly developed in Mediaeval England, becoming the general formation of waste common land; controlled by keeping down all attempts at woodland regeneration, giving material for faggots and fuel, or intrusive Bracken and Furze kept down by firing, and so maintained indefinitely, so long as grazing for horses and cattle was the dominant factor.

On enclosure, or neglect of the original use, such land rapidly changes its appearance; the larger perennial xerophytic forms, enduring the summer heat, become predominant, and spring-vegetation of perennial habit may grow above the grass-level especially favoured by rabbits and cattle. Thorns, Brambles, and Roses take root: on lighter soils Ononis spinosa and Thistles; on heavy soils especially Crataegus, Rosa canina, and $R$. arvensis, to be followed by Rubi, Lonicera, Prumus spinosa, Ulex and Pteris. Where cattle continue to graze, such spinous plants become centres of dense bushformation; Brambles and Roses rise over the Furze-bushes ; cattle grazing on the residual herbage work out grassy tracks between and around the bushy growths, and the whole becomes a regressive rose-thorn scrub, which will further grow on to an impenetrable thorn-thicket, dominated by Crataegus and Prmes spinosa as these in turn rise above the level of the roses and

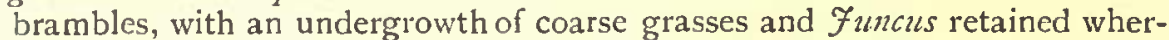
ever light can penetrate. On these trees lianoid forms as Bryonia, Calystegia, Solanum Dulcamara, and Loniccra give massed growths, the last flowering freely at the top of the scrub (20 ft.).

Among such thorn-scrub other trees may germinate and grow under the damp cover, especially Acer campestris, Salix, Alnus, Fraxinus and Oak. As these forms will all grow on above the thorn-zone, and the Oak is the most enduring of all, the last stage gives poor oak-trees, stag-headed above the level of the underwood : the latter, shaded out, is gradually replaced as the canopy becomes dense, and Hazel may come in with increasing humus in the damp bottom, with Elder in the dampest spots; giving in time an Oak-Hazel coppicc, mixed with minor trecs, which may be cultivated on the coppice-under-standard principle, as the underwood is cut out, and a few of the more likely-looking trees (Ash and Oak) left to continue at successive clcarings. In thinning it is evident that the generally established older forestry practice, dignified by modern writers as 'Coppice with Standard ', expresses the natural evolution of the countryside, satisfying the requirements of peasant-proprietors, without any special forethought or calculation; however subject to further elaboration as the clearing periods become more systematized. ${ }^{2}$ A woodland which has been coppiced or drawn for several centuries is by no means virgin forest. Much of local woodland is astonishingly poor in tree-growth, suggesting that the soil is wholly exhausted, having been thus cut for many generations with no return whatever, or too recklessly exploited.

Good examples of this progression are still afforded by parts of 'Open' Brasenose and 'Open' Magdalen, grading to the later phases in Magdalen Wood and Brasenose Wood, of poorest coppice on Kimeridge Clay. Much of the older and more neglected part of Bagley Wood (Spring Copse) is little better; and this seems to be the general mode of origin of many small Copses, which are probably not so much the retention of areas of primitive woodland, as secondary regressions of partially cleared 'waste'. Older woods are really as artificial as the compartments of modern forestry practice; only the muchenduring ground-flora has any claim to be in direct succession. The last phase

I Schlich (I 910$)$, Manual of Forestry, ii, Silviculture, p. I04.

2 Schlich, loc. cit., p. r05; age-gradations being more generally attended to on the continent. 


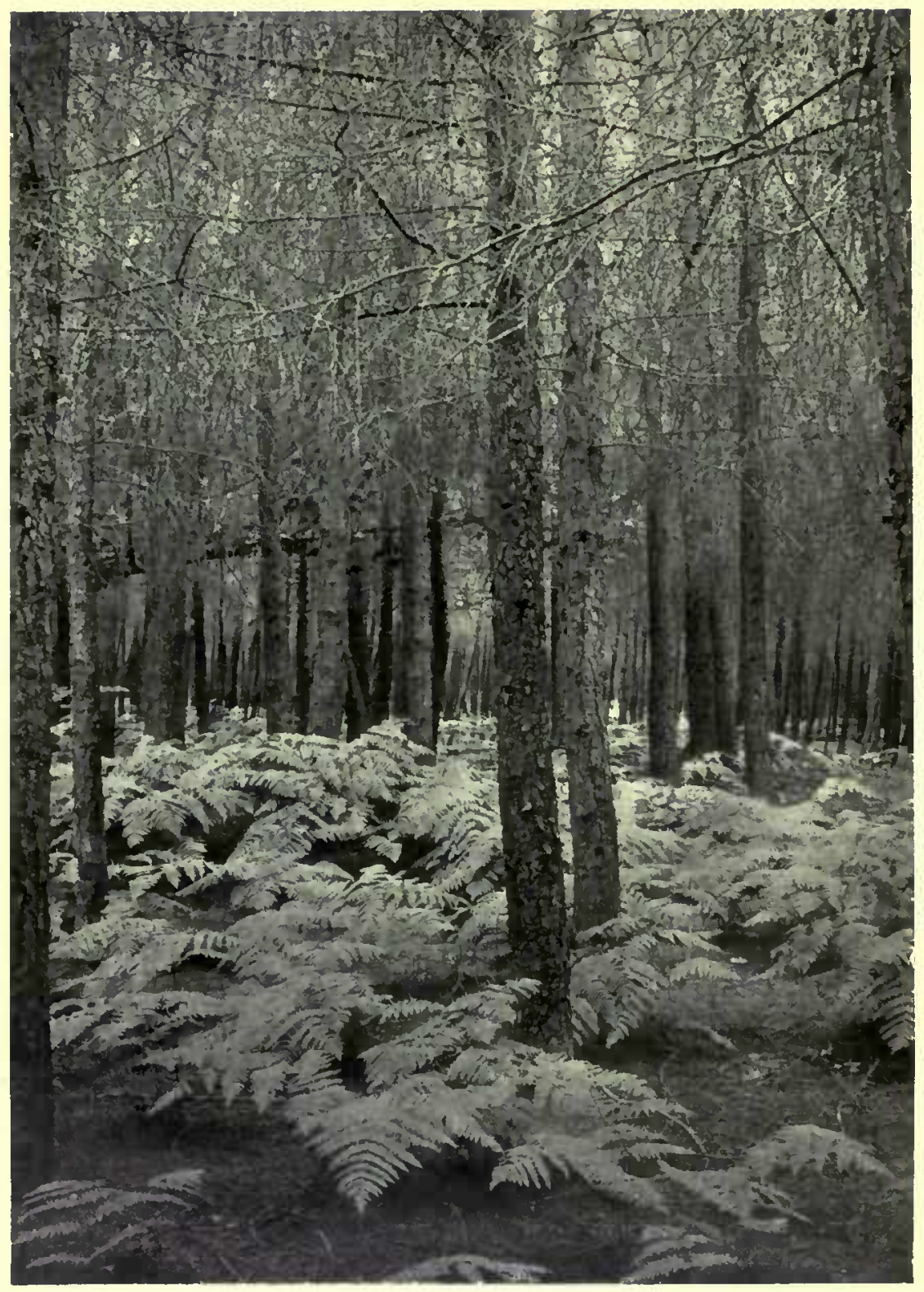

8. Bagley Wood, Aug. I922. Larch-plot with Pteris invading bottom at 25 years. 


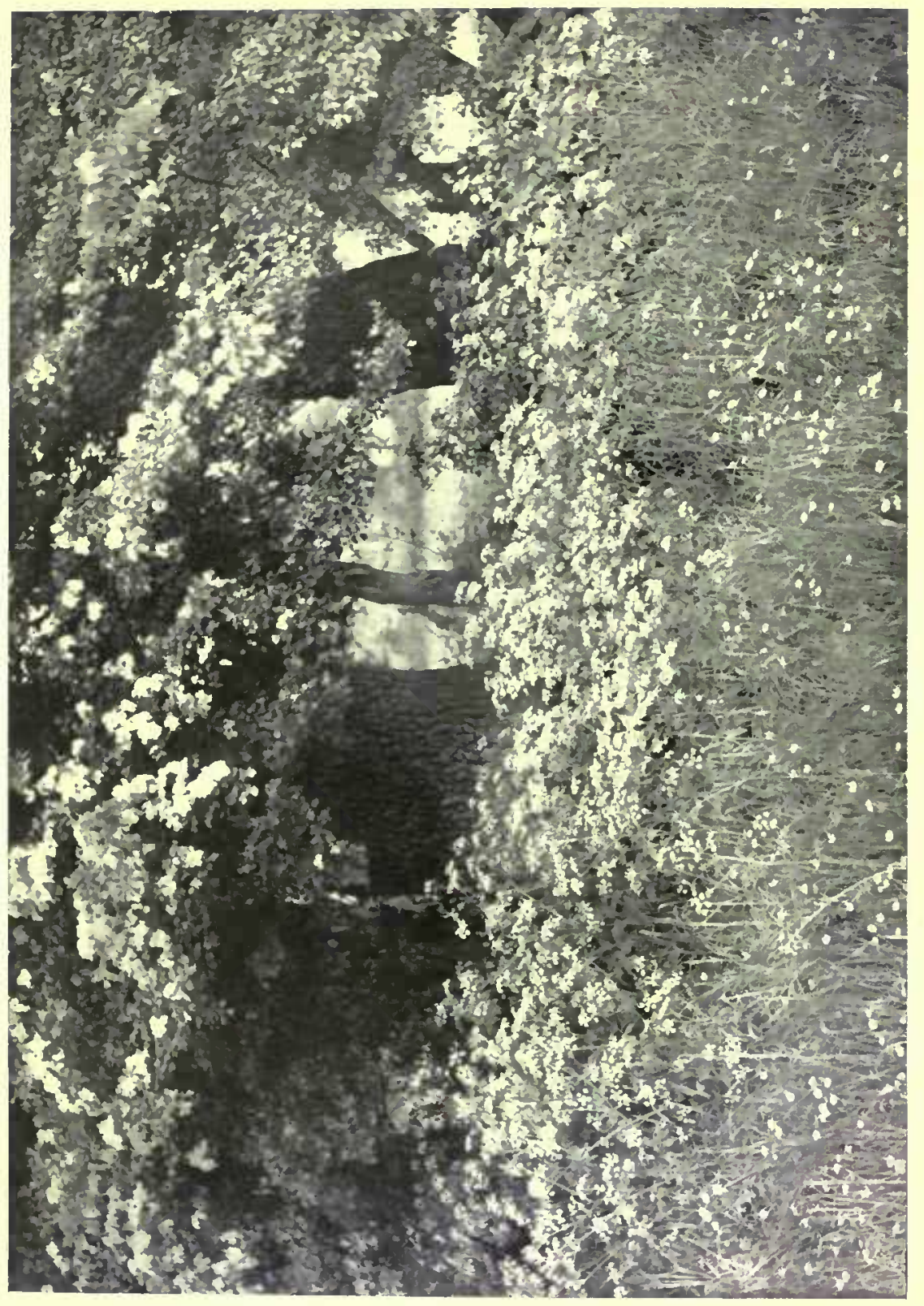

: 


\section{Regressive Woodland}

in which the overwood is allowed to become dominant ${ }^{1}$ need not imply a history of more than 100-200 years.

Admirable minor examples are afforded by the Hinksey 'Ravines'. These represent deep erosions in Corallian strata, three in number, cut in iower parts to the Oxford Clay bottom, to 50-100 ft. deep at the maximum; the bottom swampy, and the sides too steep to readily plough or mow. All were originally well-wooded from top to bottom. The present state of these ravines (especially that of the Chilswell Stream, or 'Happy Valley') epitomizes the story of local woodland. The swampy bottoms give Juncus-association, as water percolates to the clay strata, residual copses are left in isolated patches (Chilswell Copse, Limekiln Copse), but much of the sides has been cleared to be utilized as rough pasture. The slopes show a remarkably clean-cut sky-line, and the ground above (Coral Rag) is arable, and cultivated to the edge. ${ }^{2}$ The grassy slopes tend to revert to thorn-scrub, which may regenerate poor coppice in parts, but in others is kept down by bill-hook. In some more level lower portions, small holders are beginning to struggle with the difficulties of the situation. The 'Happy Valley' is within the range of school-holidays, and is popular on Good Fridays and Bank-holidays.

(I) The Chilswell Ravine ('Happy Valley') is continued up above the Kimeridge Clay at Chilswell Farm to the Greensand of Pickett's Heath, ${ }^{3}$ giving a few distinctive plants in higher parts (Campanula rotundifolia), and poor coppice on the clay (Birch Copse).

(2) The Rifle-range Ravine, north of Chilswell, passes up to clay, over which streams exude giving good Hill-swamp of Equisetum Telmateia, and subaquatics in profusion, with Eupatorium and Orchis maculata; at a higher level Juncetum, thorn-scrub, and on the Corallian characteristic thistles, as Carduus acaulis and C.eriophorus, following on to the bottom of Hen Wood.

(3) The Old Rifle-range Ravine, south of Chilswell, is less deeply cut and cleared. It similarly continues on to the Kimeridge and the derelict coppice of Tommy's Heath to the Greensand of Boar's Hill.

\section{Grassland and the Evolution of Pasture.}

The original formation of grassland, as a special case of Herbaceous plant-growth, follows as a general adaptation to conditions of reduced rainfall and water-supply, involving an amount available in the year less than will support tree-life in close canopy. It thus presents a remarkable example of adjustment to extreme seasonal change, originally expressed as the alternation of a hot and dry period with a short rainy season in tropical forest.

The Grass-type implies the total loss of the primary arboreal factors of erected main axis with cambial increase and a deep-sinking primary rootsystem; the prototype being seen in Bamboos of High Forest, as a special biological growth-form, running parallel with the liana in its capacity for rapid rise to the top of the forest with minimum stem-material, but by a wholly distinct mechanism. A tropical Bamboo may be rushed up ioo ft. in a month of the wet season. The main axis reduces to a more or less horizontal rhizome, giving off erected laterals seasonally, which show no

1 e. g., Oak over Hazel and Bracken, bnt also intrusive Common Elm over Nettles, or alien Sycamore-coppice over Mercurialis.

Cf. Schlich, Silviculinre (19ro), p. 265. The stools of ash, maple, birch, and beech are shortlived, lasting frequently not more than two or three rotations. Oak-stools are practically indestrnctible, and Hazel freely suckers. Hence where there is little planting, Oak-Hazel coppice becomes the end-term of an artificial selection, as a simple matter of survival.

2 Headington Wick, on the Elsfield side of the valley, is a similar ravine, cultivated to the southern edge, but still predominantly coppiced.

The old hill-track to Wootton rises straight pp the Chilswell valley from S. Hinksey, at $200 \mathrm{ft}$., to Chilswell Farm on clay at $400 \mathrm{ft}$., over Pickett's Heath (by Matthew Arnold's tree) to Hill-crest ( $500 \mathrm{ft}$.) on the top of the Boar's Hill Road. 
secondary increase in thickness, but exhibit a marked telescopic growtheffect by the intercalary extension of the internodes of a distichous phyllotaxis-construction; the root-system being wholly adventitious from the nodes, and utilizing surface-water.'

This short-season type, originally a forest-product, thus becomes the colonizer of open country, or savainnah-land, with exaggerated seasonal effect (wet and dry), fruiting with a particularly short vegetative season, and perennating where trees cannot subsist on small supplies of surface-water; hence passing with equal facility to reduced forms of xerophytic grassland, or to the subaquatic life of the water-logged swamp. On nigration to North Temperate regions, smaller and more depauperated types become the familiar vegetation of grassland, enduring winter frost and snow as well as summer drought, vegetating freely over a short period of little more than three months in the year, and utilizing their capacity for telescopic extension for the erection of a short-lived and wind-pollinated inflorescence-system. A closely parallel biological equipment is attained in quite distinct plantseries of the Monocotyledons, as Cyperaceae, Juncaceae, and other families with no direct relation to the Gramineae, to the extent that such forms become characteristic of poor ground, sour water-logged soil, as residual vegetation where little else will grow. ${ }^{2}$

Hence in the migrant flora of a North Temperate country as Great Britain, grass may be taken for granted, as already established, and capable of occupying open land beyond the forest-belt; that is to say, where the tree-canopy fails, grasses will become dominant, both on dry hill-sides as xerophytic forms enduring extreme desiccation as dry turf, and in swampareas as aquatic types mingled with reeds, rushes, and sedges of very similar and convergent biological status. Though there is no direct evidence that open grassland ever existed within the Oxford district, even on the tops of the adjacent hills in post-glacial times, grassland undoubtedly prevailed on the hills of the Chalk at no great distance. Since grasses grow freely where trees will not, any clearing of a woodland area soon results in the production of grassland, which is maintained so long as the woody forms are kept from regenerating. Such grass-tracts by continual cutting, mowing, cleaning, or burning, become the more cmphasized, as further progression of the association is closed, and the conditions for luxuriant grasses are improved; since all grasses, even the most enduring, flourish best in good well-drained and aerated soil. By close-cutting at the soil-level, the majority of herbaceous perennials may be kept down, and the grass-association is improved by agricultural selection, giving the mantle of green turf characteristic of modern pasture-land and even golf-courses. That is to say, the evolution of pasture is the expression of the influence of human agency on the original tendency to open grassland in the absence of trees, now extended to tracts with better water-supply, fully capable of growing trees, but maintained artificially where trees have been denuded. The pastures become the more artificial as they are mown every year at about the same date, levelled, and the time of cutting adjusted to suit the periodicity of some grasses more than others.

In allowing for the present condition of pasture-grasses, it must be remembered that a long sequence of equally migrant races of men have colonized the district, bringing with them domesticated cattle as bullocks,

1 Note that the erected monaxial Zea Mais, familiar as a 'typical Monocotyledon', is a wholly secondary expression derived by agricultural selection as a mutant of Euchlaena mexicana, the multiaxial form of which is cultivated as Teosinte.

For account of the organizalion of Forest Bamboos, cf. Troup (I921), Silvicnlture of Indian Trees, p. 990 ; Brandis (1911), Indian Trees, p. 660.

2 Schimper (1903), Plant-Geography, Eng. Trans., p. 591, General Oecology of Grassland. 
sheep, and horses, all essentially grass-eaters, and thus adding to the factors of the grass complex, as they may prefer distinct types of grass, - sheep the finest, horses the coarsest, and bullocks the most nutritious. By closecropping the grasses they prefer, these animals encourage the growth of new shoots, increasing the vegetative system below the dead herbage, and incidentally supplying manure. To this may be added the question as to how many of these useful pasture-grasses, not available in local woodland nor in swampy bottoms, were really introduced by man from other lands, apart from casual distribution from dry grassland of the Chalk or adjacent tracts.

The chief ecological constituent of the land-area of the district is maintained in the form of broad stretches of flood-meadow following the alluvium on either side of the Isis and Cherwell, broadening into the milelong stretch of Port Meadow, the Marston Fields along the Cherwell, and south of the town in Osney and Christ Church Meadows to the Iffley Fields, over an area of approximately 5 square miles. ${ }^{1}$

As already indicated, in the earlier historical epoch the original facies of the country must have been mainly swamp-forest of dense thorn-scrub, with dominant trees as Ash, Alder, Willow, and intersected by numerous waterchannels carrying a rank vegetation of aquatics and reeds, on clay bottoms difficult to cross, and full of wild-fowl and wild animals.

The clearing of these alluvial flats by early English settlers, who came to find cornland and pasturage for cattle on a larger scale, not only gave the happy solution of the agricultural problem which made life successful in this region, but also affords the clue to the present existence of the city as a market town and University centre. ${ }^{2}$

Whether cleared by fire, or by clear-felling in the approved manner of colonial pioneers to whom timber is mere 'lumber', it is evident that the success of the early farmer depended as much on getting food-supplies for his herds, as corn for his own family. The alluvial flats, dry in summer and flooded in winter, affording green pasture all the summer season, as they do at the present time, even in seasons of greatest drought (192I), also provided abundant hay for use in winter when the floods were out.

Being too wet to plough, the alluvial flats were thus cleared exactly to the flood-line for pasture, and tillage for corn followed the rising levels, on higher clays, bottom terraces of gravel, or the higher outcrops of Corallian soils.

Improved agriculture seeking to ameliorate the damp of winter-flood time, cleared the streams of weeds, opening up the flow of water for mills, giving a scheme of clear open streams, abounding in fish, flowing through broad green meadow-flats, lined with planted willows and poplars, or residual alder and ash retained for a convenient source of fuel and agricultural timber; while the tops of the hills were left as open woodland, predominantly oak, still maintaining game, and affording food for hogs. There can be no doubt that by early Saxon times the district was a model of the agriculture of the period, as a flourishing countryside, peculiarly adapted to the genius of the English race, with wholly indefinite supplies of clear water, and permanent pasture throughout the summer, when other parts of the country were dry and burnt up, as on the adjacent chalk downs.

From the fact that the situation is fairly central for the whole country, with pasturage and water-supply for an army, exigencies of transport marked the town which grew up by the ford on the gravel-bank between the confluence of the Isis and the Cherwell, as an ideal situation for political conferences of the

1 Cf. Plot (1705), p. 52. 'Thongh Oxford, almost in every part where Industry of the Husbandman hath anything showed itself, doth produce corn of all sorts plentifnlly enough, yet it has much more cause to brag of its Meadows and Abundance of Pastures, wherin as in rivers few countries may be compared, perhaps none preferr'd.'

2 Plot, loc. cit., p. 20. "'Twas the sweetness and commodionsness of the Place that (no question) first invited the Great and Judicions King Alfred to select it for the Muse's Seat.' 
day; and as accommodation for horses and retainers within the walls was naturally limited, the broad meadows, especially those south of the town, afforded an ideal eamping ground once the hay was cut. ${ }^{1}$

Comparatively little change has been effected in the general scheme of husbandry to the last century. The meadow pastures are still maintained by the cutting of the hay, a second crop being commonly taken in September, and the fields more or less grazed in autumn and winter. Flooding has been much reduced, and in absence of special manuring the hay tends to deteriorate both in quality and quantity. ${ }^{2}$ Most of the area has been allotted and enclosed. Port Meadow is maintained as permanent pasture, and is grazed by numbers of cattle and horses. Where such pasture-land is not cut, it soon reverts to Funcus-association (Kennington), or to thorn-scrub (Binsey).

The country beyond the immediate river-area is dotted with farmsteads, about $\frac{3}{4}$ mile apart, still maintaining old sites, as indicated by their watersupply from deep springs; though many have been swallowed up in the urban area (Black-Hall) or replaced by institutions. ${ }^{3}$

Other land maintained as pasture, grazed or cut for hay, or cultivated under grass and clover or other fodder-plants, follows the normal evolution of such land, as taken in from the rough common-land or waste.

In mediaeval England pasture-land for grazing and meadow land for hay were held in common, in addition to the very large amount of open waste land utilized for rough grazing, and the same system prevailed to the sixteenth century, or for most of the country to the beginning of the eighteenth. Port Neadow, originally 440 acres, the property of some 500 Freemen of the City of Oxford (and not of the ratepayers), persists as a relic of this system, held since the time of Edward the Confessor; since, as such flood-land was abundant, it was hardly worth taking over by the Norman Governor.

It was not until the provision of fields witl hedges for cattle ('closes') came into general use, that other more definite pasture-fields were isolated. Thus Fitzherbert (Book of Surveying, 1523) recomnsends the allocation of pastures of the communal farm-land into a 'Six-field' system; i.e. giving-in addition to the general Three-field scheme of husbandry of (I) Winter Wheat, (2) Spring Corn, Barley, (3) Fallow-new fields as (4) Best Leys for feeding horses, (5) Rough Pasture for cattle and sheep, and (6) Meadow to be cut for Hay. 'T his would give in practice five fields for winter grazing, and threa (fallow, leys, and pasture) for the summer, with the possibility of alternating the cornland and the pastures in a rotation.

From this time dates the increasing cultivation of pasture and grass-fields, still continued and hedged. The introduction of special fodder-plants from the continent, as Sainfoin, was followed by the general cultivation of 'Dutch' Clover (Trifolium repens), and grass-seeds, more particularly 'Ray Grass' (Lolium perenne). Plot (I 705) is particularly enthusiastic on the cultivation of Ray Grass, and records its introduction to the district by a farmer of Islip. ${ }^{4}$

1 Plot, loc. cit., p. 21, gives a good list of the early Parliaments and ecclesiastical councils beld at Oxford between 1002 and 1250 (22 in number). It was a comparative accident that Magna Charta was signed at Runnymede, 30 miles SE. down the river, in a meadow very similar to Itfley Fields, maintained as mown prasture.

${ }^{2}$ Orr (1916), Agriculture in Oxfordshire, p. 180 , 'very few of the Thames meadows yielding anything more than a ratber small cut of indifferent hay.' Within living record, Marston Meadows, treated with abundant stable-manure, harrowed and flooded, yielded record crops of grass 'chinhigh', probably mainly Dactylis and Arrhenatherum.

3 A typical Oxford farm of 300 acres should maintain 6 families, that of the farmer and 5 labourers, giving an agricultural population of about $60-70$ per square mile, as the limit of the capacity of the land to support. Ashby (1917), Small Holdiugs in Oxfordsbire, p. 177 .

The present district taken as about 30 square miles, carries a population, mostly urban, of about 100,000 , or 50 times more than the land will account for. This sufficieutly indicates the lack of dependence of the modern population on local plant-life, with consequent indifference to its problems.

4 Plot (1705), p. 156. 'It having precedence of all other Grasses, in that it takes almost in all sorts of poor Land, endures the Drought of Summer hest, and in Spring is the earliest Grass of any' : 
The evolution of the pasture-field touches another problem of the countryside. With the decay of the feudal system, and labour troubles following the Black Death ( $\mathrm{r}_{34} 8$ ), a system of enclosure of waste set in, with the formation of cattle and sheep-runs by larger landowners, as the preponderant feature of English Agriculture, which became more intensified in the fifteenth and sixteenth centuries, and has gone on continuously to the detriment of the small holders for many centuries. ${ }^{1}$ As the dispossessed peasantry lost the mainstay of their existence, in the suppression of their 'commoner's rights' to free grazing and collection of fuel from waste woodland, successive enclosures became a fertile source of rebellion and rioting, traces of which are found at the present day. ${ }^{2}$

Pasture represents land set apart for the cultivation of special grasses (though now including clovers of the agriculturalist), just as woodland is set apart for the cultivation of a few kinds of tree by the forester. All other plants come under the designation of 'weeds', some of which may be more injurious than others (Ramunculus acris, Rhinanthus Crista-galli). 'The planttypes of general pasture commonly include some 100 forms, as herbaceous perennials in closest association, leaving no room for the intrusion of annuals, or the establishment of the weeds of cultivated land. The grasses number about 30 . There seems at first no special reason why grasses should be selected as valuable for fodder and hay, more than other herbaceous perennials; but as a matter of practical experience they are found to be so, as grasses again make good recovery, and may be even improved by the closecropping of grazing animals. A few types of the Leguminosae, more particularly the clovers (Trifolium sp.), are in practice the only Dicotyledonous perennials encouraged in the hay-field for their food-value. ${ }^{3}$

The grasses may be distinguished as:-(I) original inhabitants of the Woodland (Anthoxanthum odoratum, Festuca elatior); (2) as probably intrusive from dry grassland areas outside the district (Cynosurus cristatus, Phleum pratcnse, Festuca ovina, forms); or (3) from the Continent by the earliest immigrants bringing cattle. Under this last heading may be possibly included many of the finest pasture-grasses which do not occur in competition with other types beyond the pastures (Festuca pratensis, F. loliacea, Alopecurns pratensis, Bromus commutatus). In more moden times Lolium perenne owes its wide distribution to its early recognition as the most reliable grasscrop on any soil ; while the more recent introduction L. italicum is rarely found far from direct cultivation. Of the origin of the common grasses of

also for 'improving any cold, sour, clay-weeping, ground'; and, it may be adoed, at a maximum growth on the Sewage Farm.

1 Orr (1922), A Short History of British Agriculture, p. 48.

2 The injustice to the coltager when his grazing-rights and fuel-rights of the common waste land were cut off, may be gauged by taking the previous estimate of the difficnlty of keeping a cow on an acre of good pastnre. Such grazing-rights of keeping a couple of cows and 2 or 3 pontes would be equivalent to the possession of 10 acres of rough pasture without expense or responsibility, while the rongh wood would supply the year's fuel. To take this from men already living on a narrow margin as small holders or farm-labourers, implies immediate ruin, which a once-popular estimate of "three acres and a cow' would not go far to alleviate. Hence peasants' rebellions and riots have been the familiar accompaniment of 'enclosures' to the present time: Otmoor, a wet-waste of $2,000-3,000$ acres, was so enclosed (1830), and provided with hedges; tioting took place at St. Giles' Fair. A relic of 'open' Brasenose was fenced in 1922 .

It is interesting to compare attempts at establishing small holders on the land at the present time, with little assistance beyond their own holdings which cannot supply everything in the way of fuel and cattle-feed, and at the same time grow crops. The biology of country-life does not cliange very greatly. According to Ashby (1917), Small Holdings in Oxfordshire, p. 177, short of intensive market-gardcning or ponltry-farming, implying the neighbourhood of a large town, there is no possibility in agriculture of a family existing on less than $3^{\circ}$ acres. Yet $3^{\circ}$ acres was also the average lolding of villeins under the Norman Manorial system with full Common-rights (Orr 1922, p. 23).

i Percival (1910), Agricultural Botany, p. 556. Trifolium pratense, T. repens, T. hybridum T. minus, Lolus corniculatus, Medicago lupulina; as fodder-crops Medicago saliva (Lucerne), Onobrychis sativa (Sainfoin), Trifolium incarnatum, Anthyllis Vulneraria; bence the relalive abundance of sach plants locally is no criterion of their indigenous value. 
the Hay-crop little is known, and in absence of definite information it is usual to assume that they are at any rate 'indigenous' to the country. On the other hand, as a hay-field with a densely-mingled crop of half a dozen or more of grasses, all flowering at the same time, is a biological absurdity from the standpoint of cross-pollination by the wind, this special community of many forms sufficiently indicates the complex origin of the association and its artificial selection.

The Hay-crop follows a distinct succession, and the grass begins to grow in March; the undergrowth becoming thick and the shoots elongating in the early weeks of April, to a foot high at the beginning of May. The species flower out in succession, beginning with Anthoxanthum, ${ }^{1}$ to be followed by first Bromus mollis, Alopecurus pratensis, and Poa pratensis. The last is dominant in the early weeks of May, with addition of Festuca duriuscula, Avena pratensis, Poa trivialis. ${ }^{2}$ The main crop comes on with the flowering of the taller grasses Dactylis glomerata, Festuca pratensis, and Arrhenatherum avenaceum. The closing up of the fruiting panicles of this last form is the sign that the crop is ready. At this time Anthoxanthum and Bromus mollis may have shed their sccds, and be wholly dried out. ${ }^{3}$ In fields which are not cut at this stagc other grasses come on, particularly Trisetum flavescens, Cynosurus cristatus, and the grasses of early July, as Agrostis alba, stolonifera, and Phleum pratensc. Lolium perenue flowers on from the end of May to July with greatcst range; the finest grasses of the Hay-crop, Alopecurus, Festuca pratensis, have the most restricted period, as they have little distribution beyond the pasturcs. With the cutting of the Hay-fields flowering grasses grcatly diminish: a few flower sporadically into the autumn, but these wholly die down by mid-November, leaving the fields bare, though more or less green, over the winter months. The second crop of the watermeadows is usually small in quantity and poor in quality; it commonly contains no flowcring grasses and few flowering herbaceous perennials. Fruiting Leontodon autumnale is charactcristic, in quantity sufficient to tint the field. Only in the extremc casc of late spring floods can it compare with the main crop.

From these considerations it will be seen that the grasses of pasture-land normally present a working-period of just 3 months in the year, from mid-March to mid-June, as compared with the 6-months period of the trees of deciduous woodland. Such attainment of quicker returns, which affords the clue to their high degree of specialization as reproductive mechanisms, extends to the herbaceous types associated with them, in a manner which recalls the association of the herbaceous flora of the woodland with the trees of high-forcst, regarded in turn as the main crop; the ecological intcrests of the agriculturalist being much on a par with those of the forestcr.

Pasture-land may be put up for hay during the growing season, and grazed during the rest of the ycar, or a hay-crop may be taken one year out of two (or more, on poor ground), and grazed the others. Port Meadow has not been cut in living memory. Grazing cattle return a certain amount

1 First-flowering record ranging from April 22, in early sensons, to May 8 in late. Alopecurus pralensis, a more typical grass of the early Hay-crop ranging from May 1 to May 17.

2 Fields are closed for Hay abont the middle of May, as the crop becomes too thick to walk over without damaging it. Fields Irampled over by footballers in the winter may be at this time gardens of flowers.

${ }^{3}$ In the early dry scason of J92I, hay-cutting began June 6 , and the crop was carried as cut. The water-meadows (Iffley to Sandford) were carried by June 21 , and the second crop was saved by Sept. 1 I. In the delayed rainy hay-harvest of 1922 , cutting was general only in mid-July, though the first alluvial field was cut Jnne 12. Later alluvial fields were cut at the end of July and the last Iffley Field (and poorest, below the lock) on August 5, 15,25 , and not all carried until Sept. 5 . On other fields a second crop was iaken in the first week of October. 
as manure; the mass of material consumed by a few horses or bullocks may be estimated by comparing adjacent pastures, one growing a dense crop, the other, with only a few head of cattle, kept wholly bare, with no flowers except a few residual Buttercups. ${ }^{1}$ Where grass has been cut for hay through centuries of agriculture, it is obvious that the continual drain of combined nitrogen, and especially phosphoric acid, may soon become a critical factor for plant-life, rendering manuring essential. For this purpose superphosphate and basic slag are recommended. ${ }^{2}$

The management of Clover-leys, and crops of fodder-plants, as Sainfoin, pure or mixed with special grasses (Lolium perenne, L. italicum) or Clovers (Trifolium pratense, $T$. repens, $T$. minus), follows the same periodicity as that of permanent grassland with its weeds, differing only in the dominance of one or two selected types, and increased possibilities of manuring as these follow in the cultural rotation, and hence becomes the more artificial and 'assisted' by human agency. ${ }^{3}$

It must be noted that from the standpoint of the agriculturalist, the tending and utilization of pasture-land is really the problem of growing a crop of the best feeding-grasses, to which all inferior grasses as well as all herbaceous plants (with the exception of the Clover-class already mentioned) are objectionable weeds. About half the species of grass commonly found in Hayfields are entirely worthless as fodder, and merely occupy the ground which should be available for better forms, apart from the general presence of Carices and $\mathcal{F}$ uncus in low-lying ground. Such weed-grasses include common forms as Anthoxanthum odoratum, Agrostis alba, Holcus lanatus, Aira caespitosa, Avena pratensis, Bromus mollis, Hordeum pratense, Briza media, apart from the intrusives of waste ground and ditches. ${ }^{4}$

In this respect the story of the evolution of pasture runs very parallel with that of the problems of forestry. As the pasture of the past has tended to making the best of a scratch lot of indigenous plants, some better than others, and hence encouraged in a mixed culture; so the future remains with the definite sowing and careful cultivation of either a few types of different succession and degrees of maturation for grazing purposes, with a time-limit, or the production of a pure crop of one form for a definite commercial purpose. $^{\mathbf{b}}$ It is this mingling of the older custom with the new agricultural methods, as in the supersession of ancient forestry routine by more modern continental practice, which renders the present epoch of plant-life in the district so interesting, as being in an eminently transitional phase; though while the degree of success attained by the older methods is known, that of the newer departures still remains highly problematical.

Among the great range of Herbaceous perennials associated with the Hay-crop may be distinguished :-

(I) Those flowering out in early summer before the grass begins to grow (Daisy, Dandelion, Ranunculus bulbosus, Luzula campesiris).

(2) Plants growing up with the grass-crop, with elongated inflorescenceaxis keeping pace with the grass (Plantago lanceolata, Ranunculus

1 The return of excrement by caltle is enormous, thongh it only represents a portion of the material taken from the land. In the dry snmmer of 1921 , with no rain from February to September, all droppings dried on the fields, and thete was practically no decay. In many parts (especially Port Meadow) the gronnd was clistinctly blackened, and there was more dung than grass. At present Port Meadow affords grazing for about 300 head of catlle and horses, also 100 or so geese. p. 213 .

${ }^{2}$ Cf. Orr (1916), Agricultnre in Oxfordshire, for notes on the use of superphosphate and nitrate,

Memoranda of Field and other Experiments, Rothamsted (1900), p. 22, Permanent Grass Land.

9 Percival (1910), Agricultural Botany, p. 558. Grass and Clover Leys of 1-3 years duration.

4 Percival, loc. cit., p. 530.

Armstrong (1917), British Grasses and their Employment in Agricnlture, p. 51.

${ }^{3}$ Percival (1910), p. 565. Mixtures for Permanent Pastnre. 
acris, Chrysanthemum Leucanthemum, Rumex acetosa, Crepis taraxacifolia).

(3) More xerophytic types, flowering after the hay-harvest, in the dry summer when the grass is perennating (Centaurea nigra, Knautia arvensis, Achillaea Millefolium, Leontodon autumnale).

A few types will flower in the damp aftermath-period of September, but the fields are cliaracteristically floriferous only in May and June. ${ }^{1}$

The character of the weed-flora also varies with the nature of the soil and the water-content:-

(I) Damper alluvial pastures with great range of type, and clay pastures above the flood-level, produce spring-flowering Cowslip, Orchis Morio, Saxifraga gramulata, Cardamine pratensis; later with the Hay-grasses Ajuga reptans, Lychnis Flos-cuculi, Rhinanthus Crista-galli; and in summer Silaus pratensis, Scabiosa succisa, Sanguisorba officinalis; together with grasses of subaquatic habit:-Glyceria fluitans, Poa trivialis, several forms of Carex (10), as C.glauca, C. riparia, C. hirta, and Funcus-forms increasingly abundant on more waterlogged soils (F. glanucus).

(2) On high pastures with sandy soils, more particularly of the Corallian series, a drier xerophytic flora predominates, grading to hill-pastures which afford no appreciable crop of hay; characteristic forms are $C$ arduus mutans, C. criophorus, C. acculis, Ononis spinosa, and on exposed areas Helianthemum vulgare, Lotus corniculatus, and Echium vulgare.

(3) Of the larger perennial forms only kept down by rigorous mowing, the more striking are Heraclemm Sphondylizm, Angelica sylvestris, Spiraca Ulmaria, Carduns arvcnsis, C. lanceolatus, and often C.palustris and intrusive Equiseta.

(4) As an interesting special case may be included 'Goose Pasture', as seen at Medley, Binsey, and Port Meadow; characterized by a fine turf, close-cropped, highly manured, with abundant miniature forms of subaquatic habit, I inch or so high, and flowering at this size (Myosotis palustris, Simm angustifolium, Hippuris, Veronica Anagallis, Apium nodiflorum, Ranunculus Flammula, Potentilla anserina.

It is so far evident that the biology of the pastures presents a wide field for systematic ecological study, as each area requires to be taken on its own merits; the possibilities of climatic, edaphic, and cultural conditions are so varied, and the last liable to change in successive years. In past time, for centuries, the greater part of the hay-producing area has been left largely to the chances of nature, with little return, except from flood-water and the dung of grazing cattle, and mown at midsummer by manual labour. Owing to the slow rate of mowing by scythe, and the risk of bad weather when the crop is lying on the ground, the older expression of 'saving' the hay, thus obtained from natural causes, becomes significant. The time for cutting followed the exigencies of labour, and implied further risk. A man with a modern reaper and pair-horse team can cut Io acres in a short day's work, as compared with the older style of scythe-work, in which good men averaged an acre per day. ${ }^{2}$

1 The damper levels give the greatest floral display. Fields on clay and allnvium give stretches golden-yellow in May, with Ranunculus acris; sandy and gravel pastures are later white with Chrysanthemum Leucaulhemum. The foral display commonly diminishes with the growth and dominance of the taller grasses, and such fields may show dull-red with fruiting Rumex acetosa. The finest foral effect has been noted in water-meadows of which the cntting has been delayed by rain until late July (Oxey Mead), when Spiraea Ulmaria and Sanguisorba officinalis become pre-
ponderant.

${ }^{2}$ Mowing was done by piece-work, the men working in gangs, with scythe; a $6 \mathrm{ft}$. man cutting a 6 ft. swathe. A good man is recorded, within living memory, as working from 4 2.m. to 9 p.m., 
The best hay-fields at the present time are those of the broad stretches of alluvium on the banks of the Cherwell (Marston district), and other uncontrolled streams (Hinksey Stream, Cold Arbour). Where the main river is locked and kept at head-water, full water-content maintained above the lock affords a good crop (Oxey Mead, Tow-path fields, and Meadow Lane above Iffley Lock); but a reduced supply below the lock, with low tail-water, implies a scanty yield. The luxuriance of the floral display and variety follows that of the grasses.

\section{Roadsides.}

To the ordinary pedestrian the open roadside plays a part out of all proportion to its intrinsic value botanically and the amount of ground involved, since roads afford the primary means of exploring the countryside, and roadside plants if large enough compel the attention of the passer-by, and even of the motorist. Although suggestively viatical, ${ }^{1}$ such plants do not constitute any special ecological class. It is evident that all roads are not only wholly artificial, but of comparatively recent formation, as also liable to rapid modern improvements. Any plants colonizing the sides must be at best residual strays, or immigrants from fields, woodland, and waste places ; that is to say, all are plants of other stations, finding a locus in these new tracts, and surviving as best they can. It is also obvious that a road open to any considerable traffic offers minor areas of local denudation, as broken ground, in which strays from other stations are again so far humanly assisted in their struggle to acquire some tenure in unoccupied ground.

Where only the merest relics of waste or common land remain, and the fields, pastures, and woodland are increasingly closed to the general public, the foot-paths, way-sides, and public roads remain the station to which the botanical student is increasingly relegated. Hence it is preferable to regard the road-side with its boundary fences as a convenient station for meeting the residual types of other formations, now maintaining a precarious existence, under wholly artificial conditions, and open at any time to ruthless destruction at the hand of any local Road-Surveyor. ${ }^{2}$

The possibilities of the situation are considerable, ranging from a modern urban road with no vegetation whatever, to a primitive country wayside, neglected and derelict, which however economically inefficient as a means of transport, may, in the course of 50-100 years, become a thing of beauty, as one of the most picturesque features of the countryside. Such neglected roadways exhibit: (1) a general regression to grassland, (2) the introduction of thorn-scrub, ${ }^{3}(3)$ passing on to all stages of regressive woodland, (4) affording ultimately an avenue of trees of high-forest, meeting overhead in full canopy, and sheltering a wealth of woodland forms in a humus-bottom.

In mediaeval England, as there were no hedges to the fields, so there were no roads as now considered. Main roads had been constructed by the Romans for military transport, and the partial remains of a Vicinal Roman Road below Shotover, are still sufficiently well-defined to mark the track, though this has been lost in places by ploughing (Stow Wood, Baldon).

In Saxon, Danish, and Norman times, the river was the main line of communication, and local roads were mere cattle-tracks from one township to

consuming in the time a quartern loaf of bread and a gallon of beer, with possibly a dozen pipes of tobacco,

1 Watson ( 1847 ), Cybele Britannica, p. 66, includes 'vialical' with plants of rabbish-heaps and frequented places.

2 Highway Surveyors $(1835)$ can call on the owners of any hedges adjacent to roads to have them 'cut, pruned, and plashed', and the trees lopped and pruned, from October to March.

s 'The wayside where thorns grow up', as a general phase of inefficient husbandry. 
another, foot-paths between adjacent farms and cottages, or bridle-paths through the woodland. The latter leave no trace; though several roads around Oxford suggestively link older cottage-sites, as they follow the course of the same subterranean stream supplying the wells."

Cattle-tracks, broadened $30-40 \mathrm{ft}$, and trampled by the passage of herds and rounded flocks of sheep, mark the main routes to local markets, as indicated by the ford which gives its name to the town. Probably the first foot-tracks followed the sides of the streams, as fisherman's paths of to-day, and along the margin of the winter-flood, thus linking up the flood-line villages, and following on to the gravel-patches available for crossing. ${ }^{2}$

Old roads across country were grassy rides in the waste and woodland, in which, as in the case of pasture-land, the regeneration of trees was prevented, bramble and bracken cut out, as in the present rides through woodland (Bagley). These were not separated from the open country by hedges. In swampy levels attempts at a firm bottom were made by putting down rough wood-faggots (the beginning of a 'corduroy' road); or in worse spots by loads of rough rag-stone, as dug or quarried. As this material sank in the mire, more was added, as in the construction of more modern lines of road without special foundation. Deep ruts were neatly filled with rag-rubble. Similar roads in all stages of evolution persist to the present day as farmtracks: many local farms still have no other approach, and are far from any main road. ${ }^{3}$ Sucl farm-roads in the present amenities of the countryside are increasingly labelled 'private'. The width of these older ways was established when hedges became general in the seventeentl century, at a generous range of $30-40 \mathrm{ft}$. Nain roads with greater traffic are $50-60 \mathrm{ft}$, and the thorn hedges in more modern times may be continued in the actual fence of houses and gardens along the route. Local encroachments on such roads, by ingeniously removing one fence and cultivating up to the other, reduce such ways to field cart-tracks, or foot-paths with a general right-of-way. In such case, a quite reasonable notice to aroid standing crops soon becomes a warning to all 'trespassers'. A 'foot-path' should be wide enough for two men to pass when both loaded with tools or produce, without being obliged to stop and put things down; such paths may be fenced to 6-8 ft.; a 4 -foot way is a nuisance.

At a later date minor commercial transport was effected by pack-horses. All heavy traffic came up the river by barge from Henley, to the early nineteenth century, and the river was improved for navigation, and locked to Oxford (1635) long before roads were taken in hand seriously. Clay was the terror of all older roads, and in clay-areas deep ruts would be cut by heavy traffic, as in shifting timber-trees. ${ }^{5}$ Pack-horse tracks rise in a straight line, over the gravels and sands of the nearest hills, to their destination; as over Shotover on the London Road, over Wytham Hill to Eynsham, and straight up Ferry Hinksey

1 Keanington Lane, Road from Littlemore to Garsiagton, Boar's Hill.

2 Remains of snch paths are seen in the present road from Wytham to Botley, and thence to Ferry Hinksey, continued as a foot-path to S. Hinksey, and then again to Kennington Lane. Remains of a similar flood-path on the Iffey side are seen in Meadow Lane, now cat of by Playing Fields from the approach to Magdalen Bridge.

3 Sescut, Chitswell, Minchery, Blackbird Leys Farms. The present state of the 'Koman Road" and especially the diverticulum to Brasenose Farm, admirably illustrate these older grassy roads, now confined within hedges. These require to be seen in wet winter weather. 'Mad Lane', Cowley, is a suggestive relic; now a back-way continued as an old foot-path over the Golf-course. The - Plaia' of Shotover remains as a part of the Old London Roule, broadened at the top to 75 yds., as if for grazing purposes or camping. Excellent relics of such ways are seen in 'Copse Lane' and 'Marsh Lane', Marston, as sections of an older road to Elsficld. A neglected section of 'Copse Lane' under trees, in wet weather, stilt affords a vivid idea of Oxford clay mire as trodden hy catile.

1 The River-road is interesting because it implies a tow-path and a right of way aloag one side of the river at least; opening this region up to the observer as it passes through pasture-fields of the alluvium, not otherwise readily accessible; though arable fields are more usually separated from the track by a hedge : cf. Meadows of Yarnton, Oxey Mead, Wytham, Binsey fields, Medley fields, Iftiey Fields.

A clean-cut rat in Bagley Wood (1922) on Kimeridge clay was $12 \mathrm{in.}$ deep in the groove of older ruts, or 16-18 inches below the level of the centre of the track. 
Hill to Besselsleigh for Faringdon and the West, with gradients ranging $r$ in 20 and $\mathrm{r}$ in $\mathrm{r} 5$. Such lill-tracks leave little trace, except as a foot-path still in use, and marked on the Ordnance Map. In some cases the surface-stream culverts are still covered by large blocks of stone, showing former care in their maintenance. ${ }^{1}$

All such old tracts revert to grassland when not used; with further regression to thorn-scrub, and regressive woodland on the sides, or where wholly neglected; thus carrying a general woodland flora, ${ }^{2}$ and deteriorating again to the waste from which they were originally isolated.

As opposed to these local and older tracks, main roads came in with the increase of transport and the demands of wheeled traffic in the seventeenth and eighteenth centuries. With no pretence at road-making, it took 2 days to get to London ( 50 miles); and a fast coach to do it (D.V.) in one day was put on as a novel departure in 1667 . 'Tumpike' Acts (r662-r 763 ) gave local authorities power to collect tolls towards the upkeep, and improvements began in the main roads. By utilizing local sands and gravels, the clay-problem was largely solved, and fairly good gravelled primary roads, between the larger towns, were in existence at the beginning of the nineteenth century. But little could be done until the construction of a properly metalled road had been tauglit by Telford and Macadam. The former advocated a pitched stone foundation in the French (Roman) method; the latter thorough draining and an impervious surface. A combination of these methods is preferable on a clay bottom. ${ }^{3}$ Gradients were also reduced, with an approximation to $\mathbf{I}$ in $3^{\circ}$ for horse-traffic, and new roads were cut; e.g. Headington Hill cut down, with a route avoiding Shotover for a new London Road; the Eynsham Road passing south of Wytham Hill, and the West Road to Besselsleigh passing north of Cumnor Hurst. Hinksey Hill, which appears to be unavoidable (maximum gradient $\mathrm{r}$ in $\mathrm{ro}$ ), is not a primary route. At the same time it may be noted that a steep road down-hill to a market-town is less disturbing to market carts going home empty, than may at first appear. 'The 'Botley Causeway', crossing 6-7 streams by 7 bridges (Seven Bridges Road), had been made in $177 \mathrm{r}$, as a new entrance to the town (avoiding lierry Hinksey), and the 'New Road' (1766).

These roads followed the general dimensions allotted to older cattle-tracks, and were metalled down the centre for a width of $\mathrm{r} 6 \mathrm{ft}$. or a width sufficient to let two velicles pass, or only $24 \mathrm{ft}$. in a $60 \mathrm{ft}$. road, leaving grassy residual iracts on either side of $6-7$ to $10-12 \mathrm{ft}$. in $30-40 \mathrm{ft}$. way's." "These side spaces are maintained as beneficial from the standpoint of admitting sun and air to the road-surface, as also affording space for a drainage ditch, channels and outlets, as well as convenient dumping-ground for road-scrapings and mendingmaterial. Only in the immediate vicinity of towns are they further developed as foot-paths. In more important roads such tracts tend to disappear, as more accommodation is wanted for wheeled traffic, and tar-macadam is now taken up to the hedge-line. In the more general case, these grassy sides, blocked by heaps of material, or cut by cross channels, are of little use for footpassengers, and they are allowed to revert to grass or anything that will cover their unsightliness. With complete neglect, they pass through all the

1 Cf. the Besselsleigh path between Hen Wood and Cumnor Hurst, and the 'Ridings' from Headington to Horspath.

2 'Copse Lane', Marston; 'The Ridings', Open Brasenose ; 'Blackberry Lane' section of the Roman Road.

3 Cf. new loop road at Iffley Turn (1922).

1 Such roadside wastes along public roads also express the last relics of 'common land', from which cottagers collect dead stick's, cut fodder, or pasture cattle (under supervision) as they are the last resort of the wandering botanist and gipsy. Ancient common grazing land and open waste presupposed cattle-herds. II ith increasing traffic, and public roads passing over commons, further attention was required to prevent accidents and straying.

Interesting survivals of the ancient profession of 'minder', usually relegated to a small boy, cripple, or the oldest inhabitant, may be still encouraged at Binsey, Medley, and Godstow, at towpath gates. 
stages of rough herbage and regressive scrub to tracts of small flowering-trees which may give a pleasant appearance; more commonly they are allowed to remain as simple waste, harbouring all the weeds of cultivation and the hedgerow, a mass of coarse grasses and larger herbaceous forms (Heracleum, Pastinaca, Carduus crispus, Anthriscus, Torilis). Where the entire agricultural country may appear as a garden, with beautifully clean arable fields under corn and roots--the hedges maintained trimmed to the level of the standing crops, as the regulation plashed thorn-fence--such roadside wastes present a striking contrast, as the last remains of the indigenous flora, which seem strangely out of place in a civilized country.

Roads are again undergoing a system of reconstruction, and tar-macadam solves the problem of dust in summer, as well as of mud in winter. ${ }^{1}$ The dusty roadside was a feature of the nineteenth century, and a relic from the pre-railway coaching day's. Motor-traffic soon requires a road broader even than the old-time cattle-track: an optimum width for main lines of $700 \mathrm{ft}$. has been suggested (France), $120 \mathrm{ft}$. in the Londion area.

The Railway-line dates from 1844 (from Didcot); both the G.W.R. and the L. \& N.W.R. follow the alluvial flats north and south from Wolvercote, and the former to Sandford and Radley, on a low embankment of ballast-gravel and clinkers. This presents little botanical interest; the banks being gay in early summer with Senecio squalidus, Chrysanthemum Leucanthemum, Lotus corniculitus, later with Linaria rulgaris, but apt to run dry in hot sumner. The Wycombe Line through Thame runs on a higher embankment to cross the Thames below Iffley; it cuts tlırough the Corallian rocks and Calcareous Grit before Littlemore, and by a deep cutting and tunnel through the Portland beds and Shotover sands at Horspath. These embankments and cuttings exposing calcareous rocks carry a varied and abundant flora. ${ }^{2}$

The main line down the alluvium, with several bridges over minor streams, cuts the older flood-level into two tracts. That on the west is subject to floods from the uncontrolled Hinksey Stream, ${ }^{3}$ and the railway constitutes an effective barrier to the exploration of the area.

It may be noted that botanical interest centres in the fact that roads are of very modern organization, and have little relation to the indigenous flora. Where the track goes through woodland, it will show along its sides all the charactcrs of regressive woodland; if through arable ficlds or pastures, it will carry all the weeds of these formations, the more as it is less caredfor. As traffic implies denuded ground, 'assisted' vegetation will find a station; hence 'viatical' plants are merely assisted indigenous forms, mingled with assisted aliens-whether brought by wind, or on the feet of men and horses, the mud of cart-whecls, and the hair of animals. The dusty roads of the nineteenth century, with exposure to sun and wind, favoured desiccation, which implics a preponderance of xerophytes in dry summer. Droppings of horses and cattle, adding nıanure to denuded areas, encouraged the common weeds of waste piaces and human refuse, as also salt-storing weeds and aliens. Modern usage of tarred roads and rubber tyres tends to eliminate all plants whatsoever. It is interesting to note that in a modern transitional phase, the Oxford district supplies admirable examples of modern road, as also of all the older types that have been.

1 Cumnor Hill was a mire in 1921 : Hinksey Hill was formerly so dusty in hot summer that one could ride up it and not see others going down.

2 A slight sample of a regressive railway embankment, following disuse, is seen near Wolvercate (Peartree Farm). The embankment approaches to the bridge over the river below Iffley were reconstructed 1922 .

The Railway line was washed out in 1894 , following which the line was raised somewhat, and a series of 20 culverts made in the cmbankment to let the water through (Kennington Lane). 


\section{Crops and Weeds of Arable Land.}

A special type of plant-formation, associated with land under tillage by plough, gives the case of the secondary vegetation associated with agricultural crops. The main crops locally are confined to fields of Wheat, Barley, Oats, Beans and Peas, Turnips and Sivedes, Mangel and Potatoes. No other crop of importance is in present cultivation. Sainfoin, Vetches, Clover and Rye, as fodder crops, follow the type of Hay Pastures. Crops of minor importance are grown, as Cabbage and Lucerne. Wheat is still the most important crop, though potatoes are increasing. ${ }^{1}$

The denizens of arable land come under two distinct headings of (I) the crop, as the plant intentionally cultivated, (2) the 'weeds', as intrusive vegetation, of more or less objectionable character from the standpoint of the cultivator, as the accidentia of the process. The ecology of the main crop is the business of the agriculturalist ; a special study involving the relation of that particular plant in mass-cultivation to its climatic and edaphic conditions; as also its relation to preceding crops in the cultural rotation, and the isolation and breeding of improved 'varieties'. The plants thus cultivated may be definitely aliens of a warmer climate (Wheat, Barley, Oats, Rye), or again the specialized representatives of types more or less indigenous (Turnip, Brassica Rapa; Beet, Beta maritima); the former ccreals with a seasonal periodicity of their own, the latter root-crops of biennials vegetating in the first summer.

Subsidiary forms, associated with the main crop, draining the soil of food-supplies and water, are distinguished as 'weeds'; the object of the cultivator being to eliminate them as far as possible, giving clean ground for the main crop and making the utmost of the ecological conditions of soil and climate.

As all such arable land has at some time been taken into cultivation from cleared woodland or open pasture, the indigenous vegetation may persist to a certain extent; while intrusion from similar pastures, from adjacent woodland, and from residual or regressive flora of hedges, may continually add to the source of weeds. In addition to this, alien seeds are being continually introduced with the seeds of special crops, and other weeds may be introduced from roads and waste places on the feet of men or horses in the process of cultivation. The supply of zveed-vegetation is thus continuous, and follows the exigencies of the agricultural situation. With the elimination of hedges, cultivation of fields as wider tracts of land, complete elimination of all residual indigenous flora, and the preparation of clean seed, the weedproblem is reduced to a minimum. ${ }^{2}$

The special features of such field-crops afford a study of plant-life on a large and most intensive scale, as a pure association of individuals, in which no other organism is considered. ${ }^{3}$ All have been considerably modified from their ancestral forms, and are so far 'domesticated' that they do not again 'run wild' or re-establish themselves in competition with the indigenous fora.

The most obvious character of arable land is the small number of plantforms in cultivation. As in all human efforts at domesticating animals and plants, the tendency is to exploit isolated forms with special characteristics at the expense of the rest of creation; and thus the cult of the horse,

1 Orr (1916), Agriculture in Oxfordshire, p. 195, with maps and county statislics from 18661913.

Plot (1705), p. I 57, records Carthanues sativus, Safflower, cultivated for scarlet dye at Aston, and Caraway at Bampton.

2 Brenchley (1920), Weeds of Farmland, p. 43.

3 Percival (1910), Agricultural Botany, p. 57t. "A very large number of native wild plants, which, although in Nature's great collection of living things no doubl perforn some useful work, are nevertheless from the farmer's special point of view, practically without any appreciable value.' 
bullock, sheep, and pig, runs parallel with that of wheat, beans, turnips and mangel. The ideal of the cultivator is to get one paying crop per season of one variety of one plant; since every additional type adds enormously to the biological complex of the farm, requiring special methods for dealing with it, and increases the intellectual pressure on the cultivator. It is owing to this very fact that the ecology of the agricultural crop becomes wearisome to the outsider; and in walking through a field of corn or mangel, one is inevitably attracted by the intrusive weeds rather than by the crop; because the former by contrast afford the greater variety, may possess a certain aesthetic value, and are admittedly on their own.

On the other hand, it must be remembered that crops are grown as food for the human race or for cattle,--that there is no other way of getting food to keep the race going, and that advancing civilization has been based on the cfficiency of its food-material.

The first cereal food of the human race was undoubtedly the grass Oryza (Rice), easily puddled in a tropical swamp with no agricultural implements, and giving a crop in the dry season of hard grain, capable of indefinite storage and transport with little damage, to be readily converted into good food by the use of a little boiling water.

These factors imply a human society living in a tropical climate with marked wet and dry seasons, as also a knowledge of fire and pottery. From a race of arboreal fruit-eating organism, human beings thus became seed-eating; the greater efficiency following the utilization of the food-reserves of the plantembryo itself, rather than the mere excess deposited in the fruit-wall and devoted to purposes of 'animal-dispersal'.

From such swamps, characteristic more particularly of the alluvial flats of large continental rivers of the old world land-mass, similar civilizations followed around the coast-line, as migrants in dug-out canoes seeking estuaries of other rivers, and so founding the civilizations of the older world. A western Sumerian migration, probably from the Indus-delta, colonized the delta of the Euphrates, and being isolated by deserts, further advance took in the grasses of the sandy hinterland, also capable of being cultivated by the rudest plough as a sharpened stake. From such grasses, Wheat and Barley have more particularly developed as the main food-supply of Western Europe, as civilization spread to Egypt and along the shores of the Fastern Mediterranean to Greece and Rome, and from Tyre to Carthage, to become the dominant food-grains of the dominant races of the present world; as the food-value of the Wheat-grain gives greater efficiency than that of Rice.

The English, in turn, came as immigrants to Great Britain seeking cornland, and the parts of the country too hilly or too stony for the ready cultivation of Wheat, remain to the present day as the 'Celtic Fringe'. The colonization of the prairie lands of Canada in the nineteenth century follows the same succession.

The cultivation of the Wheat-plant is not only the essential basis of modern Western civilization, but it is the foundation of all English agricultural practice. Wheat is still the key-crop of arable land, as arable land implies cultivation by the plough, and the plough was invented for the tillage of Wheat in sandy soil, though now specialized for plants grown in stiff clay.

Wheat, Triticum salivum, comprises many much-modified mutants and hybrids to the number of several hundred, ${ }^{1}$ of a short-season xerophytic and highly specialized grass of the Assyrian hinterland, in cultivation for probably many thousands of years. The prototype, if not actually the Triticum Hermonis of Aaronsohn, still growing wild in Palestine, would be so far similar that the latter may be taken as affording the clue to its special biology, as a plant of sub-desert environment and dispersal. That is to say, it requires a dry hot season for seed-maturation, but sufficient water-supply in the soil during the vegetative growing period.

1 Pcrcival, loc. cit., p. 518. 


\section{Crops and Weeds of Arable Land}

The plant is a typical mediocre grass-form, tillering in field-cultivation to $3-5$ culms, with a maximum of 60-100 when single plants are grown isolated under special conditions, as on a manure-heap. The inflorescences are compound condensed spicate systems; the spikelets, with several flowers, setting $2-4$ seeds each. In the original state the spikelets bore long awns in the manner of Barley (Bearded IVheat), and the main rachis broke up into separate segments for dispersal by the wind (Emmer). Vestigial awns commonly occur on 'Beardless Whcats', and the grain lies loose in the pales and is readily threshed out 'naked'. The seed is sown in early autumn (September), to take advantage of warm rains, ${ }^{1}$ on land ploughed generally following Beans or Clover, in drills 6 in. apart. The seedlings come up in $2-3$ weeks; and by the end of November the fields are covered with a green mantle, 6 in. high. Little growth takes place over the winter, until March; the crop increasing in density during April and May. The tillering shoots send up culms increasing by telescopic extension of the internodes from below, to $3 \mathrm{ft}$. in mid-June. The plants flower at Midsummer (4-5 ft.) and the crop is matured early in August. ${ }^{2}$

As a short-season grass of a warm Mediterranean climate, ${ }^{3}$ the wheat is still autumn-sown: but in a northern summer the vegetating period is extended by 2 months, and the plant is so far an exotic beyond its normal dispersal range, now maintained wholly artificially by man, and not running wild. Seedlings in unoccupied ground, as waste-heaps, may grow more or less successfully a second season, but rarely come up a third. As in the case of the American Zea Mais, the mechanism of auto-dispersal has been completely eliminated in cultivation.

The periodicity involves an autumn germinating season, and a summer growth continued a month longer than the hay-crop of indigenous grasses. Weeds germinate and grow up with the crop in a close association which cannot be weeded readily except by hand and in early stages.

Western civilization is based on the production of food-grains of which Wheat is predominant as alone giving good 'bread', together with Barley as an inferior corn, no longer employed for bread, but essential for brewing beer. The condition of English Agriculture has followed the evolution of methods for dealing with such cereals, and any consideration of the weed-accidentia of the crop requires some historical presentation of the special problems of its cultivation.

Fallow. The ancient barbaric custom of growing corn to the exhaustion of the soil and then moving on, implies a more or less nomadic habit and abundance of free land. More settled civilizations of the Eastern Mediterranean, with clearer ideas of property ownership, introduced the practice of fallowing, with the object of giving the land a rest (cf. the 7 th Sabbatical year in Palestine). In Greek and Roman cultivation a general practice (Virgil) let the land lie fallow, and grow a crop in alternate years. This solved the problem of Fungus-diseases (Rust, Puccinia; Smut, Tilletia; Claviceps, etc.) which inevitably follow a pure successional crop grown on a large scale; as the perennating fungus-spores normally germinate in the succeeding spring, but do not last another year. The herbaceous weeds were probably taken as granted. The common weeds of corn-land to-day are but the same as those of the fields of Carthage and N. Africa which supplied the corn of the later Roman Empire.

As a matter of fact, the exhaustion of the land was due to the great growth of weeds in successive years, and the land becoming 'foul' required to be cleaned. In a field left derelict the alien weeds of cultivation would, in the course of time, go down before the indigenous flora, more particularly the

1 Orr (1916), p. 197. Cf. older cnstom of beginning at the end of July. In the early season of 192 I fields were steam-ploughed for wheat after beans, in the first week of August.

In the dry summer of 1921 , wheat was harvested before the end of July.

3 In Palestine wheat was sown at the onset of the rainy season at the end of October, and grew throughout the mild wet winter, to be harvested in April or early May, as a 6-month crop. Barley, sown in February, less water-demanding, with surface-roots, as a short-season cereal, is aiso harvested in May, in 3 months. In Alaska, with 'midnight sun', wheat is harvested in 9o days from sowing. 
commoner grasses; but a better plan would be to plough the fallow repeatedly to kill successive crops of germinating weed-seeds. The poverty of the crop in this part of the world, as also the general method of fallowing, is indicated by Walter of Henley for the early thirteenth century. Two bushels of grain were used to sow an acre, and 6 bushels is recorded as a satisfactory crop. This probably indicates that less than 6 bushels, e.g. 4 per acre, as only doubling the seed-output, would be the limit before fallowing. The general average yield per acre for England at this time appears to have been 9-ro bushels. ${ }^{1}$

In Saxon times the arable land of a township was held in common, as unfenced 'field', and only enclosed while the crops were standing. After harvest the hurdles were removed, and the field left open for grazing. Cultivation by plough with yoked teams of oxen ${ }^{2}$ implied difficulty in turning, and fields were cultivated in 'strips' of an acre or so. In order that the land of the community might be shared equally, the holders had strips in different parts of the 'field', in the manner of scattered allotments. The acre, expressing the amount of land ploughed by an ox-team in one day, became the unit of land-area, and might vary in different countries; an English acre is half as much again as the Roman. The standard English acre was established as ro chains long ( 220 yards $=$ a furlong furrow), and one chain (22 yards $=$ 4 'poles", "land-yards", or $16 \frac{1}{2} \mathrm{ft}$. spears) wide.

The same method of strip-cultivation was practised in Norman Manors, ${ }^{3}$ and was only eliminated with the decay of the Feudal system. The aggregation of the holdings of the villeins as small holders into associated lots, and the secondary addition of permanent hedges made the more modern farm. The fallow field was ploughed in April, again at Midsummer in dry weather, with a third ploughing before sowing at Michaelmas, thus attacking the successive crops of winterweeds, spring-crop, and summer-crop respectively. This method of 3 ploughings held to the sixteenth century (Fitzherbert), and clearly entailed much labour. ${ }^{4}$

A simple usage, maintaining a balance of the farm between the needs of man and cattle, suggested wheat as the primary crop of first-rate food-material, sown in the autumn, to be followed in the second year by inferior corn as barley, a grass of shorter season, and hence sown in spring. The barley was followed by a fallow the third year, grazed and ploughed, as the 'three-field' system $;{ }^{\circ}$ maintaining one field in each state every year, and a 3 -year cycle for all.

Rotation of Crops. The old fallow was nerely a weed-heap, in which indigenous grasses struggled with the alien flora of the wheat-crop. The addition of grass-seeds would clearly hasten the process; and these when ploughed in at the end of the season, gave the essentials of an elementary 'rotation'. Clover (Trifolium repens) was added to the grass-seeds (sixteenth century), following improved methods from Flanders, and in the middle of the same century Red Clover $(T$. pratense) and Sainfoin became well known, as also the field-cultivation of turnips for feeding sheep, introduced from Holland about 1650.

In order to maintain the balance of corn and cattle-crops it became increasingly general to put turnips and clover between the two standing crops of corn, so that the land was kept fully occupied; the winter wheat and beans being autumn-sown, and the others admitting a certain amount of cleaning in the spring.

The great pioneer scientific agriculturalist, Jethro Tull of Berkshire, ${ }^{7}$ insisted on the importance of cleaning the land by hand-hoeing, and also by the horse-hoe. For the latter he invented the 'drill' ( $\mathrm{r}$ \% O I), and cultivation in

1 Orr (1922), A Short History of British Agriculture, p. 30.

2 Orr, loc. cit., Ploughing with oxen in the Cotswolds, p. 94 .

- Orr, loc. cit., p. 6, Plan of a Manor Farm.

- Plot (1705), p. 245, records three and sumetimes four ploughings for wheat.

- Plot (1705), loc. cit., implies that much land was still 'cast into three fields".

- Plot (1705), loc. cit., describes the use of Clover, Rye-Grass, Lucerne, and Sainfoin, but knew nothing of turnips. J. Bobart sold Sainfoin seed at the Botanic Garden, 169a.

7 Orr, loc. cit., p. 56. 


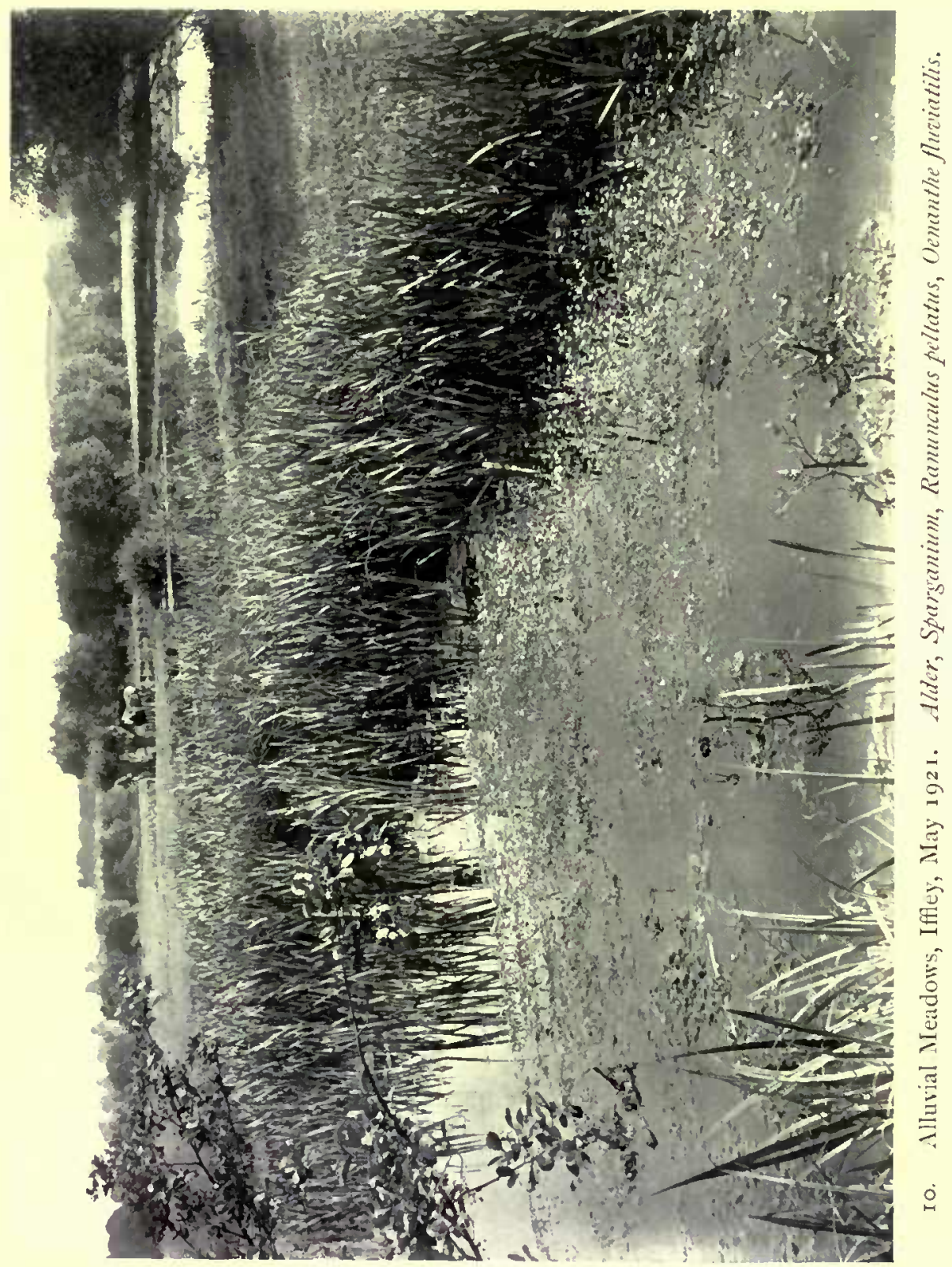




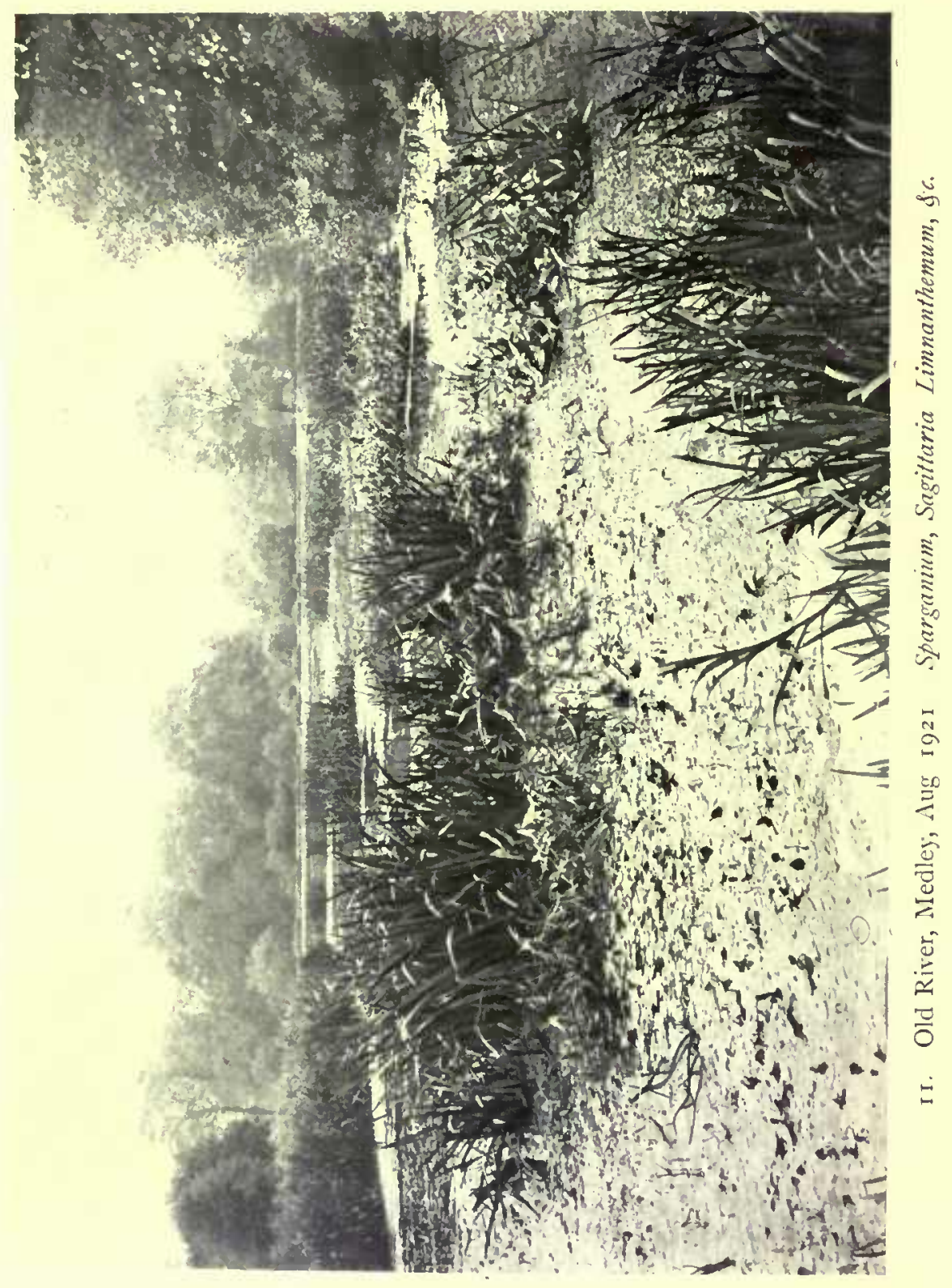


line, as replacing broad-casting. He even grew 13 crops of wheat on the same field without manure, by fallowing alternate strips in successive years.

Early in the eighteenth century, also, Lord Townshend founded the 'Norfolk Rotation', which did away with fallowing altogether, except as a last resource in cleaning badly fouled land. Since by putting turnips after wheat, the land could be hoed and thoroughly cleaned during the summer; and the barley, as before, followed by clover and grass (especially Lolium perenne); the last being ploughed in in the autumn. This 4-year system remains the basis of all rotation of crops; the more so as, since 1886 , the value of green Leguminous crops has been increasingly recognized for increasing the soil-content of combined nitrogen. Modern practice recognizes the great drain of the soil by cereals, not only in combined nitrogen but in potash and phosphates, and these substances may be added as chemical manures. The rotation is also varied, or extended to $7-8$ years, by adding another cereal (e.g. oats), exchanging roots (turnips, mangel) for potatoes, keeping grass and clover for more than one year, changing clover, which may be a failure, for beans, or adding catch-crops after wheat for green fodder.

A general 4 -course system of wheat, roots, barley, clover and grass, may thus become on heavy land a 7 -year system of wheat, roots, barley, oats, clover, wheat, beans, giving wheat the prominence in the succession, as it is the initial factor.

The general principle of attacking the weeds in a low and spaced crop is the essential basis of rotation, and makes it a paying proposition-keeping the land under cultivation for food, and also maintaining a balance between man and cattle. The more exact relation of the wheat-crop to the weedflora has been demonstrated at the Rothamsted Experimental Station. ${ }^{1}$ Wheat has now been grown (since 1843 ) continuously on the same land without manure, and with least fallowing. On the sample $\frac{1}{2}$ acre plot (Broadbalk Field) the yield with no manure at all is still I2-I 3 bushels per acre,an estimated diminution of $\frac{1}{2}$ bushel per year representing the deterioration in the fertility of the soil. Continuous cultivation on an adjacent plot, with manure, maintains a high yield (to $3^{8}$ bushels per acre).

The present average yield for the entire world is given as I 3 bushels per acre. That of the Canadian wheat-fields I6:-for Great Britain 30: for Oxford County 30 bushels and a ton of straw. The best land in England will yield 40, and the maximum recorded is about 60 . The present cost of production runs to $£_{\mathrm{I}} 5$ per acre, as opposed to $£_{5} \mathrm{I} 3 \mathrm{~s}$. in $19 \mathrm{I} 4$. $^{2}$

It follows that fallowing is wholly unnecessary if the weeds are kept down: even the Rothamsted plots, drilled at 10 inches, and hand-weeded in early stages, are by no means 'clean', but show a considerable undergrowth of Poppies (1922).

A new method of attacking the weed-problem is afforded by the use of Steam Tractors : these work more efficiently than the horse-ploughs, to a greater depth, and cutting 3 furrows at a tine do the work of 3 horseteams, or an acre in 4 hours. By such time-saving it is possible to get all the ploughing done as soon as harvest is over, instead of letting it drag on into or over the winter. By steam-ploughing in August or September, the stubble is broken up; and, following mild rain, the main crop of weeds germinates, and may be destroyed by cultivation, before sowing. With this improvement in methods of 'sterilization', and the addition of suitable manures, it will be possible to grow any crop, as required, at any time, and the necessity for rotation also disappears. ${ }^{3}$

As compared with Wheat, Barley (Hordeum sativum) is still more xero-

1 Memoranda of the Origin, Plan, and Results of the Field and other Experiments. Rothamsted, 1900, p. 30.

2 Rothamsted Experimental Station. Abridged Report for 1918-20.

3 Loc. cit., p. 9. Where the ground is good and once clean, using clean modern seed, it is possible to alternate wheat and beans indefinitely, as the weed-problem does not arise. 
phytic, as shallow-rooting, and making less demands on the soil. It produces seed in a much shorter season, and can hence be grown where Wheat fails, and farther north, or on poor land. It is commonly sown in the spring, without special manure, and vegetates 3 months (May-July). ${ }^{\mathrm{I}}$ The yield is about 32 bushels per acre. Oats (Avena sativa) receive little special care, but may be winter-sown hoping to avoid the fly. The average yield is 40 bushels. Beans are commonly winter-sown at 18 in.; they may be hoed when young, but are commonly neglected in later stages. Bcan-fields give usually the finest weed-display of any crop (especially tall red Poppies, yellow Charlock, and white Radish). Hence Wheat following Beans is more likely to be full of weeds, as well as of 'voluntary' Bean. The crop averages 30 bushels per acre.

As an example of a root-crop, presenting a distinct habit of growth and mode of cultivation, the Mangel illustrates the problem of obtaining late feeding-material for cattle and for all kinds of stock, when other foods are poor in quality, rather than for immediate human consumption.

The Mangel ${ }^{2}$ (Beta vulgaris) is an artificially selected form of Beta maritima, a halophyte of the sea-coast, withstanding great exposure and summer heat, so long as it lias a deep source of water; enduring salt soil, and hence useful as a salt-storer, and taking any quantity of manure.

From the wild type which is indigenous, the cultivated form differs in the biennial habit, the erect inflorescence-axis ( $3 \mathrm{ft}$. ), and tendency to store foodreserves in a greatly distended hypocotyl (showing above the soil) and the upper portion of the root. Small greenish flowers are borne in sessile cymose clusters of typically $3(I-5)$, on the panicled inflorescence-axes. The single seed of each flower is sclerosed up with the adjacent ovaries of the triad, to a dispersal-unit thus contairing 3 seeds. These are sown in drills $2 \mathrm{ft}$. apart, at the beginning of May, and the seedlings singled out to distances of I ft. apart. Under summer sun and leat, in well-drained ground with bottom water-supply, growth is rapid, and the crop is matured in autumn; the roots being pulled before severe frosts. The plant is thus given a working period of 6 months, following the general scheme of indigenous vegetation from May to October. The plants are spaced well apart, the vegetative habit being that of a basal rosette, only making close canopy over the soil when growth is particularly luxuriant. The rows may be kept perfectly clean by weeding; but a new crop of weeds begins to grow at any time after rain, the more in dry seasons when the crop is stunted. Neglected fields may give a conspicuous weed-flora in autumn. The average yield for Oxfordshire is 20 tons per acre of 'Yellow Globe'.

Turnips and potatoes as essentially 'root crops', growing in wide rows which may be hoed and weeded throughout the early summer, and are matured late in the season, follow essentially the same general lines; and weeds may follow abundantly as soon as weeding is checked. In gardens and allotments potatoes will grow $3 \mathrm{ft}$. high, and flower, in dense canopy which cannot be hand-weeded after Midsummer; but the growth is so dense that few weeds can endure beneath it. Open fields are conspicuously foul. Neglected turnipfields in autumn may give a wide range of casual weed-flora, and are often gay with blossoms. Turnips should give 13 tons per acre, potatoes 5 tons. ${ }^{3}$

It may be noted that the cereals and beans as standing crops take from the soil large amounts of nitrogenous compounds, phosphates and potash, for the production of seed-reserves, and return nothing. On the other hand,

1 Orr (1916), Agricnlture in Oxfordshire, p. 198.

Plot ( 705$)$, p. I55, records for Oxfordshire a special strain of Ralhe-ripe Barley which was sown and harvested within 9-10 weeks.

The harvesting of the wheat is generally done with a self-blnder using twine, which is estimated to do the work of 10 men old-style: Plot describes the nse of the smooth-edged reaping book; but the sickle has been employed within living memory, or to abont 1850 . Oats have been seen cut with a 'hook and a stick' (1922).

2 Percival (1910), Agricultural Bolany, p. 360.

${ }^{3}$ Orr (1916), loc. cit., p. 204. 
Root-crops, Mangel, Turnips (and Potatoes), not grown for their seeds, but utilized at the end of a vegetative period, take comparatively little valuable matter from the soil, but store photosynthetic carbohydrates as starch and sugar. They usually add to the ground the material of their stems and leaves; and being fed to cattle, much of the material is also returned, and tended in the form of farmyard-manure to the Wheat-crop. The Mangel as a Chenopod, and the Turnip as a Crucifer, are eminently saltstoring and halophytic by descent; hence they will take any quantity of manure, and what they do not use is also left for the next crop.

The Weeds of agricultural land may be classified from several standpoints, more particularly as :-

(I) Grasses and herbaceous plants of pasture-land.

(2) Intrusives from woodland, hedges, and even from boundary-ditches.

(3) Aliens, largely annuals, imported with the seed, or introduced in agricultural operations.

The special ecological factors involved as characteristic of the special associations, may be distinguished as :-

(I) The provision of new and unoccupied ground in optimum condition for the germination of seeds, and over wide areas; hence inviting colonization and open competition, to an extent far beyond anything under natural conditions of the environment.

(2) The elimination of all arboreal forms and larger perennating stocks. Ordinary herbaceous perennials are eliminated by ploughing; only a few residual types with particularly deep rhizomes or roots in the subsoil, or with great capacity for regeneration from cut pieces of rhizome or root, can remain effective. Owing to the great advantage gained by such plants in open competition with mere seedlings, these may in time give rise to distinct races of plant with special aptitude for this mode of existence, and thus isolated by unconscious artificial selection (Dandelion, Carduns arvensis, Convolvulus arvensis, Triticum repens, Equisetum arvense).

(3) With total elimination of arboreal forms and the majority of perennating stocks, the field is left open more particularly for the activity of annuals in greatly increased ratio. The annual weed, in fact, becomes the normal associate of the annual crop.

All field-crops, again, tend to be of annual duration, as worked in association with marked annual rhythm of seasons, allowing the ground to be wholly cleared of waste material at the end of each cropping, weeded, manured, and re-cultivated to give full aeration of the soil. Perennial types (Cotton, Castor Oil, Sugar Cane) are thus treated as annuals for purposes of cropping in the tropics. Annuals are preferred, and the case of the biennial turnip and mangel, utilized for their food-storage in the first year, only emphasizes the point.

The essential factor of such association implies that the periodicity of the weed should run parallel with that of the crop, and different crops will be characterized by their special weeds; though a wide range of plants may attempt to adapt themselves to all. Thus Poppies may colour crops of Wheat and Barley in July, so vividly as to be a feature of the landscape; but are kept down in root-crops by weeding. Rapidly developing Charlock may colour wide ranges of young cereals bright yellow in June; but may similarly colour turnip-fields as aftermath crop in September.

From these general considerations it follows that :-

(1) New ground under favourable tillage may favour plants incapable of holding their own in competition with other forms, in occupied land or the small exposed areas permitted in a closed formation; and such types may persist under the special conditions without ever succeeding in estab- 
lishing themselves in any other. In this way, arable land may come to bear a special flora peculiar to these fields, either predominant, or mingling with residual and intrusive forms of the vicinity, and largely 'alien'.

(2) The greatest success in such association will ensue as the parallelism of periodicity in crop and weeds becomes the more exact; and this will be increased by natural selection, as one type is favoured at the expense of others in coincidence of germination, seed-maturation, and seed-harvesting. The periodicity of each particular crop will be associated with a special selection of weed-plants; particular forms becoming characteristic, and others less so, or rcsidual, as the conditions of the main crop become more precise or more narrowly exacting.

Thus Wheat (Beans and Oats), autumn-sown and flowering in late June, as a tall shading crop, will be generally associated with a class of weeds entirely different from those of Mangels (Turnips) sown in spring, with open distribution, no special canopy, and pulled in late autumn, with little disturbance of the weeds. Spring-sown Barley (Oats), as a tall crop with dense canopy, rapidly maturing (July), may represent a third class of crop, with its characteristic weeds, though combining features of the two preceding types.

But the subject is not so straightforward as this implies; since one is not usually dealing with plants growing continuously in successive scasons on the same ground. If this were the case, the constitution of the association would probably soon become obvious. Owing to general adoption of some form of rotation of crops, the same field does not usually carry the same crop for 2 years in succession; and thus the weed débris of one crop becomes the initial equipment of the next. ${ }^{1}$ New intrusives may be added with the new seed, and a general mingling of wceds result. In such case, shading ${ }^{2}$ and weeding in early stages are the determining factors. The grcatest floral display of the arable fields is given by non-weeded corn-fields in the early stages of their growth (Junc, Midsummer), and again in the autumn fields of root-crops. Casual weeds, flowering and fruiting late in the season, have no chance in a corn-crop, but may grow frecly with mangel (Chenopods, Polygonum). On the whole, neglected root-crops give the greater variety of species, though the corn-fields afford the greater display of individual forms (Charlock, Radish, Poppy). The general list of corn-field weeds comprises about 60 species.

A further source of complication is introduced by the manner in which ploughing operations tend to bury secds at some depth-these remaining dormant through one or more seasons, to be again brought to the surfacc the next time the ground is turned over. The consideration of the weeds of an arable field then implies some knowledge of the condition of the crops for several years previously. Each ficld requires to be taken on its own merits, and over a period of several seasons, the appearance, disappearance, and reappearance of special types being carefully noted. Data require to be collected for (I) The weeds of the main crop ; (2) The special case of plants on any road-track or way across the crop; (3) The plants of the hedges adjacent to the crop. These may be sorted out according to their prevalence in successive seasons, and each field becomes a study in itself. The more agricultural outlook further includes the collection of data showing the rela-

1 Seed-wheat is particularly well cleaned, and common weeds as Poppies, Lychnis Githago, Charlock (Sinapis arvensis), Sonchus arvenssis, etc., are largely residual from a previous Bean-crop.

2 Wheat sown in 6-inch drills gives a uniform mantle over the soil in early stages, and 3 bushels of seed may be used on heavy soils. The same crop might be produced with half a bushel of secd and more scattered plants. A close growth in early stages gives protection, as well as shading of weeds. Broadcasting still gives a more effective smolhering mantle : wide drills only encourage weeds. 
tion of each particular crop to the weed-flora, as also the effect of varying methods of cultivation and manuring.

The case of the perennial weed, and its possible eradication or intrusion, requires to be considered separately for each case. Where such plants produce seed in the first season, they are on equal terms with the annuals. But their method of perennation may have nothing to do with the reproductive periodicity. The case of 3 common species of Equisetum (E.arvense, $E$. fuviatile, E. Telmateia), all freely intrusive from adjacent ditches and damp places, sufficiently emphasizes this point.

Root-crops are grown locally on heavy clay (Kimeridge, Oxford Clay), alluvium, gravel-soils and Corallian: Wheat on all the higher sandy soils of Greensand, Coral Rag, Calcareous Grit (Headington), Oxford Clay and alluvium (Marston), and Kimeridge Clay (Littlemore). The complete history of the weeds of arable land requires a detailed record of sample fields of the different crops in rotation, on different types of soil-formation, continued over several years. The most remarkable display of weeds, for size and luxuriance, in relation to highly manured crops is shown on the Sewage Farm (Littlemore).

\section{Small Holdings and Allotments.}

The case of the small holding follows that of arable land, as a condition intermediate between that of the farm and the garden, in which the factors of plant-association are further complicated by the addition of smaller crops, as fruit-trees, vegetables and flowers of the market-garden, as also by a more intensive condition of culture, by which more than one crop may be taken off the same land in one season. Hence the case of the weeds as subsidiary vegetation becomes morc precarious; exhaustive weeding may clear the ground, and owing to the smaller area involved the labour question is not a serious problem. On the other hand, the weeds become the more luxuriant if weeding is neglected, and the condition of the holding may deteriorate through lack of labour. Such land under private ownership, being less accessible to the general public, may be left with the case of the private garden growing plants of more decorative value under optimum conditions of horticulture. The literature of Horticulture becomes a special subject, as, in fact, also does that of the Allotment. ${ }^{1}$

More suitable for purposes of observation, since also more varied, are the minor urban allotments which have grown up in the immediate vicinity of the town, as a new and probably increasingly important factor in the rural economy. The consideration of their weeds constitutes a special case of those of arable land; the new factors being that ( $I$ ) the crops may be harvested at any time of the year, thus providing unoccupied ground for germination at any month; $(2)$ the crops may follow with any rotation, giving greater possibilities of mixture. The general weed-flora tends to be restricted to a few ubiquitous plants, together with stray casuals which come

1 The expression 'Allotments' dates from the time when allotments were made to the labouring poor at the general enclosing of common lands (1760-1845). Cf. Ashby (I9I7), Allotments and Small Holdings in Oxfordshire, p. 13. 'Except as used for market-gardening or by expert poultrykeepers, there is no method of cultnre which will carry a family on less than 30 acres.'

The term is now commonly applied to plots of 10-40 poles rented to urban population as plots of ground away from the house occupied, for the purpose of growing vegetables. As an institntion such town-allotments began about I $89 \mathrm{l}$, and the area under cultivation increased considerably during the war, laking in Playing-fields, and (temporarily) Merton Meadow. The oldest allotments (Cripley) are now onder distinctly clean cultivation, with much garden flowers, roses and ramblers, to conceal the rndimentary architecture of tool-houses, etc., which constitute a conspicuous, if not always agreeable feature of the suburban landscape.

For data of local crops, and typical scheme of management of such an allotment, cf. Elford and Heaton (1919), The Cultivation of Allotments. 
and go, leaving little trace behind. Strictly speaking, there is not the slightest reason why there should ever be a 'weed' at all in any wellconducted allotment-area; the facilities for checking their growth in manual cultivation being sufficiently ample.

The amount of land locally under such allotment cultivation is already considerablc. The ground had been previously pasture-fields, cut for hay (Donnington), grazed (Port Meadow), used for cricket grounds (Cowley Road), and largely flood-meadows of the alluvium (Osney, Botley), with attempted raising of the lcvel by means of town-refuse (Port Meadow). The oldest tracts and those nearest the city are on the alluvium (Port Meadow Allotments). The soil in these cases is Oxford Clay (Holywell), or with superimposed alluvium, or in the case of Port Meadow, alluvium over terracegravel; at Headington there are extensive allotments on Corallian soils. In all cases the antecedent flora had been that of pasture-land; and with the clearing of the turf, grasses and the wceds of pasture remain to some extent, in the borders, hedges, and foot-ways, while other weeds of cultivation and of human association are introduced. Since such intrusives may become a nuisance, they are regarded as 'weeds' to be kept down by the cultivator in his own interest and also in that of his ncighbours. ${ }^{1}$

Allotment-weeds are chiefly of annual duration (including ephcmerals), commonly growing up with the crop; their maintenance depending largely on the fact that their periodicity runs parallel with that of the cultivated plant; while weeding may be difficult in later stages of growth. With the general run of summer annuals are included some particularly deep-rooted perennials, surviving in virtlie of a decp root or rhizome-system in the lower layers of the subsoil, with great vitality and powers of vegetative propagation,- - the cutting of rhizome or root into pieces by the spade only serving to increase the number of individuals. It is a matter of interest to consider the origin and possibilities of such a flora, its special means of perennation and capacity for rapid multiplication, as much from the standpoint of the remarkable vitality of such plant-forms, as from the converse standpoint of the readiest means of effectively extirpating them. The special equipment which enables such plants to hold their own comprises one or more of the following factors:-

(I) Special mechanism of dispersal, preferably by wind.

(2) Special mechanism of perennation.

(3) Rapid rate of germination in open ground ; i.e. faster than the crop.

(4) Early flowering and seeding, also earlier than the crop, with preferably the monocarpic habit, as using up all available synthesized material in the production of seeds, with extreme wastagecoefficient.

While weeds of arable land may be graded according to their response to ploughing in winter and spring, with two sets of climatic conditions, allotment-weeds may be graded roughly in three such sets, according as :-

(I) They begin as seedlings germinating in spring (April, May) as the first 'main crop'.

(2) Later crops of seedlings germinating in favourable rainy weather in the early summer (June), and flourishing at midsummer.

1 Ashby (1917), loc. cit., p. 20, for general by-law. One derelict patch will infect a wide area, and involve considerable annecessary labour for better workers. Uncultivated allotments become a forest of weeds in early June, already seediag and hiding the soil, and ground is commonly neglected in late sammer. Weeds are soon reduced if the waste-heaps, hedges, and foot-ways, are properly looked after; this being considered beyond the province of the individual holder. Some of the more obvions and objectionable forms shoald be definitely proscribed, and their growth made a panishable offence. At present, plants only become illegal when they act as hosts to some fungus 'disease' of the crop; but attention to a few common weeds for a few seasons might wholly eliminate them from the district. The method bas been tried in other conntries. 
(3) The late crop of September seedlings, germinating in the cooler autumn months, after summer drought.

The first crop gives the summer ephemerals, as also the larger flowering plants of the hot summer (Chenopods, Polygonums) as strays from a warmer climate. The summer crop repeats a further set of ephemerals (Capsella, Veronica); while the autumn crop develops a third set of ephemerals to continue over the mild winter months, as also giving strong growths enduring winter cold to flower in early spring ; many of these being perennials which flower in the succeeding summer (Lamium album, Thistles, Docks).

A general list of Ioo such plants, ${ }^{2}$ grouped according to their special origin, indicates what is really the last stage of the weed-flora, as the hardiest survivors maintaining a precarious existence under human assistance and protection.

I. Pasture Grasses.

Agrostis alba (stolonifera).

Agrostis vulgaris.

Alopecurus pratensis.

Bromus mollis.

Dactylis glomerata.

2. Herbaceous perennials of the pastures.

Achillaea Millefoliun. Leontodon hispidum.

Bellis perennis. Medicago lupulina.

Chrysanthemum Leucanthe- Plantago lanceolata.

mum.

Geranium molle.

Ranunculus acris.

Leontodon autumnale.

Ranunculus repens.

Rumex crispus.

3. Climbers and Trailers from Hedgerows.

Solanum Dulcanara. Galium Aparine.

Calystegia sepium.

4. Plants of the Roadsides and Waste.
Bromus sterilis.
Pastinaca sativa.
Capsella Bursa-pastoris.
Daucus Carota.
Hordeum murinum.
Melilotus officinalis.
Plantago major.
Potentilla anserina.
Lapsana communis.
Potentilla reptans.

5. Human associates.

Senecio zulgaris.

Senecio squalidus.

Stellaria media.

Cardamine hirsuta.

Diplotaxis muralis.

Anthriscus sylvestris.

6. Weeds of arable land.

(Voluntary) Wheat.

Barley.

Oats.

Sonchus oleraceus.

Anthemis Cotula.

Matricaria inodora.

\section{Casual Aliens of no fixed tenure.}

\section{Solanum nigrum.}

Trifolium arvense.
Poa anmaa.

Poa pratensis.

Poatrizialis.

Taraxacum officinale.

Trifolium minus.

Trifolium pratense.

Trifolium repens.

Nepeta Glechoma.

Rumex obtusifolius.

Sisymbrium officinale.

Urtica dioica.

Atriplex hastata.

Atriplex patula.

Urtica urens.

Lamizm album.

Lamium purpureum.

Lamium amplexicaule.

Veronica Toumeforlit.

Veronica hederaefolia.

Polygonum Convolvulus.

Raphanus Raphanistrum.

Sinapis arvensis.

Papaver Rhoeas.

Aethusa Cynapium.

Chrysanthemum segetum.

1 The list is not exhaustive, and the sub-sections are somewhat arbitrary; bnt it is intended to include the commoner forms found growing in local allotments, and to indicate a method of subdividing a mass of types into more convenient ecological groups. 
8. Garden Strays, of casual occurrence.

Reseda odorata.

Mentha viridis.

Foeniculum officinalis.

9. Residual Swamp-flora.

Typha latifolia.

10. Specially deep-rooted or rhizomatous plants, defying extirpation.

Convolvulus arvensis.

Circaea lutetiana.

Aegopodium Podagraria.
Agropyrum repens.

Carduus ariensis.

Tussilago Farfara.
Polygonum amphibium.

Ranunculus Ficaria.

(Equisetum arvense).

As in the case of arable land, the chief interest of the botanist centres in such despised weeds, rather than in the crops of the allotment-holder,the former presenting the greater variety of habit and organization, as also being entirely on their own, and fighting the last losing battle against domination by man, - the latter, on the other hand, comprising tame and domesticated races, spaced each in their own ground, wholly dependent on human assistance for their origin and racial progression, and in a majority of cases never working out their reproductive cycle, but cut or 'pulled 'as the 'crop', when they attain a certain stage of vegetative maturity; to the extent that the life of a cabbage becomes a byword of biological reproach.

Waste Heaps and Derelict Ground. The débris of a modern town includes an enormous amount of waste material, the rejcctamenta of the human population and dwellings, as ruins of buildings, collections of brickbats, stones and soil, to which is added in the present generation, stores of paper, tin cans, broken glass and rusty iron. Such rubbish-heaps, casually manured, with little good soil, but effective drainage, constitute a nidus for weeds of all descriptions.

These differ from the case of gardens and allotments, in that the intrusive plants are not going to be eradicated; but, if anything, are regarded as the happy solution of the problem of hiding such waste from sight; at any rate, with the result that the sordidness of the landscape is less obtrusive in the summer than it is in winter, as the material becomes increasingly hidden beneath a mantle of something green. None of such waste-heap flora attains any conspicuously aesthetic value, though screens of Privet, annual Impatiens Roylei and Scarlet Runner Beans are freely employed in gardenconstruction. Such waste-heaps present ground which may be unoccupied at any period of the year, usually amply drained, though with feeble watersupply, commonly of fouled soil and hence suitable for colonization by representatives of the more characteristic families of salt-storers and xerophytes (Chenopodiaciae, Polygonaceae, Cruciferae, Caryophyllaceae); and annuals of these groups are commonly the first invaders to take control of the new site. Being commonly near human occupation, and in sheltered situations, they afford a sanctuary for refugees of all kinds, as escapes from garden-cultivation, and alien weeds of a warmer climate vegetating in the hot summer. Hence such localities become the happy hunting-ground of scekers after 'adventives'. Almost anything may grow on a waste-heap from huge plants of Helianthus annuus (giant strain, capitulum 22 in. diam.) to Cucurbita, Datura Stramoninm (setting 75 capsules), Zea Mais, Wheat, and even Phoenix (germinating from casual datc-stones, in quantity, to the 3rd leaf). $\quad$ The first annuals, as Poa annua, Capsella, Chenopodinm album, Polygomum aviculare, give place to Nettles, Docks, Plantains, coarse grasses (Dactylis, Bromus sterilis, Hordeum murinum, Agropyrum repens), and a wide range of types soon get together as samples of a struggling flora, which come

1 Town waste, utilized as the basis of allotments in Port Meadow and Osney allotments, gives large nnmbers of Apple, Pear, and Cherry seedlings, some of which have grown to fruiting trees. Perhaps the most interesting case is the large number of Tomato plants coming up among the Mangels, and even in the hay-grass of the Sewage Farm. 
into active competition for water and free room to develop. As the perennating stocks accumulate dead leaves and dust, worms become active, the soil grows, and in a few years the débris may be completely covered with a weedvegetation which is in turn dominated by grasses, and in the course of time will give turf of grass-land ultimately regressive to thorn-scrub (cf. Rubbish heaps of Headington Quarry).

The stages in such a progression afford an interesting study from the point of view of the time taken, and the use of such vegetation in the often insistent problem of covering up the inevitable waste of civilization.

As a special case, more removed from the immediate vicinity of human occupation, may be included the Hayrick Site. In all pastures cut for hay, the usual practice is to have the rick in the corner of the field most available for transport, to save labour at harvesting. Hence in most hay-fields there is a space marked off as a site for one or more ricks, as the crop is cut in successive seasons, and is not necessarily sold or utilized. The fate of such areas affords a few points of interest. Originally taken as the most convenient, and in low-lying meadows the highest spot for the sake of drainage, and often built on a brushwood bottom, the rick begins by wholly killing off the plants beneath it; and when it is removed, presents not only a denuded area, but one well-enriched with accumulated débris and the washings of the waste. As soon as the site is exposed for new colonization, it is covered by a particularly luxuriant growth of weeds; and such sites become the best grounds to search for local intrusives and samples of the weeds in the fields around.

Rank growths of Nettles, Docks, Chenopods, Atriplex, Polygonum, Senecio, Taraxacum, Poppies, Plantains, Raphanus, Sinapis, Arctium, and Carduus, spp., are especially characteristic, with equally luxuriant grasses as Dactylis, Arrhenatherum, Alopecurus, Agropyrum, Phleum, etc., all doing so much better than in the open pasture, that they attract attention, and one visits such localities to find species making good specimens. These sites are often strikingly conspicuous in the summer, affording a blaze of scarlet Poppies, yellow Charlock, white Radish, and mauve Carduus arvensis, in close association with adjacent arable crops which may be fairly clean, and for which they provide a continuation of the weed-flora. These give place to biennials, flowering the second season, and perennials. Keck, Thistles, Docks, Heracleum, long hold their own, though the grasses become dominant in the long run. Mowing will put an end to the larger growths more rapidly; and if seedlings of thorns are kept down, the site returns to normal pasture in the course of time; though it may be long marked as a slightly raised area on which the grass grows stronger and of a deeper green.

Corresponding stations based on manure-heaps of a rable ficlds, or general fieldwaste, may present similar phenomena in an exaggerated form. But such plants of cultivation and aliens do not invade the pastures. 


\section{River and Ditch Flora.}

The control of the aquatic vegetation is less marked than that of the land-surface exploited for crops; but effects due to interference in special cases follow the normal ecology of ponds and ditches, where these are to be drained, or partially cleaned to maintain the flow of the water; as even the locked river may be let out in sections when the locks are being repaired or enlarged, and a channel is kept free of weeds for navigation.

Cleaning the main river takes place in late summer, or when the vegetation has reached its maximum (July-Aug.); enormous quantities of weed being collected into barges, the cutting being effected by pulling a dragknife over the bed of the stream. Notices by the Thames Conservancy prohibit such weeds being left where they may decompose and contaminate the water. The material, collected to the extent of many tons, includes dense growths of trailing Pond-Weeds (Potamogeton lucens, perfoliatus, pectinatus, etc.), together witl stretches of submerged leaves of Sagittaria, Scirpus lacustris, to a less extent of Oenanthe fluviatilis and Elodea, as well as intrusive vegetation from the bank-side, cut by hook (Sparganium ramosum, Acorus Calamus, and rhizomes of intrusive sub-aquatics as Epilobium hirsutum, Lycopus, Agrostis stolonifera). As these plants are largely rooted in a gravel bottom, sucn cleaning does little to affect the buried rhizomes, and little damage is really done to the flora; the vegetative growth being renewed on a cleared site in the succeeding season. ${ }^{1}$

Branches of the river utilized as Mill-strcams (Wytham and Osney Stream, The Old River) were formerly kept clean by weeding once or even twice in the course of the summer. Now they are much neglected; the town-mills are supplied with water taken off at Medley, and others have auxiliary power. Such streams, left uncleaned, fill up with dense growths of Sagittaria, Sparganium ramosum, S. simplex, together with Nuphar and luxuriant intrusive bank-growths of Epilobium hirsutum, Rumex Hydrolapathum, Sium angustifolium, Carices and Scirpus, or may be readily blocked by fallen Willows. When wholly neglected and stagnant, they give Batrachian Ranunculi, and a dense mantle of Lemna-forms ( $L$. minor, $L$. trisulca, Spirodela polyrrhiza).

When kept well-cleaned, providing a good fast-flowing stream of clear water over a gravel bottom, such ditches produce a quite distinct flora, vegetating actively in early spring, and filling up with a dense growth, as banks of Callitriche verna (3-6 ft.), stretches of submerged Ranunculus trichophyllus, with Oenanthe fiuviatilis, Elodea, Myriophyllum and Ranunculus futitans; as also algae as Chara, Vaucheria and Enteromorpha intestinalis in long trails (3-6ft.). A good example is afforded by the Railway ditch alongside the Willow Walk, when cleaned out in summer and giving a new crop of clean aquatics over the mild winter-months.

As an example of a wholly artificial construction, the City Reservoir, adapted from pits formed by removing ballast-gravel to make the Railway embankment, at Hinksey, is of particular interest. In late summer it commonly affords a remarkably beautiful collection of wholly subaqueous vegetation, growing in fairly still clean water, at a depth of 6-1o ft. When the surface is quiet and the sun shining brightly, massed growths of submerged leafy shoots of Callitriche, Oenanthe fuviatilis, Myriophyllum, and Nuphar, are shown, together with the vertically erected foliage-trails of Polamogeton lucens, $P$. perfoliatus, and the similarly erected cable-petioles of Nymphaea alba (alone flowering at the surface), also the conspicuously erected foliage of submerged Scirpus lacustris and the ribbon-leaves of Sagittaria.

1 This is particularly striking in the case of Nuphar, the stout thizomes of which form a solid mat at the bottom of the stream, and only the leaves and fowers are cut away. 


\section{The Regression of Cultivated Land.}

Recognition of the fact that the general aspect of the landscape of the modern countryside expresses the modifying effect of human activities on the original flora, continued along closely similar lines of copse, woodland, pasture, water-meadows, and arable land, for a period of at least several hundred years, leads to the suggestion as to what would happen if cultivation ceased, and the land were allowed to lapse again to a wild state. In how many years, for example, would land go back to the condition described as primitive woodland? The problem may be approached from several standpoints :-

(1) The reversion of wet flood-meadows and fields of the alluvium.

(2) The regression of dry hill-pastures.

(3) The regression of fields on clay (Oxford and Kimeridge), or on low gravel-terraces.

(4) The colonization of wastc-heaps, including quarry-banks, already indicated.

(5) The complete covering of ruins, and all remaining traces of human occupation.

Examples of all these phenomena are of general occurrence, and from them it is possible to obtain an idea of what would happen if the entire site of Oxford became derelict, and vegetation again asserted itself.

The first case is afforded by the neglect of hay-pastures and dry fields affording little feed for cattle. The clean grassland of the meadow floodarea, and of hay-fields generally, is maintained by the agency of annual mowing, whereby the shoots or seedlings of woody plants (Elm, Poplar, Thorn) are kept down, as are also the late summer-growths of thistles of the dry season. Flood-meadows are subject to free invasion from the hedges by suckers of Common Elm and Gray Poplar, for a distance of 20-50 yards from the tree, and these as a rule are not touched by grazing cattle. In the same way damp clay pastures producc seedlings of Crataegus, and such thorny shoots are also avoided by cattle, growing $2-3 \mathrm{ft}$. in the first two years if not mown over. Hawthorn is followed by Rose-briars, by intrusive Sloe from the hedges, locally by Ononis spinosa, and to a much less extent by Rubus which prefers leaf-mould. All these plants are spinous and are rejected by cattle. As the larger forms become shrubby, cattle graze around them, thus rounding off the bushy growths to compact oases of thornscrub. Where there is no grazing the thorn-growth may be fairly uniform, soon becoming impenetrable.

Good examples of the first stages of Thorn-scrub are afforded by poor pastures on Kimeridge Clay (Iffley, Sandford Brake, Cumnor Hurst), and on Oxford Clay (Binsey). The derelict Marconi Station on Cumnor Hill (Coral Rag), gave close thorn-growth to $5 \mathrm{ft}$. high in 3 years, having been sown from an adjacent hedge by strong winds for a distance of 50 yards.

The thorns may thus give isolated tall bush-growths, $10-20 \mathrm{ft}$. high, with little else but Briars and Brambles (Headington Quarry, Magdalen Bridge Scrub); soon becoming impenetrable where grazing is wanting (Chawley Hurst Scrub, Sandford Brake Scrub); the ground-flora of grasses and herbaceous plants being comparatively little affected until canopy is complete.

With the action of cattle in 'rounding off' the patches of scrub, other plants are protected at their margins, afforded free light, and incidentally manured; Nettles, Thistles, Solanum Dulcamara, rough grasses of the hedgerows, Bromus asper, and Umbellifers as Anthriscus sylvestris, Heracleum Sphondylium, Torilis Anthriscus, reproduce the flora of the Hedge-associations, and further stages follow the general lines of regressive woodland. Good 
examples of the drier well-drained stations are seen at Headington Quarry; in the damper levels of the alluvium, Elm, Ash, Poplar and Willow follow on in the course of time.

Dry high pastures on light sandy soils produce Gorse and traces of Heather (Pickett's Heath, Bagley Wood), but the latter is conspicuously deficient in the district, and even Gorse is scanty. Wet, low-lying undrained tracts produce funcus, also dominating the ground-flora; but Juncus, owing to its close growth, affords little opportunity for the germination of tree-seedlings. Willows and Alder are more usually added as they germinate at the flood-line on river and ditch-bank.

An interesting example of the later stages of Thorn-scrub, with Bracken and broad-leaved trees, is seen at the University Enclosure, Shotover, no longer grazed. In many parts the tree-canopy is making close-contact, and the Bracken is dominant in the interspaces. To the trees are added Ash, Oak, Sycamore. The progression has been hastened by the planting of additional forms (Pinus, Populus, Pyrus Aucuparia, P. Aria), but these are still small, and the effect of Oak-Bracken Woodland, with its usual associates and subdominants, is within reasonable view, so long as it is let alone.

Although the general phases of retrogression can be thus indicated by the comparison of local examples, direct observation and record of special tracts over a period of many years will be of greater value. It is in this respect that departmental organization is essential. It is in fact the business of a Botanical Department to keep such a record of local changes, probably never so rapid or far-reaching as at the present time, by which the general aspect of the surrounding country has been completely changed within living memory.'

1 To those who mourn the past rather than praise the present, the verses of Matthew Arnold afford a melancholy review of changes for the worse. A more progressive generation will acclaim the great increase in the population, with associated gas-works, water-works, railways, marketgardens, allotment-areas, not to mention the new Corporation and Rural Council houses, the tarred roads and the fast motor traffic, which now dominate the outskirts of the City.

There is little detailed information as to the condition of plant-life in the district in early times, heyond a few referenees in Plot $\left(10_{5}\right)$, and what can be gathered from Sibthorp (Flora Oxoniensis, 1794), with the localities given for a large number of forms now extinct.

Mediaeval seholars entered Oxford over Shotover, down a horse-path through the thick forest to Magdalen Bridge and the East Gate of a walled city. Even the traditional Oxford Country of Shelley and Matthew Arnold in the early nineteenth eentury has been greatly ehanged during living memory, and it will be probably increasingly improved by speculative building in the next fifty years.

Since 1850 , the introduction of the Kailway, by solving the problem of food-transport, in quantity far beyond the capacity of the local area to supply, has affected local architecture, as well as the general conditions of agrieulture. Until this time, Oxford was still in its main aspect a mediaeval city; on all sides, except where it touched the railway, the city area terminated abruptly, and one came suddenly to meadows. The poorer streets were faced with wash and 'pebble-cast'. Beyond Magdalen Bridge, Iffey Road was bounded by corn-fields, and unenclosed meadow stretched to Littlemore.

Children no longer gather violets in the Iffley Road, within sight of Magdalen Tower ; nor do budding botanists seek 'the lone alehouse in the Berkshire Moors'. Snrrounding villages and farms (with few exceptions) express rather the decadence of an older system of agriculture than any modern efficiency. It is already eurious to read of Dr. T. Arnold (18I9) expressing a wish to take 'one more look at Bagley Wood, and the pretty field and the wild stream that flows down between Bullingdon and Cowley Marsh', or 'the little valleys that debouche on the valley of the Thames below the Hinkseys'.

Two well-knownelegiae poems of Matthew Arnold-- The Scholar-Gipsy' and 'Thyrsis' (I 861)are valuable as depicting, among a somewhat muddled blend of classical allusion, the general aspect of the open country around Oxford in the early nineteenth century. A tree is still pointed out as the 'Glanvil Elm', 'Umbrella Tree', or Matthew Arnold's 'signal tree', a conspicnous landmark on the hills to the west 'bare on its lonely ridge'. A favourite walk of this time was to follow the old pack-horse track straight up from South Hinksey over Boar's Hill to Wootton and Besselsleigh. On tuming down Lake Street from the Abingdon Road, this tree is curiously centred at the end of the vista of small houses and the Waterworks, and on crossing the 'Lake' (City Reservoir), and the Railway (by 'Jacob's Ladder'), is still straight ahead on the edge of the ridge. Passing over the causeway ('Devil's Backbone') to South Ilinksey, and going up through the crops (mangels, potatoes, and barley) of the small holders, the tree is again centred at the top gate to the "Happy Valley'. The path continues past Chilswell Farm, rising over the hill (400 ft.) formerly used as a Golf-course, and ahead will be noticed a conspicuously isolated tree, standing out against the sky, in the hedge-waste about 150 yds. left of the foot-path.

The tree is a tall, badly stag-headed Oak, pillared with epicormic shoots, the trank $2 \mathrm{ft}$. in 
As examples of minor changes, affecting easily accessible stations within the current year, may be instanced:-

The Fencing of 'Open' Brasenose: The extension of the Golf Course over Lye Hill, replacing pasture and arable fields: The cultivation of Bullingdon Bog Valley, and the drainage of its lower portion: The Reconstruction of Iffley Mill Weir: The clear-felling of a quarter of old Wood (Milestone Piece), Bagley Wood: The extension of allotments at Manor Road (flood-pasture): The Council Houses in Iffey Road, Cowley Road, Abingdon Road, replacing pasture fields: The New Loop and extension of building at Iffley Turn, in pasture fields: The reconstruction of the Railway Bridge over the Thames, with denudation and remaking of embankments : The first appearance of a notice against Trespassers on 'Private Land' of a meadow in the Iffley alluvial area, as also on the scrub-covered rubbish-heaps of Headington Quarry.

The conventional notice, which has no special legal significance, may be merely a crude threat to unwelcome strangers, or a method of evading responsibility for their welfare; but often merely expresses a dog-in-themanger type of mentality, and the addition of barbed wire is a deliberately unfriendly act.

\section{ALIENS AND ADVENTIVES}

By an alien is conventionally understood a plant which is known to have been introduced by human agency, or preferably a plant which is associated with human occupation of land. The term is wholly mctaphorical, and like other metaphorical expressions is likely to be misleading. To previous generations the gencral idea sufficiently distinguished between plants which werc assumed to be 'native' or 'indigenous ' to the country, and others which came in from foreign sources; this general impression following from the conception that native plants were created, or at any rate ' evolved' in the land where found. The fact remains that all plants in this country are immigrant at some time or another; the expression alien is purely relative, as applied by the race in possession to the race that is coming. The Englishman who assumes that he is a native of this country was as alien to the older Celtic races, as any representatives of the interesting civilizations of Central Europe may be to us at the present day. So long as the period of human occupation of the land was considered from the standpoint of the historical epoch of 2,c00 years, the term alien merely expressed a plant of which there was some evidence of introduction during that period. With the extension of the time during which man is known to have lived in this country to something like 50,000-100,000 years, the subject takes on a much wider aspect.

Older attempts at analysis of this problem have attempted to grade plants as native, denizen, colonist, alien, ${ }^{1}$ according to degrees of establishment; and the term alien is generally retained to cover all the cases of forms which have come in with the aid of man, to become more or less naturalized. The term 'adventive' conveniently meets the case of those whose importation is so casual and so recent that they have so far not had time to show

diameter. One comes immediately to barbed wire, the cultivated arable fields of Pickett's Heath and houses. The track continues on for half a mile to meet the main road at Hill Crest ( $500 \mathrm{ft}$.), and a pilgrimage of disillusion ends appropriately at the 'Boar's Hill Shop' (Howard and Nicholson, Licensed to sell Tobacco and Methylated Spirit). There is no other 'signal elm that looks on Ilsley Downs', and the spirit of the generation that prompted these lines is now something less than the shadow of a dream.

I Watson (1847), Cybele Britannica, p. 63 . 
what they can do. The subject of aliens in the widest sense is of special interest, as it opens up views of the migration of plants, and the complex factors involved in determining the chances of their failure or success in becoming established.

Bearing in mind the original condition of the country, as covered with dense forest, bare heaths, and downs, populated with the slowly returning representatives of the deteriorated post-glacial flora of Central Europe, it would appear that all special pasture-plants, all the weeds of arable land, all crops, garden-plants and flowers, as well as many valuable timber-trees, are open to the suspicion that they have been at some time intentionally or unconsciously introduced by man. The difficulty will consist in isolating such forms when well-established, and the records of the historical epoch are of more definite value. On the other hand, historical references are often merely negative, as suggesting that the plant was not commonly known to the writer before a certain time, and usually to one whose botanical knowledge of the country as a whole may have been extremely incomplete. ${ }^{1}$

The simple lines of alien migration may be checked from the behaviour of common garden-plants of known introduction. Thus Enonymus japonicus, a common evergreen, does not flower locally, although it does so freely in the S. of England by the sea; other plants are cultivated because they flower freely (Fasminum officinale, F. nudiflormm, Forsythia), but never, or only very exceptionally bear fruit. Other plants appear to fruit, but the seed is imperfect or wanting (Populus nigra, Liriodendron). All such plants are evidently introductions which will never make good; they remain dependent on the hand of man, and require to be propagated vegetatively, unless grown from imported seed. All trees and plants similarly non-flowering, nonfruiting, or producing only occasional seeds, even if found growing remote from cultivation, must have been similarly introduced at some time. Even in the casc of plants occasionally fruiting, there is the further problem of seed-wastage, and the question whether the amount of fertile seed produced is sufficient to cover such wastage of dispersal and germination under competition; that is to say, in any indigenous plant seed must be produced in great profusion. A chance for long-continued survival is afforded to plants which have already attained a method of ready vegetative propagation, which will multiply individuals without affecting the race. Thus the Common' Elm and the Gray Poplar (Populus canescens), which flower freely, but do not produce fertile seed, may maintain their station practically indefinitely by copious growth of suckers. Other herbaceous perennials which flower but never fruit, of known introduction, may in virtue of an efficient rhizome-system, defy extirpation (Aristolochia Clematitis), or carry on indefinitely where not interfered with ( $V$ inca, Helleborus foetidus, Acorus); and this applies particularly to 'bulbous' plants as the Snowdrops, Crocus, and Narcissus (sp.) of garden-cultivation. All plants which fail to produce seed at all under natural conditions, are clearly of alien origin; since they could not have come to the country by the ordinary agencies of seeddispersal, except as individuals rather than as a race, and for these the case is so far clearly recognized." But the subject takes on a wider range, and the main principle may be approached from another standpoint.

Great Britain over a northward extension of some 600 miles presents a marked range of climatic dispersal. Many types are fully successful in cstablishing themselves by seed, as apparently 'indigenous' in the South, v. 12.

1 Thas Caesar recorded that neither Beech nor Fir grew in Britain (54 B. C.), De Bello Gall.,

2 Dunn (1905), Alien Flora of Great Britain. 
which are unknown in the wild state in the North (Beech, Hornbeam, Viscum), although they will grow if planted. That is to say, somewhere in Central England they are on the vcrge of their northern distribution; implying that under these conditions they are unable to mature in successive seasons enough seed to counterbalance the increasing wastage of natural selection; and thus the race tends to die out, although individuals may long continue. Any condition which will ease off this wastage will make all the difference in survival. Among such aids may be included :-

(I) The utilization of perennation-mechanism (bulbs, rhizomes, resting buds, etc.) which enables the individual to tide over an unfavourable season, and so have a new chance of seeding.

(2) The utilization of fruiting-years in a climate with increasingly short working-period, as the plant may produce abundant seed in one season, but practically none in others; a common phenomenon in indigenous trees (Apple, Oak, Pinus), the more marked as the plants are at their critical range (Beech, Hornbeam).

(3) Assistance in dispersal to new stations by alien animals, other than those naturally indigenous (sheep, pheasants), and equally artificially maintained, or present in larger numbers owing to human protection (cattle, rabbits), including also unconscious dispersal by alien man himself (on clothes, boots, cart-wheels, etc.).

(4) Above all the increased provision of unoccupied ground, in which seeds may germinate under greatly reduced competition with other plants, or without any at all. This case follows the effect of human agency in clearing the ground, the felling of the forest, the ploughing of arable land, the making of hedges, cuttings and ditches, or the habitual destruction of any adjacent plant-lifc.

That is to say, apart from any question of intentional importation, the occupation of a country by man eases the wastage-problems for a large number of plants on the verge of their distribution, and with this slight assistance they may go farther north than they would otherwise, or be kept alive in what must be really artificial surroundings. The case is the more exaggerated when such plants acquire some economic significance, and are intentionally planted and 'nursed', in order to reduce still further the wastage-factor. Thus Beech grows in Scotland when planted, and so does the Mistletoe, but they do not become established: so far, these plants are alien in the North, though classed as fully indigenous in the South. Wild plants of the south may pass with slight assistance to grow associated with man in Central England, though becoming rare casuals in the North, in cultivated or cleared ground, before they finally disappear. The qucstion as to whether a plant is marked as alien or not in the general British Flora, has little reference to the constitution of the flora of a small district; political terms being confused with geographical.

With a wider range, the same generalizations hold for the relation of Great Britain to Continental Europe and the warm Mediterranean Region. Common plants of the last, with similar human assistance,may extend to Central Europe, in association with man, as weeds; and these may pass similarly to the South of England as short-season summer-annuals in cultivated land, wholly incapable of existence in open competition with the indigenous flora; becoming increasingly casual farther north, until they meet a climate in which they either fail to mature seed in the short season, or in which even an enormous output of seed fails to meet the wastage. That is to say, freed from competition with other vegetation in unoccupied ground, the weeds of a warn climate may follow migrant man until they are cut down by factors which are climatic rather than biological. In this way, human 
migration brings with it a long series of unconsciously imported aliens as associated, rather than 'introduced' weeds of pasture and arable land, as also of waste-heaps and dung-heaps, which soon become the commonest types of the new flora, evicting the previous natives from those stations, as the conditions are the more divergent from those of the original formation.

Such importations may also come into direct competition with indigenous plants occupying similar stations; and thus representative species of the same general character, and derived from different districts, may be found in increasingly mixed association. For example, where three or more closely 'allied', or apparently similar types of one genus occupy the same sort of station, it is probable that two at least are aliens :-cf. the remarkable 'sets' of Thistles, Chenopods, Polygonums, Veronicas, Euphorbias, and Poppies of arable and waste ground. Much the same applies to the more definite introductions of man for food or economical purposes. The Wheat of Western Asia, cultivated as an annual, requires to be sown in the previous autumn, and runs out before reaching the North of Scotland. In Orkney the only cultivated cereals are Oats and the 4-rowed Barley (Bere), and this in late seasons may be only harvested by November.

Taking this long-continued northward drift of the plants of the Old World area from Post-Glacial times, it is evident that no plant of S. Europe is now ever likely to establish itself in open competition with indigenous flora, however much it may apparently succeed with only slight assistance, or in the milder climate of S. England by the sea, where frost is practically eliminated. Thus Sycamore comes up freely as a weed in the West of England, in garden-ground and underwoods, but less in natural woodland, and not freely in gardens, in the Oxford District. Veronica Toumefortii has established itself in all cultivated land, within the last hundred years, but only in competition with other Veronicas of the same alien type ( $V$. agrestis); as Crepis taraxacifolia, locally common in grassland, replaces other alien forms of Crepis (as C. biennis) ${ }^{1}$ in waste-places where unoccupied ground may be artificially provided.

From these standpoints aliens may be graded according to the degree and amount of assistance gained from human occupation of the land as:(I) Assisted (a), the case of plants just holding on at the limit of their dispersal area, with the slight unconscious help of man in providing denuded ground, or taking seeds (e.g. Clematis). (2) Assisted associates (aa), plants normally indigenous, but owing their great and special development to the increased area in which they find suitable conditions (Buttercups, Daisies, Dandelions). (3) Assisted associate aliens (aaa), plants accompanying man in distant migrations, now so common and abundant as to pass for indigenous (e.g. Chenopodium album, Polygonum Persicaria), not establishing in normal pasture, nor in woodland. (4) Assisted associate alien adventives (a.aa), including chance casuals, coming in at any time, found only in cultivated or waste ground, not establishing, and usually not found in the same spot in successive seasons. It is also obvious that no sharp line can be drawn between such grades, but the consideration of numerous special cases may be interesting on their own merits.

On the other hand, plants coming from a botanical district so remote that there is no chance of dispersal by natural agencies, may be able to compete with indigenous flora on their own ground, and even to become invasive. The remarkable case of Elodea, brought from Canada about 1842 , and long a pest in streams and ditches, shows what can be done in this direction, even by vegetative propagation alone, the introduction being a carpellary plant. ${ }^{2}$ Hence there is so far no reason why plants from the

1 Cf. Dunn (1905), Alien Flora of Great Britain, pp. 1 I 3, 149.

2 Weeping Willow, carpellary only (1;30); Populus serotina (1787), Lombardy Poplar (1758) staminate, are all also the product of a single introduced individual. 
New Zealand Alps and uplands, for cxample, once they have been given the initial assistance required to bring them, should not prove successful, and dominate the English Hills. ${ }^{1}$ It is, however, interesting to note that none of the modern introductions of the N. Temperate zone from Japan, N. America, and California, brought for timber or decorative effect, have gone beyond the condition of casual escapes (Aster, Solidago, Lrepinus, Aquilegia, Estholtizia, etc.), though Oenothera and Mimulus may be referred to as locally naturalized in the south and by the sea. Also one wonders what is wrong when the finest forest-trees of N. America and Canada (Thuya plicata, Cupressus Nootkatensis, Picea Sitchensis, Pseudotsuga and Sequoia) ${ }^{2}$ do not appear able to competc without assistance with the muchenduring strays of the British Flora. The intense vitality of many of the plants of the British Flora, on introduction to distant colonies, is a matter of general remark; and older, more isolated Floras (Australia, California, Oceanic Islands) are rapidly devastated by the introduction of the weeds of cultivation. ${ }^{3}$ These are not so much the plants of the wild woodland flora indigenous to Great Britain, as 'human associates' similarly introduced into this country from the entire continent of Europe and Western Asia, constituting the most familiar weeds of cultivation, and so maintained in human association over many thousand years. Little reliance can be placed on alleged cases of such plants being found 'truly wild' in any district once inhabited by man. Whcrever man goes, he picks up a few more such associates, which follow his cleared ground in cnormous profusion: where he can live, they can flourish, and by such unconscious assistance, opportunity may be given for the survival under these new conditions of new races of mutants, some of which may thus appear to gain additional strength, rendering them 'invasive' where previously they were held in check. British peoples, as essentially corn-associates, unconsciously select any plants which follow the same periodicity as that of the wheat-crop; and such plants in mass-cultivation, as weeds of a cultivated crop, admit a seed-output which may cover a wastage far in advance of that of local forms just holding their own under conditions of extreme competition. In a formation which has attained a certain degree of equilibrium, and is so far 'closed', the introduction of seeds of wholly new plants will be a disturbing factor, affecting the wastage of previous occupants. Only by direct experiment does one realize the amount of secd required to produce a few specimens of some admitted 'alien' in open competition with a cultivated crop; let alone to establish it in a closed woodland or pasture-formation. ${ }^{4}$

As previously indicated, human occupation of the Oxford district is traced back at least to the Wolvercote sandbank of the Third Terrace, at $250 \mathrm{ft}$. elevation. The flats of Port Meadow, at $\mathrm{x} 90 \mathrm{ft}$., indicate some $60 \mathrm{ft}$. of eroded valley; a process which may have taken 50,000-100,000 years. Palaeolithic

1 Journal of Botany (192r), p. 354, Colonization of Snowdon.

S Sequoia sempervirens (Redwood) is narrowly restricted to the sea-fog zone of the Pacific Slope, and other trees in less degree.

s Sinclair ( 1885 ), Indigenous Flowers of the Hawaiian Islands, Introduction : 'Forest-fires, animals, and agticulture, have so changed the islands, within the last fifty or sixty years, that one can now travel for miles, in some districts, without finding a single indigenous plant : the ground being wholly taken possession of by weeds, shrubs, and grasses, imported from various countries.'

Hooker recorded the last plant 'farthest Sonth', as a specimen of Capsella Bursa-pastoris, growing at the door of a deserted sealer's hit. For the Dandelion in British Columbia, cf. Journal of l3otany, 1922, p. 274: also Thomson, 1922, Natnralization of Plants and Animals in New Zealand.

4 An arable field adjacent to Bagley Wood, with an aggregate flora of 102 species (including the boundary hedges), gave 73 forms on ground prepared by steam-plongh for the wheat-crop. Of these, some 50 were undoubted aliens of the nature of human associntes, or assisted types of the indigenous flora whose status is still donbtful. Although only separated from a woodland-clearing by an open gate-space and cart-track, but half a dozen of these last were found inside the wood, as feeble stray's for a distance of $20-30$ yds. 
man was solely dependent on the natural products of the district; and life is not possible in such a North Temperate climate without the essentials of fire and a knife. A fire can be built of twigs and branches snapped by hand, but wattle-huts and basket-work required knives in the form of flaked flints from the Chalk. With these it was possible to cut willows for wattle and basket-work, as well as staves and weapon-handles. The two-edged flint-scraper is the homologue of the safety-razor blade of to-day, thrown away when the edge was gone. Such flaked flints, generally distributed in the Wolvercote Brick-earth, probably indicate an encampment with woodwork done on the spot. The Villow was the first associate of man, and to Palaeolithic man was undoubtedly the essential tree, only replaced in later times by the Oak, following the evolution of the iron axe.

Hazel-nuts and Blackberries in their season are the only natural foodproducts of the district; and thus Rubus, Corylus, and Salix become the first human associates, to an extent that suggests that some at least of the numerous forms of native Willow are 'alien', and that the great variety of 'indigenous' 'spccies' of Willow owes its origin to the introduction of new types with advancing waves of human immigration. ${ }^{1}$

To Neolithic man, still unable to cut up a big tree, other than by splitting it with flint wedges-though log-canoes can be dug out by fire, or a tree carefully felled by fire (as by the Maoris in 6 weeks) ${ }^{2}$ - the Willow remained the all-important tree for wattle and basket-work, passing on to the coppiceshoots of the Hazel. Sparganium ${ }^{3}$ ramosum of the swamp-area, gave the first

1 The story of the poet Pope raising the first English Weeping Willow from a basket brought from Spain is possibly a jocryphal; l'it any old crate of green withy stranded on a mud-bank will shoot and may take root. The first British Willows were the minute $S$. polaris and $S$. herbacca of cold climate, probably followed by the earliest Spring-flowering forms, $S$. caprea, with associated $S$. cinerea, and the bush $S$. aurito. The later May-flowering S. alba, S. fragilis, S. triandra, S. purpurea, as well as the economic S. viminalis (Osier) are naturalized aliens of long standing. It is interesting to note $S$. triandra flowering in August on the lenfy shoots of the current year.

Such mingled forms may conceivably occasionally intercross and set seed; but the seedling history is still largely unknown. Cf. the valuable 'Cricket Bat Willow', S. coerulea, only grown as a carpeliary plant. Elwes and Henry (19:3), p. $17^{6} 3$.

It is also jnteresting to recall the thousands of years during which the Blackberry has been dispersed by human agency over a small district, far more effectively than by the birds for whom the fruits were originally intended; again indefinitely assisting the propagation of mutants and possible bylrids of the many hypothetical 'species' of the modem batidologist.

2 The Maris of New Zealand, persisting to recent times as a race of Neolithic civilization with no wild or klomesticated cattle, and with no knowledge of any metal, yet physically and intellectually is capable as an ordinary Englishman, affords a clear idea of the possibilities of Neolithic man in prelistoric times. The Maori utilized every natural prodnct of the country to the utmost. A great Totara tree, felled by fire, would give a canoe to the maximum length of $\mathbf{I} 20 \mathrm{ft}$, and with such vessels they successfullynavigated the Pacific for 5,000 miles, and made land-fall without a compass.

These is little need to postulate land-connexion of Great Britain with the continent : the land was practically covered with forest; sea, and the river leading from the sea, formed the natural highway. The river was the general means of getting abont locally until the time of the Normans. A camp on the Third Terrace at Wolvercote, or on Wytham Hill, would hrve had the same value as might the Castle Mound in the time of the Dancs. A dng-out canoe, found under peat at Brigg (Lincolnshire, 1884 ), was made from a $\log$ of Oak, $48 \frac{1}{2} \mathrm{ft}$. long and $6 \mathrm{ft}$. diameter, without the nse of any metal; a finer trecthan any standing at the present day (cf. Elwes and Henry, 1907, p. 343).

s Sparganium leaves, cut and allowed to dry, but not to become brittle, make material almost as good for tying as liast, or Raffia of to-day, and were so used to recent times. They are still employed for rush-mats and haskets. For local industries by cottagers and gipsies, continuing most ancient practice, cf. Woods (1921), Rural Industries round Oxford : for hazel wattle-hurdles, rakes, brooms, split-willow hurdles, and split willow for basket-work (p. 94). Glyceria aquatica of the river, cut and used for thatching hay-ricks instead of straw, has been noted (1022).

'Traces of older Neolithic practices still remain: 'wattle and danb' for huts, of the hazel and willow of the woodland, with abundant Oxford and Kimeridge Clays, is replaced by "lath and plaster'; the lath of cheap imported Pinus sylvestris, and the clays and limestones burnt for bricks and mortar. River-gravels beaten into the daub gave a weather-proof face, and gravel with cement is still seen on modern villa-residences. Turves, as originally cut for roofing-purposes (Plot), are now devoted to making lawns; but the burut tile, or the cut slab of Stonesfield Slate, maintains the original shape. Local terrace-gravels afford an ideal material for garden-paths, as rough blocks of Coral Rag which may be dug out of the ground, as well as quarried, make excellent rockeries for calcicolous plants. Though deficient in good building-stone, the district carries a wide range of clays, sands, gravels, and in former times peat. 


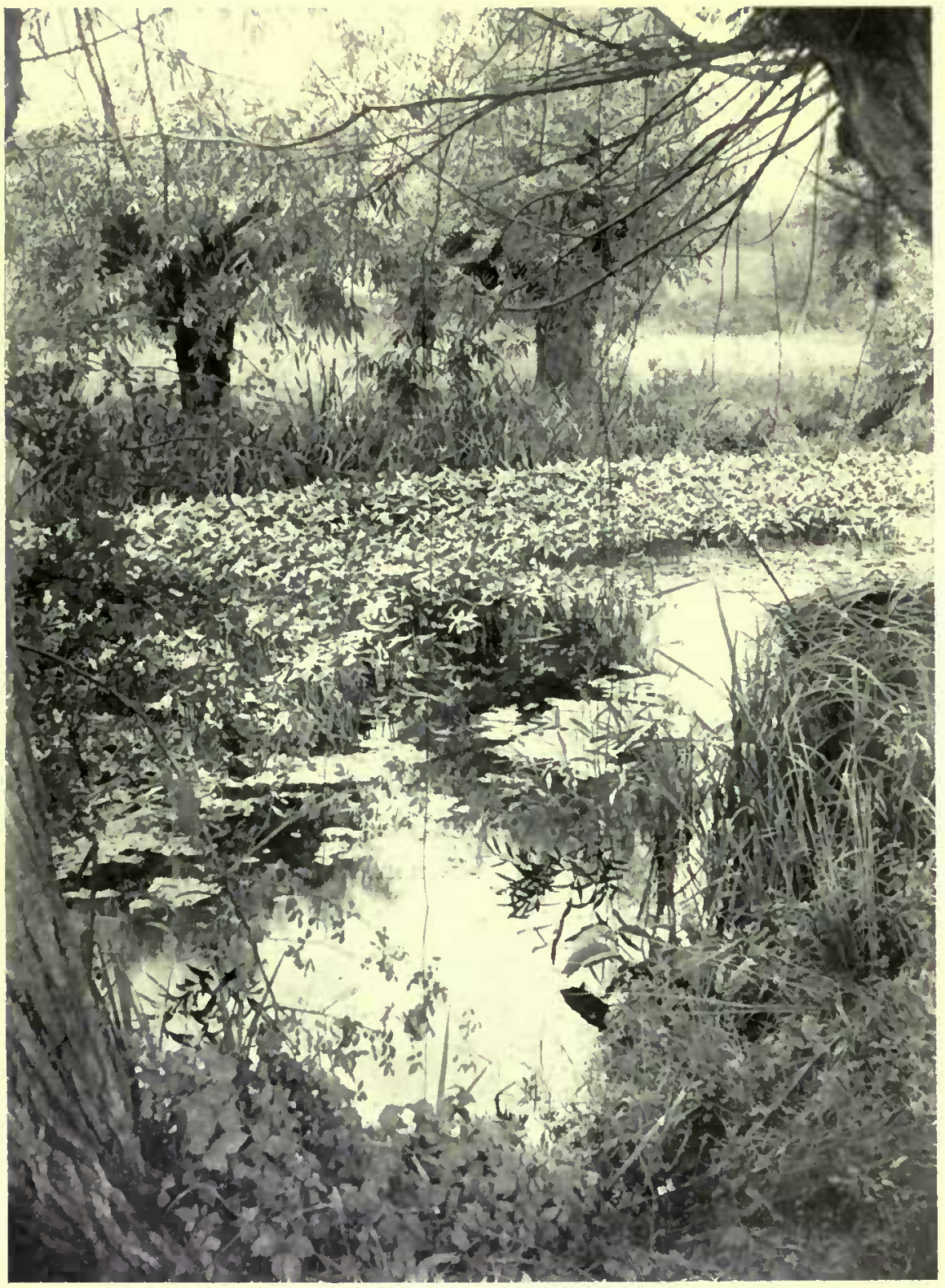

12. Ferry Hinksey Stream, Aug. I921. Pollard willow, Sagitlaria, \&4. 

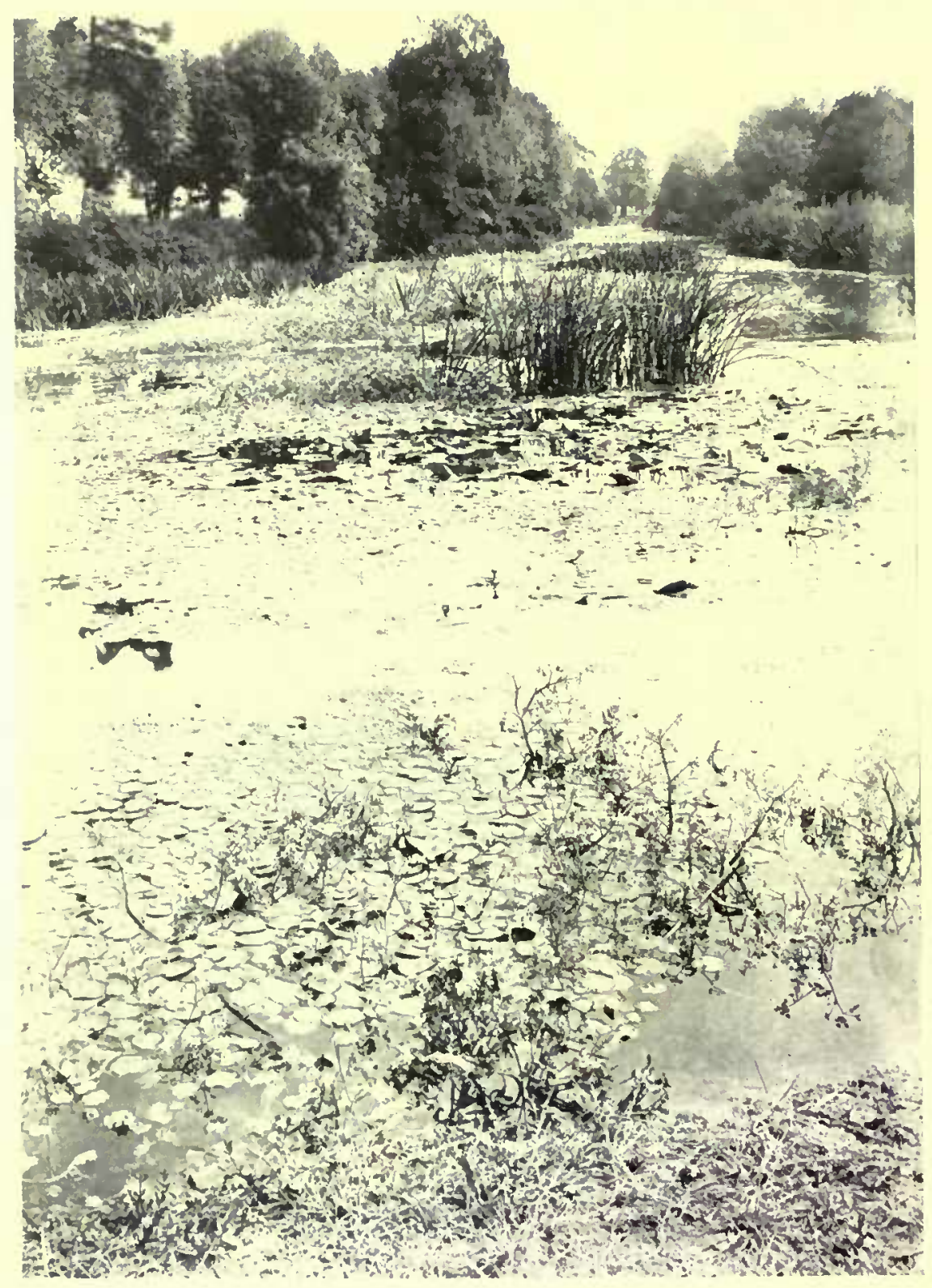

I3. Old River, Medley, July I92 I. Limnanthemum, Oenanthe fluciatilis, Nuphur, Scirfus lacustris, \&.c. 
textile, as ropes for tying (only replaced by the introduction of Tilia, as the 'Line-tree' for Bast-ropes giving efficient haulage material). The flexible stout basal shoots of the Hazel afforded the first bows; as the slender beautifully straight first year's shoots were the only local material from which an arrow could be trimmed with little difficulty by a flint-knife. There was still no sharper edge than a flaked flint: oyster-shells from the coast, or musselshells from the river, are only efficient for minor purposes. Ash might give a tougher shaft for tools and weapons, but required more trinming, as pollarded Yew ultimately replaced other staves for bows. The introduction of domesticated cattle brought with them pasture-grasses, and the weeds of waste-heaps from Central Europe. The addition of food-grains implies all the weeds of the corn-fields of Europe, due to imperfectly winnowed seed. No boat could come from Spain without bringing Chestnuts as common food, and ships from the Mediterranean probably brought a greater variety of plants than came by land; e. g., ship-transport of cattle implies some sort of hay or fodder with its sceds and weeds; the mild winter climate of S. England encourages the plants of S. Europe, which may fail in a more 'continental' winter of N. Germany. Only climatic conditions would prevent the establishment of seeds of the Date and Fig.

To this period may be probably referred the first introduction of the weeds of waste and foul ground around dwellings, as the establishment of many Chenopods, Polygonums, and Docks, which pass as indigenous, and are similarly associated with man on the main continent of Europe. 'The Sting Nettle (Urtica dioica), probably indigenous, as one of the last herbaceous representatives farthest north of a distinctly tropical family, has always been one of these assisted associates, primitively utilized as a textıle, before the introduction of Hemp (oriental) and Flax (N. African).

In later millennia, as indicated by the culture of the early British before the time of Julius Caesar, extensive connexion with the East, either by overland migration, or by means of navigation from the Mediterranean, is shown in economic plants of the time; though the connexion of the South Coast with the Midlands may have been but slight. The cultivation of forms of Wheat, the use of Woad (Isatis), and the cult of the Mistletoe-which as Viscum album replaces the Loranthus europaeus of the Evergreen Oaks (Quercus Ilex) of Thessaly-may preserve evidence of overland migrations to the North and West, as does the gradual dissemination of the use of bronze as a special type of alloy, and the use of horses. On the other hand, the Flax-plant of Egypt and N. Africa, as also the Saffron Crocus of the Eastern Mediterranean, may indicate commerce by sea. The cornfields of cereals from Western Asia still harbour the weeds of N. Africa; and the majority of 'naturalized' weeds, still unable to make good in woodland, were undoubtedly well-established long before the historical epoch. More efficient tools led to the introduction of soft-wooded trees, Salix alba, Populus nigra, and possibly Tilia and the Sycamore, as more easily worked.

The four centuries of the Roman occupation, with their increasing civilization, saw the Common Elm, Sycamore, Lime and Poplar well-established as timber-trees; and undoubtedly all the economic plants of S. Furope that would grow at all were in general cultivation. With seed-corn and hay from Gaul, Italy, and N. Africa, came further weeds of cultivation; and with the families of officials and soldiers retired on the land, garden-flowers, herbs, and vegetables of S. Europe and the East; a few of which may still survive as naturalized in the South, or as strays in the vicinity of Roman centres, in virtue of their successful perennation-stages. This applies more particularly to the decorative flowers of early spring (Snowdrops and the early Crocus of the Eastern Medilerranean, Leucojum vermum, L. aestivum, and all Narcissi beyond the common Daffodil): the Box (Buxus), utilized for its timber, and medicinal plants of established classical value, as described in Dioscorides (Paeonia, Helleborus, Aconitum), as also the 'Glastonbury Thorn'. Economic plants as Vitis, Ficus, and Onions were undoubtedly grown, but would soon die out 
(as individuals are incapable of propagation without assistance) when the connexion with Roman Gaul and Spain was broken at the English conquest.

Early English seeking land capable of growing corn, brought seed-corn from N. Germany, with associated weeds, as also fodder and hay of some sort with their cattle, with the probability of introducing any weeds of North Europe not previously imported from the South. As the forests were progressively cleared, the more useful trees as Willows and Poplars were increasingly planted, since these grow freely by the sides of streams and ditches from large sets and even poles, with no necessary knowledge of seedlings. Hazel-coppice, as longest surviving underwood, remained invaluable for nuts and wattle, and Oak as the longest-living standard tree became the timber of building-constructions; the oak-wood also valuable for acorns feeding hogs. Intercourse with Rome was resumed by the agency of the Church; the economic plants of S. Europe bcing continually re-introduced by patriotic pilgrims, and distributed from monastery gardens; as were also decorative or attractive and scented flowers (cf. Hollyliock, Myrtle, Laurel (Laurus nobitis), Lavender, Rosemary and Jasminum officinale), together with medicinal plants (as A ristolochia Clematitis surviving at Godstow Nunnery). Records of cultivation, somewhere in Britain, have little bearing on strictly local conditions; and many such plants may have been introduced independently at different times, and allowed to die out, as in the manner of present times, when the novelty is worn off. Vines have been grown in vineyards, but have been replaced by apple-orchards. Figs were always attractive, as also MIn]berries, and old plants are still growing at Oxford as attempts at introduction.

Definite record in Botanical Literature begins with Turner, ${ }^{2}$ and more particularly Gerard ${ }^{3}$ for the London District ( 5596 ). The latter shows a general knowledge of the plants of Europe in cultivation, and also several from North America (cf. Helianthus annuus); an attempt at the acclimatization of everything that could be grown in the open being made, as the expression of a growing scientific interest in new plants for their own sakes, rather than for their 'vertues'. 'The general dated list for introductions from this time onward is found in Aiton ( $\left.18 \mathrm{I}_{4}\right),{ }^{4}$ though plants marked $\mathrm{I}_{548}$ may have been cultivated for an indefunite period.

Special intcrest centres in the few vigorous types which have succeeded in making more recent impression on the lucal flora, and may be so far regarded as invasive:-

Elodea canadinsis (N. America, I $84_{2}^{2}$ ), in ditches, streams and river :

Crepis taraxacifolia (S. Europe), of grass-fields, spreading to waste places and good ground:

Veronica Tournefortii (SE. Europe, 1829), of arable fields, extending to roadsides and gardens :

Senecio squalidus (Medit. Region), in all waste ground, allotments and walls :

Goranium pyrenaicum (SW. Europe, I 762 ), in hedgerows and fields near houses:

Symphoricarpus racemosus (N. America, 1818 ), planted in hedges, and longcnduring:

as also the various trees in forest-cultivation, and the common and more conspicuous shrubs of gardens, parks, and hedgerows, as planted at some time, and now maintained as assisted associates of man, whether for economic or aesthetic purposes. Many such forms are now common objects of the district, as familiar as most of the forms of the indigenous flora, if not more so, and evcry one is expected to know something of them.

1 Cf. The 'Pocock Fig', Christ Church, 1636: Gunther, Oxford Gardens, 1912, p. 207: The Wild Fig (Ficus Carica) was germinated as a curiosity from Smyrna figs in the Botanic Garden, and bore its first crop of 'Profichi', 19ı. The Merton College Mulberry (Morus nigra) may date from 1605 .

2 Turner (15.51), Herball ; Ist edit. 1548 .

Gerard (1597), Herball; catalogue of the garden, 1596 .

- Aiton (1814), Epilome of the Second Edition of the Horizes Kewensis (Linnacan System). 
By the Romans, if not before, were introduced the Sweet Chestnut (Castanea sativa) for nuts and clean-growing timber which splits even better than Oak, Ulmus campesiris, probably from Spain, for timber, Sycamore, Lime and Poplar ( $P$. nigra and possibly $P$. canescens, as soft timber, light and not splintering, hence used for carts); also larger Willows (Salix alba, and probably S. fragilis, the Withy) as adapted for growing by the water-side, as also Osiers and associated forms for basket-work. Other trees of the Mediterranean region, and often Sycamore, Lime, Chestnut, will die out if not planted again; but Willows and Poplars are readily propagated by the most ignorant without any knowledge of seed-regeneration by putting in stakes (sets). Common Elm and Populus canescens are practically indestructible owing to active production of suckers. ${ }^{1}$

Before the printed records of the Sixteenth Century (1548) plants of S. Europe were grown as trees, food-plants and flowers, as the Cypress (Cupressus sempervirens), Pinus Pinea, Plane, Pink Almond and Cherry, Spruce, and Jasminum officinale, Myrtle and Daphne.

Sixteenth-century records include Laurustinus (Viburmum Timus), Lilac (Syringa vulgaris), Laburnum, Bay-Tree (Laurtus nobilis), Colutea arborescens (Bladder Senna), Walnut (Juglans regia), Quince (Cydonia zulgaris), Evergreen Oak (Quercus Ilex); and Yucca gloriosa from America with Thuya occidentalis (Arbor Vitae), also Pinus Pinaster.

The Seventeenth Century adds Cidrus Libani(1683); European trees as Abies pectinata (1603), Larix (1629), Acer platanoides (1683); North American trees, Liriodendron tulipifera (1663), Robinia Psendacacia (1640), with Rhus typhina (Sumach, 1629) and Ampelopsis hederacea (Virginian Creeper, 1629): Evergreens from the Mediterranean, Prumus Laurocerasus (Cherry Laurel, r629), Prunus lusitanica (Portugal Laurel, 1648), with garden shrubs, Lycium barbarum (1696) and Cratagus Pyracantha (1629). MIost striking of all the Horsechestnut (Aesculus Hippocastamum, from the Caucasus, 1629).

The Eighteenth Century does little more than continue the same series of decorative trees and shrubs for garden purposes, with a few of economic significance :-

Populus pyramidalis (1758), Populus serolina (1787), Pinus Strobus (Weymouth Pine) i 705 , A raucaria imbricata (Monkey Puzzle) I 796, Ailanthus glandulosa (1751), Magnolia grandiflora (1737), M. conspicua (1789), Buddleia globosa (1774), Aucuba japonica $\left(17839 \cdot 0^{7} 1876\right)$. Chimonanthus fragrans (1 776 ), Sophora japonica (1 753), T suga canadensis (1 736).

The Nineteenth Century, especially in the latier half, has seen the great influx of garden-shrubs of decorative value, as small gardens of the middle-class population become enormously more important and numerous than the large estates of the eighteenth century. While the great majority of older introductions are so well-established as to receive popular names, this does not apply to the more recent additions. The century also marks a great increase in Conifers, as evergreen trees and shrubs, more particularly from Japan and the Pacific Slope of N. America, many of which are hoped to improve forestcultivation. But with the addition of so many new forms, a certain amount of selection is unavoidable; older favourites are voted 'old-fashioned', and tend to be neglected for novelties which are not always an improvement. Among the more familiar shrubs of suburban gardens, cf. :-
Ampelopsis Veitchii (Hort.), Japan, 1868.
Berberis Aquifolium, N. America, 1823 .
Berberis Darwinii, S. Chili, 1849.
Buddleia variabilis (vars.) China, 1896.
Ceanothus azurus, Mexico, 1818 .

1 Populus cancsiens will scnd up suckers $50 \mathrm{yds}$. from the parent tree; its seedling history appears unknown. Populus nigra stands pollarding, but is now an uncommon tree, having been replaced in ecological station by the mutant Lombardy Poplar ( $P$. fastigiata), and the hybrid P. serotina (Black Italian Poplar), the finest tree locally. (Elwes and Henry, I913, p. 1803.). 
Ceanothus Veitchianus, California, 1859.

Choisya ternata, Nexico, 1825 .

Clematis Jackmanni (hybrids) $\mathbf{8 6 2}$.

Cotoneaster Simonsit, India, 1869.

Cydonia japonica. Japan, 1815 .

Fuon'mus japonicus, Japan, 1804 .

Fuchsie macrostema, hybrid Riccartoni, $183^{\circ}$.

Jasmintm nudiflorum, China, 1844 .

Leycesteria formosa, Himalya, 1824 .

Ligustrum japonicum, Japan, 1845 .

Ulearia Haastii, New Zealand, 1858.

Prunus Pissardi, Persia, I88 1 .

Prunus cerasifera, 1864, Myrobolan Plum, S. Europe.

Ribes sanguineum, NW. America, 1826.

Spiraea ariacfolia, NW. America, 1830.

Spiraca Lindleyana, Himalya, 1845.

Staphylea colchica, Caucasus, 1879 .

Symphoricarpus racemosus, N. America, 1818.

Veronica Trazersii, New Zealand, 1873 .

Wistaria sinensis, China, 1816.

Also as forest-tiees, largely grown as garden shrubs and park-specimens, all cvergreen :-

Abies nobilis, Oregon, $18 . \mathrm{I}$.

Cedrus Deodara, Himalya, 1831 .

Chamaecyparis Lawsoniana, California, 185.3 .

Chamaecyparis Nootkatensis, British Columbia, 1850.

Cupressus macrocarpa, Monterey, I $83^{8}$.

Pinus austriaca, Austria, 1835 .

Pinus insignis, Monterey, 1833 .

Pinus excelsa, Himalya, 1827 .

Pseudotsuga Douglasii, California, 1827 .

Sequoia semperzirens, California, i 846 .

Sequoia gigantea, California, 1853 .

Thuy' (Biola) oricnlalis, Japan, 1860.

Thuy gigantea, NIV. America, 1853 .

The casc of the introduced aliens of garden-cultivation, as herbaceous perennials and annuals, requires separate consideration: that of the alien trce and shrub is more significant as affecting the general appearance of the landscape and roadsides. As contrasted with the present abundance of introduced trees, flowering shrubs, and evergreen Conifers, the poverty of the older flora is pathetically illustrated by the early English practice of planting evergreens around the Churches, to give some appearance of life and greenery during the six long winter months-Yew and Ivy being the only available plants, with Holly for Christmas decoration, and the 'Palm' (Salix caprea $\sigma^{7}$ ) at Easter. Yet neither Yew nor Holly is now found growing locally cxcept where planted.

The same people who did this would show the greatest avidity in obtaining other plants from the Continent and South Europe, to ameliorate the wretched outlook of the clay countryside in cold, wet, and dark winter. Older English literature testifies to the affection felt for the carly Primrose, Violets, Cowslip, Pansy, and Cuckoo-Flowers, as well as the ubiquitous Buttercups, Daisies, and Dandelions of the pastures, and the Blackthorn, Hawthorn, Crab Applc, and Elder of the Waste.

The povcrty of the local aboriginal flora may be visualized by abstracting from the present landscape all the Common Elms, Huntingdon Elms Lombardy Poplars, Black Italian Poplars, the pollarded Willows, the Limes 


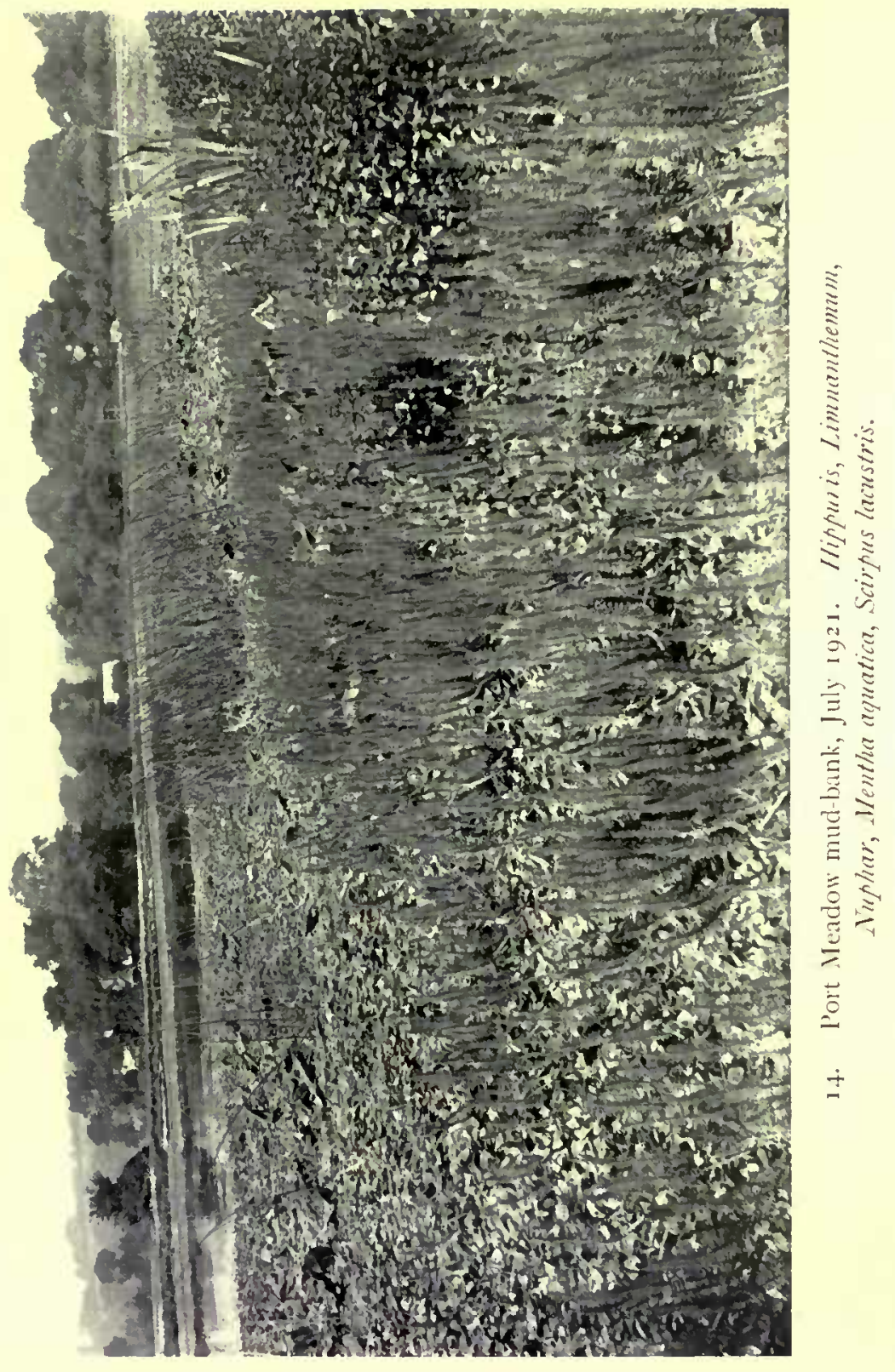




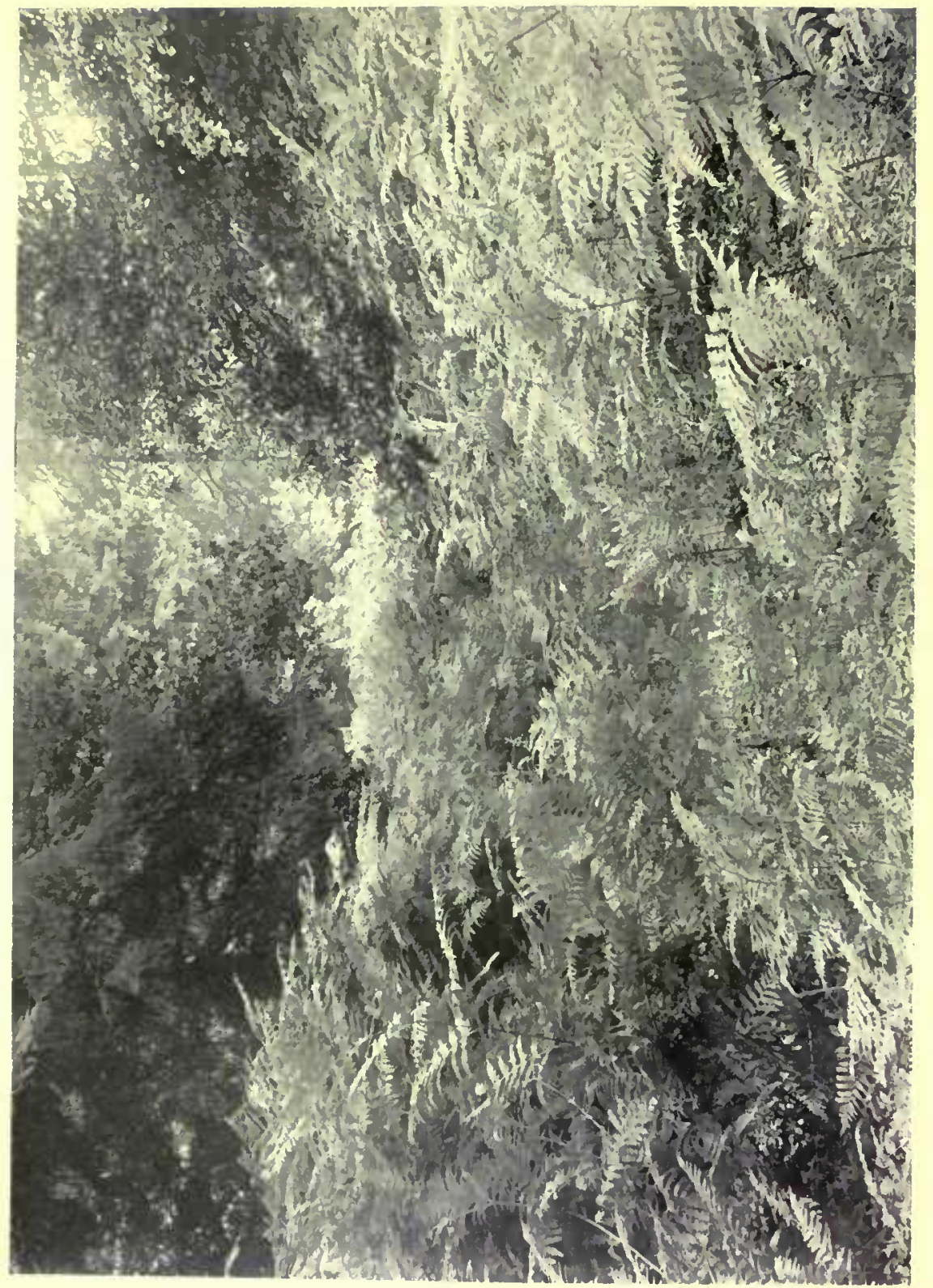


and Planes of the streets, all Conifers, Austrian Pine, Scots Pinc, Larch, Spruce, Cypress and Thuya of woodland and parkland, Sycamore, Horse Chestnut, Walnut, Sweet Chestnut, and probably Beech and Hornbeam.

The alien herbaceous flora includes the great majority of all the plants of occupied ground to the extent of 86 per cent. of the county arca, and is responsible for many pasture-grasses and weeds, as well as the associates of arable land, to a general estimate of nearly half the ecological flora. A few of these are of special local interest, as so familiar and long-established that they commonly pass as indigenous. Thus, Fritillaria Meleagris is wellcstablished in the wholly artificial alluvial pastures, and not elsewhere; though badly treated and picked on sight : Acorus Calamus (Sweet Flag) of the river holds its own on the edge of the bank by vegetative growth, but never fruits.

English gardens, ${ }^{1}$ instead of being filled with simples and a few decora. tive flowers, become the repositories of exotic forms from all parts of the world, their mutants, hybrids, and teratological phenomena, more particularly in the form of 'Florists' flowers'," as the apotheosis of the alien, assisted and selected by man, in a wholly artificial and arbitrary manner, not invariably directed by the best taste, perception of form, or colour-sense, and usually entirely ignoring the meaning, function, and evolution of the floral and reproductive mechanism. Before these the indigenous flora shrinks as an assemblage of weeds, on no account to be tolerated inside the garden-walls, except in the form of turf. Where the last interest of such forms centres in the manner in which they may be Mendelized, or inter-crossed to give still more puzzling freaks, one may still turn with relief to the honest frecfighters of the wild, knowing the great strength such plants have in reserve, and the rapid and devastating manner in which they would return once the hand of man were relaxed. The best gardens are only measured in liundreds of years, the wild flora in hundreds of thousands, the scope of Modern Botany takes into account many hundreds of millions.

1 Amberst (1845), (iardening in England, pp. 59, 123.

Parkinson (1629), Paradisus Terrestris: The Garden of Pleasant Flowers.

Hesler $(1613)$, Hortus Eystettensis.

2 Nicholson, Dictionary of Gardening, 'Florists' Flowers'. 



\section{OXFORD BOTANICAL MEMOIRS}

Edited by A. H. CHURCH; N.A.

1. THE BUILDING OF AN AUTOTROPHIC FLAGELLATE, by A. H. ChuRch. I9I9. Pp. 27 (out of print).

2s. net.

2. GOSSYPIUM IN PRE-LINNAEAN LITERATURE, by H. J. DENHAM, M.A. 1919. Pp. 24, 4 text figs. 2s. net.

3. THALASSIOPHYTA AND THE SUBAER̈IAL TRANSMIGRATION, by A. H. Church. IgIg. Pp. 95. 3s. $6 d$. net.

4. ELEMENTARY NOTES ON STRUCTURAL BOTANY, by A. H. Church. I9I9. 12 Lecture-schedules. Pp. 27.

2s. net.

5. ELEMENTARY NOTES ON THE REPRODUCTION OF ANGIO. SPERMS, by A. H. С Hurch. 1919. Io Lecture-schedules. Pp. 24. 2s. net.

6. ON THE INTERPRETATION OF PHENOMENA OF PHYLLOTAXIS, by A. H. GHurch. 1920. Pp. 58 , 18 figs. 3s. $6 d$. net.

7. ELEMENTARY NOTES ON THE MORPHOLOGY OF FUNGI, by A. H. Church. 1920. I3 Lecture-schedules. Pp. 29 25. net.

8. ELEMENTARY NOTES ON CONIFERS, by A. H. CHURCH. 1920. Fifteen Lecture and Laboratory Schedules. Pp. 32. 2.s. net.

9. FORM-FACTORS IN CONIFERAE, by A. H. CHURCH. Ig2O. Arranged as Supplement to preceding. Pp. 28. 2s. net.

Io. THE SOMATIC ORGANIZATION OF THE PHAEOPHYCEAE; an Introduction to the Theory of the Plant-soma, by A. H. CHURCH. 1920. Pp. IIO.

5s. net.

II. ELEMENTARY NOTES ON THE SYSTEMATY OF ANGIOSPERMS, by A. H. CHuRch. 1921. Thirty-four Lecture and Laboratory Schedules, arranged as Introduction to the Study of Flowers. Pp. 7I. 3s. $6 d$. net.

12. INTRODUCTION TO THE SYSTEMATY OF INDIAN TREES, by A. H. Church. I921. Sixteen Lecture Schedules. Pp. 50. 2s. $6 d$. net. 


\section{OXFORD BOTANICAL MEMOIRS (contd.)}

Edited by A. H. CHURCH, M.A.

13. INTRODUCTION TO THE PLANT.LIFE OF THE OXFORD DISTRICT. Part I. General Review, by A. H. Снurch. Ig22. Pp. I03, I5 plates from photographs.

3s. $6 d$. net. 


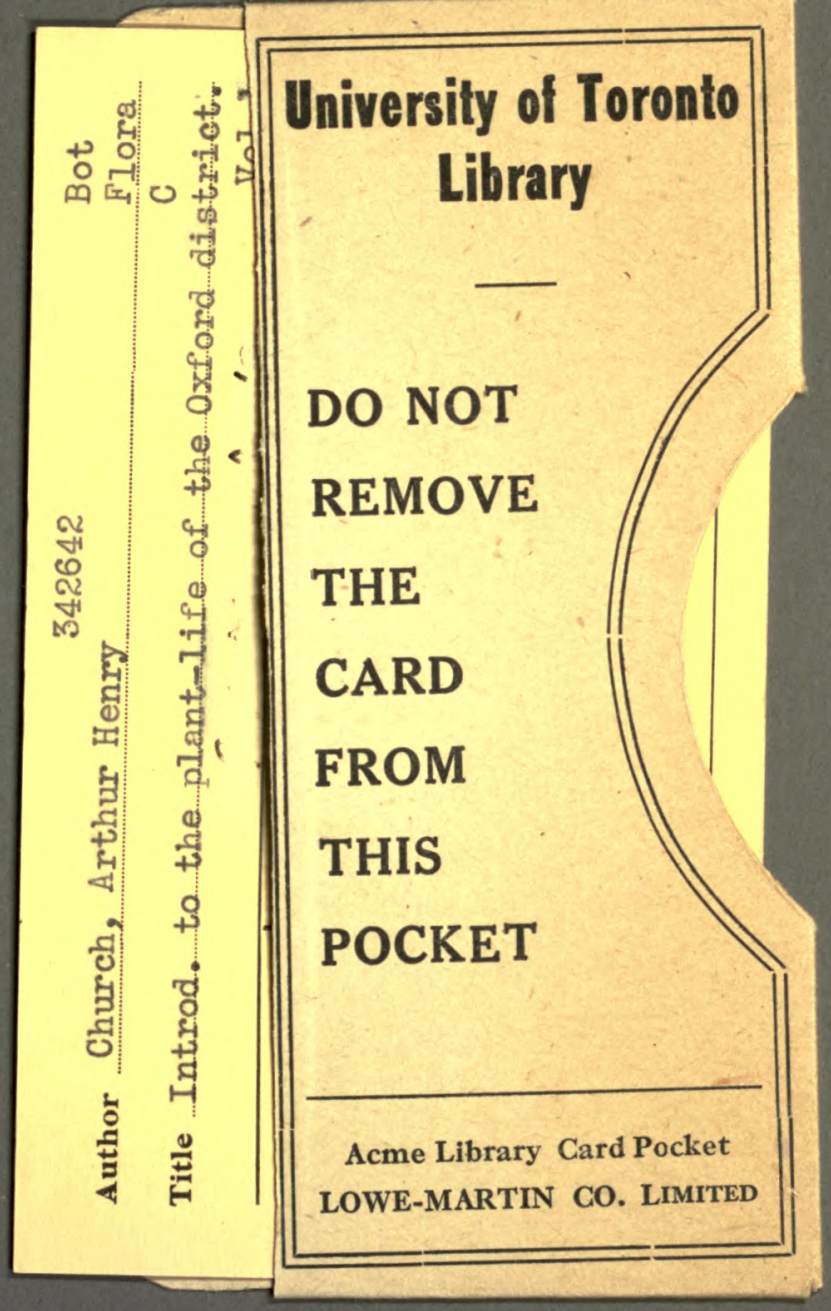


1.

\section{$+$}

